\title{
$7-2858$
}

\section{BIOLOGICAL SURVEYS ON THE SAVANNAH RIVER IN THE VICINITY OF THE SAVANNAH RIVER PLANT (1951-1976)}

ROBIN A. MATTHEWS
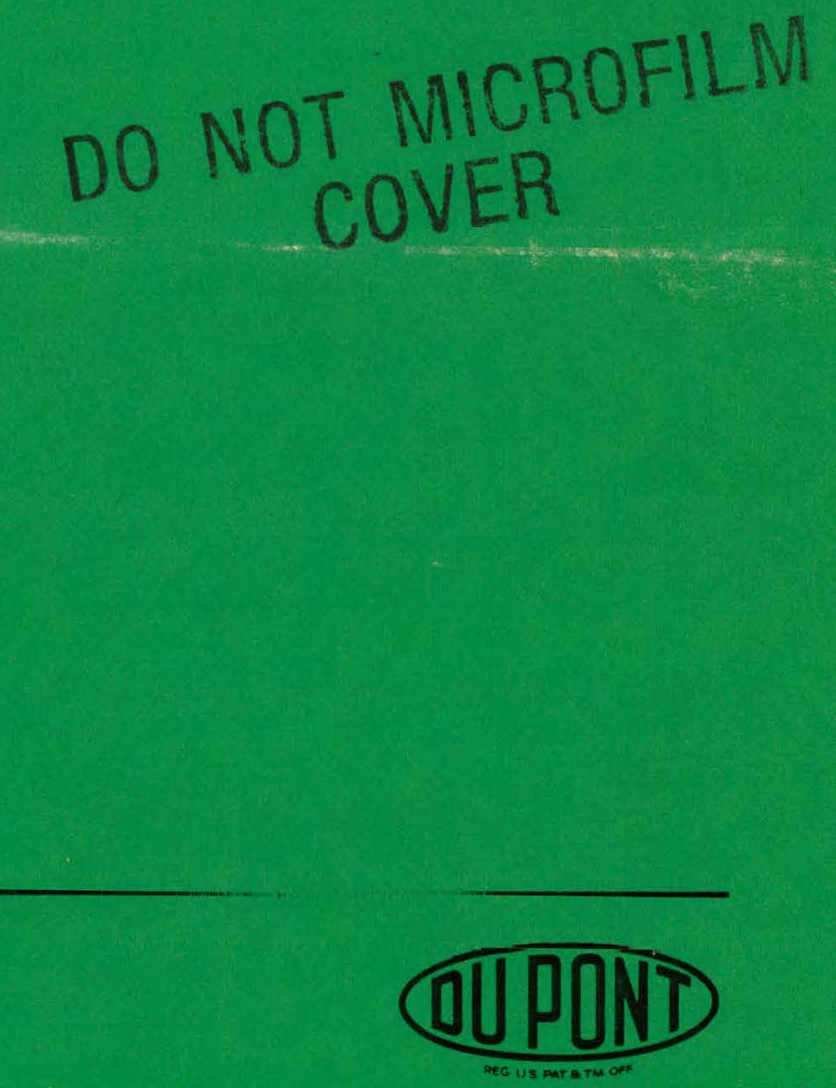

E. I. du Pont de Nemours \& Co. Savannah River Laboratory

Aiken, SC 29808 


\section{DISCLAIMER}

This report was prepared as an account of work sponsored by an agency of the United States Government. Neither the United States Government nor any agency Thereof, nor any of their employees, makes any warranty, express or implied, or assumes any legal liability or responsibility for the accuracy, completeness, or usefulness of any information, apparatus, product, or process disclosed, or represents that its use would not infringe privately owned rights. Reference herein to any specific commercial product, process, or service by trade name, trademark, manufacturer, or otherwise does not necessarily constitute or imply its endorsement, recommendation, or favoring by the United States Government or any agency thereof. The views and opinions of authors expressed herein do not necessarily state or reflect those of the United States Government or any agency thereof. 


\section{DISCLAIMER}

Portions of this document may be illegible in electronic image products. Images are produced from the best available original document. 



\section{BIOLOGICAL SURVEYS ON THE SAVANNAH RIVER IN THE VICINITY OF THE SAVANNAH RIVER PLANT (1951-1976)}

by

ROBIN A. MATTHEWS

Approved by:

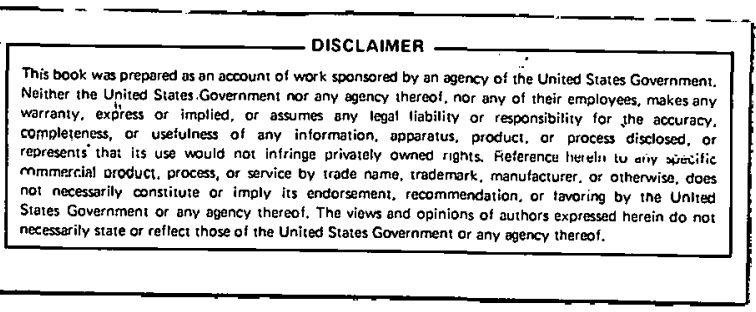

T. V. Crawford, Research Manager Environmental Sciences

Publication Date: April 1982

DP- -1531

DE82 013691

E. I. du Pont de Nemours \& Co. Savannah River Laboratory Aiken, SC 29808

PREPARED FOR THE U. S. DEPARTMENT OF ENERGY UNDER S.ONTRACT DE.ACO9-76SR00001 
The Savannah River Laboratory Data Base was created by J. E. Suich and J. H. Hightower, of the Savannah River Laboratory Computer Systems Division, and A. S. Dicks, of the Ecology Group. I would like to acknowledge their participation in that extensive project, and their many contributions to this report. Mike Odner, of the Academy of Natural Sciences of Philadelphia, has assisted in editing the computer data set. J. C. Corey, H. E. Mackey, $T$. V. Crawford and R. Patrick have reviewed this manuscript and provided éditorial comments. 


\section{THIS PAGE , \\ WAS INTENTIONALLY \\ LEFT BLANK}


COMMENTS

\author{
by \\ Dr. Ruth Patrick \\ Academy of Natural Sciences of Philadelphia \\ December 28, 1981
}

In 1951, the Academy of Natural Sciences of Philadelphia was contracted to initiate a long-term monitoring program to evaluate the effects of the Savannah River Plant on the Savannah River aquatic system. The purpose of this study was to establish conditions in the aquatic ecosystem:

(1) in the Savannah River immediately above the Savannah River Plant,

(2) just below various streams entering the Savannah River from the Savannah River Plant site, and

(3) in the Savannah River as it leaves the area of the Savannah River Plant.

The program was designed to monitor at frequent intervals the easily assayed conditions of the Savannah River using diatometers and quarterly studies. The more subtle changes in the river were to be determined by thorough surveys of the associations of the major kinds of aquatic life and the chemical and physical conditions of the river. These surveys were made at approximately four year intervals. In designing the program of study, there was no attempt to place study areas so as to detect the effects from any particular effluent produced by the Plant, but rather to detect major effects that might appear after a reasonable degree of mixing in the river.

This monitoring program has been continued up to the present, and provides a comprehensive data base covering 25 years of sampling. One of the great advantages of this program is that it has been conducted in basically the same way so that gradual changes over time can be assayed. The Savannah River Laboratory has computerized the Savannah River data, and they are available as described in this report. The Academy of Natural Sciences played a major role in making sure the computerized taxonomy was as correct as possible and consistent throughout the data set. One of the greatest problems in placing a large data base such as this one in a computer where it may be used for a long period of time is to make sure that there is a reliable taxonomic classification and the sources or authorities for this classification are clearly set forth. "In this work, the following publications and personal 
communications are the basis on which the taxonomic classifications were made.

Algae: We have discussed the classification of the algae with Dr. Paul Silva, Dr. Francis Drouet, and Dr. Charles W. Reimer. The general taxonomy of all groups except diatoms followed Bourrelly (1970), Silva (1960), and Drouet (1973). For diatoms Patrick and Reimer $(1966,1975)$ was used.

Protozoa: For general organization we have used Kudo (1966), Jahn and Jahn (1949), Schaeffer (1926), Kahl (1930-34). Pascher (1927), Pascher and Lammermann (1912, 1914), and Page (1976). For general classification we have asked the advice of

Dr. John Cairns, Jr.

Invertebrates: For general discussion, particularly concerning species of mollusca, Dr. Samuel L. H. Fuller was consulted. For developing the classification, the following authorities were used: Porifera and Platyhelminthes - Pennak (1978); Nemertea - Pennak (1964) and Hyman (1951); Aschelminthea Hyman (1951) and Edmondson (1959); Tardigrada - Pennak (1978); Bryozoa - Rogick (1959); Annelida - Brinkhurst and Jamieson (1971), Sybil Parker (personal communication); Mollusca - Taylor and Sohl (1962), Newell (1965), Turner (personal comunication); Mollusca - Taylor and Sohl (1962), Newell (1965), Turner (personal communication); Arthropoda - Pennak (1978).

Insects: The greatest responsibility has rested on

Dr. Selwyn S. Roback, who has utilized many references in developing his opinions.

Fish: Our principal consultants have been Dr. James E. Bohlke and Dr. William Smith-Vaniz. This classification has largely depended on Dahlberger and Scott (1971). However, Bailey et al. (1979) has in some cases been used.

No attempt has been made by the Savannah River Laboratory to interpret the data. However, the Academy of Natural Sciences of Philadelphia has published several reports on these data and intends to publish several more papers utilizing these data now that they have been computerized. The publications to date are listed in the reference section of this report.

There have been 16 comprehensive river surveys from 1951-1976. In addition to the comprehensive river surveys, diatometers were installed in the river in 1953, and have been used continuously up to the present. The types of data collected from these diatometers have differed somewhat over time. In the beginning, four quarterly detailed readings, which involved the construction of truncated normal curves, were carried out four 
times a year. Every two weeks, rough readings were made in which slides were scanned to see if there was any definite change in the species present; however, these taxonomic identifications were not very thorough, and are not included here. This report includes the data from the comprehensive river surveys and the quarterly detailed diatometer readings. The diatometer data represent a semi-continuous biomonitoring program that may be used to supplement the major survey data.

Representative specimens of all species collected on all the comprehensive surveys were placed in the permanent collections of the Academy of Natural Sciences of Philadelphia. This enables anyone in the future to bring together the species that were associated at any point in time during the studies. It also enables the Academy to revalidate identifications of the diatoms from the diatometer collection, which were also placed in the permanent collections in the Academy of Natural Sciences of Philadelphia diatom herbaria.

Some of the most important considerations in carrying out a baseline study are to make sure the locations of the sampling stations are correctly selected. In the Savannah River, several factors had to be carefully considered in the location of such stations. The first requirement is to place the stations so that they show the impacts of the operations of the Savannah River Plant on the Savannah River, and to separate these changes from upstream effects. For this reason, the upstream station had to be located in an area close to, but above, potential outfalls, but also in an area where mixing was fairly complete in the river.

It was essential to have similar current patterns in the areas of study, which in turn produce similar shoaling areas and cutting areas. There must also be areas in which sediments are eroding and sediments are being deposited. In the Savannah River, the bed is unconsolidated sand. The best habitats for aquatic organisms are in the shallow waters, on floating debris, or on solid substrates that are impinged in the river bed. In the shallow water, the river bed consisted mostly of sand or sands with mud and silt. For these reasons, one would like to have a point bar at each of the river stations. Unfortunately, this was not possible at the two upper stations (Stations 1 and 3 ). However, near these stations, revetments had been placed in the river by the $U$. S. Corps of Engineers prior to the time of the first surveys." These areas contained habitats similar to those of a point bar. Around each one of these revetments there were depositing and eroding areas, and areas of shallow water which would make seining of fish easy. We, therefore, located the two upper stations (Stations 1 and 3 ) in the vicinity of revetments and the two lower stations (Stations 5 and 6 ) to include point bars. 
It is also important to have the original location of the stations in regards to East-West or North-South directions as similar as possible in order that the exposure of the banks to light will be similar. One also has to be sure that similar amounts of debris are present in each of the stations because the dead trees and branches provide an excellent habitat for aquatic life. The dredging of the river by the Corps of Engineers, which removed some debris, definitely affected the availability of habitats and the population of sizes and various species.

The river communities and populations were sampled qualitatively from a wide variety of habitats. Experience has shown that if one collects from one to two hours after one obtains the last new entity in insects, macro-invertebrates and fish, one has collected the species that were established in the area. For microorganisms such as protozoa and algae, all available habitats must be sampled. As a result, it takes at least one day, and often two days, to sample any area. Separate species lists were developed for algae, protozoa, macroinvertebrates, insects, and fish. Appendices $A$ and $B$ provide a summary of the biological and chemical data available for each of the major surveys. Appendix B.L sumarizes the survey data, averaged for each station by survey number. Appendix B. 3 includes the diatometer data derived from the studies in which the truncated normal curve model of the community was constructed.

When one examines the numbers of species present, one must remember that there are many environmental factors that affect the presence of species. Also important is one's ability to collect the species, i.e. high water as opposed to low flow. Furthermore, species react in aquatic systems according to the total stress from various causes, as long as one stress is not acute, and causes death. We have found that, in any given area, a 33 percent change in species numbers from the average for that area is natural, and only when the change is greater than 50 percent is severe perturbation indicated. Stated another way, generally, the natural functions of the transfer of nutrients in the food web can be maintained so long as 66 percent of the natural pattern of diversity of the various major groups is maintained. This applies to those groups in which there are many species. For these reasons, we have considered as separate groups, the algae, the protozoa, the invertebrates other than insects, the insects, and the fish.

Many things have happened over time in the Savannah River and some of these changes seem to be correlated with shifts in numbers of species in some of the groups. The algal flora in the river is dominated by diatoms. Station 6 has had the most radical shifts in numbers of diatom species. At all stations since 1968, there has been a small but consistent reduction in numbers of species. This decrease in species numbers seems to be correlated with the increase in chlorides in the river as evidenced by the chemical 
analyses. These changes were correlated with the start-up of certain industries known to have chlorides in their effluents. Because the diatom species found in the Savannah River are typically soft water (low conductivity) species, one might expect such correlations. In the other groups of algae, which have very few species, more detailed studies are needed to interpret changes.

In the protozoa there seems to have been an increase in flagellates since 1972 in most stations that seems to be correlated with an increase in ammonia concentrations in the river. Likewise, the increase in ciliates seems to be correlated with increases in bacteria in the river.

of the invertebrates other than insects, the mollusca were the only ones represented by a fairly diverse fauna. They show an irregular pattern, but seem to be more numerous since the building of Clarks Hill Dam, which has resulted in less fluctuation of water levels. Much more study is needed of these invertebrates to understand their patterns.

The more sensitive insects, such as stoneflies, have tended to be fewer in the surveys since 1955-56, and these changes may be correlated with the increased pollution load in the river. More study is needed to support or refute this statement. There was evidence that dredging activities, which varied in intensity at the different stations in different years, influenced the numbers of caddisflies, which are filter-feeders. These correlations were noted in the reports of the Academy of Natural Sciences of Philadelphia.

of the fish, the suckers, minnows, sunfish and perch were more numerous as to species numbers in the river. These seemed to have increased since the building of Clarks Hill Dam. However, it must be pointed out that restricted use of rotenone was not used in the first few survery, and has been used since then. This method allows retrieval of some species not otherwise caught.

In conclusion, it should be stated that these observations can be refined by more careful study of the data. The Academy of Natural Sciences of Philadelphia plans to continue analyzing these data in order to reevaluate and continue developing their conclusions. 


\section{PAGES 1 to 2 WERE INTENTIONALLY LEFT BLANK}


In 1951, the Academy of Natural Sciences of Philadelphia was contracted by the Savannah River Plant to initiate a long-term monitoring program in the Savannah River. The purpose of this program was to determine the effect of the Savannah River Plant on the Savannah River aquatic ecosystem. The data from this monitoring program have been computerized by the Savannah River Laboratory, and are summarized in this report.

During the period from 1951 - 1976, 16 major surveys were conducted by the Academy in the Savannah River. Water chemistry analyses were made, and all major biological communities were sampled qualitatively during the spring and fall of each survey year. In addition, quantitative diatom data have been collected quarterly since 1953. Major changes in the Savannah River basin; in the Savannah River Plant's activities, and in the Academy sampling patterns are discussed to provide a historical overview of the biomonitoring program. Appendices to the data report include a complete taxonomic listing of species collected from the Savannah River, and summaries of the entire biological and physicochemical data base. 


\section{THIS PAGE WAS INTENTIONALLY LEFT BLANK}


Comments by Dr. Ruth Patrick iii

Abstract 3

Introduction 10

Personnel 11

Savannah River Basin History 17

Savannah River Plant Activities 28

Chronology of Surveys and Studies 39

Sampling Stations 39

Methods 53

Scope of the Savannah River Laboratory Data Base 57

References $\quad 64$

Appendix A

Savannah River Taxonomic Accession List 67

A. 1

Algae 68

A. 2

Fishes 93

A. 3 .

Macro-invertebrates 98

A. 4

Protozoa 125

A. 5

Unidentified Taxa 148 
CONTENTS (Contd)

Appendix B

Sample Data Presentations 150

B. 1

Savannah River Taxonomic Data Summary 151

B. 2

Sample Presence/Absence Data for Two Diatom Species 188

B. 3

Sample Diatometer Data 189

B. 4

Savannah River Water Chemistry Summary 199

Appendix C

Savannah River Flow and Temperature Data 224

C. 1

Savannah River Flow and Temperature Data at Augusta (A)

or Jackson (J) 225

C. 2

Savannah River Daily Flow at Augusta during the Academy

of Natural Sciences of Philadelphia Surveys 228 
Table Title

Page

1 Minimum, Maximum, and Average Flows of the

Savannah River (Measured at Augusta)

- 2 Stream Use Classification of the Savannah River (1974)

3 Partial List of the Savannah River Pollution

Sources from the Augusta Area

4 Partial List of the Savannah River Pollution

Sources from the North Augusta and Aiken County Areas

5 Savannah River Dredging Activities, 1964 through 1974 (Partial Listing)

6 Radioactivity in Savannah River Water (1975)

7 Comparison of Changes in Savannah River Water Quality with Drinking Water Standards (1.975)

8 Pesticides Analyzed by USGS in Savannah River

Sediment and Water Samples (1975)

9 Fecal Coliform Bacteria Measurements (1975)

10. Startup and Stand-by Dates of the Savamuls River Plant Reactors

11 River Temperatures Near Four Mile Creek (Measured 4/10/72)

12 River Temperatures Near Steel Creek (Measured 4/13/72)

13 Maximum Temperature Increases Caused by the Savannah River Plant in the Savannah River

14 Chronology of Surveys Conducted by the Academy of Natural Sciences of Philadelphia on the Savannah River (1951-1976) 
Table Title

15 Descriptive Summary of Stations Used by the Academy of Natural Sciences of Philadelphia on the Savannah River

16 Summary of Methods Used for Physical, Chemical, and Bacteriological Analyses of Savannah River Water Samples

17 Taxonomic Hierarchy used for the Classification of the Savannah River Biological Data 
1 Counties Included Within the Savannah River

Drainage Basin

2 Major Tributaries and Physiographic Regions

Included in the Savannah River. Drainage Basins

3. Location of the Savannah River Plant in the

Savannah River Drainage Basin

4 The Savannah River Plant Site

5. Survey Stations Used by the Academy of Natural Sciences of Philadelphia on the Savannah River $(1951 \div 1976)$

Field Sketch of Station 1

Field Sketch. of Station 3

Field Sketch of Original Station 5

Field Sketch of Relocated Station 5

Field Sketch of Station 6 


\section{CHAPTER I. INTRODUCTION}

The Savannah River Plant is a U. S. Department of Energy facility operated by E. I. du Pont de Nemours and Company. It is designed to produce nuclear materials for national defense. The Savannah River Plant is located about 25 miles southeast of Augusta, Georgia, along the South Carolina side of the Savannah River. Construction of the Savannah River Plant began in February, 1951, and involved a peak construction force of 39,000 workers. The first production reactor began operations on December 28, 1953.

In 1951, the Academy of Natural Sciences of Philadelphia was contracted to initiate a long-term monitoring program to evaluate the effects of the Savannah River Plant on the Savannah River aquatic system. This monitoring program has been continued up to the present, and provides a comprehensive data base covering more than 25 years of sampling. The Savannah River data collected from 1951 through 1976 have been computerized by the Savannah River Laboratory, and are available as described in this report. No attempt has been made by the Savannah River Laboratory to interpret the data; however, the Academy of Natural Sciences of Philadelphia has published a number of data interpretations. $1-11$

This report can be divided into two sections. The abstract and Chapters I through IX describe the Savannah River Plant and the Academy's surveys in detail. These chapters also provide a historical review of the Savannah River Basin from 1951 - 1976, and out line. some of the changes that have occurred in the Savannah River Plant area that may have influenced the survey. The second section consists of Appendices A, B and $C$, which list the Savannah River Taxonomy and summarize much of the physical, chemical, and biological data from the Savannah River. These Appendices are included to show some examples of computer formats available for analyzing the data. 
CHAPTER II. PERSONNEL

During the course of this study, Dr. Patrick has been responsible for the design of the studies and for the integration of results as set forth in the various Academy reports.

Members of the Academy of Natural Sciences, Philadelphia, who participated in the Savannah River surveys include the following individua 1s:

\section{Survey 1 (June 25 - July 14, 1951)}

John Cairns, Jr. Thomas Dolan, IV. Harold W. Harry John Lattin Ruth Patrick Wilbur E. Wade John H. Wallace John M. Ward Charles B. Wurtz
Protozoologist

Entomologist

Invertebrate Zoologist

Entomologist

Director of Survey

Algologist

Algologist

Chemist and Bacteriologist

Invertebrate Zoologist

Survey 2 (Oct. 15 - Nov. 31, 1951)

Fairie: Lyn Carter

Thomas Dolan

Sidney Kantor

George W. McCammon

Ruth Patrick

Selwyn S. Roback

John H. Wallace

Charles B. Wurtz
Chemist and Bacteriologist

Entomologist

Protozoologist

Ichthyologist

Director of Survey and Algologist

Entomologist

Algologist

Invertebrate Znolngist.

\section{Survey $3(\operatorname{Jan} .9-31,1952)$}

Fairie Lyn Carter Thomas Dolan, IV. George W. McCammon Ruth Patrick Selwyn S. Roback John H. Wallace Ralph Wichterman Charles B. Wurtz
Chemist and Bacteriologist

Entomologist

Ichthyologist

Director of Survey and Algologist

Entumulugist Algologist Protozoologist

Invertebrate Zoologist 
Survey 4(May 5-22, 1952)

Fairie Lyn Carter

Thomas Dolan, IV

George W. McCammon

Ruth Patrick

Selwyn S. Roback

John B. Wallace

Ralph Wichterman

Charles B. Wurtz
Chemist and Bacteriologist

Entomologist

Ichthyologist

Director of Survey and Algologist

Entomologist

Algologist

Protozoologist

Invertebrate Zoologist

Survey 5 (Aug. 15-30, 1954)

Frederick A. Aldrich

John Cairns, Jr.

Harold de Ropp

Ruth Patrick

Selwyn S. Roback

John H. Wallace
Invertebrate Zoologist

Protozoologist

Field Assistant

Director of Survey

Entomo logist

Algologist

Survey 6 (Aug. 24 - Sept. 7, 1955)

Frederick A. Aldrich

John Cairns, Jr.

Robert W. Haywood, III

James Jacobs

Ruth Patrick

Charles W. Reimer

Selwyn S. Roback

Yvonne H. Swabey
Invertebrate Zoologist

Protozoologist, Field Director

Field Assistant

Field Assistant

Director of Survey

Algologist

Entomologist

Chemist and Bacteriologist

\section{Survey 7 (May $6-22,1956)$}

Frederick A. Aldrich

John Cairns, Jr.

Robert R. Grant, Jr.

Ruth Patrick

Charles W. Reimer

Selwyn S. Roback

Yvonne H. Swabey
Invertebrate Zoologist

Protozoologist, Field Director

Field Assistant

Director of Survey

Algologist

Entomologist

Chemist and Bacteriologist 
Survey 8 (May 23 - June 4, 1960)

John M. Bates

John Cairns, Jr.

Phillip J. Halicki

Nancy E. Hess

Ruth Patrick

Selwyn S. Roback
Invertebrate Zoologist

Protozoologist, Project Supervisor Algologist

Chemist and Bacteriologist

Director of Survey

Entomologist

Survey 9 (Aug. 31 - Sept. 15, 1960)

John M. Bates

John Cairns, Jr.

Nancy E. Hes s

Thomas Lloyd

Sams on McDowe 11

Ruth Patrick

Charles Reimer

Selwyn S. Roback
Invertebrate Zoologist

Project Supervisor

Chemist and Bacteriologist

Field Assistant

Protozoologist

Director of Survey

Algologist

Entomologist

\section{Survey 10 (May 30 - June 8, 1965)}

John M. Bates

John Cairns, Jr.

Neal Foster

Robert R. Grant, Jr.

Jules J. Loos

Ruth Patrick

Selwyn S. Roback
Invertebrate Zoologist

Protozoologist

Ichthyologist

Algologist and Field Supervisor

Field Assistant

Director of Survey

Entomologist

Survey 11 (Sept. $21-30,1965$ )

John M. Bates

John Cairns, Jr.

Neal Foster

C. W. Hart, Jr.

Jules J. Loos

Sams on McDowe 11

Nicholas Nitti

Ruth Patrick

Charles Reimer

Selwyn S. Roback
Invertebrate Zoologist

Protozoologist

Ichthyologist

Invertebrate Zoologist and

Field Supervisor

Field Assistant

Protozoologist

Chemist and Bacteriologist

Director of Survey

Algologist

Entomologist 
Survey 12 (May 27 - June 5, 1968)

Robert R. Grant, Jr.

Robert W. Haug

Irwin R. Isquith

Edward Jankowski

Gerald J. Lauer

Ruth Patrick

Jay W. Richardson

Selwyn S. Roback
Algologist and Field Supervisor

Chemist

Protozoologist

Field Assistant

Ichthyologist

Director of Survey

Invertebrate Zoologist

Entomologist

Survey 13 (Aug. 24 - Sept. 2, 1968)

Robert R. Grant, Jr.

Robert $W$. Haug

Irwin R. Isquith

Edward Jankowski

Gerald J. Lauer

Ruth Patrick

Jay W. Richardson
Algologist and Field Supervisor Chemist

Protozoologist

Field Assistant

Ichthyologist

Director of Survey

Invertebrate Zoologist and

Entomologist

Survey 14 (May 22 - June 2, 1972)

Martin DeGraw

Neal Foster

Samue 1 Fuller

Robert R. Grant, Jr.

Edward Jankowski

Ruth Patrick

Jay W. Richardson

Jesse Steelman

William Yongue
Field Assistant

Ichthyologist

Invertebrate Zoologist

Phycologist and Field Supervisor

Field Assistant

Director of Survey

Entomologist

Chemist

Protozoologist

Survey 15 (Sept. 13 - Oct. 1, 1972)

Neal Foster

Samuel Fuller

Robert R. Grant, Jr.

Edward Jankowski

Joy Morrill

Ruth Patrick

Jay W. Richardson

Selryn Roback

Jesse Steelman

William Yongue
Ichthyologist

Invertebrate Zoologist

Field Supervisor

Field Assistant

Phycologist

Director of Survey

Entomologist

Entomologist

Chemist

Protozoologist 
Survey 16 (Aug. 10-16, 1976)

Jules Loos

Samuel Fuller

Clyde Goulden

Robert R. Grant, Jr.

Edward Jankowski

Jay W. Richardson

Larry Lyons

Irwin Isquith

Kenneth Johnson

James Strickland
Ichthyologist

Invertebrate Zoologist

Director of Survey

Phycologist and Field Supervisor

Field Assistant

Entomologist

Chemist

Protozoologist

Field Assistant

Field Assistant

The following authorities assisted in identification of a portion of the specimens collected:

\section{Entomologists}

Leonora K. Gloyd

Illinois Natural. History Survey

Urbana, Illinois

(Surveys 1-4)

\section{John Hans on}

Department of Entomology

University of Massachusetts

Amherst., Massachusetts

(Surveys, 1-4)

Charles Hodge, IV

Chestnut Hill

Pennsy lvania

(Surveys 1-15)

Milton W. Sanderson

Illinois Natural History Survey

Urbana, Illino is

(Surveys 1-4)
John C. Lutz

American Entomological Societies

Philadelphia, Pennsylvania

(Surveys 1-9)

Selwyn Roback

Division of Limnology

Academy of Natural Sciences

Philadelphia, Pennsylvania

(Survey 16)

Paul Spangler

Department of Entomology

Smithsonian Institution

Washington, DC

(Survey 16)

Minter J. Westpha1l, Jr. University of Florida Gainesville, Florida

(Surveys 1-16)

Jay R. Traver

University of Massachusetts

Amherst, Massachusetts

(Surveys 1-4) 


\section{Ichthyologist}

Reeve M. Bailey

University of Michigan

Ann Arbor, Michigan

(Surveys - 5-7)

James E. Bohlke

Academy of Natural Sciences

Philadelphia, Pennsylvania.

(Surveys 8-9)

Bruce B. Collette

Cornell University

Ithaca, New York

(Surveys 6-7)
Robert Kuehne

University of Michigan

Ann Arbor, Michigan

(Surveys 5-7)

Ernest J. Lachner

Smithsonian Institution

Washington, DC

(Surveys 1-4)

Edward C. Raney

Cornel. University

Ithaca, New York

(Surveys 6-7)

\section{Invertebrate Zoologists}

John M. Bates

University of Michigan

Ann Arbor, Michigan

(Surveys 6-7)

Leonard M. Bennetch

Academy of Natural Sciences

Philadelphia, Pennsylvania

(Surveys 1-4)

David Cook

National Museum of Canada

Ottawa, Ontario, Canada

(Surveys 13-16)

Samuel Fuller.

Department of Limnology Academy of. Natural Sciences Philadelphia, Pennsylvania (Surveys 12-13)
John J. Gallagher

3144 D Street

Philadelphia, Pennsylvania

(Surveys 5-7)

Horton H. Hobbs

U. S. National Museum

Washington, DC

(Surveys 5, 14-16)

Charles Hodge, IV

Temple University

Phildelphia, Pennsylvania

(Survey 5)

Roy Sawyer

College of Charleston

Charleston, South Carolina

(Surveys 14-16) 


\section{Phycologists}

Fay K. Dailey

Butler University

Indianapolis, Indiana

(Surveys 1-4)

William A. Daily

Butler University

Indianapolis, Indiana

(Surveys 1-9)

Francis Drouet

Department of Botany

Academy of Natural Sciences

Philadelphia, Pennsylvania

(Surveys 1-4, 8-16)

Charles M. Palmer

Environmental Health Center

Public Health Service

Cincinnati, Ohio

(Surveys 1-4)

Christine Parker

Division of Limnology

Academy of Natural Sciences

Philadelphia, Pennsylvania

(Survey 16)
Katherine E. Pearson

Department of Limnology

Academy of Natural Sciences

Philadelphia, Pennsylvania

(Surveys 8-9)

Noma Ann Roberts

Department of Limnology

Academy of Natural Sciences

Philadelphia, Pennsylvania

(Surveys 10-13)

Christine Smith

Department of Limnology

Academy of Natural Sciences

Philadelphia, Pennsylvania

(Surveys 14-15)

Lewis H. Tiffany

Department of Botany

Northwestern University

Evanston, Illinois

(Surveys 1-4)

Wilbur E. Wade

Michigan State University

East Lansing, Michigan

(Surveys 1-7)

Employees of E. I. du Pont de Nemours and Company, Inc. who have been directly involved in the Savannah River surveys include Raymond S. Harvey, John H. Horton, C. M. Patterson, Everett. W. Rabon, William C. Reinig, and Daniel I. Ross.

\section{CHAPTER III. SAVANNAB RIVER BASIN HISTORY*}

The Savannah. River drainage basin has a total area of 10,579 square miles $\left(27,388 \mathrm{~km}^{2}\right)$, and encompases all or part of 41 . counties. in Georgia, South Carolina and North Carolina (Figure 1). The Savannah River Basin is located in three physiographic regions: the Mountain Province, the Piedmont, and the Coastal Plain (Figure 2). The Mountain Province contains most of the major tributaries of the Savannah River, including the Seneca,

$\star$ Much of the information provided in this chapter was obtained from references 12-19. 


\section{NORTH CAROLINA}

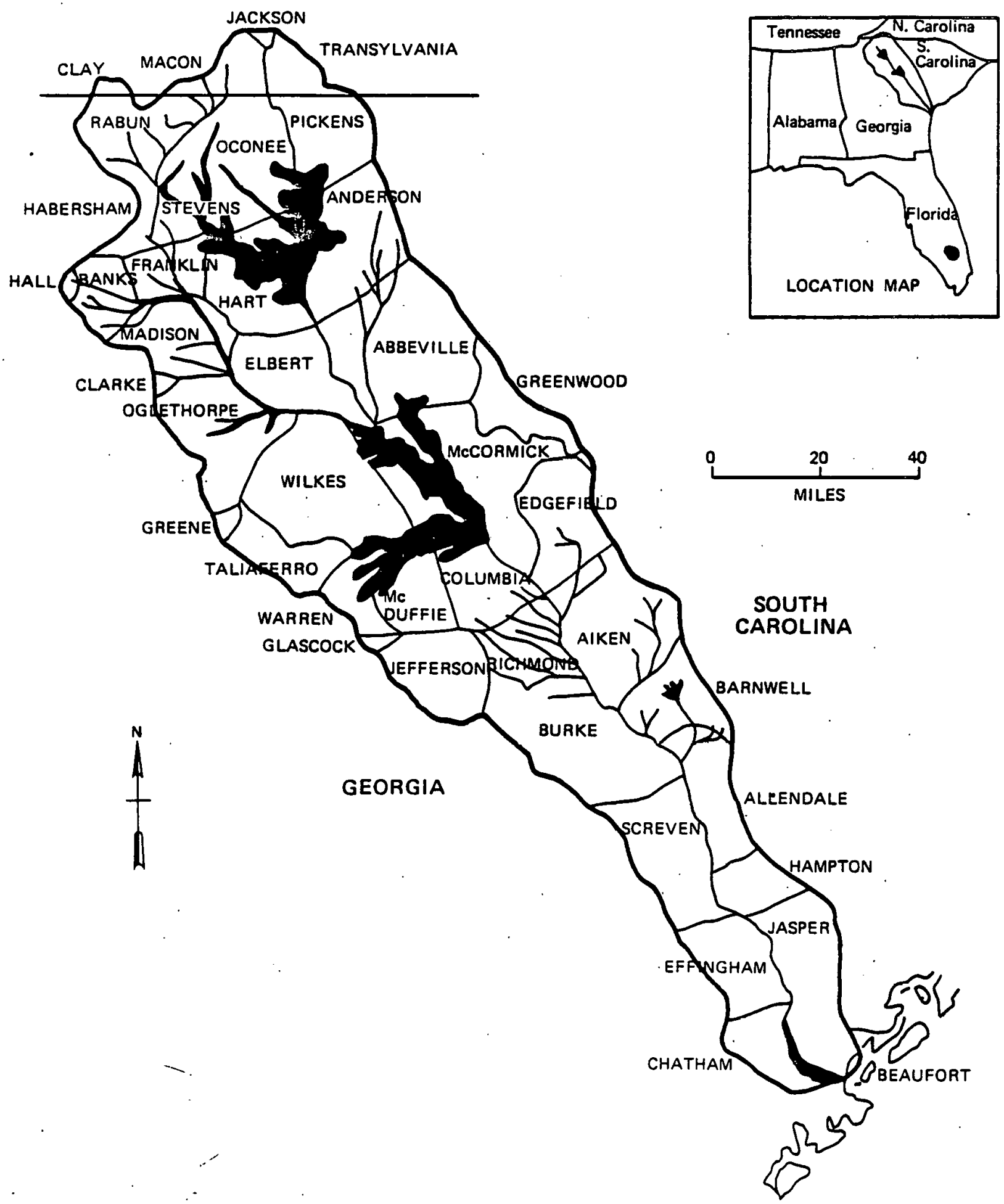

Figure 1. Counties Included Within the Savannah River Drainage Basin.

Reference 12. 


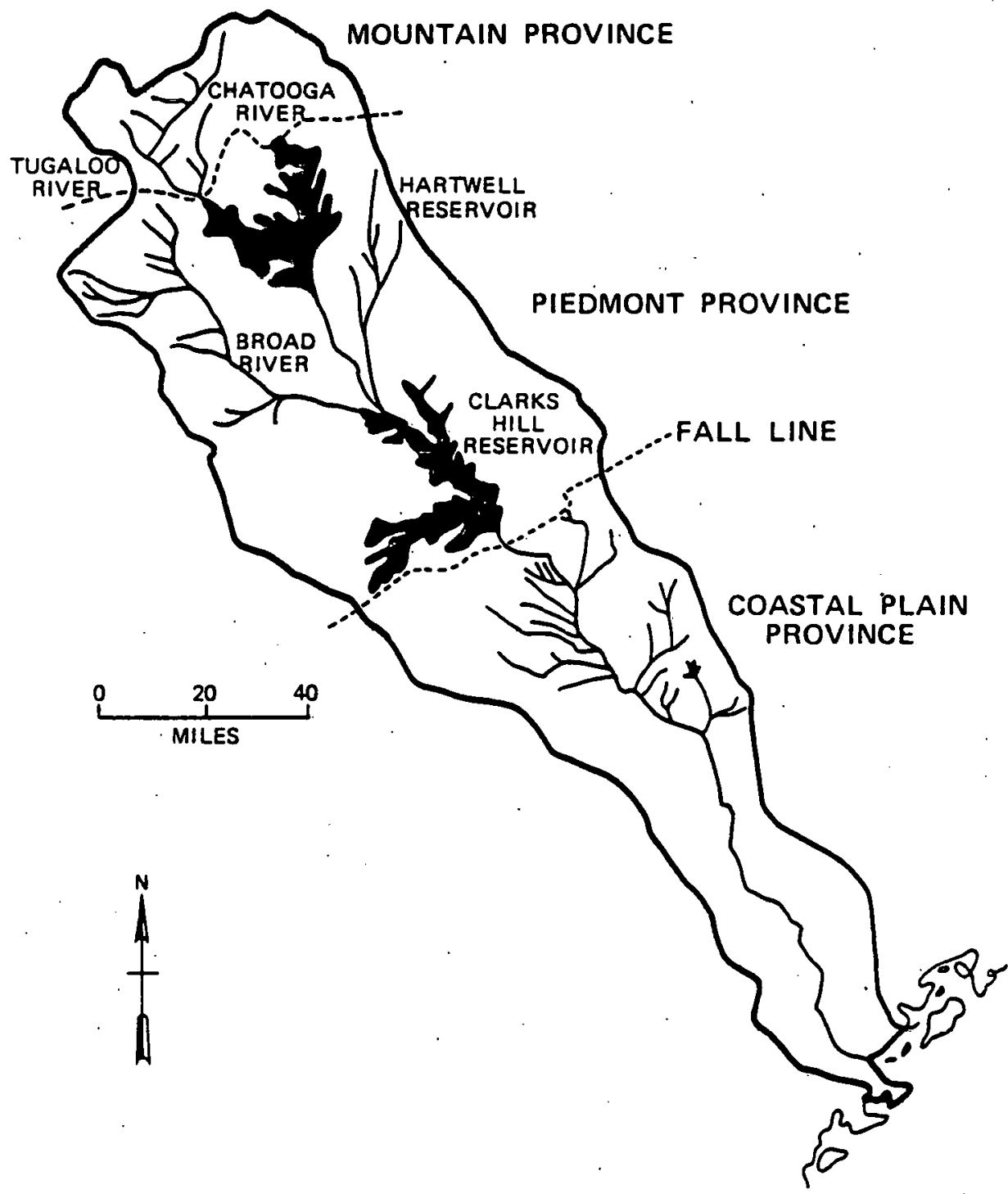

Figure 2. Major Tributaries and Physiographic Regions Included in the Savannah River Drainage Basin.

Reference 12. 
Tugaloo and Chattooga Rivers. The region is characterized by a relatively steep gradient, ranging from about 5,500 to $1,000 \mathrm{ft}$ $(1676$ to $305 \mathrm{~m})$, and includes $2,022 \mathrm{sq} \mathrm{mi}\left(5235 \mathrm{~km}^{2}\right)$ of the total drainage basin. The Mountain Province lies in the Blue Ridge, and has a bedrock composed of gneisses, granites, schists and quartzites; the subsoil is composed of brown and red sandy. clays. In this region the Savannah River and its tributaries have the character of mountain streams, with shallow riffles, clear creeks, and a fairly steep gradient. The stream bed is mainly sand and rubble, and the banks are sloping and grass-covered.

The Piedmont Region has an intermediate gradient, with elevations ranging from 1,000 to $200 \mathrm{ft}$ (305 to $61 \mathrm{~m})$. This region includes $5,233 \mathrm{sq} \mathrm{mi}\left(13,548 \mathrm{~km}^{2}\right)$ of the total drainage basin. Soils in the Piedmont are primarily red, sandy or silty clays, with weathered bedrock consisting of ancient sediments containing granitic intrusions. The Piedmont is bordered by the Fall-Line, an area where the sandy soils of the Coastal Plain meet the rocky terrain of the Piedmont foothills. The city of Augusta, Georgia, is located near this line.

The Savannah River becomes more turbid in the Piedmont Region, picking up the majority of its silt load. The river often meanders, and, despite the stabilizing effect of Clarks Hill Dam, the outer banks on curves are relatively unstable. Sand bars are deposited downstream from many inside banks along the curves.

The Coastal plain has a negligible gradient ranging from an elevation of $200 \mathrm{ft}(61 \mathrm{~m})$ to sea level. The soils of this region are primarily stratified silts, clays, and sands. The Coastal Plain contains $3,334 \mathrm{sq} \mathrm{mi}\left(8631 \mathrm{~km}^{2}\right)$ of the total Savannah River drainage area, and includes the city of Savannah, Georgia (Figure 2). In the Coastal Plain, the Savannah River is quite s.low moving. Tidal effects may be observed near the mouth of the river, and a salt water tongue extends upstream along the bottom of the river bed. The river bed is often muddy, and the river proper merges with the surrounding swamps.

Flow data for the Savannah River at Augusta (measured at But ler (reek) are given in Table 1. Typically, low flow occurs during the fall while high water occurs in late winter or early spring. The average discharge at Augusta calculated from 72 years of data, is $10,300 \mathrm{cfs}\left(292 \mathrm{~m}^{3} / \mathrm{sec}\right)$. More detailed flow and temperature data are given in Appendix $C$.

The water quality of the Savannah River and its tributaries varies considerably, ranging from clean to heavily contaminated with industrial and domestic effluents. The 1974 stream use 
TABLE 1

Minimum, Maximum, and Average Flows of the Savannah River (Measured at Augusta)*

\begin{tabular}{|c|c|c|c|}
\hline $\begin{array}{l}\text { Water Year } \\
\text { (Oct-Sept) }\end{array}$ & $\begin{array}{l}\text { Minimum } \\
\text { (cfs) }\end{array}$ & $\begin{array}{l}\text { Maximum } \\
\text { (cfs) }\end{array}$ & $\begin{array}{l}\text { Average } \\
\text { (cfs) }\end{array}$ \\
\hline $1950-51$ & 1,710 & 41,400 & 6,766 \\
\hline $\begin{array}{l}1951-52 \\
1952-53\end{array}$ & $\begin{array}{l}1,770 \\
3,260\end{array}$ & $\begin{array}{l}38,600 \\
34,800\end{array}$ & $\begin{array}{l}8,596 \\
6,561\end{array}$ \\
\hline $1953-54$ & 5,460 & 22,300 & 7,293 \\
\hline $1954-55$ & 4,180 & 22,400 & 5,487 \\
\hline $1955-56$ & 3,580 & 14,600 & 5,398 \\
\hline $1956-57$ & 5,170 & 15,200 & 6,572 \\
\hline $1957-58$ & 5,000 & 57,100 & 11,360 \\
\hline $1958-59$ & 5,260 & 28,200 & 7,125 \\
\hline $1959-60$ & 5,350 & 33,200 & $12 ; 450$ \\
\hline $1960-61$ & 4,930 & 30,300 & 8,873 \\
\hline $1961-62$ & 4,760 & 28,200 & 9,276 \\
\hline $1962-63$ & 5,130 & 30,600 & 9,554 \\
\hline $1963-64$ & 6,120 & 84,500 & 16,580 \\
\hline $1964-65$ & 6,300 & 33,000 & 12,940 \\
\hline $1965-66$ & 6,160 & 34,500 & 9,509 \\
\hline $1966-67$ & 5,740 & 20,900 & 8,372 \\
\hline $1967-68$ & 5,890 & 32,200 & 9,043 \\
\hline $1968-69$ & 5,800 & 44,100 & 9,812 \\
\hline $1969-70$ & 5,870 & 23,200 & 7,032 \\
\hline $1970-71$ & 4,460 & 59,700 & 8,668 \\
\hline $1971-72$ & 6,220 & 32,700 & 10,240 \\
\hline $1972-73$ & 5,460 & 38,100 & 13,200 \\
\hline $1973-74$ & 5,450 & 29,300 & 9,822 \\
\hline $1974-75$ & 5,520 & 43,900 & 11,690 \\
\hline $1975-76$ & 6,750 & 31,900 & 12,110 \\
\hline $1976-77$ & 6,000 & 32,200 & 11,030 \\
\hline
\end{tabular}

* Reference 19. 
classifications for the Savannah River Basin are given in Table 2. These classifications indicate the water quality at the time of the last Academy survey.

Historically, the Augusta, North Augusta, and Aiken County areas have provided the major sources of pollution to the Savannah River in the area around the Savannah River Plant. The city of Augusta did not have a secondary sewage treatment facility until 1975. Prior to that time most domestic and industrial wastes were discharged untreated or inadequately treated into the Savannah River, or into Hawks Gully, Butler Creek, and Spirit Creek, which flow into the Savannah River (Table 3). In the North Augusta and Aiken County area, domestic and industrial effluents entered the Savannah River directly and via Horse Creek and Lower Three Runs Creek (Table 4). Treatment facilities for the North Augusta and Aiken County area was not in operation until 1979. The Savannah River Plant also discharged waste water into the Savannah River. These discharges include thermal effluents as well as domestic and industrial wastes. The Savannah River Plant effluents are discussed in more detail in the next chapter.

Other pollution sources may be identified, particularly in the Savannah River Estuary near Savannah, Georgia. However, these sources did not have as great a potential for influencing the Academy of Natural Sciences of Philadelphia surveys as did those pollution sources from the Augusta area.

During the survey period there were a number of dams and impoundments built or in operation on the Savannah River. The largest of these were the Clarks Hill and the Hartwell Dams, located upstream from Augusta (Figure 2). The Clarks Hill Dam was completed in March, 1953 and is located $27 \mathrm{miles}(43 \mathrm{~km}$ ) above Augusta. Since the construction of Clarks Hill Dam, the Academy of Natural Sciences of Philadelphia survey teams have noted several changes in the Savannah River at their sampling station. River flow regulation increased the stability of the river banks by allowing vegetation, which previously had been torn loose from the banks by periodic floods, to build up along the river. In addition, there seemed to be an increase in water clarity as sediments settled out behind the dam. This increased clarity may have been partially responsible for the growth of dense algal mats in shallow river areas. The Academy hypothesized that because light was now able to penetrate farther into the water, the productivity of the river increased. The Academy also attributed part of the increased production to increasing industrial and domestic nutrient input into the river as cities and communities grew in the Savannah River Basin. Finally, the Academy noted a reduction in the number of snags and trash piles along the river. 
TABLE 2

Stream Use Classification of the Savannah River (1974)*

\begin{tabular}{|c|c|c|}
\hline Stream & Reach & Classification \\
\hline Chat tooga & $\begin{array}{l}\text { Georgia-North Carolina State Line to } \\
\text { Tugalo Reservoir }\end{array}$ & Wild \& Scenic \\
\hline $\begin{array}{l}\text { West Fork - } \\
\text { Chatooga River }\end{array}$ & $\begin{array}{l}\text { Confluence of Overflow Creek and Clear } \\
\text { Creek to Chatooga River }\end{array}$ & Wild \& Scenic \\
\hline Savannah River & $\begin{array}{l}\text { Headwaters of Tugalo Reservoir to } \\
\text { Clarks Hill Dam }\end{array}$ & Recreation \\
\hline Savannah River & $\begin{array}{l}\text { Clarks Hill Dam to Augusta, } \\
\text { 13th Street Bridge }\end{array}$ & Drinking Water \\
\hline $\begin{array}{l}\text { But ler Creek } \\
\text { (and its } \\
\text { tributaries) }\end{array}$ & $\begin{array}{l}\text { Headwaters in Augusta to confluence } \\
\text { with Savannah River }\end{array}$ & Urban \\
\hline $\begin{array}{l}\text { Cason's Dead River } \\
\text { (and its } \\
\text { tributaries) }\end{array}$ & $\begin{array}{l}\text { Headwaters in Augusta to confluence } \\
\text { with Savannah River }\end{array}$ & Urban \\
\hline Savannah River & $\begin{array}{l}\text { Augusta, } 13 \text { th Street Bridge to U. S. } \\
\text { Highway } 301 \text { Bridge }\end{array}$ & Fishing \\
\hline Savannah River & $\begin{array}{l}\text { U. S. Highway } 301 \text { Bridge to: U. S. } \\
\text { Highway } 17 \text { Bridge }\end{array}$ & Drinking Water \\
\hline Savannah River & $\begin{array}{l}\text { U. S. Highway } 17 \text { Bridge to Field's } \\
\text { Cut }\end{array}$ & $\begin{array}{l}\text { Industrial } \\
\text { Navigation }\end{array}$ \\
\hline Savannah River & Field's Cut to Fort Pulaski & Fishing \\
\hline Savannah River & $\begin{array}{l}\text { Fort Pulaski to open sea and all } \\
\text { littoral waters of Tybee Island }\end{array}$ & Recreation \\
\hline$\star \quad$ Reference 14. & & \\
\hline L* Water quality & $\begin{array}{l}\text { sifications are defined in the Geors } \\
\text { Rules of the Environmental Protect? }\end{array}$ & $\begin{array}{l}\text { Departme } \\
\text { Divis.ior }\end{array}$ \\
\hline
\end{tabular}


TABLE 3

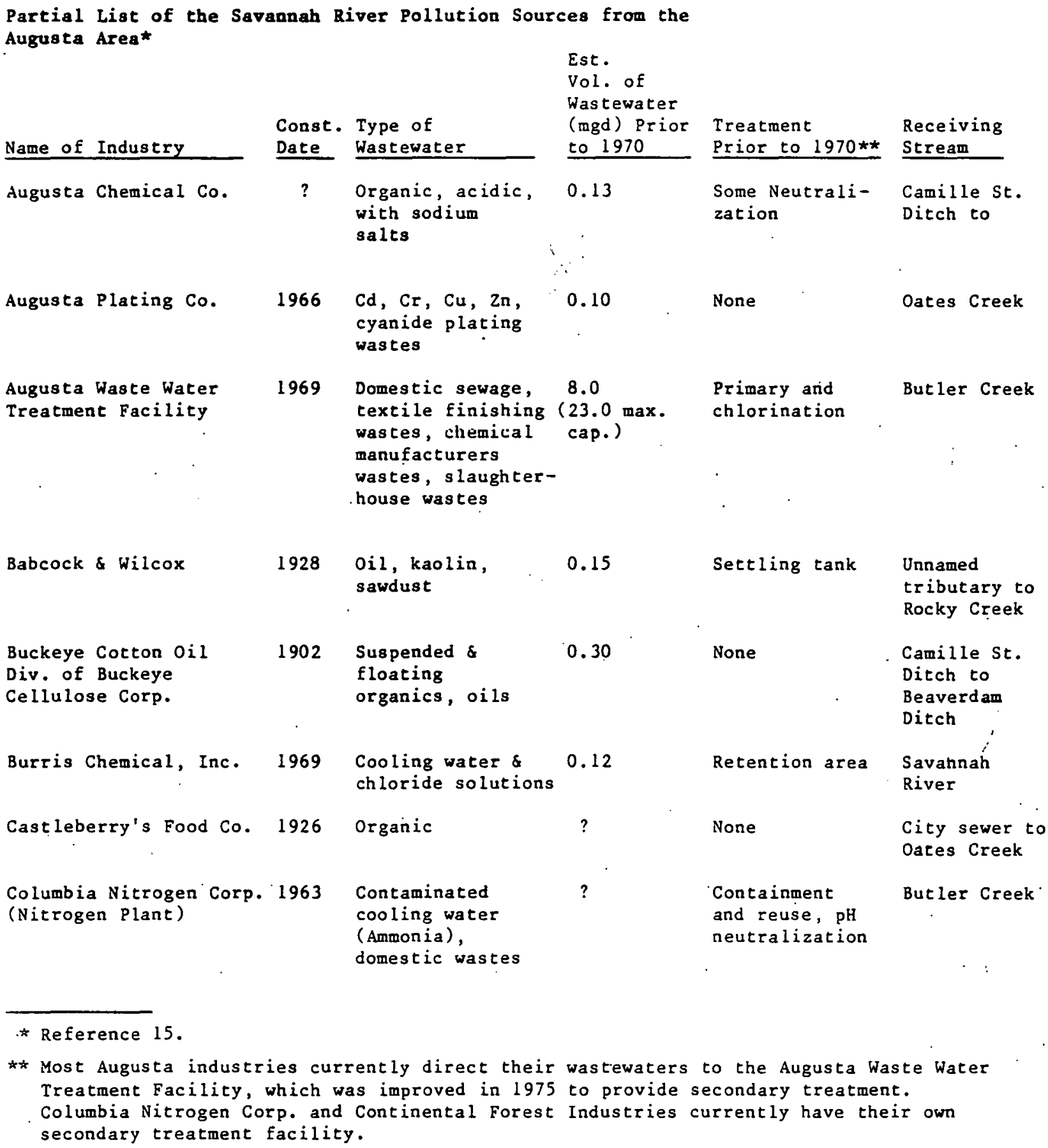


TABLB 3 (Contd)

\begin{tabular}{|c|c|c|c|c|c|}
\hline Name of Industry & $\begin{array}{l}\text { Const. } \\
\text { Date }\end{array}$ & $\begin{array}{l}\text { Type of } \\
\text { Wastewater }\end{array}$ & $\begin{array}{l}\text { Estimated } \\
\text { Vol. of } \\
\text { Wastewater } \\
\text { (mgd) } \\
\end{array}$ & $\begin{array}{l}\text { Treatment } \\
\text { Prior to } 1970\end{array}$ & $\begin{array}{l}\text { Receiving } \\
\text { Stream } \\
\end{array}$ \\
\hline $\begin{array}{l}\text { Columbia Nitrogen Corp. } \\
\text { (Caprolactam Plant) }\end{array}$ & 1963 & $\begin{array}{l}\text { Cooling water } \\
\text { domestic wastes } \\
\text { oil stripper } \\
\text { bottoms }\end{array}$ & 0.40 & $\begin{array}{l}\text { None } \\
\text { (Activated } \\
\text { sludge in } \\
\text { approx. i975) }\end{array}$ & $\begin{array}{l}\text { Savannah } \\
\text { River }\end{array}$ \\
\hline $\begin{array}{l}\text { Continental Forest } \\
\text { Industries. }\end{array}$ & 1960 & $\begin{array}{l}\text { Kraft Pulp } \\
\text { Mill Effluent }\end{array}$ & 0.50 & $\begin{array}{l}\text { Settling ponds, } \\
\text { aeration }\end{array}$ & Spirit Creek \\
\hline $\begin{array}{l}\text { E. I. du Pont Nemours } \\
\text { \& Co. }\end{array}$ & 1962 & $\begin{array}{l}\text { Inorganic } \\
\text { caustics }\end{array}$ & $?$ & Settling ponds & Butler Creek \\
\hline $\begin{array}{l}\text { Graniteville Mills, } \\
\text { Sibley Division }\end{array}$ & 1870 & $\begin{array}{l}\text { Dye, slasher; } \\
\text { and domestic }\end{array}$ & .28 & None & $\begin{array}{l}\text { Water wheel } \\
\text { tailrace ' to } \\
\text { Savannah } \\
\text { River }\end{array}$ \\
\hline $\begin{array}{l}\text { IMC (International } \\
\text { Minerals \& Chemicals }\end{array}$ & 1908 & $\begin{array}{l}\text { Cooling water } \\
\text { and scrubber } \\
\text { wastewater }\end{array}$ & .002 & None & Oates Creek \\
\hline J. P. King Mfg. Co. & 1881 & $\begin{array}{l}\text { Dye, slasher, } \\
\text { and domestic }\end{array}$ & .03 & None & $\begin{array}{l}\text { Water wheel } \\
\text { tailrace to } \\
\text { Savannah } \\
\text { River. }\end{array}$ \\
\hline Monsanto Company & 1962 & $\begin{array}{l}\text { Cooling water, } \\
\text { boiler blowdown, }\end{array}$ & .20 & Cooling ditch & $\begin{array}{l}\text { Ditch to } \\
\text { Butler Creek }\end{array}$ \\
\hline Olin Corp. & 1964. & $\mathrm{Hg}, \mathrm{chloride}$ & 2.5 & $\begin{array}{l}\mathrm{Hg} \text { recovery } \\
\text { and } \mathrm{pH} \\
\text { neutralization }\end{array}$ & $\begin{array}{l}\text { Savaniah } \\
\text { River }\end{array}$ \\
\hline Philadelphia Quartz Co. & $?$ & $\begin{array}{l}\text { Inorganic. } \\
\text { caustics }\end{array}$ & .008 & $\begin{array}{l}\text { Two holding } \\
\text { ponds. }\end{array}$ & $\begin{array}{l}\text { Savannah } \\
\text { River. }\end{array}$ \\
\hline Riverside Mills & $?$ & $\begin{array}{l}\text { Organic } \\
\text { acidic }\end{array}$ & .30 & None & $\begin{array}{l}\text { City sewer } \\
\text { to Third } \\
\text { Level Canal }\end{array}$ \\
\hline $\begin{array}{l}\text { Scott Meat Packers, } \\
\text { Inc. }\end{array}$ & 1939 & Blood, washwater & .12 & None & Riocky Creek \\
\hline
\end{tabular}


TABLE 3 (Contd)

\begin{tabular}{|c|c|c|c|c|c|}
\hline Name of Industry & $\begin{array}{l}\text { Const. } \\
\text { Date }\end{array}$ & $\begin{array}{l}\text { Type of } \\
\text { Wastewater }\end{array}$ & $\begin{array}{l}\text { Estimated } \\
\text { Vol. of } \\
\text { Wastewater } \\
\text { (mgd) } \\
\end{array}$ & $\begin{array}{l}\text { Treatment } \\
\text { Prior to } 1970 \\
\end{array}$ & $\begin{array}{l}\text { Receiving } \\
\text { Stream }\end{array}$ \\
\hline $\begin{array}{l}\text { Shapiro Packing Co., } \\
\text { Inc. }\end{array}$ & 1940 & Organic & ? & Grease trap & $\begin{array}{l}\text { Most of waste } \\
\text { to sanitary } \\
\text { sewers, small } \\
\text { amount to } \\
\text { Camille Street } \\
\text { Ditch }\end{array}$ \\
\hline Swift Fresh Meats Co. & 1897 & Organic & $?$ & Floor.grates & $\begin{array}{l}\text { Second Level } \\
\text { Canal }\end{array}$ \\
\hline Taylor-Piedmont Co. & $?$ & Creosote, oils & .90 & None & Rocky Creek \\
\hline
\end{tabular}


TABLB 4

Partial List of the Savannah River Pollution Sources from the North Augusta and Aiken County Areas*

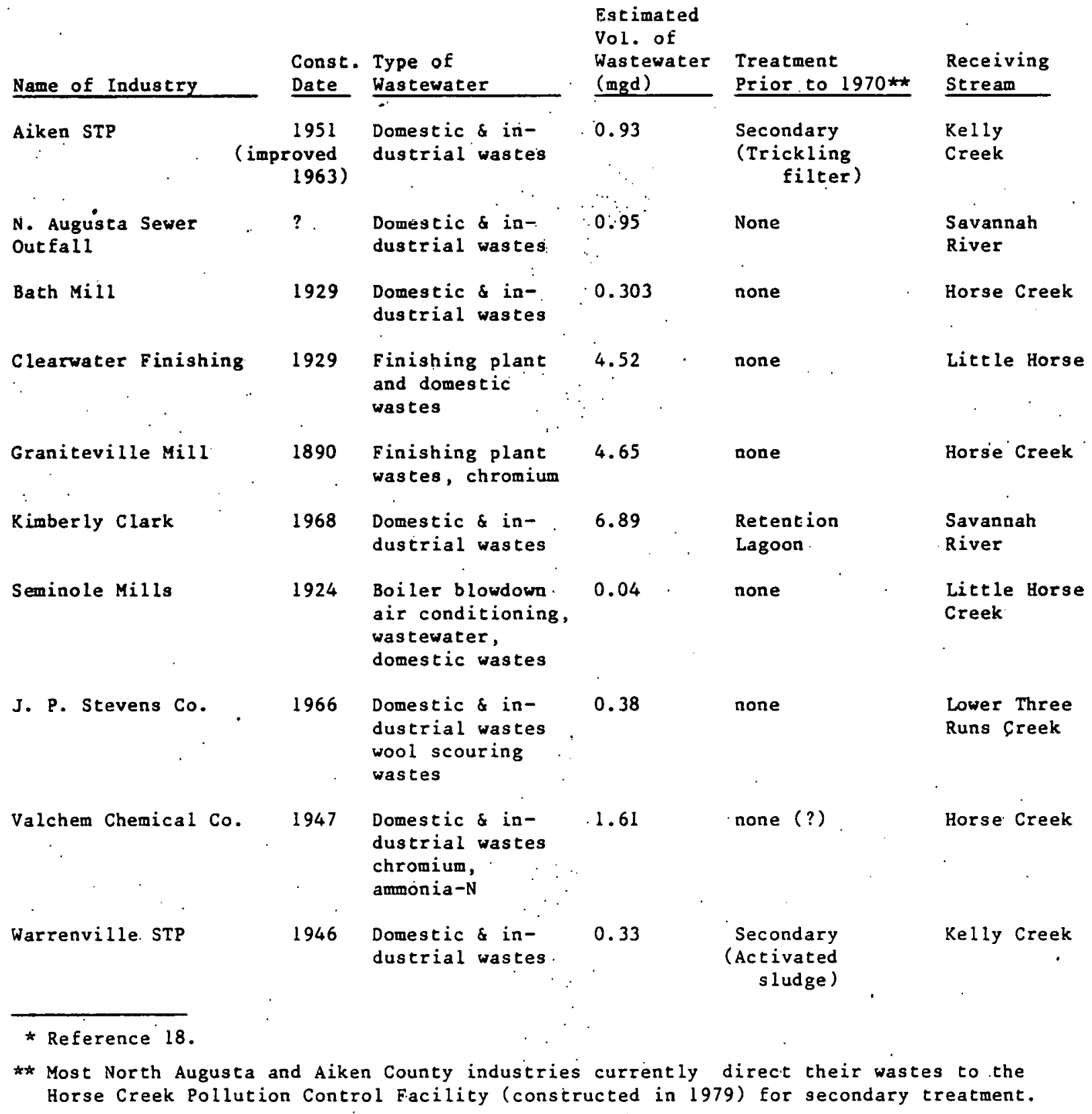


The second major dam is Hartwell Dam, which was completed in June, 1962. Hartwell Dam is located in the headwater region of the Savannah River about 65 miles ( $105 \mathrm{~km}$ ) upstream from the Clarks Hill Dam. A third large dam, the Richard B. Russell Dam, is being built between the Clarks Hill and Hartwell Dams, but it will not be completed until 1984 or 1985. Several other small dams are located along the river, including three near Augusta: New Savannah Bluff Lock and Dam (completed in 1937), Stevens Creek Dam (completed in 1914), and Augusta City Dam (rebuilt in 1863).

A program that may have had considerable short-term implications on the surveys, was the dredging operations conducted by the U. S. Corps of Engineers. This program, initiated in October, 1958 , was designed to dredge and maintain a $9 \mathrm{ft}$ navigation channel in the Savannah River from the city of Savannah to Augusta.* A total of 61 sets of pile dikes were placed to constrict the river flow, thereby increasing flow rates, and a total of 37,645 linear ft of wood and stone revetment was laid to reduce erosion on banks opposite from the dikes. In addition, the channel was dredged, and 31 cutoffs were made, reducing the total river distance from Augusta to Savannah by about 15 miles $(24.1 \mathrm{~km})$. The project was completed in July, 1965; however, periodic dredging was continued to maintain the channel. A table of dredging dates and locations is included in Table 5 .

The Savannah River Plant, which began construction in 1951, was another source of potential impact on the Savannah River. The major purpose of the Academy's surveys in the Savannah River was to monitor the effects of the Savannah River Plant. The next chapter will discuss the Savannah River Plant activities from a historical aspect to evaluate some of the possible sources of impact by the Savannah River Plant on the Savannah River.

\section{CHAPTER IV. SAVANNAH RIVER PLANT ACTIVITIES}

The Savannah River Plant (Figures 3-4) consists of a total of five nuclear production reactors and supporting facilities. 20,21 Three of the reactors are currently operational ( $P, K$, and $C$ ), and two are on stand-by ( $R$ and $L$ ). In addition, a small test reactor (U) is on stand-by. Nuclear fuel and targets are manufactured on the site in the fuel and target fabrication facility (M). The irradiated reactor products are processed and packaged for shipment in the chemical separations areas ( $F$ and $H$ ). Deuterium,

\footnotetext{
* Some dikes and revetments had been laid earlier, and were in place at the start of the Savannah River surveys in 1951 .
} 
TABLE 5

Savannah River Dredging Activities, 1964 through 1974 (Partial Listing)*

Dates

1964

Dec. 7-10

Dec. $10-12$

Dec. 13

Dec. 14-17

Dec. 18-22

Dec. 23-30

Dec, 31

1965 Jan. 2-5

Jan. 5

Jan. 6

1966 April 22-25

April 26 - May 2

May 3-4.

May 4-9

May 9-10.

May $11-12$

May 12-13

1967 June 3-5

June 6-16

June 17-22

June 22 - July 9

July 10 - Aug. 4

Aug. 4 - Aug. 10

Aug. 10

Aug. 11

1968 Sept. 8

Sept. 9

Sept. 24-25

Sept. 26

Sept, 27

Sept. 26 - Oct. 4

Det. 5-6

Oct. 6-7

\section{River Miles Dredged}

$176.0-175.4$

$175.2-174.8$

165.5

$158.4-159.0$

$158.1-157.2$

$141.3-140.8$

$137.3-136.8$

$135.6-135.3$

129.2

118.7 (Rt 301 Bridge)

$173.8 * *$

$162.0 * *$

$151.0 * *$

$149.0 * t$

$144.0 * *$

$126.0 * *$

$124.5 * *$

$197.9-179.8$

$179.8-175.0$.

$175.0-174.3$

$174.3-169.0$

$169.0-135.0$

$135.0-134.4$

128.4

59.4

above 167.1

167.1

$151.3-151.1$

$144.2-144.1$

$1.36 .5-136.3$

$129.3-128.9$

$124.6-124.0$

$114.5-114.2$

* Reference 16 .

$\because$ only average river mile values were available. 
TABLE 5 (Contd)

Dates

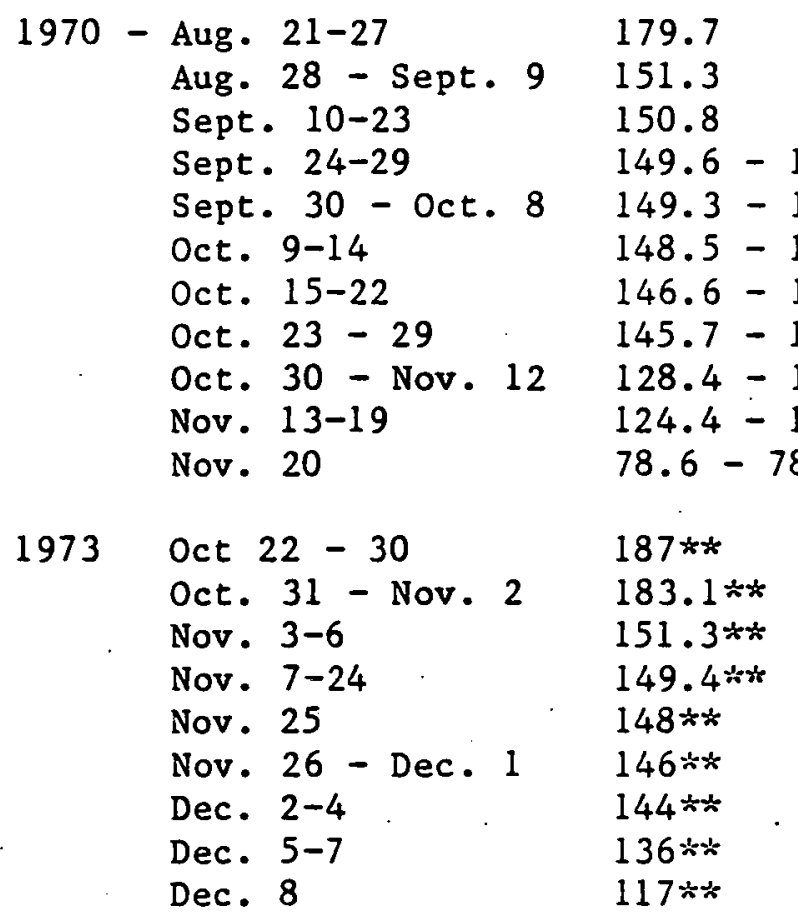

** Only average river mile values were available. 


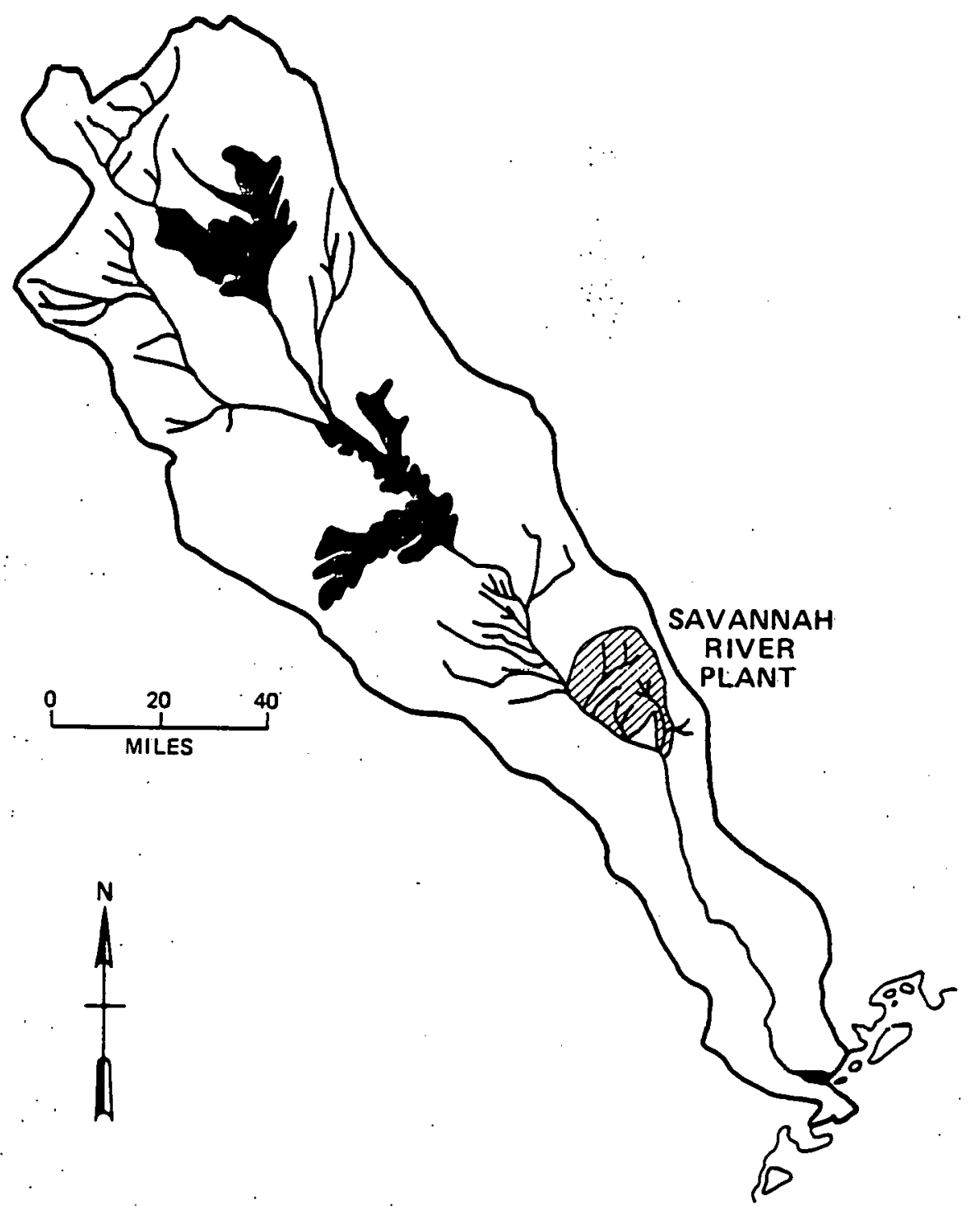

Figure 3. Location of the Savannah River Plant in the Savannah River Drainage Basin. 


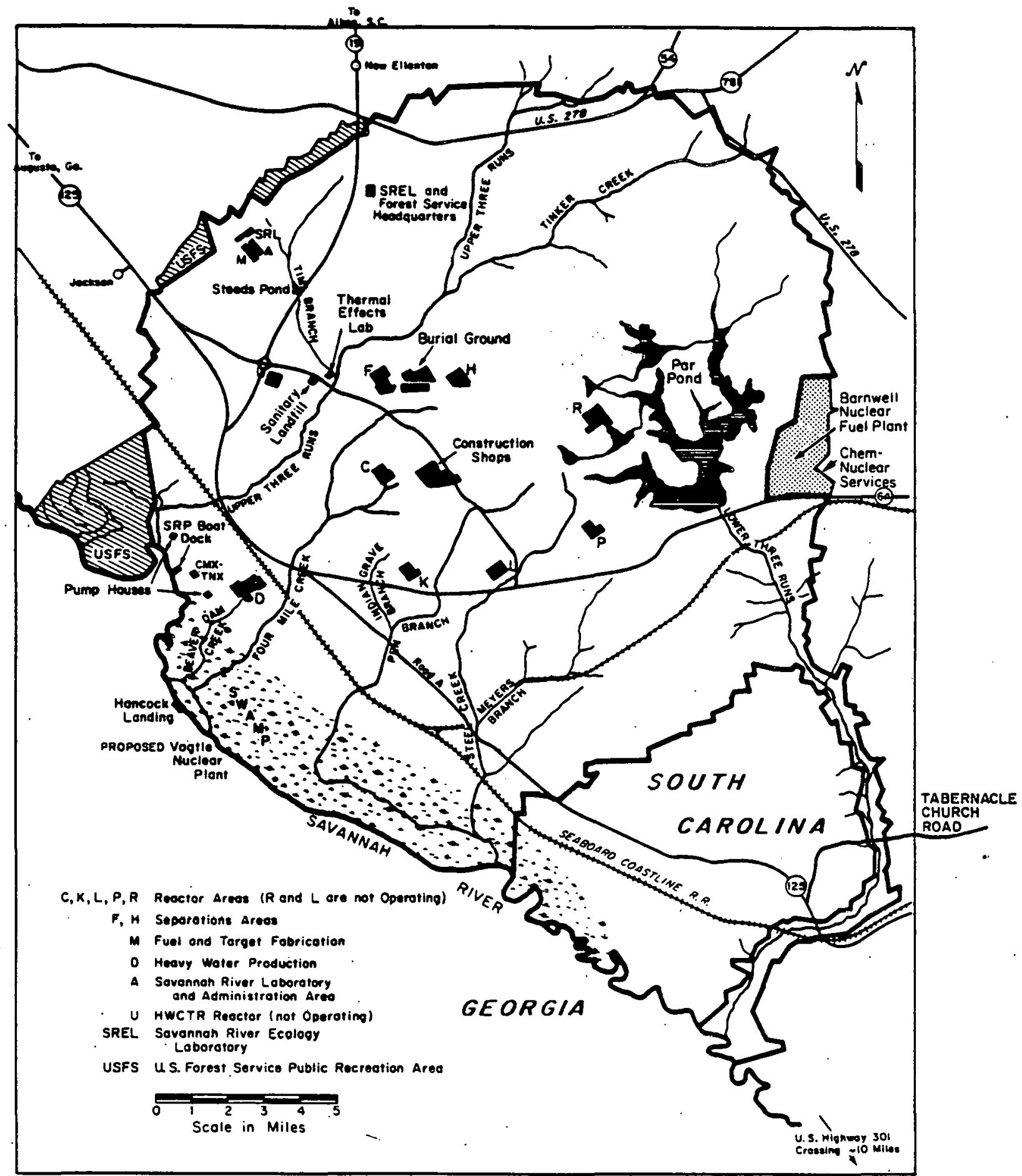

Figure 4. The Savannah River Plant Site. 
which is used to moderate the neutron activity inside the reactor, is separated from Savannah River water in the heavy water extraction and recovery area (D). Other facilities include the Savannah River Laboratory, a process development laboratory, and administrative areas (A).

The major products produced at the Savannah River Plant are ${ }^{239} \mathrm{Pu}$ and ${ }^{\mathrm{H}}$. Smaller quantities of other nuclear materials have been produced. Some of these products include:

1) $238 \mathrm{Pu}$, a self-contained energy source used as a power supply in pacemakers and for the space program

2) $252 \mathrm{Cf}$, an active neutron source useful in radiography, activation analysis, and possible cancer therapy

3) ${ }^{60} \mathrm{Co}$, a gamma ray source used in cancer therapy and selfcontained power sources

4) $244 \mathrm{Cm}$, a potential power source

5) $233_{\mathrm{U}}$, a research material loaned to Universities and other research facilities.

The Savannah River Plant operations produce nuclear wastes, as well as a variety of industrial and domestic wastes. Most nuclear wastes are processed and stored on the site. Industrial and domes$t i c$ wastes, and some radionuclides are processed if necessary, and released to drainage ditches and seepage basins. As part of a comprehensive program to monitor the effects of these wastes on the environment, the Academy of Natural Sciences of Philadelphia was contracted to evaluate the impact of the Savannah River Plant on the health of the Savannah River.

Effluents released to the Savannah River, or to seepage basins that drain into tributaries of the Savannah River, contain exceedingly low levels of radionuclides and of her materials. Tables 6 through 9 list the major compounds found in Savannah River Plant effluents, 20 and show the effect of these compounds on chemical concentrations and bacterial numbers in the Savannah River.

One of the most important potential impacts that the Savannah River Plant has is from thermal effluents. Large quantities of river water are pumped through heat exchangers in the reactor buildings, then are returned to the river by way of Four Mile Creek, Beaver Dam Creek, and Pen Branch Creek (Figure 4). Steel Creek and Lower Three Runs Creek have also been used during the 1951-1976 survey period to transport thermal effluents. A summary of the history of reactor operations is shown in Table 10 . 


\section{TABLE 6}

Radioactivity in Savannah River Water (1975)*

\begin{tabular}{|c|c|c|c|c|c|c|}
\hline \multirow[b]{2}{*}{ Sampling Point } & \multirow{2}{*}{$\begin{array}{l}\text { Alpha } \\
\left(10^{-9}\right. \\
\underline{\text { Max }}\end{array}$} & \multicolumn{2}{|c|}{$\begin{array}{l}\text { Emitters } \\
\mu \mathrm{Ci} / \mathrm{cc}) \\
\end{array}$} & \multicolumn{3}{|c|}{$\begin{array}{l}\text { Nonvolatile } \\
\text { Beta Emitters }{ }^{+2 *} \\
\left(10^{-9} \mu \mathrm{Ci} / \mathrm{cc}\right)\end{array}$} \\
\hline & & $\underline{\text { Min }}$ & Ave & $\underline{\text { Max }}$ & Min & Avg \\
\hline $\begin{array}{l}\text { Above SRP, } 1 \text { mile } \\
\text { upstream from Upper } \\
\text { Three Runs }\end{array}$ & $1: 0$ & $\mathrm{ND} \dagger$ & ND & 6 & ND & ND \\
\hline $\begin{array}{l}\text { Below SRP, } 8 \text { miles } \\
\text { downstream from } \\
\text { Lower Three Runs at } \\
\text { Highway } 301\end{array}$ & 1.5 & ND & ND & 7 & ND & ND \\
\hline
\end{tabular}

* Reference 20.

** Tritium and small amounts of $137 \mathrm{Cs}$ and $90 \mathrm{Sr}$ are the only radionuclides of SRP origin detectable by routine monitoring in river water at the downstream location.

$\dagger \quad N D=$ not detectable (less than sensitivity of analysis). Alpha emitter minimum sensitivity $=0: 2 \times 10^{-9} \mu \mathrm{Ci} / \mathrm{cc}$ Nonvolatile beta emitter minimum sensitivity $=4.0 \times 10^{-9} \mu \mathrm{Ci} / \mathrm{cc}$. 


\section{TABLE 7}

Comparison of Changes in Savannah River Water Quality with Drinking Water Standards $(1975)^{a}$

\begin{tabular}{|c|c|c|c|c|}
\hline Material & $\begin{array}{l}\text { Changes in Sava } \\
\text { Concentrations } \\
\text { From SRP Releas } \\
\end{array}$ & $\begin{array}{l}\text { annah River } \\
\text { Resulting } \\
\text { se (mg/L) }\end{array}$ & $\begin{array}{l}\text { Drinking } \\
\text { Standard, } \\
\end{array}$ & $\begin{array}{l}\text { Water } \\
(\mathrm{mg} / \mathrm{L})\end{array}$ \\
\hline Sulfate & 0.2 & & 250 & \\
\hline Chloride & 0.05 & & 250 & \\
\hline Nitrate & 0.01 & & .10 & \\
\hline Phosphate & $3 \times 10^{-3}$ & & $d$ & . \\
\hline Barium & $1.7 \times 10^{-3}$ & & 1.0 & \\
\hline Iron & $4.9 \times 10^{-4}$ & . & 0.3 & \\
\hline Boron & $1.8 \times 10^{-4}$ & & 1.0 & \\
\hline Zinc & $1.5 \times 10^{-4}$ & & 5 & \\
\hline Chromium & $4 \times 10^{-5}$ & . & 0.05 & \\
\hline Manganese & $9 \times 10^{-5}$ & & 0.05 & \\
\hline Arsenic & I. $\times 10^{-5}$ & & 0.05 & \\
\hline Mercury & $9 \times 10^{-8}$ & · & 0.002 & \\
\hline Copper & $1.3 \times 10^{-6}$ & . & 1 & \\
\hline Phenols & $1.7 \times 10^{-7}$ & & 0.001 & \\
\hline Cyanide & c & & 0.2 & \\
\hline Cadinium & $c$ & & 0.01 & \\
\hline Lead & $c^{\prime}$ & & 0.05 & \\
\hline Selenium & $c$ & & 0.01 & \\
\hline Silver & $c$ & & 0.05 & \\
\hline
\end{tabular}

a. References 20,22 .

b. Assumes minimum flow of 6000 cfs. Concentrations downstream of SRP are all below the standards.

c. Not normally discharged to streams at SRP.

d. No drinking water standard in 1975 . 
Pesticides Analyzed by OSGS $^{\mathrm{a}}$ in Savannah River Sediment and Water Samples (1975).

River Sediment, $\mu g / \mathrm{kg}$

Above plant Below Plant

\begin{tabular}{|c|c|c|}
\hline Aldrin ${ }^{b}$ & d & $d$ \\
\hline Chlordane & d & $d$ \\
\hline $\mathrm{DDD}^{\mathrm{b}}$ & 1.0 & 3.2 \\
\hline$D D E^{b}$ & 1.2 & 3.4 \\
\hline $\mathrm{DDT}^{\mathrm{b}}$ & 1.3 & 4.1 \\
\hline Diazinon ${ }^{b}$ & $d$ & d \\
\hline Dieldrin & 0.5 & 1.4 \\
\hline Endrin ${ }^{b}$ & d & $d$ \\
\hline Ethion ${ }^{b}$ & $\mathrm{~d}$ & $\mathrm{~d}$ \\
\hline E thy l-Parathion ${ }^{b}$ & d & $\mathrm{d}$ \\
\hline Ethyl-Trithion ${ }^{b}$ & d & $d$ \\
\hline Heptach lor ${ }^{b}$ & d & d \\
\hline Heptach lor-Epox ${ }^{b}$ & d & d \\
\hline Lind ane $^{b}$ & d & $\mathrm{d}$ \\
\hline Malathion ${ }^{b}$ & $d$ & $\mathrm{~d}$ \\
\hline Methoxychlor ${ }^{c}$ & d & $d$ \\
\hline Methyl-Parathion ${ }^{b}$ & d & d \\
\hline Methy 1-Trithionb: & d & d \\
\hline $\mathrm{PCB}^{\mathrm{b}}$ & d & 9.0 \\
\hline $\mathrm{PCN}^{\mathrm{b}}$ & d & $\mathrm{d}$ \\
\hline Silvex ${ }^{b}$ & d & $d$ \\
\hline Toxaphene & d & d \\
\hline $2,4-D^{b}$ & d & $d$ \\
\hline $2,4-D P^{b}$ & $d$ & $d$ \\
\hline $2,4,5-T^{b}$ & d & $d$ \\
\hline
\end{tabular}

a. Limit of sensitivity of each analysis is $0.1 \mu \mathrm{g} / \mathrm{L}$ of water and $1.0 \mu \mathrm{g} / \mathrm{kg}$ of sediment. Reference 20 .

b. Water and sediment analyses.

c. Water arialyses only.

d. Below limit of sensitivity. 
TABLE 9

Fecal Coliform Bacteria Measurements (1975)*

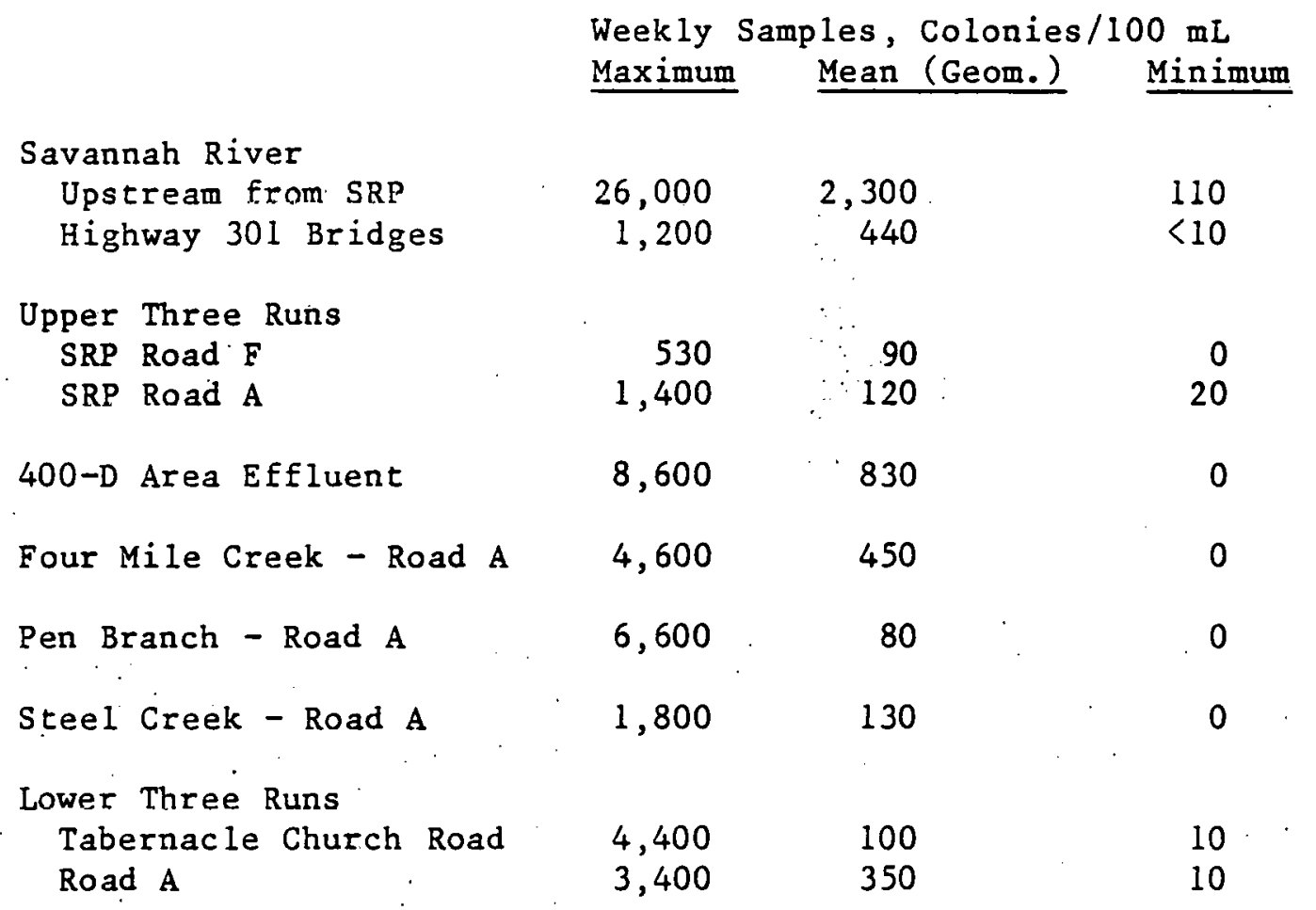

* Reference 20. Data from the Academy of Natural Sciences of Philadelphia are included in Table B.4.23 (Appendix B) for comparison. 
TABLE 10

Startup and Stand-by Dates of the Savannah River Plant Reactors

Reactor Startup Stand-by

$R * \quad 12 / 28 / 53 \quad 6 / 15 / 64$

$P * * \quad 2 / 20 / 54$

Lt $\quad 7 / 02 / 54 \quad 2 / 18 / 68$

$\mathrm{RT+} \quad 10 / 14 / 54$

Cצ

$3 / 28 / 55$

* Discharge to Lower Three Runs until 1958, then discharge to Par Pond.

** Discharge to Steel Creek until 1963, then discharge to Par Pond.

$\dagger$ Discharge to Steel Creek.

tt Discharge to Pen Branch Creek.

I Discharge to Four Mile Creek. 
Typically, the thermal effluents from the Savannah River Plant area create plumes in the river which mix slowly with the rest of the river. Thermal profiles for the Savannah River below Four Mile Creek and Steel Creek (Pen Branch effluent) are shown in Tables 11 and 12. The maximum river temperature recorded below the Savannah River Plant after mixing was $29.4^{\circ} \mathrm{C}$ on August 25, 1959 (Table 13).

The Academy of Natural Sciences of Philadelphia has conducted 16 major surveys on the Savannah River to monitor the effluence of the Savannah River Plant. These surveys, and the Academy's monitoring program, are described in more detail in the next chapters.

\section{CHAPTER $\nabla$. CHRONOLOGY OF SURVEYS AND STUDIES}

There have been a total of 16 major surveys conducted by the Academy of Natural Sciences of Philadelphia on the Savannah River from 1951 to $1976^{-}$(Table 14). These surveys have produced a comprehensive, taxonomic data base covering the entire span of the Savannah River Plant's operations. The biological and chemical data from these surveys have been used to evaluate the impact of thermal effluents from the Savannah River Plant reactors, particularly L reactor, on the Savannah River. 10 Other comparisons between biological data and reactor activity may be made using one or more of the data formats discussed in Chapter VIII (Scope of the Savannah River Plant Data Base).

In addition to the comprehensive river surveys, diatometer data have been collected quarterly from 1953 to 1976 at stations 1 , 6 , and $A B$. These data represent a semi-continuous biomonitoring program that may be used to supplement the major survey data. Chapter IX and Appendices A and B provide a summary of the biological and chemical data available for each survey.

The Savannah River has been influenced by many changes that have occurred during the 25 year sampling period. The most notable impacts resulted from dredging of the river, industrialization along the river banks, and construction of upstream dams. The impacts resulting from these operations are detailed in Chapters III, IV, and VI.

\section{CHAPTER VI. SAMPLING STATIONS}

A number of criteria were used to select the location of sampling stations on the Savannah River.1-9 The Academy survey team wanted stations with comparable ecological habitats. The total area to be sampled was of less importance than the inclusion of a similar variety of habitats. In addition, the stations should have similar physlcal and chemical charateristics 
TABLE 11

River Temperatures Near Four Mile Creek (Measured 4/10/72)*

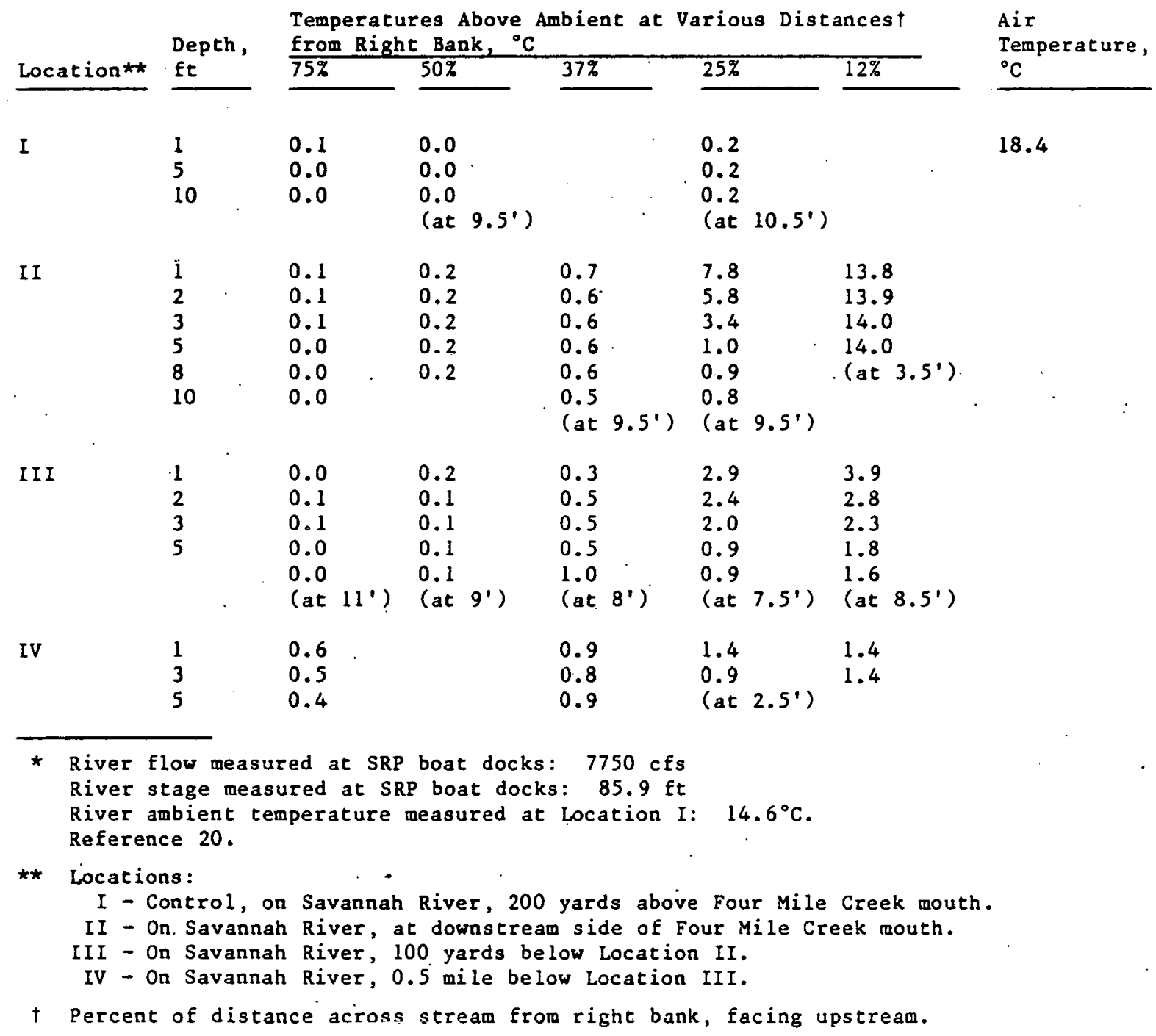


TABLE 12

River Temperatures Near Steel Creek (Measured 4/13/72)*

\begin{tabular}{|c|c|c|c|c|c|c|c|c|c|}
\hline Location $* \star$ & $\begin{array}{l}\text { Depth, } \\
\text { ft }\end{array}$ & $\begin{array}{l}\text { Temperatur } \\
\text { from Right } \\
75 \%\end{array}$ & $\begin{array}{l}\text { es Above Amb } \\
\text { Bank, }{ }^{\circ} \mathrm{C} \\
50 \%\end{array}$ & $\begin{array}{l}\text { ient at Var } \\
37 \%\end{array}$ & Lous & 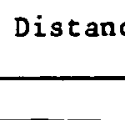 & $12 \%$ & & $\begin{array}{l}\text { Temperature, } \\
{ }^{\circ} \mathrm{C}\end{array}$ \\
\hline I & $\begin{array}{l}1 \\
5 \\
10\end{array}$ & $\begin{array}{l}0.0 \\
0.0 \\
0.0 \\
0.0 \\
\text { (at } 11.5^{\prime} \text { ) }\end{array}$ & $\begin{array}{l}0.0 \\
0.0 \\
0.0\end{array}$ & & $\begin{array}{l}0.0 \\
0.0 \\
0.0 \\
0.0 \\
\text { at }\end{array}$ & $\left.11^{\prime}\right)$ & & 28.6 & 27.8 \\
\hline . & $\begin{array}{l}1 \\
2 \\
3 \\
5 \\
10\end{array}$ & $\begin{array}{l}0.2 \\
0.2 \\
0.1 \\
0.1 \\
0.1 \\
\text { (at } 7^{\prime} \text { ) }\end{array}$ & $\begin{array}{l}0.0 \\
0.0 \\
0.0 \\
0.0 \\
0.0 \\
\left(\text { at } 10.5^{\prime}\right)\end{array}$ & $\begin{array}{l}0.0 \\
0.0 \\
0.0 \\
0.0 \\
0.0 \\
0.0 \\
\text { (at } 14^{\prime} \text { ) }\end{array}$ & $\begin{array}{l}0.0 \\
1.2 \\
1.1 \\
1.1 \\
0.3 \\
0.1 \\
\text { (at }\end{array}$ & $\left(5.5^{\prime}\right)$ & $\begin{array}{l}2.4 \\
3.0 \\
3.0 \\
1.4 \\
1.1 \\
0.4 \\
\text { (at }\end{array}$ & $\left.14^{\prime}\right)$ & \\
\hline III & $\begin{array}{l}1 \\
2 \\
3 \\
5 \\
10\end{array}$ & $\begin{array}{l}0.1 \\
0.1 \\
0.1 \\
0.0 \\
0.0\end{array}$ & $\begin{array}{l}0.0 \\
0.0 \\
0.0 \\
0.0 \\
0.0 \\
\text { (at } 9.5^{\prime} \text { ) }\end{array}$ & $\begin{array}{l}0.0 \\
0.0 \\
0.0 \\
0.0 \\
0.0 \\
0.0 \\
\left(\text { at } 11.5^{\prime}\right)\end{array}$ & $\begin{array}{l}0.1 \\
0.0 \\
1.1 \\
0.1 \\
0.1 \\
0.1 \\
\text { (at }\end{array}$ & (3') & $\begin{array}{l}0.9 \\
1.2 \\
1.2 \\
1.1 \\
0.8 \\
0.8 \\
\text { (at }\end{array}$ & $\left.14.5^{\prime}\right)$ & 30.0 \\
\hline IV & $\begin{array}{l}1 \\
5\end{array}$ & $\begin{array}{l}0.4 \\
0.2 \\
0.2 \\
\left(\text { at } 7^{\prime}\right)\end{array}$ & $\begin{array}{l}0.1 \\
0.1 \\
0.1 \\
\left(\text { at } 8^{\prime}\right)\end{array}$ & $\begin{array}{l}0.2 \\
0.2 \\
0.2 \\
\left(\text { at } 8.5^{\prime}\right)\end{array}$ & $\begin{array}{l}.0 .5 \\
0.5 \\
0.5 \\
\text { (at }\end{array}$ & $\left(0.5^{\prime}\right)$ & $\begin{array}{l}0.9 \\
0.8 \\
0.9 \\
\text { (at }\end{array}$ & $\left.12.6^{\prime}\right)$ & \\
\hline $\mathbf{v}$ & $\begin{array}{l}1 \\
5 \\
10\end{array}$ & $\begin{array}{l}0.5 \\
0.4 \\
0.3 \\
0.3 \\
\text { (at 23') }\end{array}$ & $\begin{array}{l}0.6 \\
0.6 \\
0.5 \\
0.3 \\
\text { (at 20') }\end{array}$ & & $\begin{array}{l}0.7 \\
0.7 \\
0.7 \\
0.7 \\
\text { (at }\end{array}$ & $\left.13^{\prime}\right)$ & & & 8.9 \\
\hline VI & $\begin{array}{l}1 \\
5 \\
10\end{array}$ & $\begin{array}{l}0.6 \\
0.5 \\
0.5 \\
0.5 \\
\text { (at 11') }\end{array}$ & $\begin{array}{l}0.5 \\
0.4 \\
0.4 \\
0.4 \\
\text { (at } 14^{\prime} \text { ) }\end{array}$ & & $\begin{array}{l}0.5 \\
0.5 \\
0.5 \\
0.5 \\
\text { (at }\end{array}$ & $\left.15.5^{\prime}\right)$ & & . & 29.0 \\
\hline
\end{tabular}

* River flow measured at SRP boat docks: 7450 cfs

River stage measured at SRP boat docks: $85.5 \mathrm{ft}$

River ambient temperature measured at Location I: $16.9^{\circ} \mathrm{C}$. Reference 20.

** Locations:

I - Control, on Savannah River, above Steel Creek mouth.

II - On Savannah River, $20 \mathrm{ft}$ below Steel Creek.

III - On Savannah River, 100 yards below Steel Creek.

IV - On 3ávannah River, 0.6 milo below Steel C.rpek.

$V$ - On Savannah River, one mile below Location IV.

VI - On Savannah River, one mile below Location $V$.

$t$ Percent of distance across stream from right bank, facing upstream. 
TABLE 13

Maximum Temperature Increases Caused by the Savannah River Plant in the Savannah River*

Criterion

Maximum temperature below

SRP after mixing

Maximum temperature increase

Maximum mixing zone

(\% of cross-sectional area)

$\%$ of surface area
South Carolina Maximum Standard

$32.2^{\circ} \mathrm{C}\left(90^{\circ} \mathrm{F}\right) \quad 29.4^{\circ} \mathrm{C}$

$2.8^{\circ} \mathrm{C}\left(5^{\circ} \mathrm{F}\right) \quad 1.4^{\circ} \mathrm{C}$

$25 \% \quad<20 \%$

$33-1 / 3 \% \quad<25 \%$

* Reference 20. Calculated using classified information for two reactors discharging to the river, at minimum river flow. 
TABLE 14

Chronology of Surveys Conducted by the Academy of Natural Sciences of Philadelphia on the Savannah River (1951-1976)

\begin{tabular}{|c|c|c|c|c|c|c|c|}
\hline Survey No. & Survey & Dates & Reac & tor & $5 i$ & 0 & eration* \\
\hline $\begin{array}{l}1 \\
2\end{array}$ & 1951: & $\begin{array}{l}\text { June } 25 \text { - July } 14 \\
\text { Oct. } 15 \text { - Nov. } 31\end{array}$ & $\begin{array}{l}\text { None } \\
\text { None }\end{array}$ & & & & \\
\hline $\begin{array}{l}3 \\
4\end{array}$ & 1952: & $\begin{array}{l}\text { Jan. } 9-31 \\
\text { May } 5-22\end{array}$ & $\begin{array}{l}\text { None } \\
\text { None }\end{array}$ & & & & \\
\hline 5 & 1954: & Aug. $15-30$ & $\mathbf{R}$ & $\mathbf{P}$ & L & & \\
\hline $\begin{array}{l}6 \\
7\end{array}$ & $\begin{array}{l}\text { 1955: } \\
\text { 1956: }\end{array}$ & $\begin{array}{l}\text { Aug. } 24 \text { - Sept. } 7 \\
\text { May } 6-22\end{array}$ & $\begin{array}{l}R^{* *} \\
R\end{array}$ & $\begin{array}{l}P \\
P\end{array}$ & $\begin{array}{l}\mathrm{L} \\
\mathrm{L}\end{array}$ & $\begin{array}{l}\mathrm{K} \\
\mathrm{K}\end{array}$ & $\begin{array}{l}C^{* *} \\
C\end{array}$ \\
\hline $\begin{array}{l}8 \\
9\end{array}$ & 1960: & $\begin{array}{l}\text { May } 23 \text { - June } 4 \\
\text { Aug. } 31 \text { - Sept. } 15\end{array}$ & $\begin{array}{l}\mathrm{R} \\
\mathrm{R} * *\end{array}$ & $\begin{array}{l}P \\
P\end{array}$ & $\begin{array}{l}\mathrm{L} \\
\mathrm{L}\end{array}$ & $\begin{array}{l}\mathrm{K} \\
\mathrm{K}\end{array}$ & $\begin{array}{l}\mathrm{C} \\
\mathrm{C}\end{array}$ \\
\hline $\begin{array}{l}10 \\
11\end{array}$ & 1965: & $\begin{array}{l}\text { May } 30-\text { June } 8 \\
\text { Sept. } 21-30\end{array}$ & & $\begin{array}{l}\mathrm{P} \\
\mathrm{P}\end{array}$ & $\mathrm{L}$ & $\begin{array}{l}\mathrm{K} \\
\mathrm{K}\end{array}$ & $\begin{array}{l}\mathrm{C} \\
\mathrm{C}\end{array}$ \\
\hline $\begin{array}{l}12 \\
13\end{array}$ & 1968: & $\begin{array}{l}\text { May } 27 \text { - June } 5 \\
\text { Aug. } 24 \text { - Sept. } 2\end{array}$ & & $P$ & & $\begin{array}{l}\mathrm{K} \\
\mathrm{K}\end{array}$ & $\begin{array}{l}c \\
C\end{array}$ \\
\hline $\begin{array}{l}14 \\
15\end{array}$ & 1972: & $\begin{array}{l}\text { May } 22 \text { - June } \\
\text { Sept. 13-22 }\end{array}$ & & $\begin{array}{l}P \\
P\end{array}$ & & $\begin{array}{l}\mathrm{K} \\
\mathrm{K}\end{array}$ & $\begin{array}{l}\mathrm{C} \\
\mathrm{C}\end{array}$ \\
\hline 16 & 1976: & Aug. $10-16$ & & $P$ & & $\mathrm{~K}$ & $\mathrm{C}$ \\
\hline
\end{tabular}

* R reactor discharged into Lower Three Runs Creek until 1958 then discharged into Par Pond until it was shutdown in 1964;

$P$ reactor discharged into. Steel Creek until 1963, then discharged into Par Pond;

$L$ reactor discharged into steel Creek until it was placed on stand-by in 1968;

$\mathrm{K}$ reactor discharges into Pen Branch Creek;

$C$ reactor discharges into Four Mile Creek

** Reactor up for part of survey. 
including similar substrates, current velocities and river contours. There should be shallow water and beaches for collecting (particularly for seining $f i s h$ ) and the area should be workable during high and low water conditions.

The Savannah River stations were all located in slow-moving, meandering sections of the river. The river bed consisted mostly of sand, with mud and silt in the pools and backwater areas. There were no large rocks in the river bed, although there were some limestone outcroppings in the area. The largest of these was Blue Bluff, located about $1 / 4 \mathrm{mile}(0.4 \mathrm{~km})$ downstream from Four Mile Creek (Figure 5). A considerable amount of floating and partially submerged debris was present at all stations, which provided increased surface area in the shallow, photosynthetic region of the river. After the completion of Clarks Hill Dam in 1953 there were noticeable changes in the productivity of the Savannah River stations. These changes included increased algal, invertebrate and fish diversities, as discussed in Chapter III.

The major Savannah River stations were numbered $1,3,5$ and 6 , as shown in Figure 5. These stations were used for all comprehensive surveys since 1951. A descriptive summary of the Savannah River stations is given in Table 15.

Station 1 (Figure 6) was located on a straight portion of the river at Mile 160.7 (formerly Mile 175.1), and was above any possible discharge from the Savannah River Plant. Station 1 included all of the dikes on the left bank* and the opposite area on the right bank. The right bank was a gentle slope with overhanging willows. A stone revetment had been built along part of the right bank, and a small stream entering at the downstream boundary. There were sandy beaches between the left bank dikes. At this point the river flowed almost due south.

Station 3 was ecologically very similar to Station 1 . It was located on a straight section of the river at Mile 143.9 (formerly $157.5)$, about 6 miles $(9.6 \mathrm{~km}$ ) downstream from Four Mile Creek (Figure 7). There were dikes with sandy beaches along the left bank, and the right bank was moderately steep and overhung with willows: There was a stone revetment near the right downstream boundary, and a small stream entered along the right bank.

Station 5 was originally located on a bend in the river at Mile 149.5 (Figure 8). Despite superficial differences from Stations 1 and 3 , the ecological habitats were quite similar at Station 5. Sandy beaches and a considerable amount of fallen debris at station 5 provided habitats similar to the sandy, shallow areas between dikes at stations 1 and 3 .

* Bank sides were determined by facing downstream. 
TABLE 15

Descriptive Summary of Stations Used by the Academy of Natural Sciences of Philadelphia for Surveys on the Savannah River

\begin{tabular}{|c|c|c|c|c|}
\hline Station & Location & Survey & Numbers & Description \\
\hline 1 & $\begin{array}{ll}\text { Mile } & 160.7 \\
\text { (old } & 175.1 \text { ) }\end{array}$ & $1-16$ & 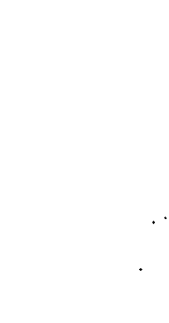 & $\begin{array}{l}\text { Dikes and sandy beaches } \\
\text { on L. bank. Gentle } \\
\text { slope with stone revetment } \\
\text { and small stream on } \\
\text { R. bank. Overhanging } \\
\text { willows, straight } \\
\text { section of river. }\end{array}$ \\
\hline 3 & $\begin{array}{cl}\text { Mile } & 143.9 \\
\text { (old } & 157.5)\end{array}$ & $1-16$ & . & $\begin{array}{l}\text { Dikes and sandy beaches } \\
\text { or L. bank. Fairly steep } \\
\text { R. bank with stone revet- } \\
\text { ment and small stream. } \\
\text { Overhanging willows, } \\
\text { straight section of river. }\end{array}$ \\
\hline $\begin{array}{l}5 \\
(01 d)\end{array}$ & $\begin{array}{l}\text { Old Mile } \\
149.5\end{array}$ & $1-7$ & & $\begin{array}{l}\text { Sandy beaches on both } \\
\text { banks with small stream } \\
\text { on L. bank. Much debris. } \\
\text { Curved section of river, } \\
\text { with steep outer banks. }\end{array}$ \\
\hline $\begin{array}{l}5 \\
\text { (new) }\end{array}$ & $\begin{array}{ll}\text { Mile } & 135.8 \\
\text { (old } 149.5)\end{array}$ & $8-16$ & & $\begin{array}{l}\text { Similar to old Station } 5 \\
\text { Sandy beaches with small } \\
\text { stream on L. bank. Much } \\
\text { debris. Curved section } \\
\text { of river with steep outer } \\
\text { banks. }\end{array}$ \\
\hline 6 & $\begin{array}{l}\text { Mile } 123.1 \\
\text { (old } 134.5 \text { ) }\end{array}$ & $1-16$ & . & $\begin{array}{l}\text { Sandy beaches on curve of } \\
\text { river. Slough on R. bank } \\
\text { designated Station } 6 \mathrm{~B} \text { as } \\
\text { opposed to river proper } \\
\text { at 6A. Much debris. }\end{array}$ \\
\hline
\end{tabular}




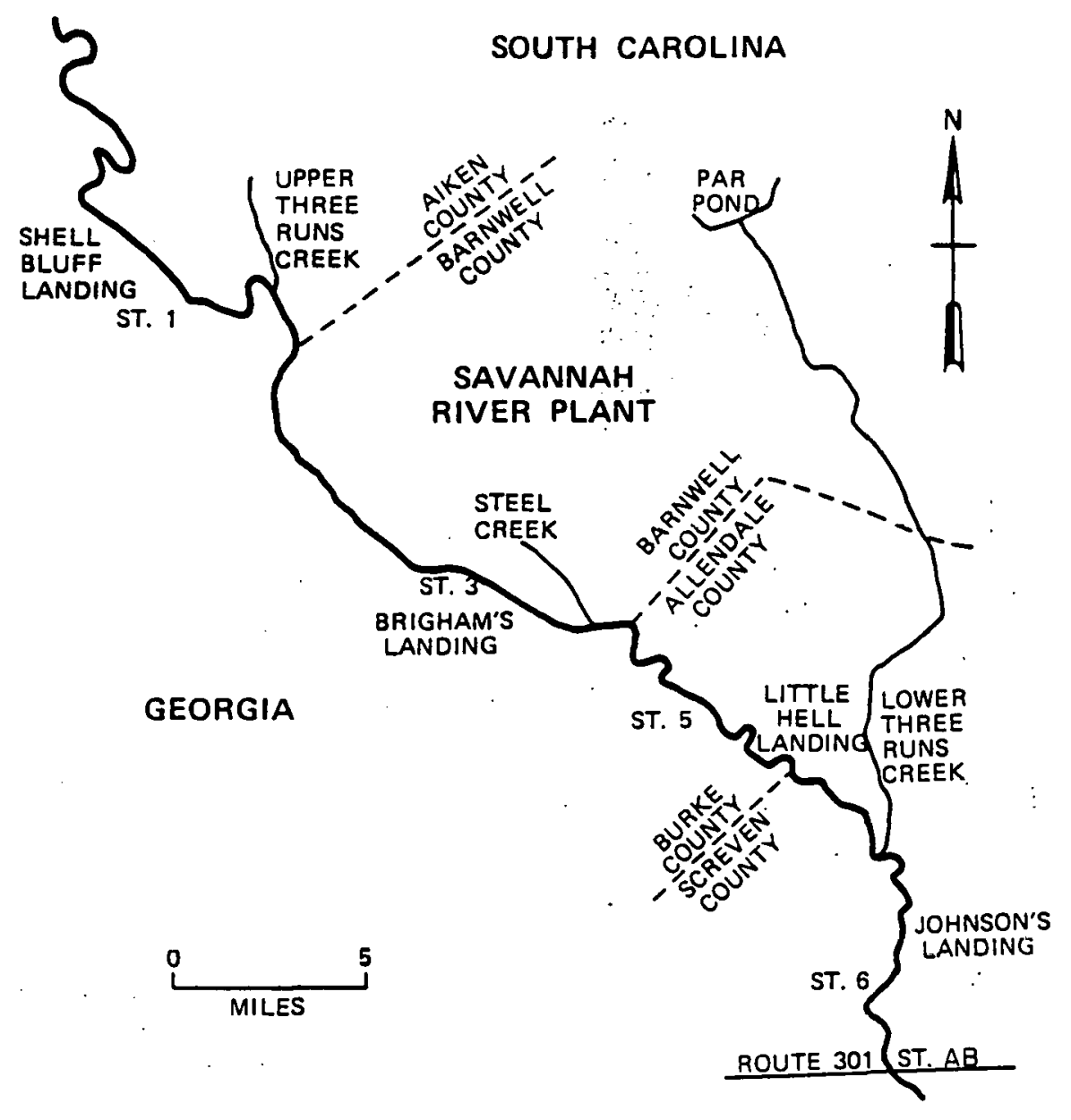

Figure 5. Survey Stations Used By the Academy of Natural Sciences of Philadelphia on the Savannah River (1951-1976). 


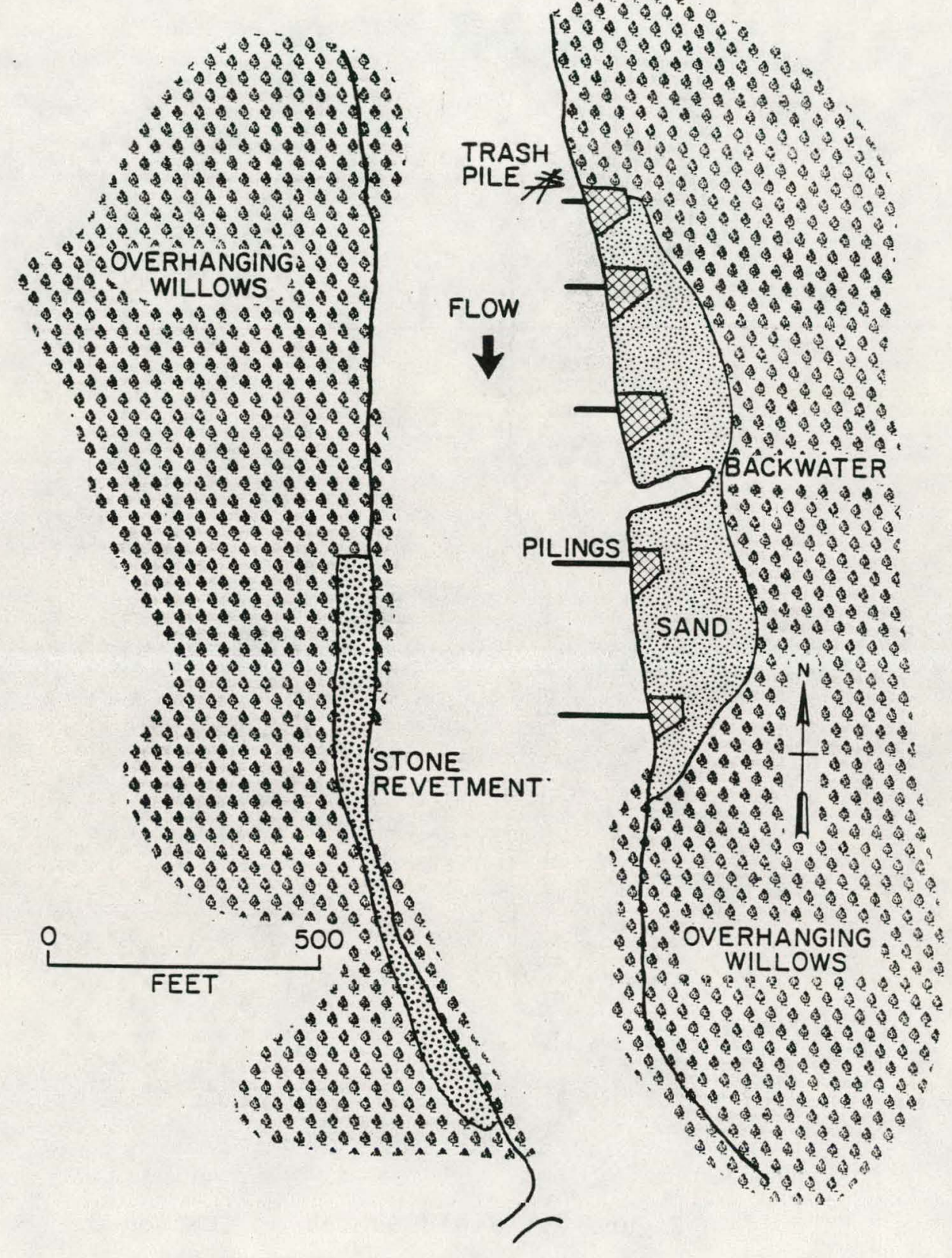

Figure 6. Field Sketch of Station 1.

References 1-9. 


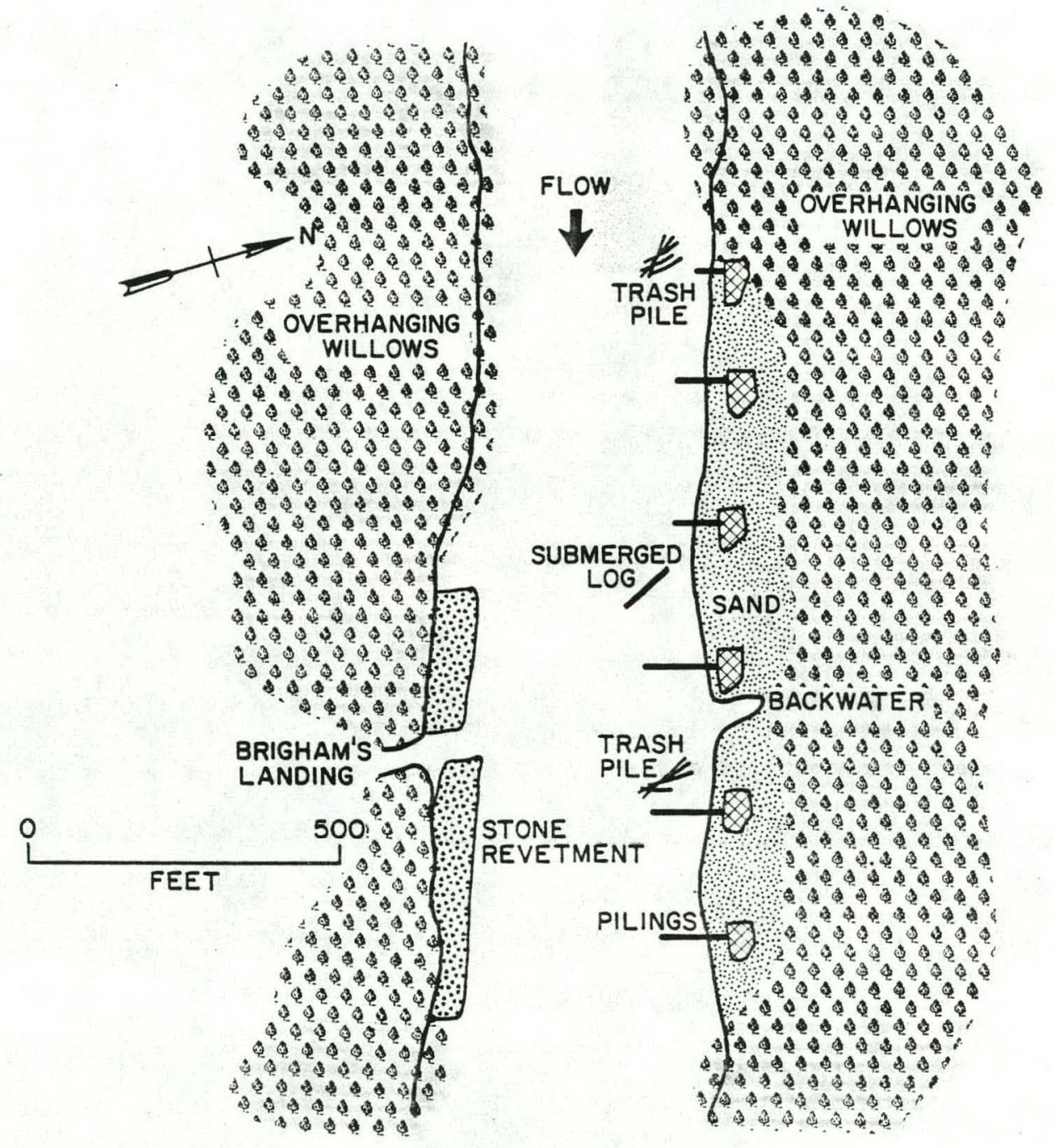

Figure 7. Field Sketch of Station 3.

References 1-9. 


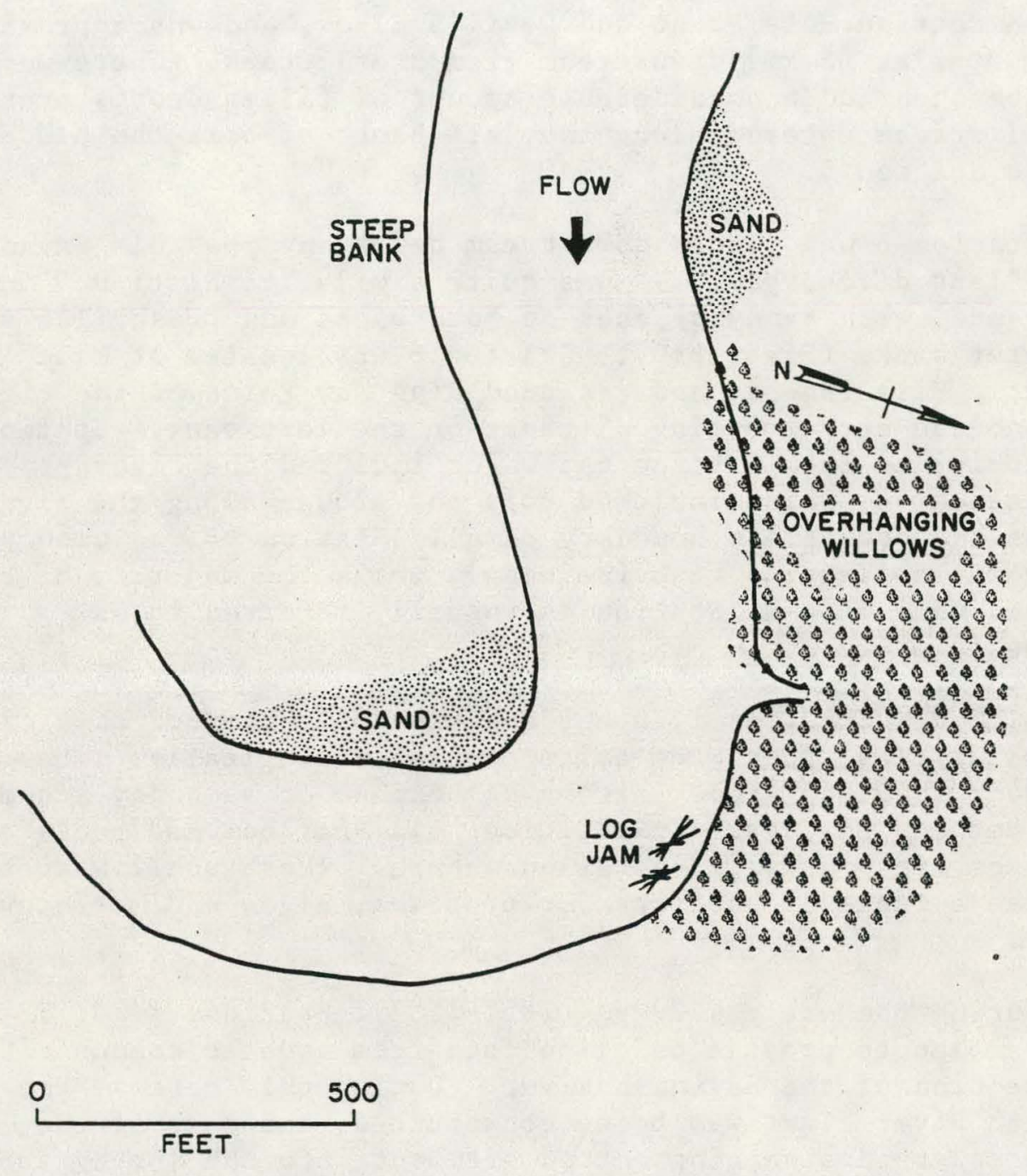

Figure 8. Field Sketch of Original Station 5. References $1,2$. 
In 1958 a dredging project was initiated by the U. S. Corps of Engineers. This project altered the river channel and caused Station 5 to become an oxbow. Station 5 was relocated to Mile 135.8 (formerly 149.5) for the 1960 surveys, and for the subsequent surveys. The new Station 5 was so similar in appearance to old Station 5 that the two were difficult to distinguish without a map. New Station 5 (Figure 9) was located on a bend in the river between Catfish Hole Point and Devil's Elbow, and was approximately 5 miles $(8 \mathrm{~km})$ downstream from Steel Creek. There were sandy beaches and a considerable amount of fallen debris present. A small stream entered along the left banks of both the old and the new Station 5 .

Station 6 was placed downstream below any possible Savannah River Plant discharges. It was quite similar to Station 5 in appearance, with sandy beaches on both banks and trashpiles along the outer banks (Figure 10). Station 6 was located at Mile 123.1 (formerly Mile 134.5), and included Ring Jaw Point on the right bank and the corresponding distance on the left bank. Station 6 was subdivided into Station $6 \mathrm{~A}$, which included the river proper, and Station $6 \mathrm{~B}$, which included only the slough along the right bank at the downstream boundary of 6A. Station $6 \mathrm{~B}$ was used primarily for collecting fish (seining), while the majority of collections were made at Station $6 \mathrm{~A}$ (usually referred to as Station 6).

Although Stations $1,3,5$, and 6 had a number of physical dissimilarities, they were quite similar ecologically. They all had sandy, shallow areas, either as beaches or as sandy accumulations between pilings. In addition, all stations had pools and backwater areas as well as fallen debris. These shallow areas provided a range of habitats for protozoa, algae and macroinvertebrates.

During the early surveys (1951-1952), Stations 1, 3, 5, and 6 were sampled to provide baseline data from aquatic communities in this section of the Savannah River. During this period, the Savannah River Plant was being constructed, and none of the reactors were discharging heated effluent into the survey area. After 1954, Station 5 received heated effluent from $P$ and $L$ reactors by way of Steel Creek, and indirectly from $\mathrm{K}$ reactor which discharged into Pen Branch, a tributary of Steel Creek. Station 3 received effluent from $C$ reactor by way of Four Mile Creek. The effluent from $P$ reactor was redirected into Par Pond in 1963, and L reactor was placed on stand-by in 1968. Reactors C and $\mathrm{K}$ are still in operation.

During the period that $\mathrm{K}, \mathrm{L}$, and $\mathrm{C}$ reactors were all operational, the temperature increase observed in the Savannah River caused by Savannah River Plant operations was usually no 


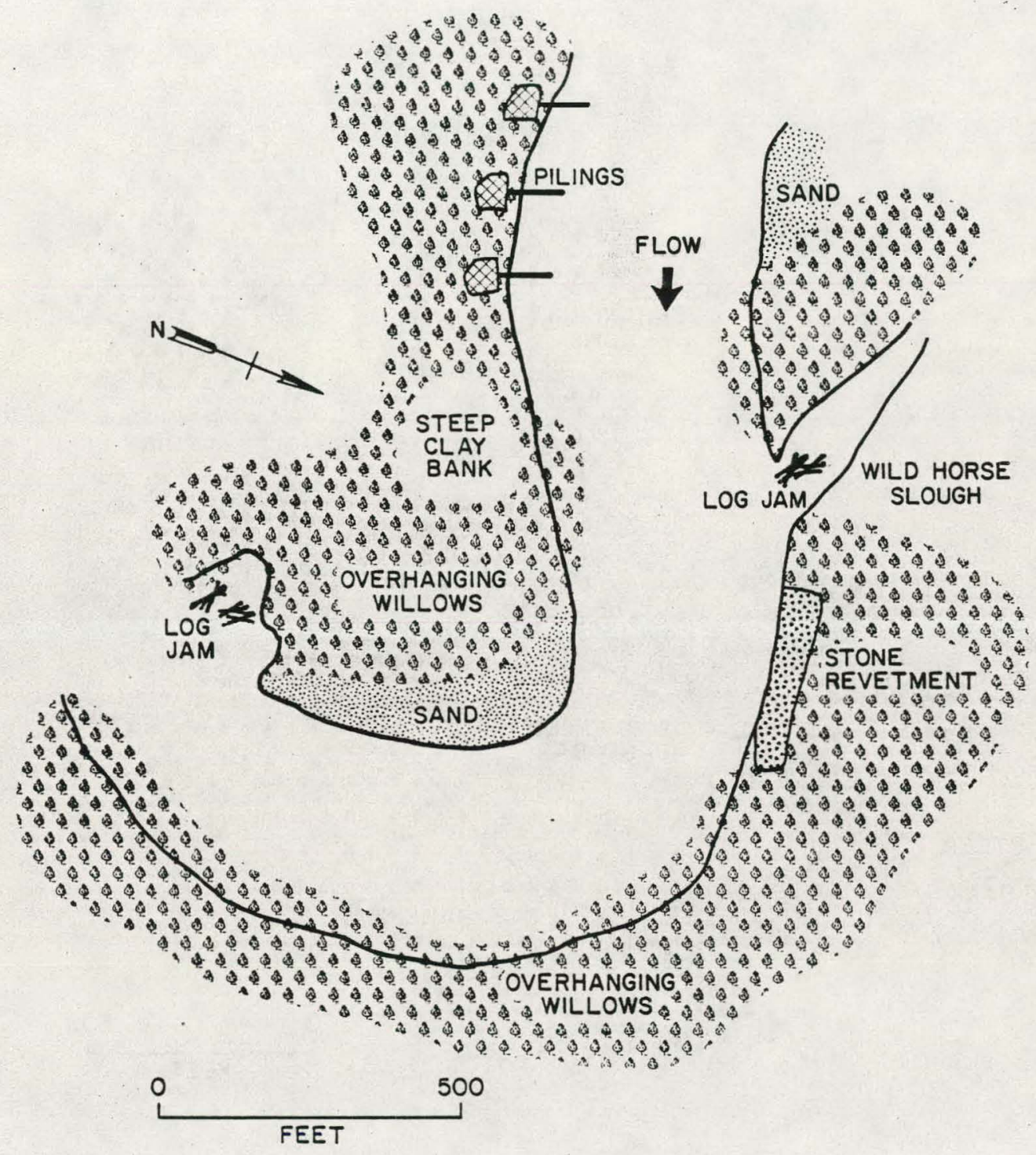

Figure 9. Ficld Sketch of Relocated Station 5.

References 3 through 9. 


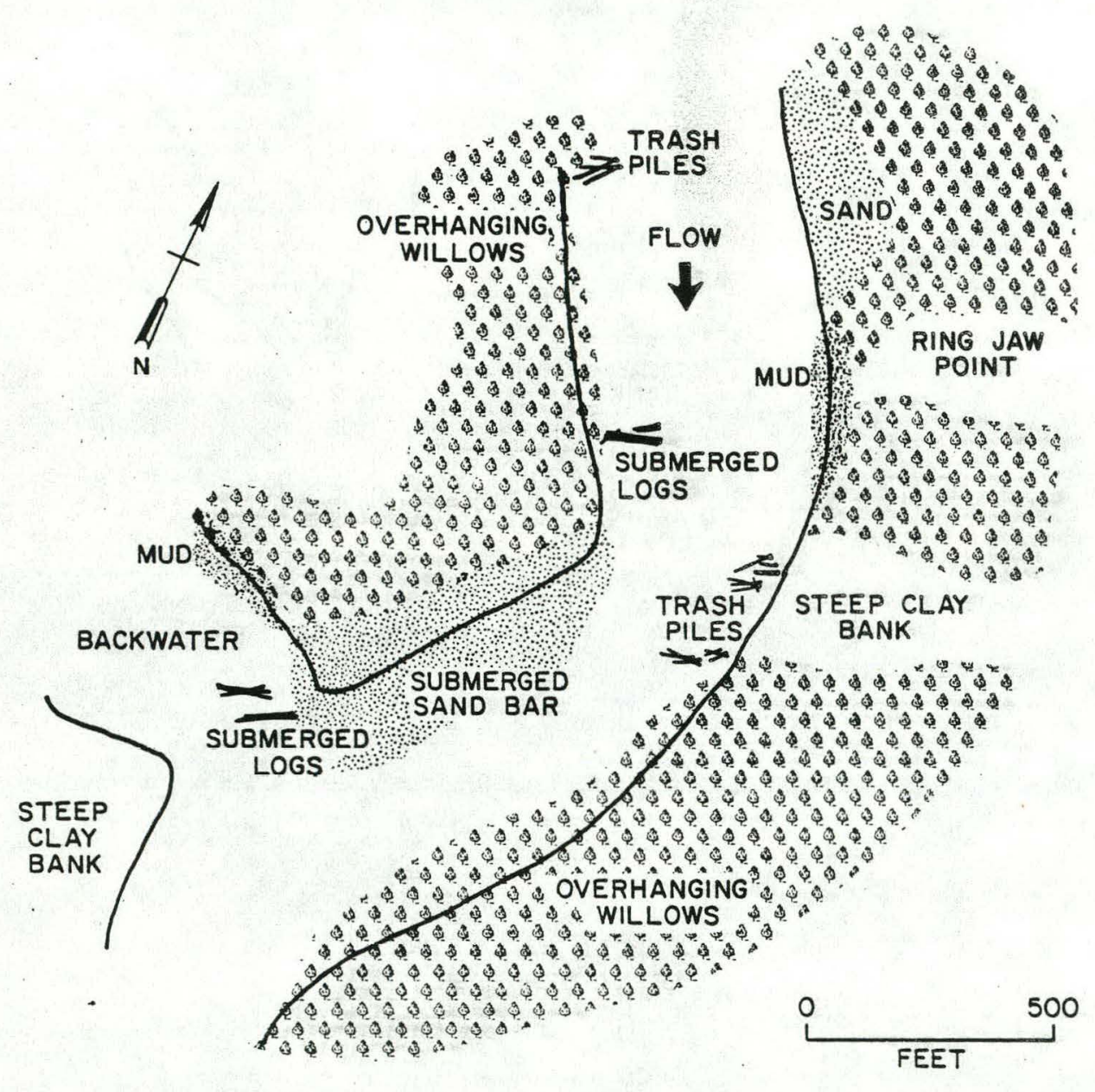

Figure 10. Field Sketch of Station 6 .

References 1 through 9 . 
greater than $5^{\circ} \mathrm{C}\left(2.8^{\circ} \mathrm{C}\right.$; Table 13 , Chapter IV). The thermal plume from Steel Creek was obliterated when the river passed a meander. The water temperatures at both Stations 3 and 5 were essentially homogeneous.

One additional station, Station $A B$, was located on the Savannah River, and was used for quarterly diatom surveys. This station was located at Mile 118.7, upstream from the Allendale Bridge on Rt. 301. Station $A B$ was used as a reference station, and was situated well downstream from any Savannah River Plant thermal sources. The station was ecologically similar to Stations $1,3,5$ and 6 , with debris along the left bank, and overhanging vegetation along the right bank. Station $A B$ was not used for any of the comprehensive river surveys, and field sketches of the station were not provided in any of the Academy survey publications.

\section{CHAPTER VI. METHODS}

The Academy of Natural Sciences of Philadelphia attempted to sample all river habitats qualitatively during the major river surveys to insure that most of the biota in the river were collected on each survey. Survey field teams usually consisted of a phycologist, an entomologist, an ichthyologist, a water chemist, a protozoologist, an invertebrate zoologist, and field assistants. Except where noted, the collecting, preservation and identification techniques were consistent for all major river surveys.

Much of the sampling was done by boats and, because of the size of the sampling area, took several weeks to complete. The first samples collected at each station were water samples for physical, chemical, and bacterial analyses. The methods for these analyses are summarized in Table 16. The station averages for each water chemlscry measurement are given by survcy number in Appendix B.4.

After the water samples were collected, several days were spent at each station sampling the major biological communities and populations in the river.: Collecting was initiated at the downstream boundary of each station and proceeded upstream. All organisms, except protozoa, were sorted and preserved in the field, then transported to the Academy's laboratories for identification and incorporation into permanent collections. Protozoa were identified in the field laboratory because they cannot be preserved satisfactorily.

The river communities and populations were sampled qualitatively from a wide variety of habitats. Separate species lists were developed for algae and diatoms, insects, microinvertebrales, 
TABLE 16

Summary of Methods used for Physical, Chemical, and Bacteriological Analyses of Savannah River Water Samples*

\section{Measurement}

Alkalinity
a) Methyl Orange
b) Phenolphthalein
c) Bicarbonate
d) Carbonate

Bacteriological
a) Total bacteria
c) Coliform

Bicarbonate

Carbon Dioxide

Chlorides

Conductivity

Hardness
a) Total
b) Calcium
c) Magnesium

\section{Method}

a) Methyl orange titration

b) Phenolphthalein titration

c) Calculated from M.O.\& P Alkalinities

d) Calculated from M.O.\&.P Alkalinities a) Membrane filtration + M-TGE broth incubation

b) Membrane filtration + M-endo broth incubation

Calculated from Alkalinity

Calculated from $\mathrm{pH}$ and Alkalinity

Mohr titration, Silver Nitrate/Potassium Chromate titration

Specific conductivity meter (Cond. bridge)

a) Compleximetric or EDTA titration, procedure and reagents from Betz \& Co., Philadelphia, Pennsylvania, or calculated from Atomic Absorpton data

b) C. 4 Calcium hardness method, Betz\& Co. reagents and procedure or calculated from $\dot{A}$. A. data

c) Betz \& Co. reagents and procedure or calculated from A. A. data

Metals
a) Calcium
b) Iron
c) Magnesium
d) Manganese
e) Potassium
f) Sodium

a) Measured on Perkin Elmer Model 303 Atomic Absorption Spectrophotometer or calculated from Hardness data.

b) Phenanthroline method or measured on A. A.

c) Calculated from Total and Calcium Hardness, or measured on A. A.

d) Measured on A. A.

e) Measured on A. A.

f) Measured on A. A.

* All methods are from Standard Methods 23-26 unless indicated: 
TABLE 16 (Contd)

Measurement

Nitrogen
a) Ammonia
b) Kjeldah 1
c) Nitrate
d) Nitrite

Oxygen
a) Biological Oxygen Demand
b) Chemical oxygen Demand
c) Dissolved Oxygen pH

Phosphate
a) Total
b) Ortho

\section{Silica}

Solids (Residue)
a) Total
b) Dissolved
c) Fixed
d) Suspended
e) Volatile

\section{Sulfate \\ Temperature \\ Traneparancy \\ Turbidity}

Method

a) Direct Nesslerization method, automated Phenate method 27 or measured with an Orion Ammonia electrode

b) Kjeldahl method or measured with a Technicon Auto Analyzer II

c) Phenoldesulphonic acid method, Cadmium Reduction Auto Analyzer 27 and Spectrophotometric Brucine method

d) Diazotization methód, and Diazotization using Auto Analyzer 27

a) 5-day B.O.D. Test

b) Microdichromate Reflux Method 28

c) Azide modification of the Winkler test

La Motte Co., Baltimore, Maryland $\mathrm{pH}$ Kit or Orion $401 \mathrm{pH}$ Meter

a) Persulfate digestion/Ascorbic acid method

b) Colorimeteric Stannous Chloride method, Ascorbic Acid method, and Auto Analyzer (Ascorbic Acid) Method 27

Colorimeters silicomolybdate method (intermediate range) and Auto Analyzer (Molybdate - Reactive Silica)

a) Filtration/gravimetric method

b) Filtration/gravimetric method

c) Filtration/gravimetric method

d) Filtration/gravimetric method

e) Filtration/gravimetric method

Turbidimetric method

Field measurement using mercury-filled glass thermometer Black and white Serchi dise

Jackson Candle method, photometric measurement at $420 \mu \mathrm{m}$ using standard suspendion from Harleco Co., Philadelphia Pennsylvania, or Hach 2100 Turbidimeter, Standardized with formazin suspension 
protozoa, and fish. A summary of these data averaged for each station by survey number, are presented in Appendix B.l.

Algae were sampled from shallow and deep water, logs and twigs, stones, moss and rootlets, soft mud, and any other substrate present inside the station boundaries. All samples were placed in $17 \mathrm{ml}$ vials or small jars and examined in the laboratory to separate nonliving material from the sample. The samples were preserved with formalin, ethanol or Transeau's Fixative ( 6 parts water: 3 parts $95 \%$ ethanol: 1 part formalin). Diatoms were cleared and washed prior to examination. All organisms were identified to species or taxa. Diatom taxa represented by fewer than six specimens were not considered to be established in the samples, and were excluded from the species lists.

Diatoms were also collected from glass slide substrates that had been suspended for two weeks at Stations 1,6 , and $A B$ using Catherwood Diatometers. 29 The diatometers were placed near the right and left banks at each station, and collections were made biweekly by Savannah River Plant personnel. The colonized slides were mailed to the Academy for processing and quantitative species identifications. Complete quantitative counts were made quarterly on representative slides from the biweekly samples. The diatom data in the Savannah River Laboratory data base are segregated into Diatom data (from quarterly quantitatives counts) and Diatom Taxonomy Data (from qualitative major river surveys).

Protozoa were collected using an aspirator bottle or a plastic tube connected to a rubber bulb. Approximately 15 to 20 half-pint jars were collected at each station. Samples were kept in an insulated container or wet bag, and were transported to the laboratory within one hour to avoid loss of sensitive species. At the laboratory the samples were placed near a light source and allowed to settle. Subsamples were taken from the miniscus and surface of the sediments near and away from the light source. Species were identified with the aid of conventional stains or by using a Phase Contrast microscope, which eliminated the necessity of stains. Only species represented by 6 or more specimens per slide, or species identified in 3 out of 4 subsamples were considered to be established and were included in the species lists.

Macroinvertebrates were collected from a variety of habitats, including sand bars, clay banks, mud flats, stone revetments, tributary mouths, pilings, floating debris and snags. Slow moving and sedentary forms were collected by hand, while other forms were collected using dip nets, dredges, mesh screens and bottom scrapers (Needham Scraper). Some specimens were placed directly in vials with alcohol or formalin. Substrate and plant materials were taken to the laboratory for sorting under a dissecting microscope. 
Insects were placed in vials containing 50 percent alcohol, then transferred to 70 percent alcohol for storage. Tendipedid larvae were mounted directly on microscope slides. Arthropods, annelids and poriferans were preserved in 70 percent alcohol. All other macroinvertebrates were collected alive, then narcotized to prevent excessive contraction in death, before being fixed and preserved in alcohol.

Fish were collected by a number of methods. Initially, seines were used in backwater areas, along with hoop nets, gill nets, wire traps and hook and line fishing techniques. After 1952, rotenone was also used for collecting fish. Potassium permanganate was applied after the collections were made to detoxify the rotenone and to restrict its effects to the desired area. Fish were preserved with 10 percent formalin and transferred to 40 percent isopropyl alcohol for storage.

\section{CHAPTER VIII. SCOPE OF THE SAVANNAB RIVER LABORATORY DATA BASE}

The Savannah River Laboratory version of the 25-year data base is stored on IBM $370 / V S$ direct access devices, using local FORTRAN/VSAM interface routines. It is expected, therefore, that parties interested in analyzing these data will require the assistance of Savannah River Laboratory Computer Science personnel in retrieving and reformatting selected data items. This chapter will describe the content of the data base. Appendix A alphabetically lists the taxa for which data are available. Appendix $B$ gives an overview of the Savannah River Survey results in conveniently available formats.

There are four major data sets in the data base:

1) A taxonomic nomenclature coding structure;

2) Presence/absence data, organized by

- Each Station and Date for all Taxa

- Each Taxon for all Stations and Dates;

3) Diatometer Taxa frequency counts, organized by

- Each Station and Date for.all Taxa

- Each Taxon for all Stations and Dates;

4) Water Quality physical and chemical species concentrations, organized by

- Each Station and Date for all species

- Each species for all Stations and Dates. 
Each of these data sets are described in the following subsections.

\section{A. Savannah River Taxonomy}

The Savannah River taxonomic coding structure uses three distinct labels for each item of nomenclature:

1) An Accession Number identifies each specific class of organism. This unique number is never changed, and is treated in all computer programs as a surrogate for the organism's taxonomic identity. The Accession Number is maintained as a nonreuseable JSS Key Access Number (KAN).

2) Each Accession Number (KAN) is correlated to appropriate biological taxonomic nomenclature from the Savannah River data. This is the data portion of the KAN record in the Taxonomic Data set.

3) Taxonomic data are placed into a classification hierarchy from Phylum to Forma, comprised of 18 possible levels (Table 17).

The Key portion of the JSS taxonomic data set is comprised of the 18 hierarchical levels concatenated into a 72 byte Key. Unused levels, and levels below the one being defined, are zero filled. The Key field values may be changed to alter the natural presentation order of taxonomy, but such changes do not alter the assigned KAN. For example, the organism "Alasmidonta arcula (Lea)" with the following taxonomy:

$\begin{array}{ll}\text { Phylum } & \text { Mollusca } \\ \text { Class } & \text { Bivalvia } \\ \text { Subclass } & \text { Paleoheterodonta } \\ \text { Order } & \text { Unionoida } \\ \text { Superfamily } & \text { Unionacea } \\ \text { Family } & \text { Unionidae } \\ \text { Subfamily } & \text { Anodontinae }\end{array}$

might be represented by a Key of:

phy. subp cls. subc ord. subo grp. ser. supf fam. subf

01400000020001000100000000000000010001000100

trb. grp. gen. subg spc. subs frm. (not used)

000000000100000000100000000000000000

where numeric codes have been recorded in corresponding hierarchical positions.

In short, the Accession Number creates a computer identity for each organism in the Savannah River. As we alter the taxonomic 
TABLE 17

Taxonomic Hierarchy used for the Classification of the Savannah River Biological Data

Taxonomic Level

Phylum/Division

Subphylum/Subdivision

Class

Subclass

Order

Ssborder

Group

Series

Superfamily

Family

Subfamily

Tribe

Group

Genus

Subgenus

Species

Subspecies/Variety

Forma
Key Positions

$1-4$

5-8

9-12

$13-16$

$17-20$

$21-24$

25-28

29-32

33-36

37-40

41-44

45-48

49-52

53-56

57-60

$61-64$

65-68

69-72 
cross references for the computer's Accession Numbers, the printed names for organisms may change; however, their computer identity will not. This system allows the taxonomic nomenclature to be updated when future changes or revisions are necessary to maintain a current and accurate taxonomy. A listing of the taxonomic accession numbers is included in Appendix A. Whenever possible, the accession number should be used when requesting data for a particular organism or group of organisms.

The taxonomic data may be formatted in a variety of ways. A complete listing of the organisms identified from the Savannah River during the entire survey period is extensive. This lengthy list may be condensed into similar orders, classes or phyla, for easier interpretation. One example of such a condensation is presented in Appendix B.1. Here the data are grouped into major biological subsets, and graphed by station to show the total number of species identified for each survey.

\section{B. Presence/Absence Data}

The Presence/Absence data are binary values associated with each accession number, at each of up to four stations, at each of the 16 survey dates. An example of one possible Presence/Absence data format is given in Appendix B.2.

The surveys and stations for which data are available are as follows :

$\begin{array}{llr}\text { 1951: } & \text { spring } & 1,3,5,6 \\ & \text { fall } & 1,3,5,6 \\ \text { 1952: } & \text { spring } & 1,3,5,6 \\ & \text { fall } 1,3,5,6 \\ \text { 1954: } & \text { fall } 1, & 1,6 \\ 1955: & \text { fall } & 1,3,5,6 \\ 1956: & \text { spring } 1,3,5,6 \\ \text { 1960: } & \text { spring } 1,3,5,6 \\ & \text { fall } 1,3,5,6 \\ 1965: & \text { spring } 1,3,5,6 \\ & \text { fall } 1,3,5,6\end{array}$

1968: spring $1,3,5,6$

fall $1,3,5,6$

1972: spring $1,3,5,6$

fall $1,3,5,6$

1976: Eall 1,3,5,6

\section{Diatometer Data}

The Diatometer data are recorded as counted frequency values associated with each accession number, at each of up to four stations, for each of four seasons, in each of the 24 study years. These data are different from the diatom taxonomy data, which include only species listings. The diatometer data may be formatted in a number of different ways. One example is presented in Appendix B.3. 
The studies and diatometer numberst for which data are available are as follows:

\begin{tabular}{|c|c|c|c|c|c|}
\hline 1953: & fall & 2,4 & & & \\
\hline 1954: & $\begin{array}{l}\text { winter } \\
\text { spring } \\
\text { summer }\end{array}$ & $\begin{array}{l}2,4 \\
2,3 \\
1,3\end{array}$ & 1962: & $\begin{array}{l}\text { winter } \\
\text { spring } \\
\text { summer }\end{array}$ & $\begin{array}{l}2,4,8 \\
2,4,8 \\
2,4,8\end{array}$ \\
\hline & Eall & 2,3 & & fall & $2,4,8$ \\
\hline 1955: & winter & 2,3 & 1963: & winter & $2,4,8$ \\
\hline & spring & 1,3 & & spring & $2,4,8$ \\
\hline & summer & 2,3 & & summer & $2 ; 4,8$ \\
\hline & 1 & 2,4 & & fall & $2,4,8$ \\
\hline 1955: & winter & 2,3 & 1963: & winter & $2,4,8$ \\
\hline & $\begin{array}{l}\text { spring } \\
\text { summer }\end{array}$ & $\begin{array}{l}1,3 \\
2,3\end{array}$ & & $\begin{array}{l}\text { spring } \\
\text { summer. }\end{array}$ & $\begin{array}{l}2,4,8 \\
2,4,8\end{array}$ \\
\hline & fall & 2,4 & & fall & $2,4,8$ \\
\hline 1956: & winter & 2,4 & 1964: & winter & $1,4,8$ \\
\hline & $\begin{array}{l}\text { spring } \\
\text { sumerer }\end{array}$ & $\begin{array}{l}2,4 \\
2,4\end{array}$ & & $\begin{array}{l}\text { spring } \\
\text { summer }\end{array}$ & $\begin{array}{l}2,4,8 \\
2,4,8\end{array}$ \\
\hline & fall & 2,4 & & fall & $2,4,8$ \\
\hline 1957: & winter & 2,4 & 1965: & winter & $2,4,9$ \\
\hline & $\begin{array}{l}\text { spring } \\
\text { summer }\end{array}$ & $\begin{array}{l}1,4 \\
2,4\end{array}$ & & $\begin{array}{l}\text { spring } \\
\text { summer }\end{array}$ & $\begin{array}{l}2,4,9 \\
2,4,8\end{array}$ \\
\hline & fall & 1,4 & & $\mathrm{fall}$ & $2,4,8$ \\
\hline 1958: & winter & 2,4 & 1966: & winter & $2,4,8$ \\
\hline & ring & 1,4 & & spring & $1,4,8$ \\
\hline & fall & $\begin{array}{l}2,4 \\
2,4\end{array}$ & & fall & $2,4,8$ \\
\hline 1959: & winter & $2,4,8$ & 1967: & winter & $2,4,8$ \\
\hline & spring & $2,4,8$ & & spring & $2,4,9$ \\
\hline & summer & $2,3,8$ & & summer & $2,4,8$ \\
\hline & $f$ & $2,4,8$ & & fall & $2,4,8$ \\
\hline 1960: & winter & $2,3,8$ & 1968: & winter & $2,4,9$ \\
\hline & ing & $2,4,8$ & & spring & $2,4,9$ \\
\hline & mer & $2,4,8$ & & sumue $\mathrm{I}$ & $2,4,8$ \\
\hline & & $1,4,8$ & & fall & $2,4,8$ \\
\hline 961 & winter & $2,4,8$ & 1969: & winter & $2,4,8$ \\
\hline & $\ln \xi$ & $1,4,8$ & & spring & $2,4,8$ \\
\hline & ner & $2,4,8$ & & summer & $2,4,8$ \\
\hline & & $2,4,8$ & & fall & $2,4,8$ \\
\hline
\end{tabular}
1970: winter $2,4,8$ spring $2,4,8$ summer $2,4,8$ fall $2,4,8$

1971 : winter $2,4,8$ spring $2,4,8$ summer $2,4,8$ fall $2,4,8$

1971 : winter $2,4,8$ spring $2,4,8$ summer $2,4,8$ fall $2,4,8$

1972: winter $2,4,8$ spring $2,4,8$ summer $2,4,8$ fall $2,3,8$

1973: winter $2,4,8$ spring $2,4,9$ summer $2,4,8$ fall $2,4,8$

1974: winter $2,4,8$ spring $2,4,9$ summer $2,4,8$ fall $2,4,8$

1975: winter $2,4,8$ spring $2,4,8$ summer $2,4,8$ fall $2,4,8$

1976: winter $2,4,8$ spring $2,4,8$ summer $2,4,8$ fall $2,4,8$

* Two diatometers were placed at each station:

$\begin{array}{cl}\text { Station 1: } & \begin{array}{l}\text { Diatometer } 1 \text { near the left bank } \\ \text { Diatometer } 2 \text { near the right bank }\end{array} \\ \text { Station } 6: & \begin{array}{l}\text { Diatometer } 3 \text { near the left bank } \\ \text { Diatometer } 4 \text { near the right bank }\end{array} \\ \text { Station } \triangle B: & \begin{array}{l}\text { Diatometer } 8 \text { near the left bank } \\ \text { Diatometer } 9 \text { near the right bank }\end{array}\end{array}$




\section{Chemical Data}

The chemical data are real values of the concentration of the following suite of water-quality parameters:

Alkalinity, Methyl Orange (mg/L as $\mathrm{CaCO}_{3}$ )

(abbreviation)

Alkalinity, Phenylthphlein (mg/L as $\mathrm{CaCO}_{3}$ )

ALKAMO

Alkalinity, Carbonate (mg/L)

ALKALP

Alkalinity, Bicarbonate (mg/L)

$\mathrm{CO} 3$

Bacteria, Coliform Count ( $c 01 / 100 \mathrm{~mL})$

$\mathrm{HCO} 3$

Bacteria, MPN (cel1/100 mL)

Bacteria, Plate Count ( $\mathrm{col} / \mathrm{mL}$ )

Bacteria, Total Count ( $\mathrm{col} / \mathrm{mL})$

Bacteria, Viable Count ( $c 01 / \mathrm{mL})$

Carbon Dioxide (mg/L)

Dissolved Oxygen (mg/L)

Chloride (mg/L)

Specific Conductivity ( $\mu$ mho at $25^{\circ} \mathrm{C}$ )

COLCTN

MPNCTN

PLACTN

TOTCTN

VIACTN

$\mathrm{CO} 2$

DO

CL

Hardness, Total (mg/L as $\mathrm{CaCO}_{3}$ )

SPCOND

Hardness, $\mathrm{Ca}$ (mg/L as $\mathrm{CaCO}_{3}$ )

HARD

Hardness, $\mathrm{Mg}\left(\mathrm{mg} / \mathrm{L}\right.$ as $\mathrm{CaCO}_{3}$ )

$\mathrm{CACO} 3$

Calcium (mg/L)

MGCO3

Iron (mg/L)

Magnesium (mg/L)

$\mathrm{CA}$

Manganese (mg/L)

FE

MG

MN

Potassium (mg/L)

$\mathrm{K}$

Sodium (mg/L)

Ammonia (mg/L)

Total Kjeldah 1 Nitrogen (mg/L)

NA

Nitrate (mg/L)

NH3-N

TKN

Nitrite (mg/L)

NO3-N

NO2-N

Biological Oxygen Demand (mg/L)

BOD

Chemical Oxygen Demand (mg/L)

COD

Total Phosphorus. (mg/L)

TOTP

Ortho-Phosphorus (mg/L)

P04-P

Silica (mg/L)

SIO2

Total Solids (mg/L)

Total Dissolved Solids (mg/L)

TS

Fixed Solids (mg/L)

TDS

Suspended Solids (mg/L)

FIXR

Volatile Solids (mg/L)

SS

$\mathrm{pH}$

VS

Temperature $\left({ }^{\circ} \mathrm{C}\right)$

$\mathrm{PH}$

Sulfate (mg/L)

TEMP

SO4

Transparency (in.)

CLEAR

Turbidity (mg/L)

TURB

The data are available at up to each of four stations in each of the 16 survey years. Examples of Chemical data are presented in Appendix B.4. These examples indicate two ways the data may be formatted. 
The studies and stations for which data are available are as follows:

$\begin{array}{lll}\text { 1951: } & \text { spring } & 1,3,5,6 \\ \text { 1952: } & \text { fall } & 1,3,5,6 \\ & \text { fpring } & 1,3,5,6 \\ \text { fall } & 1,3,5,6 \\ \text { 1955: } & \text { fall } & 1,3,5,6 \\ 1956: & \text { spring } & 1,3,5,6 \\ 1960: & \text { spring } & 1,3,5,6 \\ & \text { fall } & 1,3,5,6 \\ 1965: & \text { spring } & 1,3,5,6 \\ & \text { fall } & 1,3,5,6 \\ 1968: & \text { spring } & 1,3,5,6 \\ & \text { fall } & 1,3,5,6 \\ 1972: & \text { spring } & 1,3,5,6 \\ & \text { fall } & 1,3,5,6 \\ 1976: & \text { fall } & 1,3,5,6\end{array}$


1. Savannah River Biological Survey. South Carolina and Georgia. June 1951 - May 1952. Final Report for the E. I. du Pont de Nemours \& Company, Savannah River Plant. 282 pp. Academy of Natural Sciences of Philadelphia. Philadelphia (1953).

2. Savannah River Biological Survey. South Carolina and Georgia. August 1954. Progress Report for the E. I. du Pont de Nemours \& Company, Savannah River Plant. 62 pp. Academy of Natural Sciences of Philadelphia. Philadelphia (1955).

3. Savannah River Biological Survey. South Carolina and Georgia. August - September 1955, May 1956. Progress Report for the E. I. du Pont de Nemours \& Company, Savannah River Plant. 210 pp. Academy of Natural Sciences of Philadelphia. Philadelphia (1957).

4. Savannah River Biological Survey. South Carolina and Georgia. May - June and August - September 1960. Report for the E. I. du Pont de Nemours \& Company, Savannah River Plant. 128 pp. Academy of Natural Sciences of Philadelphia. Philadelphia (1961).

5. Savannah River Biological Survey. South Carolina and Georgia. May - June and September 1965. Report for E. I. du Pont de Nemours \& Company, Savannah River Plant. 151 pp. Academy of Natural Sciences of Philadelphia. Philadelphia (1967).

6. Savannah River Biological Survey. South Carolina and Georgia. May and August 1968. Report for E. I. du Pont de Nemours \& Company. 130 pp. Academy of Natural Sciences of

Philadelphia. Philadelphia (1970).

7. Sumnary of Studies on the Savannah River, $1951-1970$, for E. I. du Pont de Nemours \& Company. 47 pp. Academy of Natural Sciences of Philadelphia. Philadelphia (1970).

8. Savannah River Biological Survey. South Carolina and Georgia. May and September 1972. Report for E. I. du Pont de Nemours \& Company. 161 pp. Academy of Natural Sciences of Philadelphia. Philadelphia (1974). 
9. Savannah River Biological Survey. South Carolina and Georgia. August 1976. Progress Report for E. I. du Pont de Nemours \& Company. 118 pp. Academy of Natural Sciences of Philadelphia. Philadelphia. Philadelphia (1977).

10. R. Patrick (ed.). Thermal Effects on the Savannah River. 166 p. Report No. 81-11FF, Academy of Natural Sciences of Philadelphia. Philadelphia (1981).

11. R. Patrick, J. Cairns, Jr., and S. S. Roback. An ecosystematic study of the fauna and flora of the Savannah River. Proc. Ac. Nat. Sci.. Philadelphi) 118, 109 (1967).

12. J. L. Cooley and E. G. Farnworth. Environmental Resource Inventory of the Savannah River Basin. 244 pp. U. S. Army Corps of Engineers, Savannah District. Savannah, Georgia (1974).

13. "Water Use Classification and Water Quality Standards." Rules of the Environmental Protection Division. Georgia Department of Natural Resources. Atlanta (1973).

14. Water Quality Investigation of the Savannah River Bas in in Georgia. Environmental Protection Division, Georgia Department of Natural Resources. Atlanta (1974).

15. Augusta Water Quality Survey. 83 pp. Georgia Water Quality Board. Atlanta (1970).

16. Dredging records from the Savannah River 1964-1973, U. S. Army Corps of Engineers, Records Holding Area, Huntington Is land, Savannah, Georgia. (unpublished)

17. Report on the Federal - State - Industry Cooperative Savannah River Water Quality Studies. $1956-1965.173$ pp. U. S. Department of Health, Education \& Welfare, Public Health Service, Savannah River Advisory Board. Atlanta (1967).

18. A Report on Pollution in the Middle Reach of the Savannah River. Gerogia - South Carolina. 161 pp. Report No. TS03-71-208-003, U. S.e. Environmental Protection Agency, Southeast Water Laboratory, Technical Services Program. Athens (1972).

19. Water Resources Data for South Carolina. U. S. Department of the Interior, Geological Survey, Water Resources Division. Columbia, SC (1951-1977). 
20. Waste Management Operations, Savannah River Plant, Aiken, South Carolina. Draft Environmental Statement. Energy Research and Development Administration Report ERDA-1537. Washington, DC (1976).

21. T. M. Langley and W. L. Marter. The Savannah River Plant Site. 175 pp. USAEC Report DP-1323, E. I. du Pont de Nemours and Co., Savannah River Laboratory. Aiken, SC (1973).

22. Public Health Service Drinking Water Standards. 1962.

U. S. Department of Health, Education \& Welfare, Public Health Service. Washington, DC (1962).

23. Standard Methods for the Examination of Water, Sewage and Industrial Wastes (10th ed). American Public Health Association. New York (1955).

24. Standard Methods for the Examination of Water and Wastewater (11th ed.) 626 pp. American Public Health Association. New York (1960).

25. Standard Methods for the Examination of Water and Wastewater (12th ed.) 769 pp. American Public. Health Association. New York (1965).

26. Standard Methods for the Examination of Water and Wastewater (13th ed.). 874 pp. American Public Health Association. New York (1971).

27. Water Quality Criteria. 594 pp. U. S. Environmental Protection Agency, Environmental Studies Board. Washington, DC. (1972).

28. A. M. Jirka and J. Carter. "Microsemi-automated analys is of surface and wastewaters for chemical oxygen demand." Analyt. Chem. 47, 1397 (1975).

29. R. Patrick, M. H. Hohn, and J. H. Wallace. "A new method for determining the pattern of the diatom flora." Acad. Nat. Sci. Philadelphia Notulae Nat. 259, 1 (1954).

30. R. J. Brown, W. R. Jacobsen, E. W. Rabon, and L. J. Tilly. Thermal Discharges from the Savannah River Plant. USAEC Report DPST-72-428, E. I. du Pont de Nemours \& Co., Savannah River Laboratory. Aiken, SC (1972). 
Appendix A. Savannah River Taxonomic Accession List

A. 1. Algae*

A. 2 Fishes

A. 3 Macro-invertebrates *

A. 4 Protozoa

A. 5 Unidentified Taxa

* Synonyms are included at the ends of these subgroups: 


\section{APPENDIX A. SAVANNAH RIVER TAXONOMIC ACCESSION LIST}

1. ALGAE

NOMENCLATURE

ACCESSTOK NO.

DIVISION:

Bacillariophyta

Chlorophyta

3087

3000

comophyta

Cyanophyta

Rhodophyta

CIASS :

Bacillariophyceae

Charophyceae

cyanophyceae

Euchlorophyceae

Rhodophyceae

Ulothxicophyceae

Xanthophyceae

Zygophyceae

ORDER:

Achnanthales

Acrochaetiales

Bacillariales

Biddulphiales

Chaetophorales

Chamaesiphonales

Charales

Chlorococcales

Chroococcales

Coinpsopogonales

Epithemiales

Eunotiales

Eupodiscales

Fragilariales

Naviculales

Memalionales

Nostocales

Oedogoniales

Siphonocladales

stigonematales

3079

3204

3088

3074

3159

3001

3205

3025

3080

3055

3118

3211

3149

3096

3026

3.161

3075

3002

3166

3207

3144

3113

3089

3103

3123

3216

3176

3033

3036

3199 


\section{APPENDIX A. SAVANKAH RIVER TAXONOMIC ACCESSION IIST}

1. ALGAE

MOIENCI.ATURE

ACCESSION NO.

ORDER:

Surirellales

Tetrasporales

Tribonematales

Ulotrichales

Ulvales

Vaucheriales

zygnematales

3154

3021

3084

3052

3081

3056

FAMILY :

Achnanthaceae

Acrochaetiaceae

Anaulaceae

Audouineliaceae

Bactrachospermaceae

Biddulphiaceae

Chaetophoraceae

Chamaesiphonaceae

Characeae

Chroococcaceae

Clad ophoraceae

clastidiaceae

Coccomyraceae

Compsopogonaceae

Coscinodiscaceas

cylindrocapsaceae

Cymbelíaceae

Desmidiaceae

En tomoneidaceae

Entophysalidaceae

Epithemiaceae

Eunotiaceae

Fragilariaceae

Gomphonemaceae

Hydrodictyaceae

lemaneaceae

Mesotaeniaceae

Microsporaceae

Naviculaceae

3119

3212

3214

3217

3099

3027

3162

3167
3037

3164

3003

3208

3090

3044

3136

3057

3142

3173

3145

3114

3104
3139

3006

3219

3065

3046

3124 


\title{
APPENDIX A. SAVANKAH RIVER TAXONOMIC ACCESSION IIST
}

1. ALGAE

\section{MOMENCLATURE}

\section{FAMILY:}

\author{
Nitzschiaceae \\ Hos tocaceae \\ oedogoniacéae \\ oocystaceae \\ Oscillatoriaceae \\ palmellaceae \\ Rivulariaceae \\ Scenedesmaceae \\ Schizomeridaceae \\ Scytonemataceae \\ Stigonemataceae \\ Surirellaceae \\ Tetrasporaceae \\ Thalassiosiraceae \\ Tribonemataceae \\ Ulotrichaceae \\ Vaucheriaceae \\ zygnemataceae
}

GENUS \& SPECIES:

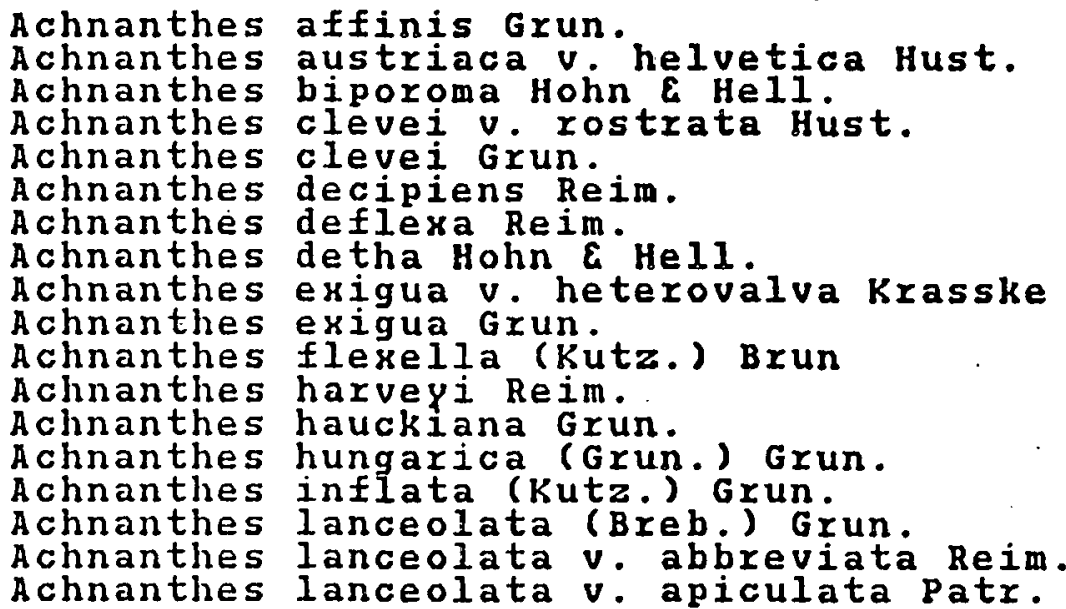




\section{APPENDIX A. SAVANNAH RIVER TAXONOMIC ACCESSION IIST}

1. ALGAE

NOMENCLATURE

\section{GENUS \& SPECIES:}

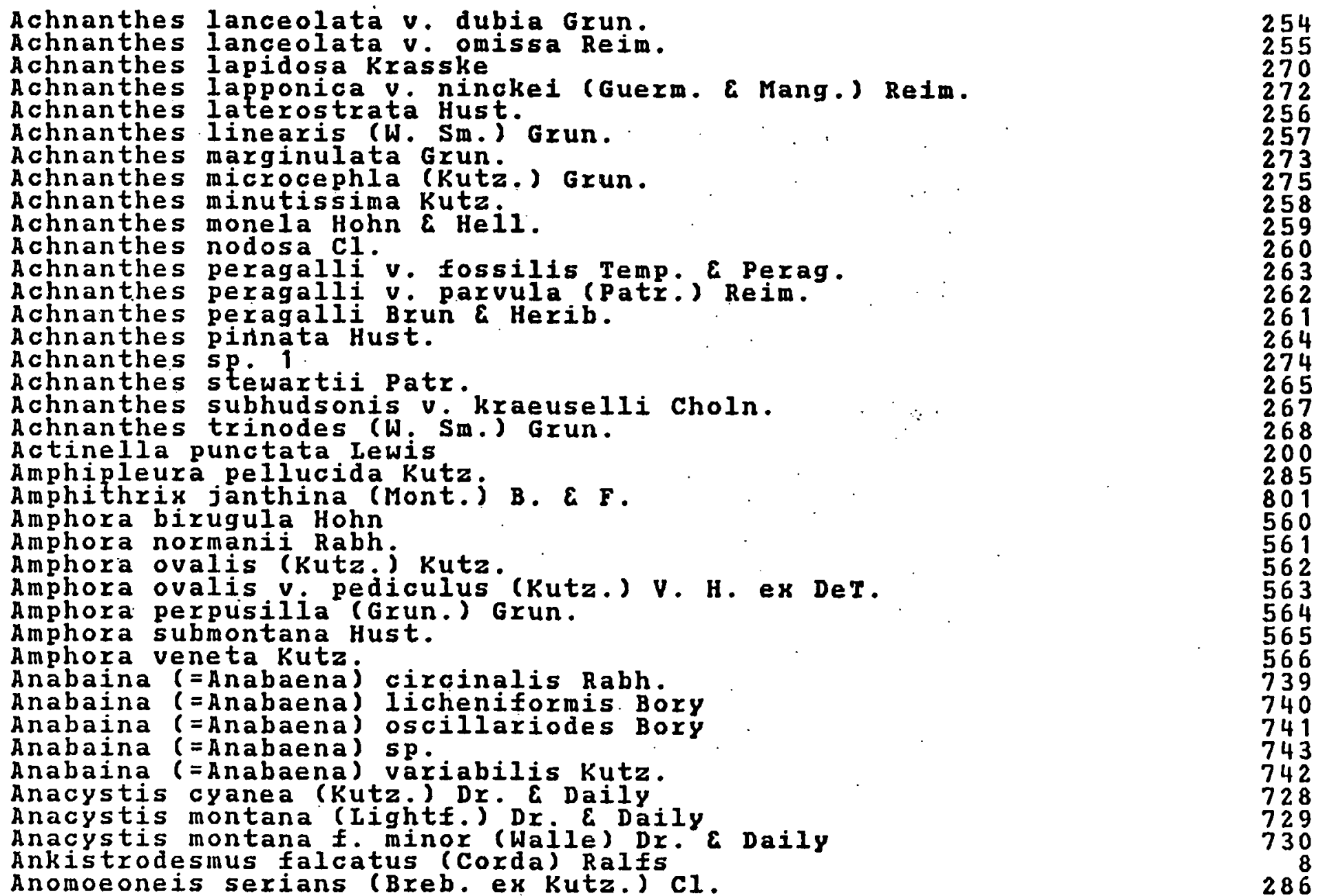

254

70

272

57

58

60

63

61

74

67

68

85

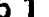

63

65

66

40

43

42

29

286 
APPENDIX A. SAVANKAH RIVER TAXONOMIC ACCESSION IIST

1. ALGAE

NOMENCLATURE

ACCESSION NO.

\section{GENUS \& SPECIES:}

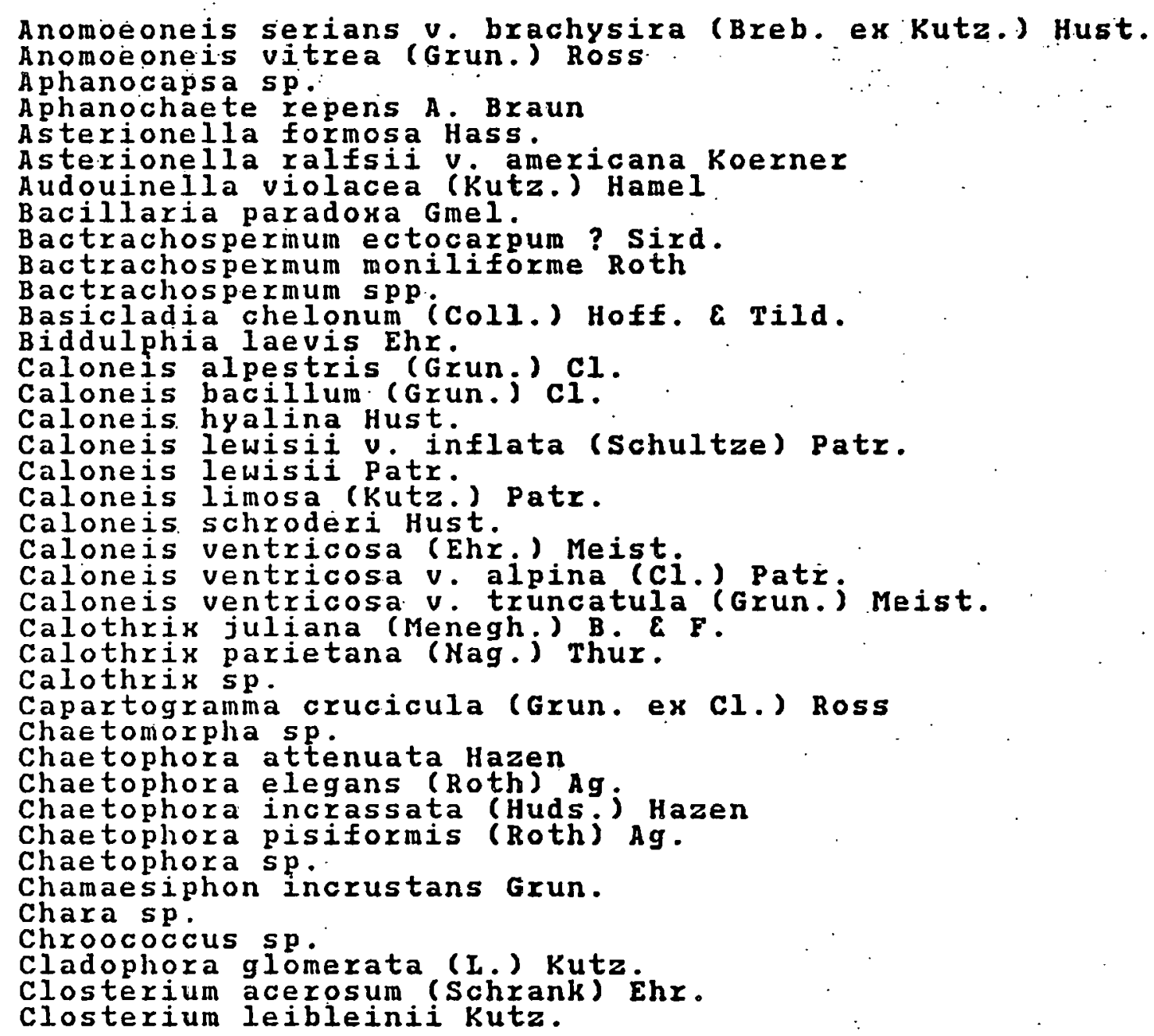


1. ALGAE

NOMEICLATURE

ACCESSIOH 110.

GENUS \& SPECIES:

closterium libellula y interruptum (West $\varepsilon$ West) Donat

Closterium lunula (Mul1, Nitz.

Closterium moniliferum (Bory) Ehr.

Closterium parvulum Maeg.

Closterium sp.

Closterium tumidum Johns.

Closterium venus Kutz.

Cocconeis diminuta pant.

Cocconeis disculus (Schum:) cl.

Cocconeis fluviatilis Wall.

Cocconeis pediculus Ehr.

Cocconeis placentula v. euglypta (Ehr.) cl.

Cocconeis placentula vilineata (Ehr.j v. H.

Cocconeis placentula Ehr.

Cocconeis thumensis A. May.

Coelastrum cambricum Arch.

Coelastrum microsporum Kaeg.

Compsopogon coeruleus (Baib.) Mont.

Cosmarium granatum Breb.

Cosmarium laeve Rabh.

Cosmarium polygonum (Naeg.) Arch.

Cosmarium pseudoconnatum Hordst.

Cosmarium punctulatum v. subpunctulatum (Nordst.) Borg.

Cosmarium pygmaeum Arch.

Cosmarium pyramidatum Breb.

Cosmarium quadratum Ralfs

Cosmarium regnellii Wille

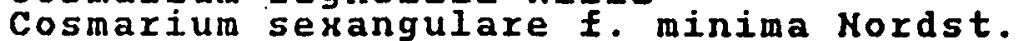

Cosmarium sp.

Cosmarium subcrenatum Hantz.

Cosmarium subprotumidum Nordst.

Cosmarium subspeciosum Nordst.

Cosmarium turpinii Breb.

Cyclotelia atomus Hust.

Cyclotelia cointa (Ehr.; Kutz.

Cyclotelia meneghiniana Kutz.

Cyclotelia pseudostelligera Hust.

Cyclotella stelligera C1. E Grun.

Cyclotelia striata (Kutz.) Grun. 


\section{APPENDIX.A. SAVANNAH RIVER TAXONOMIC ACCESSION IIST}

1. ALGAE

\section{NOMENCIATURE}

ACCESSION NO.

GENUS \& SPECIES:

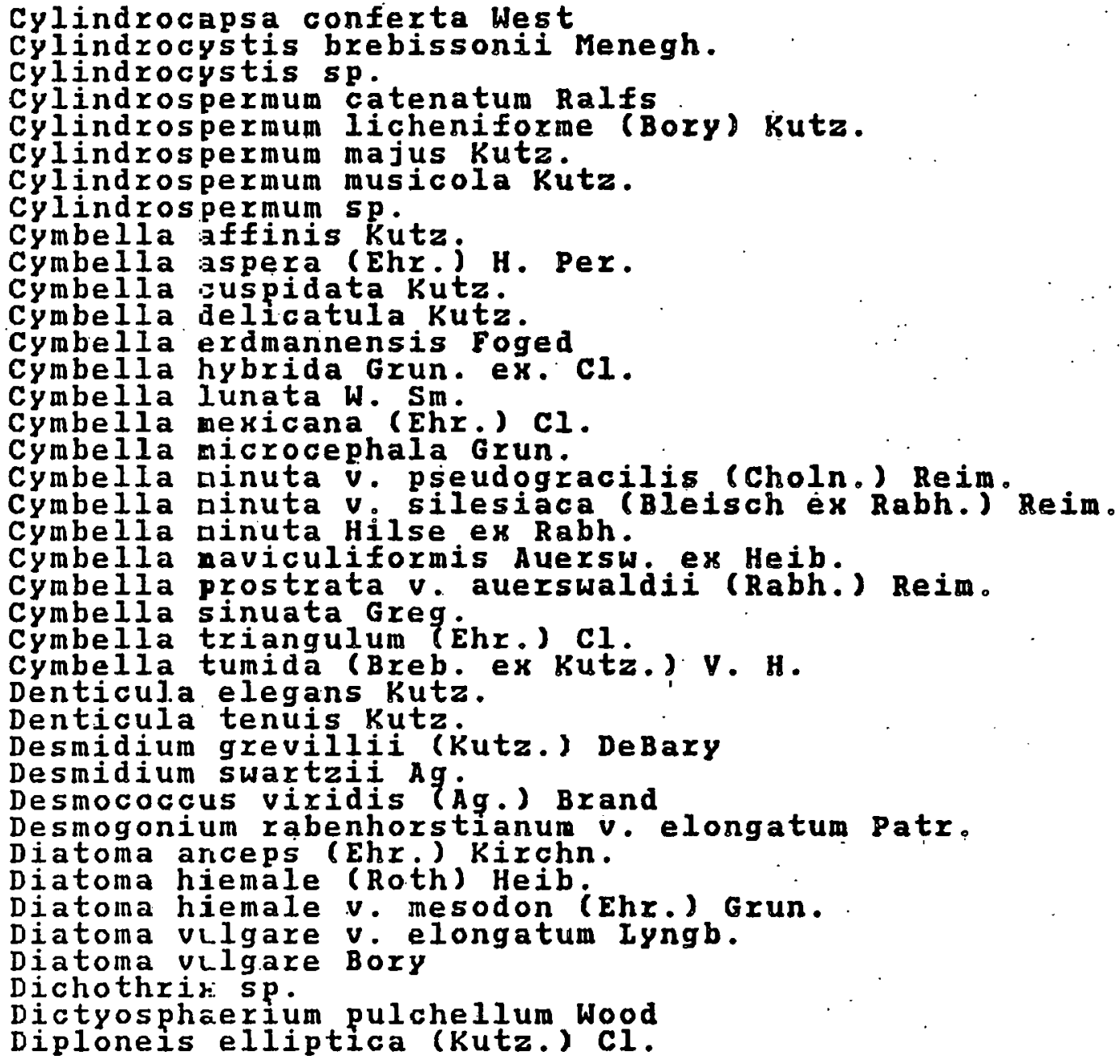

Cymbelia luana (Ehr.) Cl. 


\section{APPENDIX A. SAVANMAH RIVER TAXONOMIC ACCESSION LIST}

1. ALGAE

NOMENCLATURE

ACCESSION NO.

GENUS \& SPECIES:

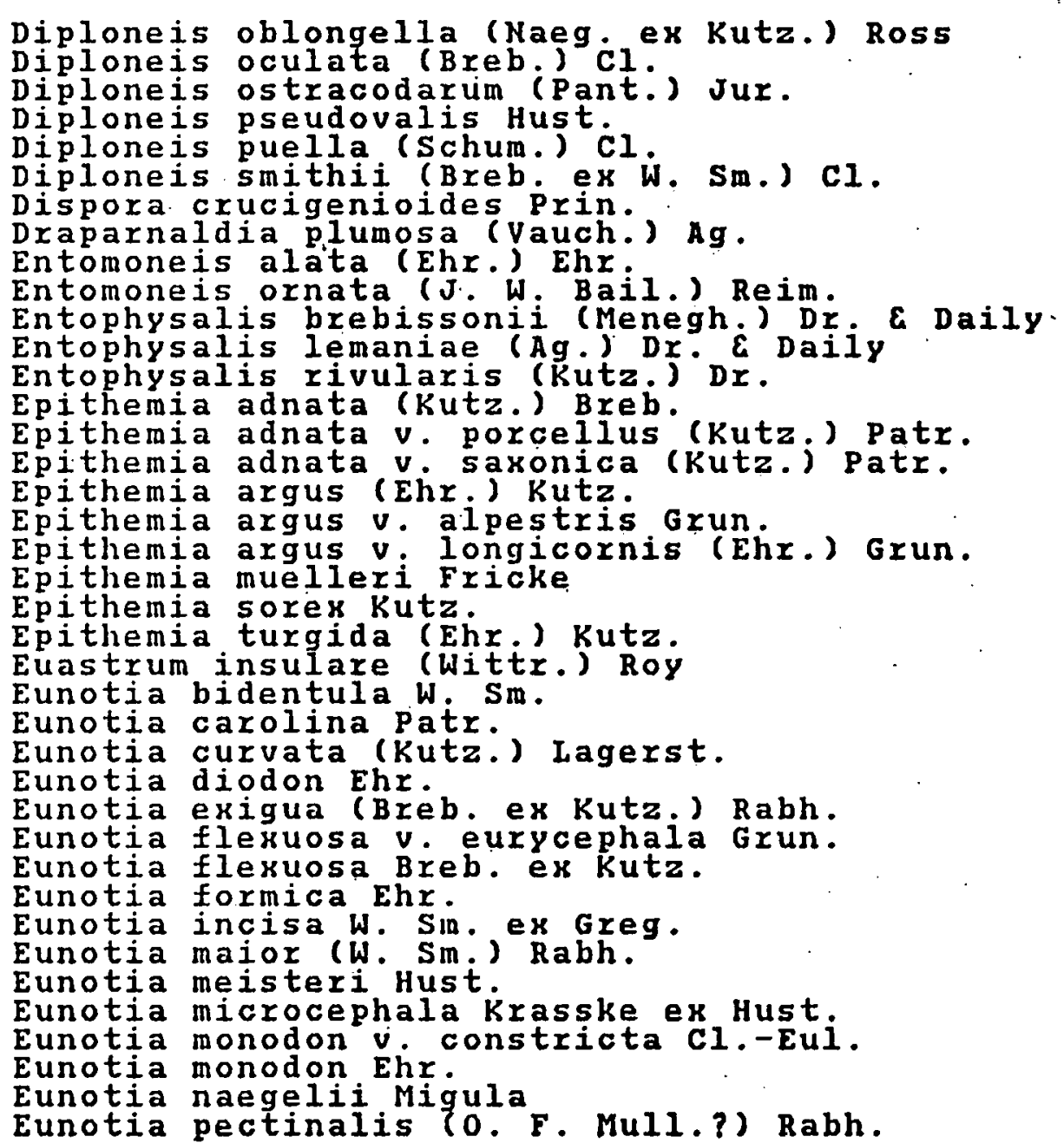

60

618

619
736

737 
1. ALGAE

MOMENCLATURE

ACCESSION NO.

GENUS \& SPECIES :

Eunotia pectinalis $v$. minor (Kutz.) Rabh.

Eunotia pectinalis $v$. undulata (Ralfs) Rabh.

Eunotia perpusilla Grun

Eunotia praerupta v. bidens (Ehr.) Grun.

Eunotia praerupta Ehr

Eunotia quaternaria Ehr.

Eunotia rabenhorstii $v$. monodon Grun.

Eunotia serra v. diadema (Ehr.) Patr.

Eunotia sudetica 0 . Mull.

Eunotia suecica A. Cl.

Eunotia tautoniensis Hust. ex patr.

Eunotia tenelia (Grun.) $\mathrm{ci}$

Eunotia vanheurckii v in

Eunotia

Eunotia zasuminensis (Cabej.) Korn

Fragilaria bicapitata A. Mayer

Fragilaria brevistriata Grun.

Fragilaria capucina v. mesolepta Rabh

Fragilaria constxicta f. stricta (A. Cl.) Hust.

Fragilaria construens (Ehr,) Grun.

Fragilaria construens $v$. binodis (Ehr.) Grun.

Fragilaria construens $v$. pumila Grun.

Fragilaria construens $v$. subsalina Hust.

Fragilaria construens $v$. venter (Ehr.) Grun.

Fragilaria crotonensis Kitton

Fragilaria lapponica Grun.

Fragilaria leptostauron (

Fragilaria pinnata $v$. lancettula (Schum.) Hust.

Fragilaria pinnata $v$. subcapitata Freng.

Fragilaria pinnata Ehr.

Fragilaria spinosa skv.

Fragilaria strangulata (zanon) Hust.

Fragilaria vaucheriae (Kutz.) peters.

Fragilaria virescens Ralfs

Frustulia rhomboides (Ehr.) DeT.

Frustulia rhomboides $v$. amphipleuroides (Grun, ) Cl.

Frustulia rhomboides v. crassinervia (Breb. ex $w$. Śm.) Ross

Frustulia vulgaris (Thwaites) DeT.

Frustulia vulgaris $v$. muscosa skv.

215

216

217

219

218

220

224

233

23

229

225

226

228

153

155

158

161

159

160

162

163

164

165

167

168

166

169

172

170

173

307

308

309

310 
1. ALGAE

NOMENCLATURE

ACCESSION NO.

GENUS \& SPECIES:

Frustulia weinholdii Hust.

Gloeocystis vesiculosa Naeg; cl.

Gomphonema abbreviatum Ag.

Gomphonema acuminatum Ehr.

Gomphonema affine $v$. insigne (Greg.) Andrews

Gomphonema affine kutz.

Gomphonema angustatum (kutz.) Rabh.

Gomphonema angustatum $v$. intermedia Grun.

Gomphonema angustatum $v$. productum Grun.

Gomphonema apuncto J.Wallace

Gomphonema augur Ehr.

Gomphonema borealis $v$. minor Foged

Gomphonema brasiliense Grun.

Gomphonema carolinense Hageist.

Gomphonema clevei Fricke

Gomphonema dichotomum Kutz.

Gomphonema gibba.J. Wallace

Gomphonema gracile Ehr.emend. V. H.

Gomphonema grunowii Patr.

Gomphonema intricatum Kutz.

Gomphonema manubrium Fricke

Gomphonema olivaceoides $v$. hutchinsoniana Patr.

Gomphonema olivaceum (Lyngb.) Kutz.

Gomphonema parvulum Kutz.

Gomphonema rhombicum Fricke

Gomphonema sparsistriata (o. Mull.) Engler

Gomphonema subclavatum (Grun.) Grun.

Gomphonema truncatum $v$. capitatum (Ehr.) Patr.

Gomphonema truncatum Ehr.

Gomphonema turris Ehr.

Gomphonema ventricosum Greg.

Gomphosphaeria wichurae (Hije) Dr a Dail

Gonatozygon pilosum wolle

Gyrosigma acuminatum (Kutz.) Rabh.

Gyrosigma exilis (Grun.) Reim.

Gyrosigma nodiferum (Grun.) Reim.

Gyrosigma scalproides (Rabh.) cl. 
APPENDIX A. SAVANAH RIVER TAXONOMIC ACCESSION IIST

1. ALGAE

NOMENCLATURE

ACCESSION 10.

GENUS \& SPECIES:

Gyrosigma spencerii (Quek.) Grift. G Henfr.

Hannaea arcus (Ehr.) patr.

Hantzschia amphioxys Grun.

Hantzschia virgata (Roper) Grun.

Hapalosiphon fontinalis (Ag.) Born.

Hyalotheca dissiliens (J.E.Sm.) Breb.

Hyalotheca mucosa (Dillw.) Ehr.

Hydrosira triquetra Wall.

Kirchnerielia contorta (Schmidle) Bohlin

Iyngbya aerugineo-caerulea (Kutz.) Gom.

Lyngbya aestuarii (Mert.) Liebmann

Lyngbya bicolor Wood

Iyngbya contorta Lemm.

Iyngbya epiphytica Hieronymus

Iyngbya putealis Mont. ex Gom.

Iyngbya spp.

Lyngbya versicolor (Wartm.) Gom.

Melosira distans v. alpigena Grun.

Melosira granulata (Ehr.) Ralfs

Melosira granulata $v$. angustissima Mull.

Melosira italica (Ehr.) Kutz.

Melosira italica v. multistriata Patr

Melosira italica v. tenuissima (Grun.jMull.

Melosira roeseana Rabh.

Melosira tenella KYg

Melosira undulata (Ehr.) Kutz.

Melosira varians Ag.

Meridion circulare (Grev.) Ag.

Meridion circulare v. constricta (Ralfs) $v$. H.

Merismopedia tenuissima Lemm.

Merismopedia tranquilla (Ehr.) Trevis.

Mesotaenium chlamydosporum DeBary

Mesotaenium degreyii v. breve West

Mesotaenium macrococcum ? (Kutz.)

Microcoleus chthonoplastes (Mert.) Zarard

174
634

634

814

96

95

144

754

755

756

757

758

759

761

Microcoleus irriguus (Kutz.) Dr.

irriguus

762

Microcoleus lyngbyaceus Kutz

Microcoleus paludosus (Kutz; Gom.

Microcoleus vaginatus (Vauch.) Gom. 
1. ALGAE

HOMENCLATURE

GENUS \& SPECIES :

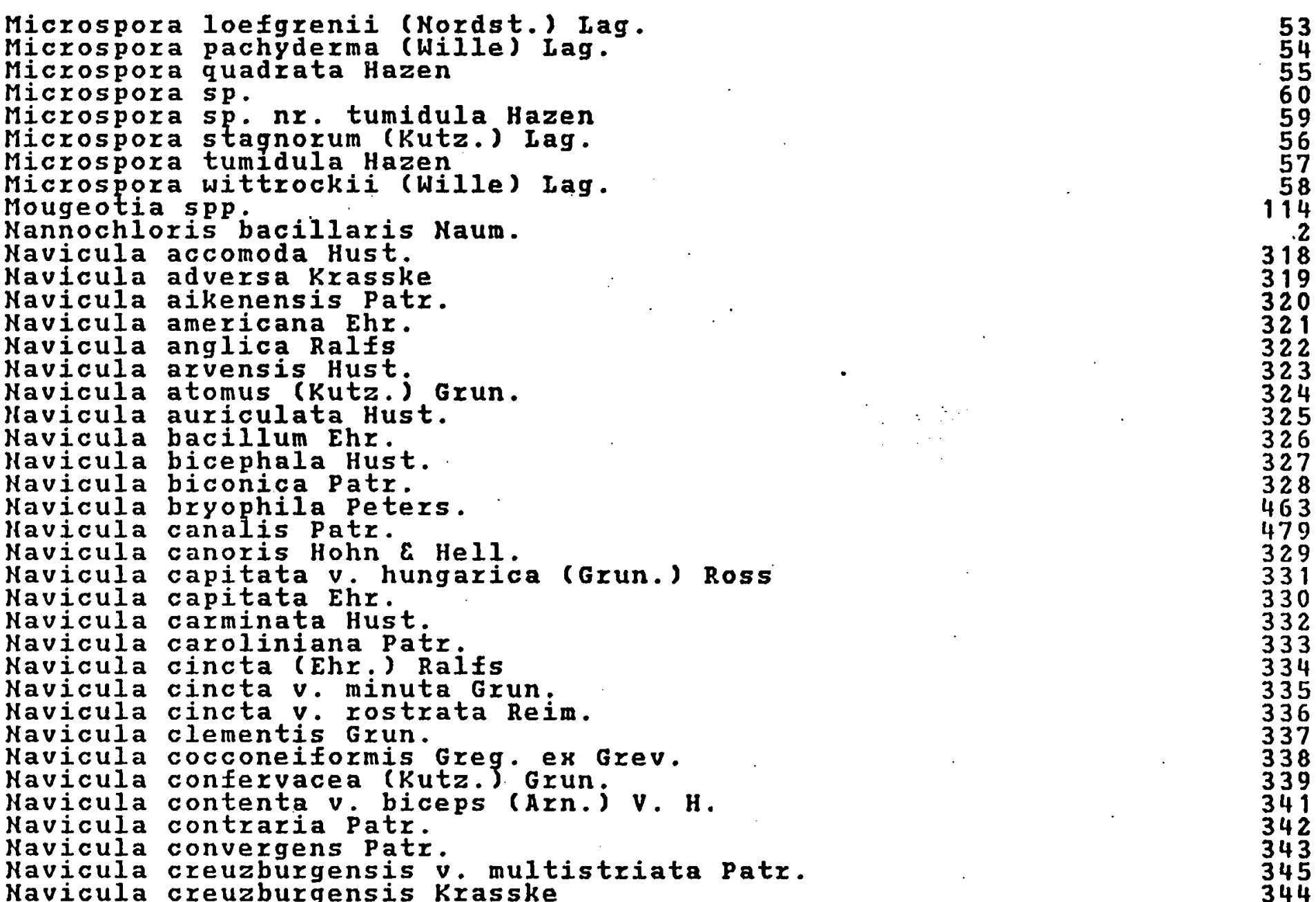


APPEYDIX A. SAVANMAH RIVER TAXONOMIC ACCESSION IIST

1. ALGAE

NOMENCLATURE

ACCESSIOK NO.

\section{GENUS \& SPECIES:}

Navicula cryptocephaia v. exilis (Kutz.) Grun.

347

Navicula cryptocephala v. veneta (Kutz.) Rabh.

348

Navicula cryptocephala Kutz.

Navicula cuspidata (Kutz.) Kutz.

Navicula decussis (Ehr.) Kutz.

Navicula digna Hust.

Navicula disputans patr.

Navicula duomedia Patr.

Navicula dystrophica Patr.

Navicula elginensis (Greg.) Ralts

Mavicula elginensis $v$. neglecta (Krasske) Patr.

Navicula exigua v. capitata Patr.

Navicula exigua Greg. ex Grun.

Navicula farta Hust.

Navicula festiva Krasske

Navicula gastrum (Ehr.) Kutz.

Mavicula genovefea Fusey

Navicula gibbosa Hust.

Mavicula gibbula Cl.

Mavicula gottlandica Grun

Navicula graciloides A. May.

Navicula gregaria Donk.

Mavicula grimmei Krasske

Navicula gysingensis Foged

Navicula halophila (Grun.) Cl

Navicula halophila f. subcapitata ostrup

Mavicula halophila f. tenuirostris Hust.

Navicula halophilioides Hust.

Navicula hambergi Hust.

Navicula hassiaca Krasske

Navicula heufleri v. leptocephala Grun.

Mavicula hustedtii Krasske

Navicula indifferens Hust.

Navicula ingenua Hust.

Navicula insociabilis Krasske

Navicula integra (N. Sin.) Ralfs

Mavicula krasskei Hust.

Navicula kuripanensis Hust.

346

349

350

464

351

474

352

354

356

355

472

357

358

462

359

458

465

461

461

475
360

361

362

364

363

476

365

366

368

369

370

459

371

372

Navicula lacustris Greg. 


\section{APFENDIX A. SAVANNAH RIVER TAXONOMIC ACCESSION LIST}

1. ALGAE

MOMENCLATURE

GENUS \& SPECIES:

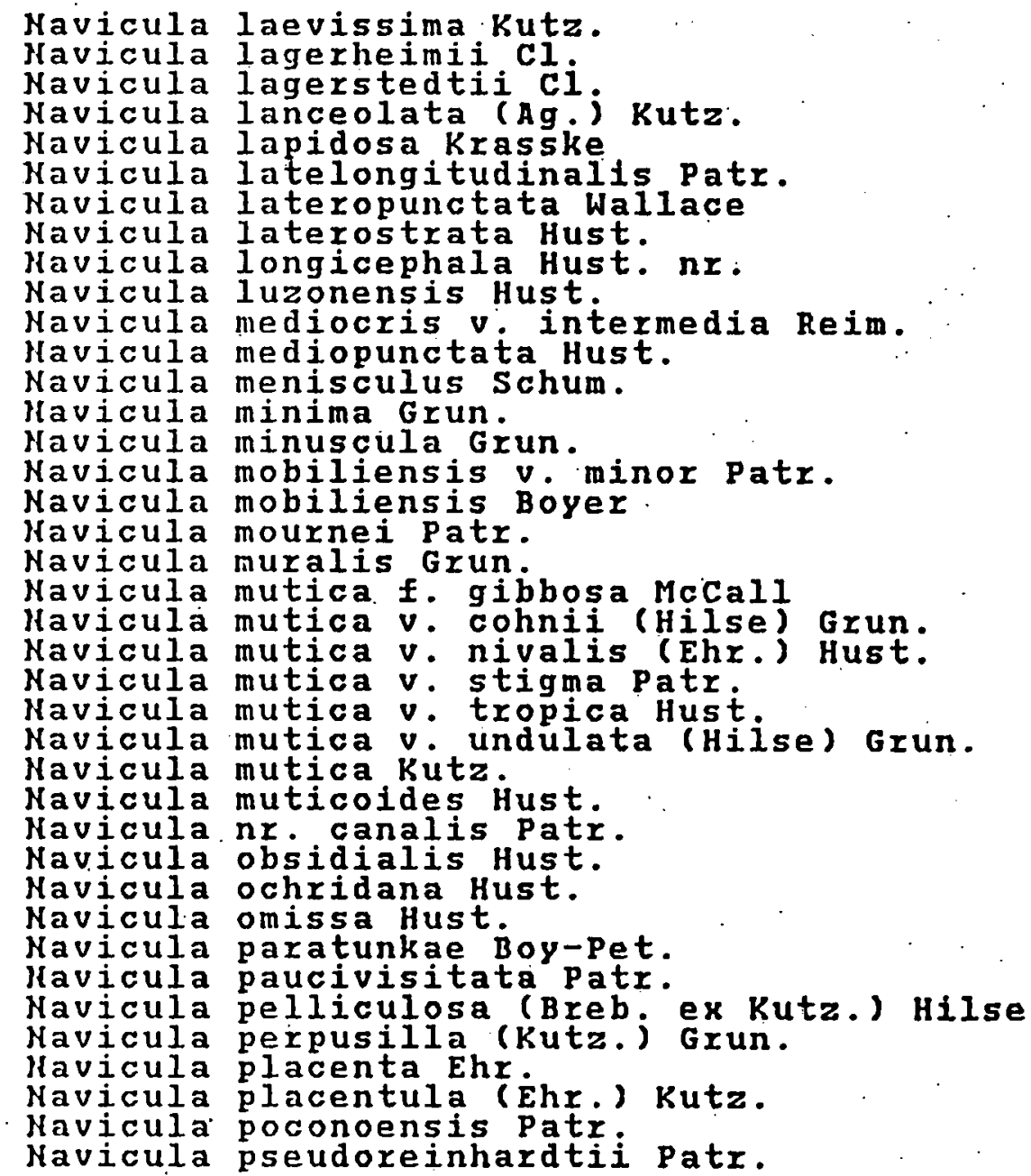

375

376

377

378

380

381

381

382
457

383

385

473

386

387

388

390

389

391

392

395

396

397

398

399

393

400

480

466

466

401

402

403

404

405

405

460

406

407

467

408 
1. ALGAE

NOMENCLATURE

ACCESSION NO.

\section{GENUS \& SPECIES:}

Mavicula pseudoscutiformis Hust.

Mavicula pupula v. capitata skv. E Mey.

Navicula pupula v. elliptica Hust.

Navicula pupula v. mutata (Krasske) Hust.

Navicula pupula v. rectangularis (Greg.) Grun.

Kavicula pupula Kutz.

Navicula pusilia W. Śm.

Mavicula pygmaea Kutz.

Navicula radiosa v. parva Wall.

Navicula radiosa Kutz.

Navicula rhynchocephala v. germainii (Wall.).patr.

Navicula rhynchocephala Kutz.

Navicula salinarum $v$. intermedia (Grun:) cl.

Navicula savannahiana Patr.

Navicula schonfeldii Hust.

Navicula schroeteri v. escambia Patr.

Navicula scutelloides W. Sm. ex Greg.

Kavicula scutiformis Grun. ex A.S.

Navicula secura Patr.

Navicula seminoides $\dot{c} 1$ \& Grun.

Navicula seminuloides Hust.

Navicula seminulum $v$. Intermedia Hust.

Mavicula seminulum Grun.

Navicula simula Patr.

Navicula sp.

Navicula subadnata Hust.

Navicula subfasciata patr.

Navicula subhalophila Hust.

Navicula subhamulata Grun.

Navicula submolesta Hust.

Navicula submuralis Hust.

Mavicula subtilissima C1.

Navicula symmetrica Patr.

Navicula taedia Wall.

Navicula tantula Hust.

Navicula tenelloides Hust.

Navicula tenera Hust.

Mavicula thienemannii Hust. 
1. ALGAE

MOMENCLATURE

ACCESSION NO.

GENUS \& SPECIES:

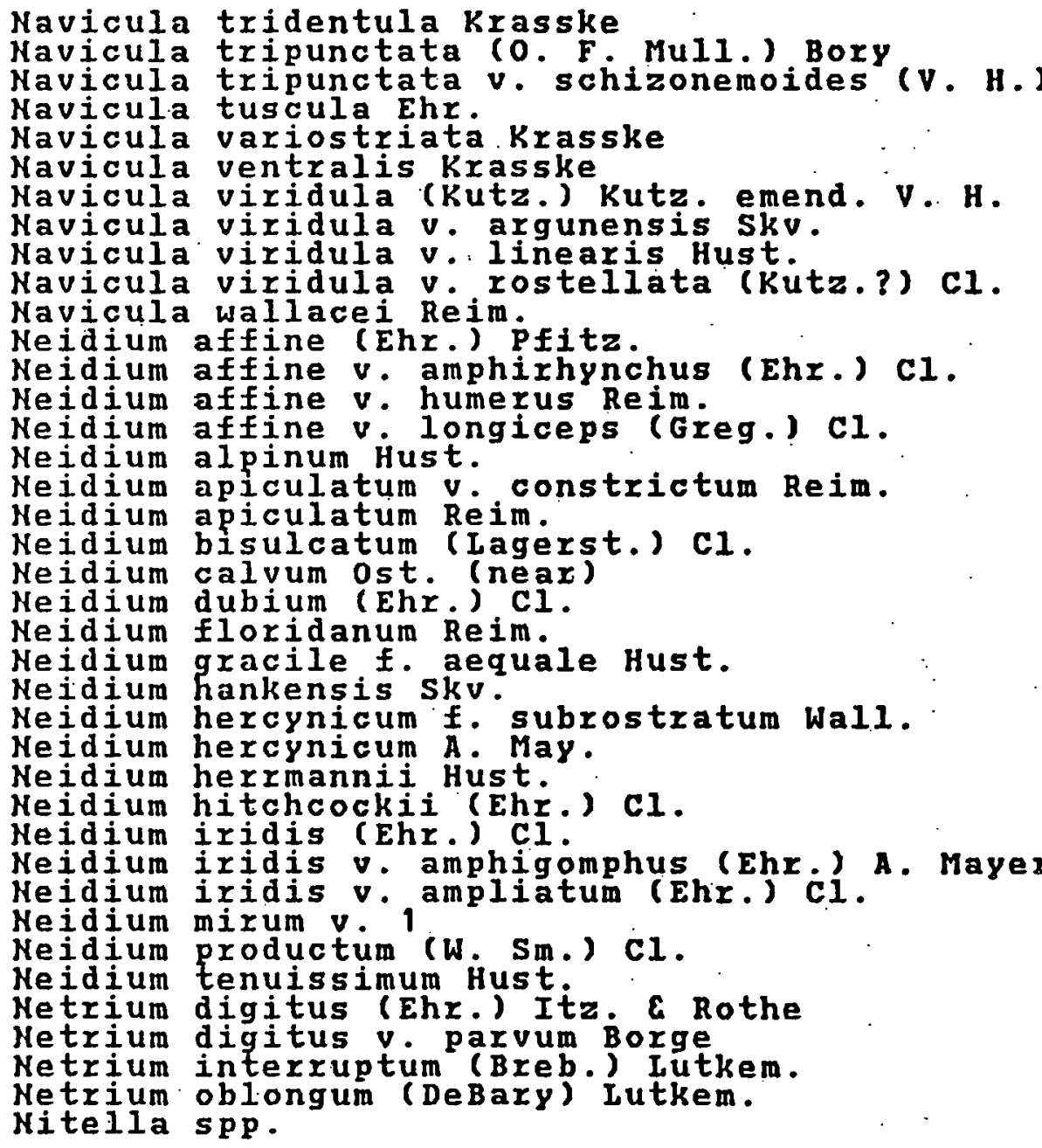




\section{APPENDIX A. SAVANKAH RIVER TAXONOMIC ACCESSION IIST}

1. ALGAE

NOMENCLATURE

ACCESSION NO.

GENUS \& SPECIES:

Nitzschia accomodata Hust.

Nitzschia acicularis $W$. Sm.

Kitzschia adamata Hust.

Nitzschia amphibia Grun.

Nitzschia apiculata (Greg.) Grun.

Nitzschia bacata Hust

Nitzschia biacrula Hohn \& Hell.

Nitzschia bulnheimiana v. capitata Reim.

Nitzschia capitellata (Hust.) Hust.

Nitzschia capitellata v. sibirica skv.

Nitzschia circumsuta (Bail.) Grun.

Nitzschia clausii Hantz.

Nitzschia communis $v$. hyalina Iund

Nitzschia commutata Grun.

Nitzschia confinis Hust.

Nitzschia constricta $v$. subconstricta Grun.

constricta v.

Nitzschia denticula Grun
Nitzschia diserta Hust.

Nitzschia dissipata (Kutz.) Grun.

Mitzschia dissipata v. media Hantz.

Nitzschia elliptica Hust.

Nitzschia filiformis (W. Sm.) Hust.

Nitzschia fonticola Grun.

Nitzschia frequens Hust.

Nitzschia frustulum $v$. perminuta Grun.

Nitzschia frustulum v. subsalina Hust.

Nitzschia frustuIum Kutz.

Nitzschia gracilis Hantz.

Nitzschia hungarica Grun.

Nitzschia intermedia Hantz. ex CI. \& Grun.

Nitzschia kutzingiana Hilse

Nitzschia lanceolata W.Sm.

Nitzschia limicolata w. Sm

Kitzschia linearis v. tenuis (W. Sm.) Grun.

Nitzschia linearis W. Sm.

Nitzschia lorenziana v. subtilis Grun.

Nitzschia mediastalsis Hohn \& Hell.

Nitzschia microcephala Grun

Nitaschia obtusav. scalpelifitormis Grun. 


\section{APPENDIX A. SAVAKNAH RIVER TAXONOMIC ACCESSION IIST}

1. ALGAE

MOMENCLATURE

ACCESSION NO.

GENUS \& SPECIES:

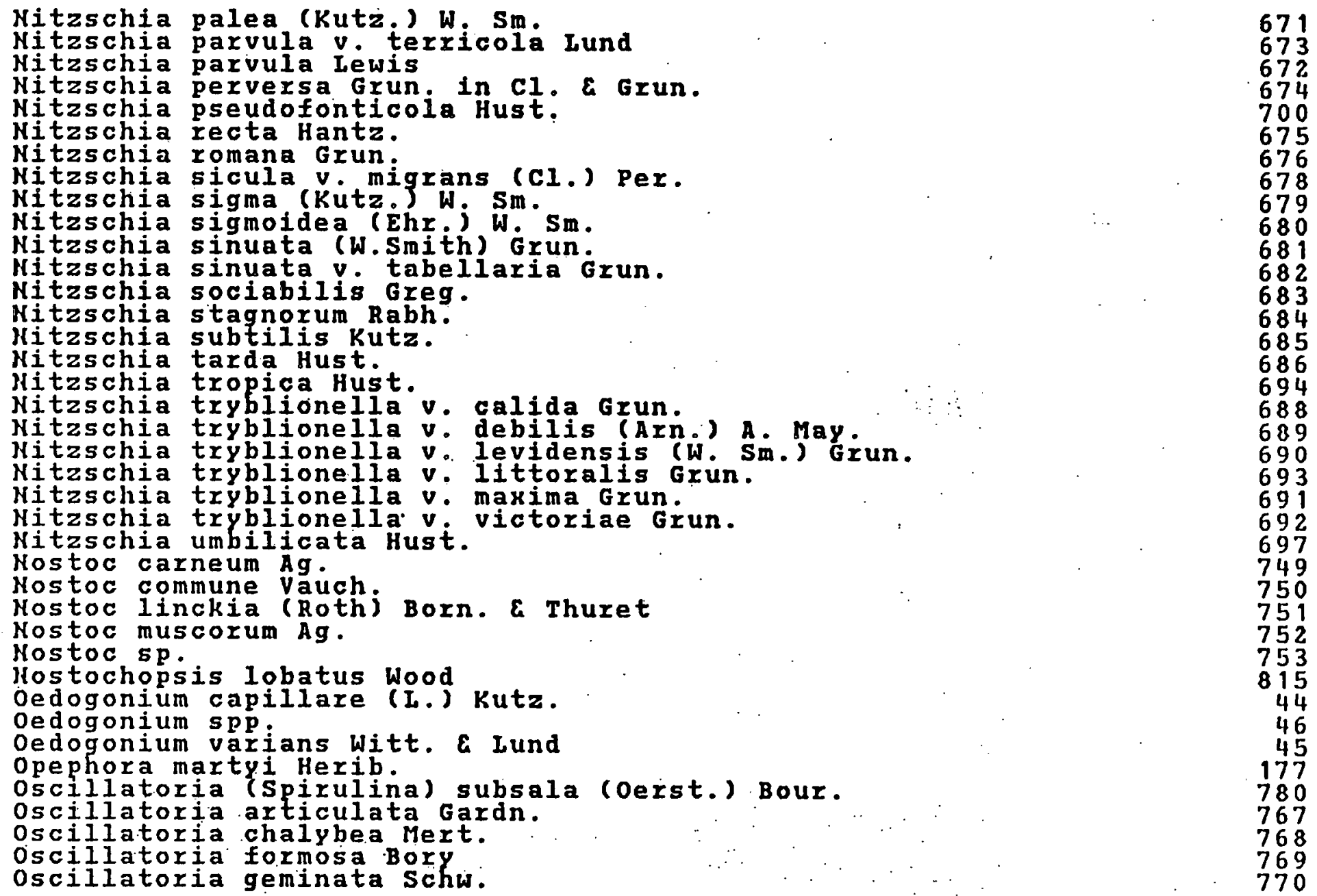


1. ALGAE

NOMENCLATURE

GENUS \& SPECIES:

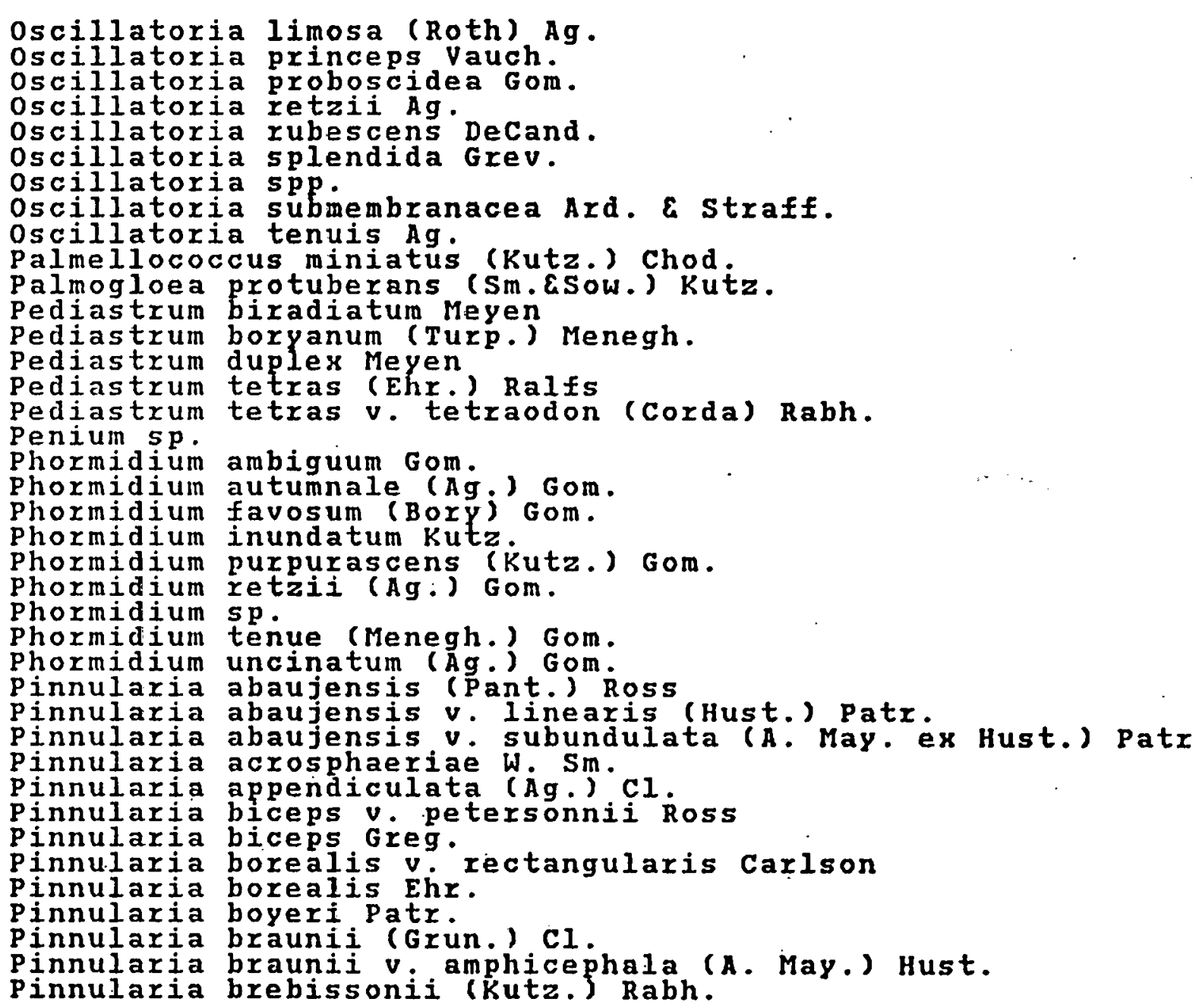

Pinnularia brebissonii (Kutz.) Rabh. 


\section{APPENDIX A. SAVANMAH RIVER TAXONOMIC ACCESSION LIST}

1. ALGAE

NOMENCLATURE

ACCESSION NO.

GENUS \& SPECIES :

Pińnularia brebissonii v. diminuta (Gxun.) c1.

Pinnularia brevicostata Cl.

Pinnularia burkii patr.

Pinnularia cardinalicuius cl.

Pinnularia dactylus Ehr.

Pinnularia divergens $v$. undulata (M. Per. \& Herib.) Hust.

Pinnularia divergens W. Sm.

Pinnularia flexuosa ci.

Pinnularia formica (Ehr.) Patr.

Pinnularia gibba v. parva (Ehr.) Grun.

Pinnularia globiceps Greg.

Pinnularia intermedia (Lag.) Cl.

Pinnularia maior (Kutz.) Rabh.

Pinnularia mesogongyla Ehr;

Pinnularia mesolepta (Ehr.; w. Sm.

Pinnularia mesolepta v. angusta ci.

Pinnularia microstauron (Ehr.) cl.

Pinnularia nodosa (Ehr.) W. Sm.

Pinnularia obscura Krasske

Pinnularia singularis (A.Schm.) Cl.

Pinnularia stomatophoroides v. ornata

Pinnularia stomatophoroides v. ornata $x$ triundulata (Font.)

Pinnularia subcapitata v. paucistriata (Grun.) c1.

Pinnularia subcapitata Greg.

Pinnularia substomatophora Hust.

Pinnularia termitina (Ehr.) Patr.

Pinnularia torta (Mann) Patr.

Pinnularia viridis (Nitz.) Ehr.

Pithophora oedogonia (Mont.) Wittr.

Plectonema nostocorum? Born.

plectonema spp.

Plectonema terebrans B. $F$

Plectonema tomasinianum (Kutz.) Born

Porphyrosiphon notarisii (Menegh,) Kutz.

Porphyrosiphon splendidus (Grev.) Dr;

Rhizoclonium hieroglyphicum (C.A.Ag.j Kutz.

Rhodochorton violaceum (Kutz) Dx.

Rhoicosphenia curvata (kutz;) Grun. ex Rabh.

Rhopalodia gibba (Ehx.) 0 . Mull. 


\section{APPENDIX A. SAVANNAH RIVER TAXONOMIC ACCESSION IIST}

1. ALGAE

\section{NOMENCLATURE}

ACCESSION NO.

GENUS \& SPECIES:

Rhopalodia gibberula (Ehr.) O. Mull.

Scenedesmus abundans (KIrch.) Chod.

Scenedesmus acuminatus ( $\mathrm{ag}$.) chod

Scenedesmus armatus (Chod.) G.M.Smith

Scenedesmus bijuga (Turp.) Lagerheim

Scenedesmus brasiliensis Bohlin

Scenedesmus dimorphus (Turp.) Kutz.

Scenedesmus incrassatulus v mononae G.M.Sm.

Scenedesmus opoliensis P. Richter

Scenedesmus quadricauda (Turp.) de Breb.

Scenedesmus quadricauda vi longispina (chod.) G.M.Smith

Schizochlamys gelatinosa A. Braun

Schizomeris leibleinii Kutz.

Schizothrix arenaria (Berk, Gom.

Schizothrix calcicola (Ag.) Gom.

Schizothris triesii (Ag.) Gom.

Schizothrix purpurascens (Kutz.) Gom.

Schizothrix rivularis (Wolle) Dr.

Schizothrix rubella Gom.

Schizothrix sp.

Scytonema hofmannii Ag.

Scytonema mirabile (Dilw.) Born

Selenastrum minutum (Naeg.) Collins

Sphaerocystis schroeteri Chod.

spirogyra spp

staurastrum aiternans Breb.

staurastrum dilatatum Ehr.

Staurastrum maxgaritaceum (Ehr.) Menegh.

Staurastrum orbiculare Ralfs

staurastrum pinnatum v. subpinnatum

Staurastrum suborbiculare $W$. $G$. S. West

stauroneis anceps t. gracilis Rabh.

Stauroneis anceps v. americana Rein.

stauroneis anceps Ehr.

stauroneis kriegeri patr.

stauroneis livingstonii Reim.

stauroneis obtusa lagerst.

Stauroneis phoenicenteron (Nitz.) Ehr.

stauroneis phoenicenteron f. gracilis (Ehr.) Hust. 


\section{APPENDIX A. SAVANNAH RIVER TAXONOMIC ACCESSION IIST}

1. ALGAE

MOMEMCLATURE

ACCESSION NO.

\section{GENUS \& SPECIES:}

Stauroneis smithil $v$. incisa pant.

stauroneis smithii Grun.

Stauroneis thermicola (Boy-pet.) Lund

stauroneis thermicola $v$. lanceolata Hust.

Stenopterobia intermedia (Lewis) V. H.

stephanodiscus hantzschii Grun.

Stephanodiscus invisitatus Hohn \& Hell.

stephanodiscus minutus pant.

Stichococcus bacillaris Nag

Stichosiphon zanzibaricus (Hieron.) Dr. E Daily

Stigeoclonium flagelliferum Kutz.

stigeoclonium lubricum (Dillw.) Kutz.

stigeoclonium spp.

stigonema mesentericum Geitl.

Surirella adumbratus Hohn \& Hell.

Surirella alicula Hohn \& Hell.

Surirella angustakutz.

Surirella biseriata Breb.

Surirella delicatissima lewis

Surirella guatemalensis Ehr.

Surirella linearis $\omega$. sm.

Surirelia minuta Breb.

Surirella moelleriana Grun.

Surirelia ovalis v. brightwellii (W. Sm.) Perag.

Surirella ovata v. pinnata ( $W$. Sm.) Hust.

Surirella ovata Kutz.

Surirelia robusta Ehr.

Surirella stalagma Hohn E Hell.

Surirella striatula Turp.

Surirella suecica Zell.

Surirella tenera v. nervosa A. Schm.

Surirella tenera Greg.

Symploca muralis Kutz.

Symploca muscorum (Ag.) Gom.

Synedra delicatissima v angustissima Grun

synedra fasciculata v. truncata (Grev.) Patr.

Synedra minuscula Grun.

Synedra parasitica (W. Sm.) Hust.

synedra parasitica v. subconstricta (Grun.) Hust. 
- MPPENDIX A. SAVANMAH RIVER TAXONOMIC ACCESSION IIST

1. ALGAE

MOMENCLATUPE

ACCESSIOH NO.

GENUS \& SPECIES :

Synedra pulchella v. lacerata Hust.

Synedra rumpens $v$. Eamiliaris (Kutz.) Hust. . 188

Synedra rumpens $v$. meneghiniana Grun.

Synedra rumpens v. scotica Grun.

Synedra socia Wall. 191

Synedra sp. 1 . . 197

Synedra tenera W. Sm.

Synedra ulna (Nitz.) Ehr.jutz) v. H

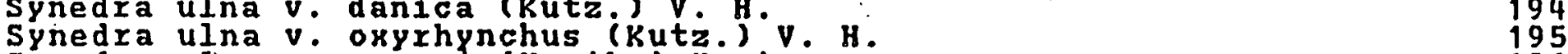

Synedra ulna $v$. ramesi (Herib.) Hust. 196

Tabellaria ferestrata (Iyngb.j Kutz.

Tabellaria flocculosa (Roth) Kutz.

Terpsinoe musica Ehr.

$\begin{array}{ll}\text { Tetraspora cylindrica (Wahl.) Ag. } & 29 \\ \text { Tetraspora gelatinosa (Vauch.) Desv. } & 30\end{array}$

$\begin{array}{ll}\text { Tetraspora gelatinosa (Vauch.) Desv. } & 31 \\ \text { Tetraspora lubrica (Roth) Ag. } & 31\end{array}$

Tetraspora spp.

Thalassiosira fluviatilis Hust. 141

$\begin{array}{lr}\text { Thorea wrangelii Ag } & 806\end{array}$

Tolypothrix tenuis Kutz.

Tuomeya fluviatilis Harv. A. Ag.) Derb. \& sol. 83

Ulothrix aequalis Kutz.

Ulothrix osciliarina kutz.

Ulothrix subtilissima Rabh.

Ulothris zonata (Weber \& Mohr) Kutz.

Uronema elongatum Hodg.

vaucheria spp.

Zygnema spp. 


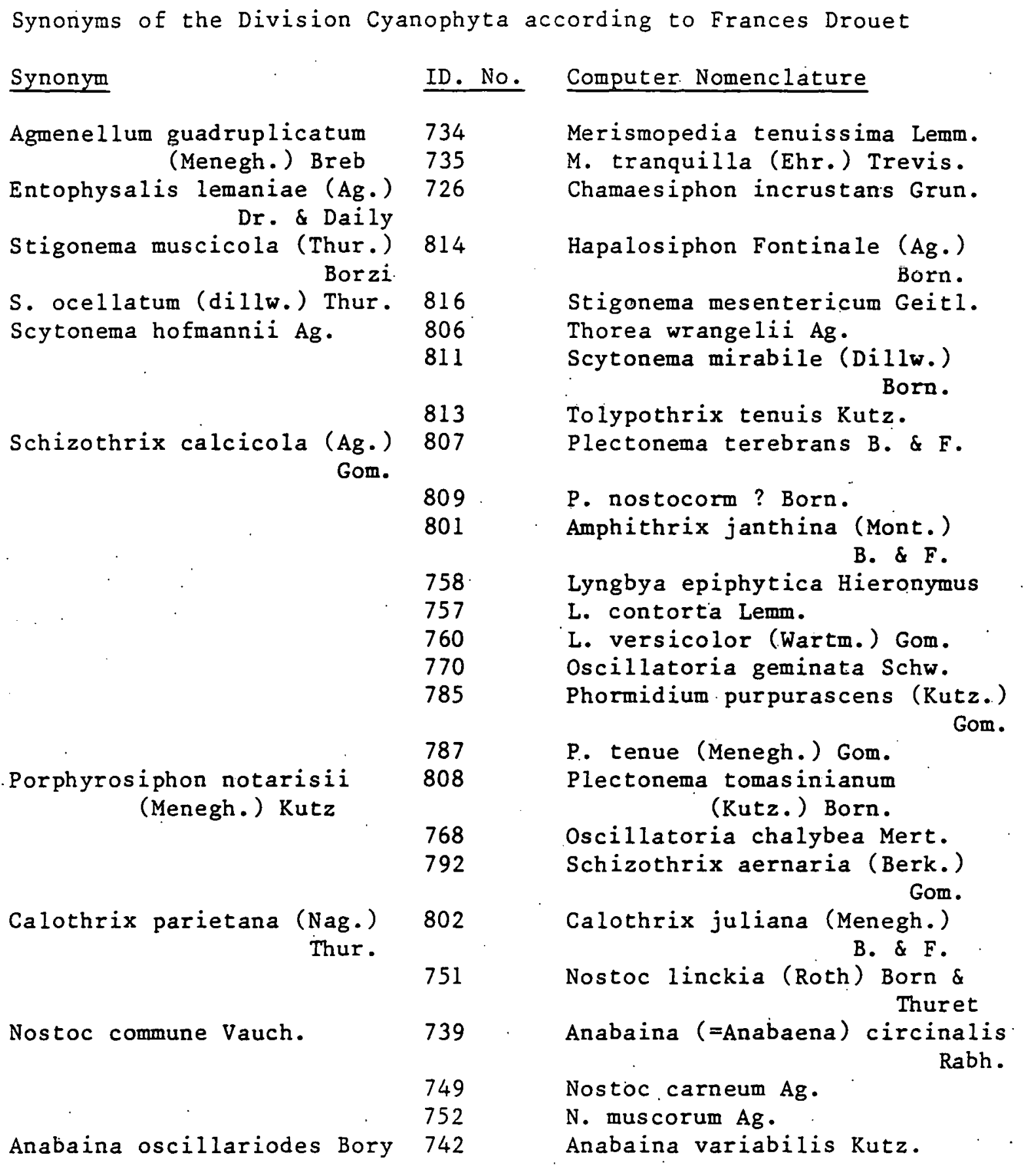


Synonym

Anabaina licheniformis Bory

744

746

747

Microcoleus vaginatus

(Vauch.) Gom

M. Iyngbyaceus Ketz.

Oscillatoria retzii Ag

S. arenaria (Berk.) Gom.

S. rubella Gom.

765

784

799

Porphyrosiphon animals (Ag.) 769 Dr.

Oscillatoria princeps Vauch. 773

Porphyrosiphon splendidus (Grev.) Dr.

776

Schizothrix friesii ( $\mathrm{Ag} \cdot$ )

796
ID. No. Computer Nomenclature

Cylindrospermum catenatum Ralfs

C. licheniforme (Bory) Kutz.

C. majus Kutz.

C. musicola Kutz.

Lyngbya aerugineo-caerulea (Kutz.) Gom.

Phormidium ambiguum Gom.

P. autumnale (Ag.) Gom.

P. favosum (Bory) Gom.

P. uncinatum (Ag.) Gom.

Lyngbya aestuarii (Mert.)

Liebmann

Oscillatoria articulatata

0. 1imosa (Roth) Ag.

0 . rubescens DeCand.

o. tenuis $\mathrm{Ag}$.

Lyngbya bicolor Wood

Phormidium retzii (Ag.) Gom.

Symploca muscorum (Ag.) Gom.

Lyngbya putealis Mont. ex Gom.

Microcoleus chthonoplastes

(Mert.) Zanard

M. paludosus (Kutz.) Gom.

Phormidium inundatum Kutz.

Symploca muralis Kutz..

Oscillatoria formosa Bory

0. proboscidea Gom.

o. splendida Grev.

Schizothrix rivularis (Wolle)

Dr. 
APPENDIX A. SAVANNAH RIVER TAXONOMIC ACCESSION LIST

2. FISHES

MOMENCLATURE

ACCESSION 10.

PHYLUM :

Chordata

4313

CLASS :

Osteichthyes

4314

ORDER :

Amiteormes

Anguilitiformes

A theriniformes

clupeiformes

Cypriniformes

Perciformes

Percopsciformes

pleuronectiformes

Salmoniformes

Semionotiformes

siluriformes

FAMILY :

Amblyopsidae

Amiidae

Anguilidae

A phredoderidae

A the rinidae

Belonidae

Catostoinidae

Centrarchidae

Clupeidae

Cyprinidae

Cyprinodontidae

Echelidae

Engraulidae

Esocidae

Ictaluridae

Lepisosteidae

Mugilidae 
APPENDIX A. /SAYANNAH RIVER TAXONOMIC ACCESSION IIST

2. FISHES

NOMENCLATURE

ACCESSION NO.

FAMILY:

$$
\begin{aligned}
& \text { Paralichthidae } \\
& \text { Percichthyidae } \\
& \text { Percidae } \\
& \text { Poeciliidae } \\
& \text { Sciaenidae } \\
& \text { Soleidae } \\
& \text { Umbridae }
\end{aligned}
$$

GENUS \& SPECIES :

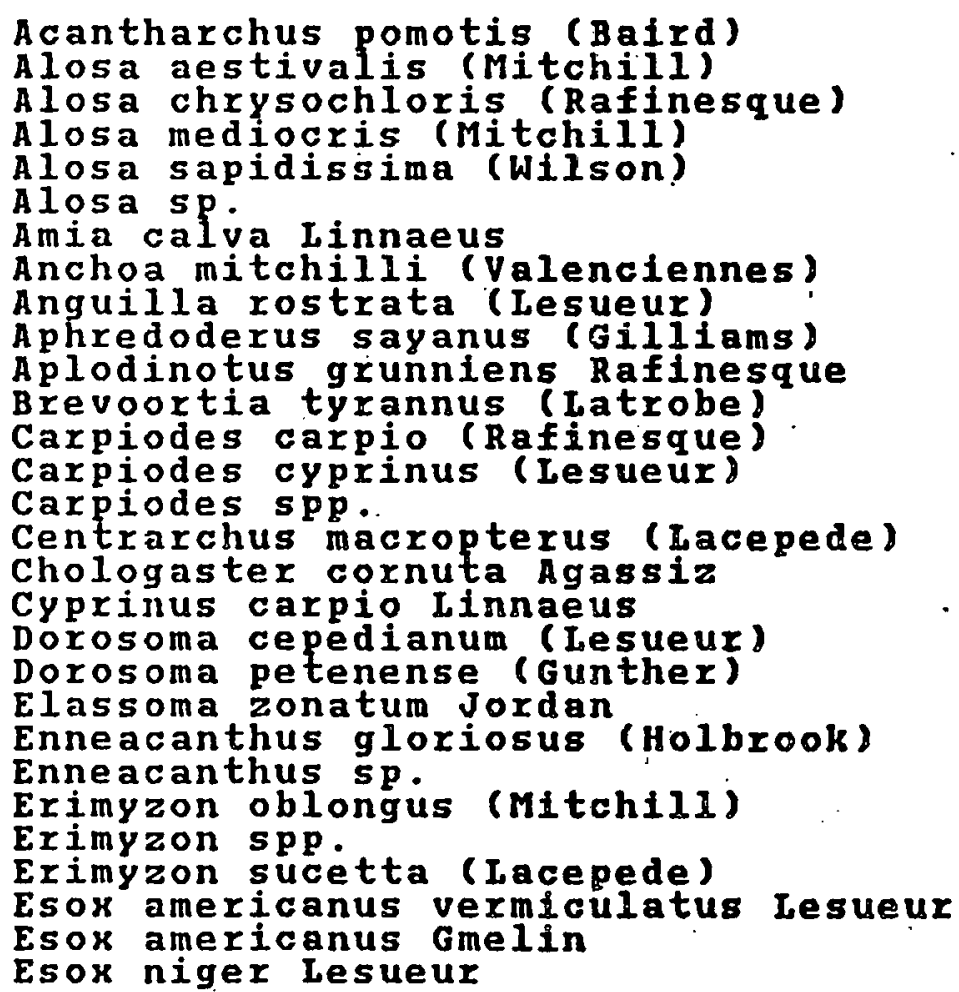

Esox niger Lesueur 
2. FISHES

NOMENCLATURE

ACCESSION NO.

GENUS \& SPECIES :

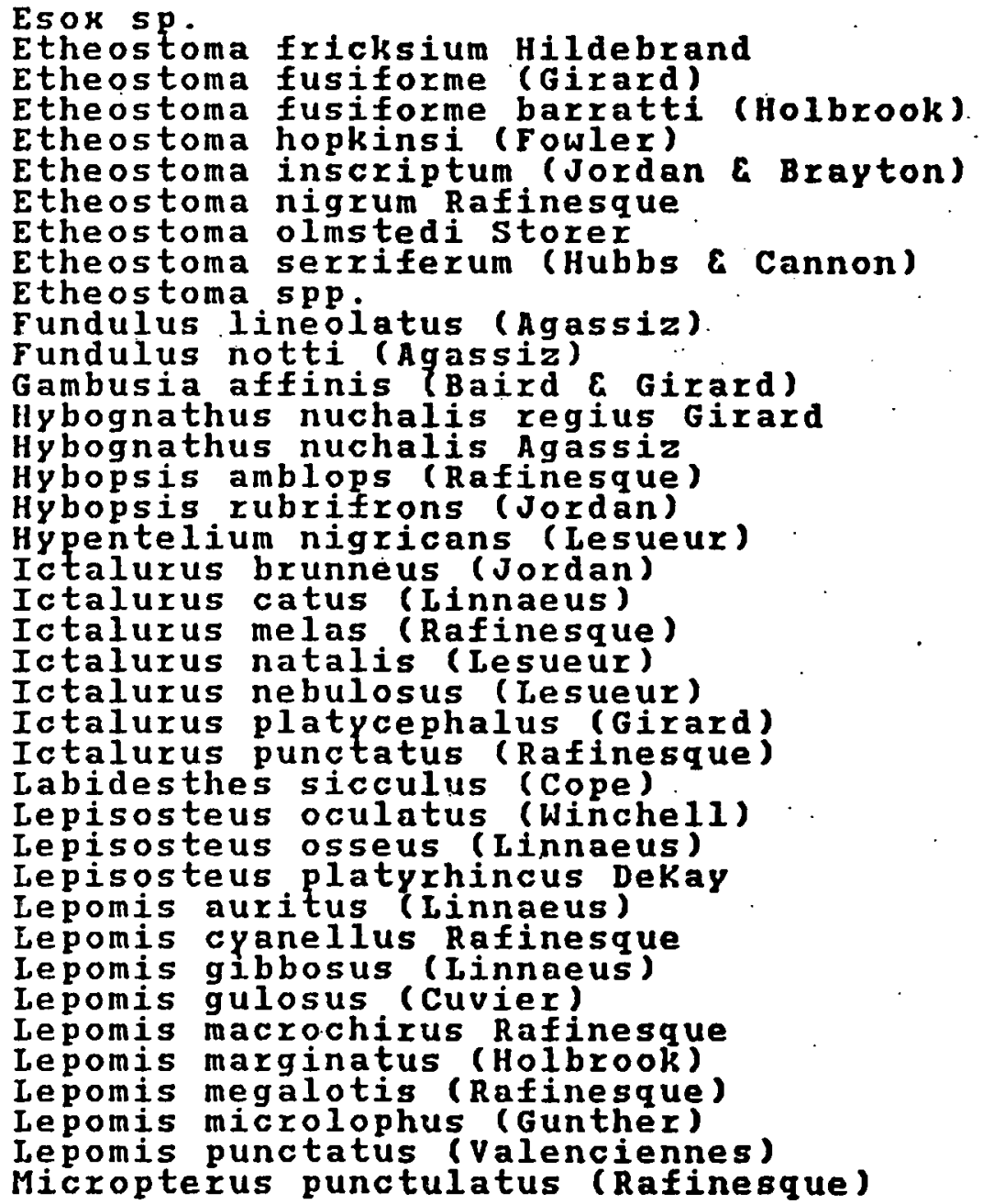


APPEMDIX A. SAVANMAH RIVER TAXONOMIC ACCESSION IIST

2. FISHES

NOMENCLATURE

ACCESSION NO.

\section{GENUS \& SPECIES:}

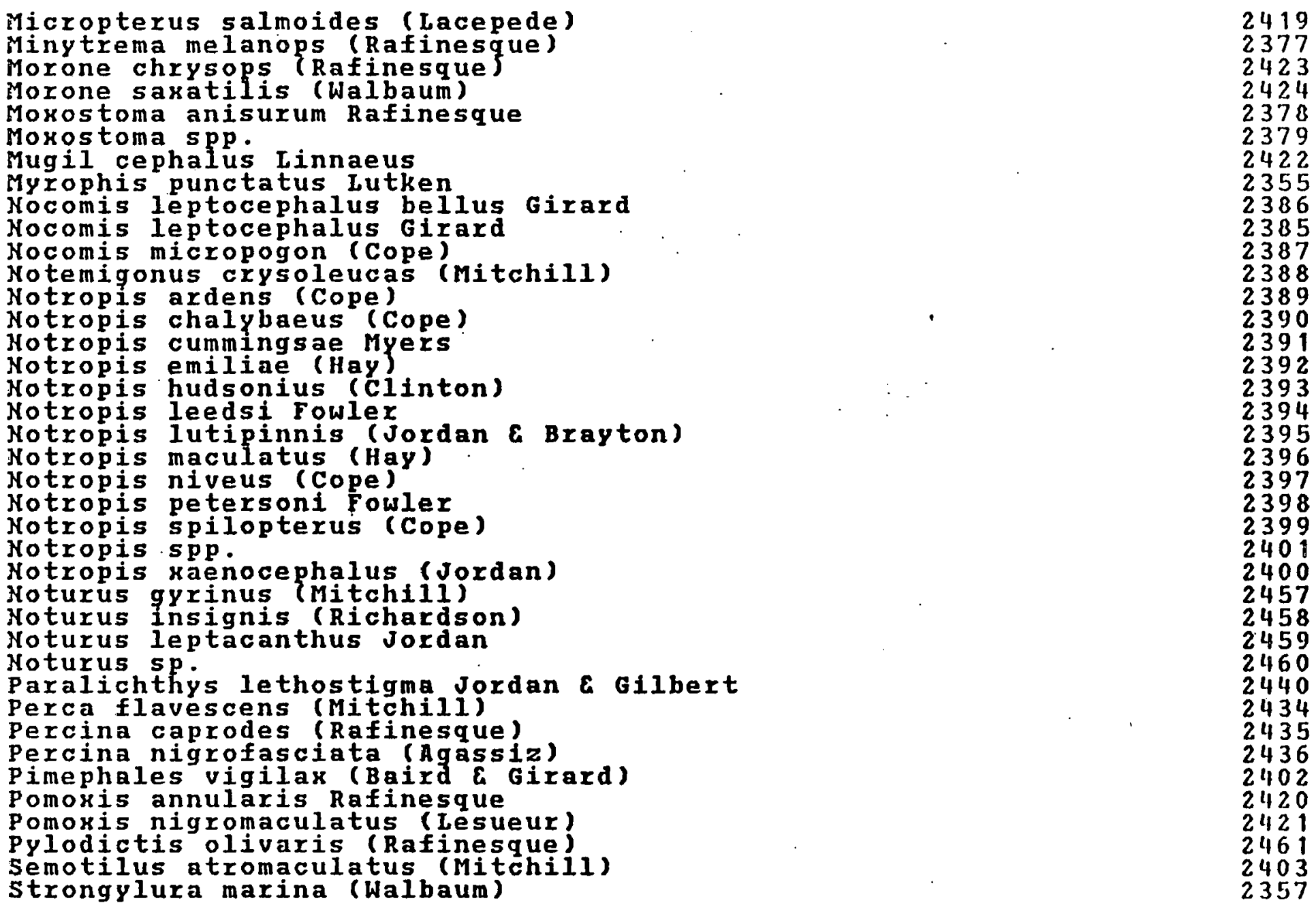


APPENDIX A. SAVANMAH RIVER TAXONOMIC ACCESSION LIST

2. FISAES

NOMENCLATURE

ACCESSION NO.

GENUS \& SPECIES:

Trinectes maculatus (Block \& schneider) Umbra pygmaea (Dekay)

2441

2446 
APPENDIX A. SAYANNAH RIVER TAXONOMIC ACCESSION IIST

3. MACRO-INVERTEBRATES

MOMENCLATURE

ACCESSIOK NO.

PHYIUM :

Annelida
Arthropoda
Aschelminthes
Bryozoa
Molius a
Memertea
platyhelminthes
Porifera
Tardigrada

CLASS :

Arachnoidea

Bivalvia

Crustacea

Demospongae

Ectoprocta

Enopla

Eutardigrada

Gastropoda

Gastrotricha

Hirudinoidia

Insecta

Mematoda

Nematomorpha

oligochaeta

Rotifera

Turbeliaria

ORDER :

Alloeocoela

Amphipoda

Arhynchobdellidae

Basommatophora

Bdelloidea

Branchiura

Catenulida

cladocera 
APPENDIX A. SAVANKAH RIVER TAXONOMIC ACCESSION IIST

3. MACRO-INVERTEBRATES

NOMENCLATURE

ACCESSION NO.

ORDER :

Coleoptera

Decapoda

Diptera

Ephemeroptera

Eucopepoda

Gordioidea

Gymolaemata

Haplosclexina

Haplotarida

Hemiptera

Hoplonemertea

Hydrocarina

Isopoda

Lepidoptera

Lumbriculida

Macrobiotoidea

Megaloptera

Mermithoidea

Mesogastropoda

Monogononta

Neorhabdocoela

Neuroptera

odonata

Phylactolaemata

plecoptera

Rhynchobdellae

Trichoptera

Tricladida

Unionoida

Veneroida

4100

3919

4208

3994

3896

3711

3721

3617

3767

4059

3646

3929

3906

4205

3761

3716

4094

3707

3811

3657

3634

4091

3960

3726

4037

3741

4169

3625

3851

3867

\section{FAMILY :}

Ae olosomatidae

3806

Aeshnidae

3977

3838

3902

3930

Argulidae

Arrenuridae

3908 
APPENDIX A. SAVAKMAH RIVER TAXONOMIC ACCESSION IIST

3. MACRO-INVERTEBRATES

MOMENCLATURE

ACCESSION NO.

FAMILY:

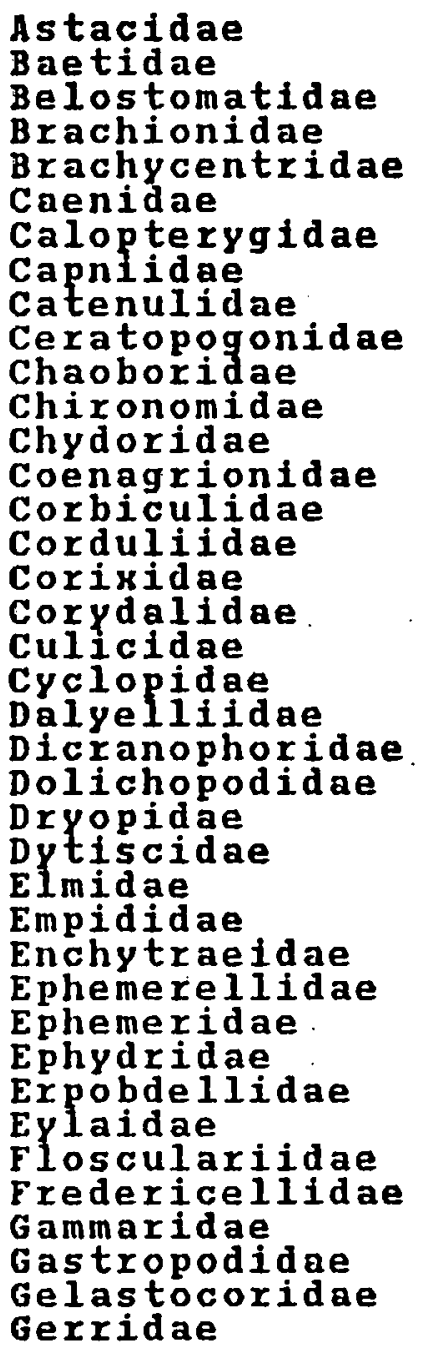

4222

422.9

3886

3965

3870

3984

4087

4097

4219

3898

3635

3667

4304

4159

4108

4162

4302

3770

4019

4032

4311

3755

3933

3697

3727

3914

3674

4077

Gerridae

4062 
APPEHDIX A. SAVANKAH RIVER TAXONOMIC ACCESSION IIST

3. MACRO-INVERTEBRATES

MOMENCLATURE

ACCESSION NO.

\section{FAMILY:}

Glossiphonitidae

Glossoscolecidae

3744

Gomphidae

3792

Gyrinidae

Haliplidae

Heptageniidae

Hydrobiidae

Hydrodromidae

Hydrome tridae

Hydrophilidae

Hydropsychidae

Hydroptilidae

Hy robatidae

Krend owskidae

lebertildae

recanidae

Iepidos tomatidae

Leptoceridae

Leptophlebiidae

libeliulidae

limnephilidae

Iimnesidae

Iindidae

lophopodidae

Lumbricidae

Iumbriculidae

Iymnaeidae

Macrobiotidae

Macromiidae

Megascolecidae

Mermithidae

Mesoveliidae

Naididae

Naucoridae

Nemouridae

Neoephemeridae

Mepidae

Notommatidae 
APPENDIX A. SAVANNAH RIVER TAXONOMIC RCCESSIOK IIST

\title{
3. MACRO-INVERTEBRATES
}

NOMENCLATURE

ACCESSIOY NO.

\section{FAMILY :}

\author{
Notonectidae \\ oligoneurildae \\ Omophronidae \\ Oridae \\ Palaemontdae \\ Paludicelildae \\ Perlidae \\ Perlodidae \\ Philopotamidae \\ Physidae \\ Pionidae \\ piscicolidae \\ Plagios tomidae \\ Planariidae \\ Planorbidae \\ Pleuroceridae \\ Plumatelidae \\ Polycentropodidae \\ pteronarcidae \\ Pyralidae \\ Rhagionidae \\ Sciomyzidae \\ Sialidae \\ Sididae \\ Simuliidae \\ Siphlonuridae \\ Sisyridae \\ Sphaeriidae \\ spongillidae \\ stenos tomidae \\ stratiomyidae \\ Synchaetidae \\ Tabanidae \\ Taeniopterygidae \\ Talitridae \\ Testudinellidae \\ Tetrasteminatidae \\ Tipulidae \\ Trichocercidae
}

4085
4007
4102
3948
3920
3722
4052
4049
4171
3847
3950
3750
3639
3626
3842
3828
3732
4173
4047
4206
4299
4308
4095
3884
4289
3995
4092
3872
3618
3632
4294
3677
4296
4042
3912
3695
3647
4211
3671


APPENDIX A. SAVANMAH RIVER TAXONOMIC ACCESSTON LIST

\section{3. 'MACRO-INVERTEBRATES}

MOMENCLATURE

ACCESSION NO.

\section{FAMIIY :}

$$
\begin{aligned}
& \text { Tricorythidae } \\
& \text { Tubificidae } \\
& \text { Unionicolidae } \\
& \text { Unionidae } \\
& \text { Valvatidae } \\
& \text { Veliidae } \\
& \text { Victorellidae } \\
& \text { Viviparidae }
\end{aligned}
$$

GENUS \& SPECIES:

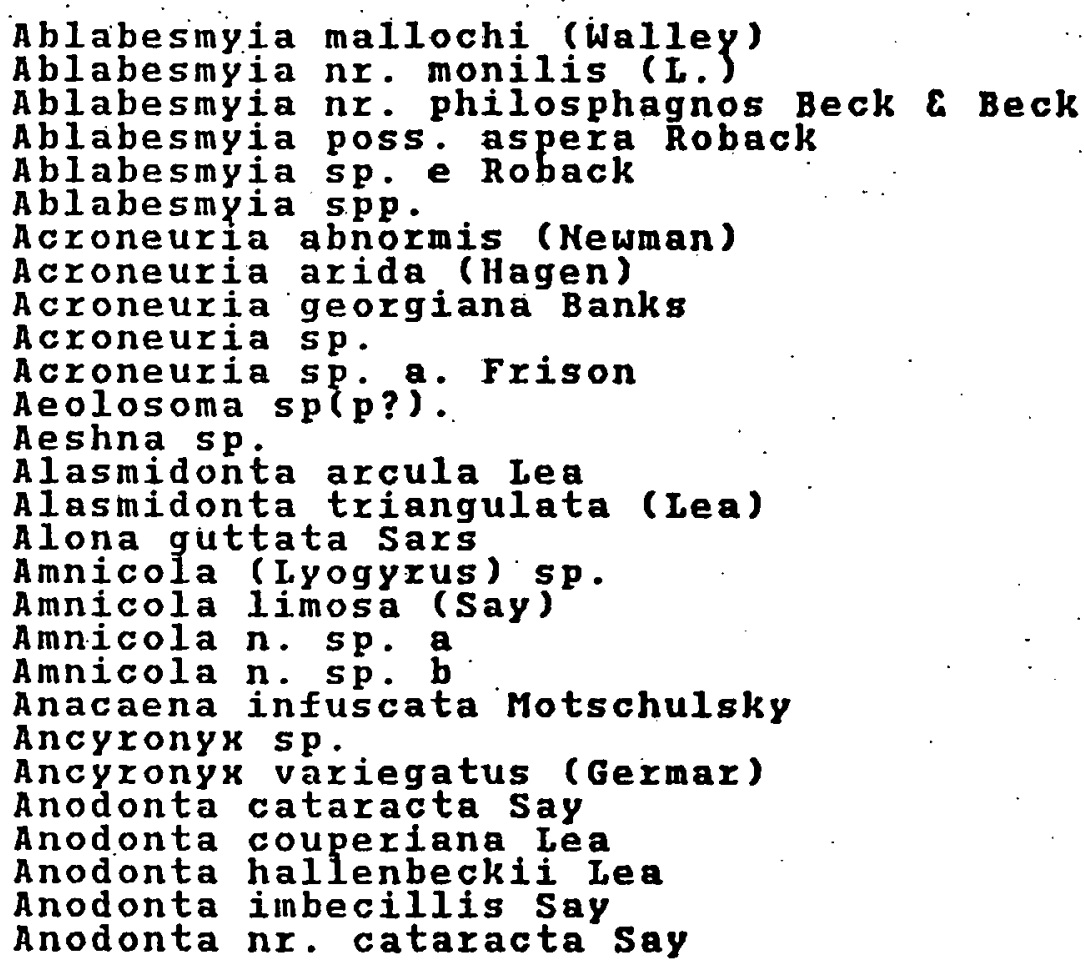


APPENDIX A. SAVAHNAH RIVER TAXONOMIC ACCESSION IIST

3. HACRO-INVERTEBRATES

MOMENCLATURE

ACCESSION HO.

GENUS \& SPECIES:

Anopheles $\mathbf{s p}$.

Arcteonais lomondi (Martin)

Argia apicalis (Say)

Argia moesta (Hagen)

Argia sedula (Hagen)

Argia sp

Argia tibialis (Rambur)

Argia translata Hagen

Argia violacea (Hagen)

Argulus sp.

Arrenurus sp(p?).

Aselius attenuatus Richardson

Asellus coinmunis (Say)

Aselius militaris Hay

Aspelta aper (Harring)

Atanytarsus sp.

Atherix sp.

Atractides $\mathbf{s p}$.

Atrichopogon sp.

Aulophorus furcatus (Muller)

Baetis spp.

Basiaeschna janata (Say)

Batracobdella phalera (Graf)

Belostoma flumineum Say

Belostoma lutarium (stal)

Belostoma sp.

Berosus aculeatus Leconte

Berosus exiguus say

Berosus fraternus Leconte

Berosus infuscatus leconte

Berosus pantherinus Leconte

Berosus peregrinus (Herbst)

Berosus pugnax? Ieconte

Berosus sp.

Berosus striatus (say)

Bezzia or Probezzia sp.

Bidessus obesus? Shp.

Boyeria vinosa (Say)

Brachionus calyciflorus pallas 
APPEMDIX A. SAVANKAH RIVER TAXONOMIC ACCESSION IIST

\section{MACRO-INVERTEBRATES}

NOMENCLATURE

GENUS \& SPECIES:

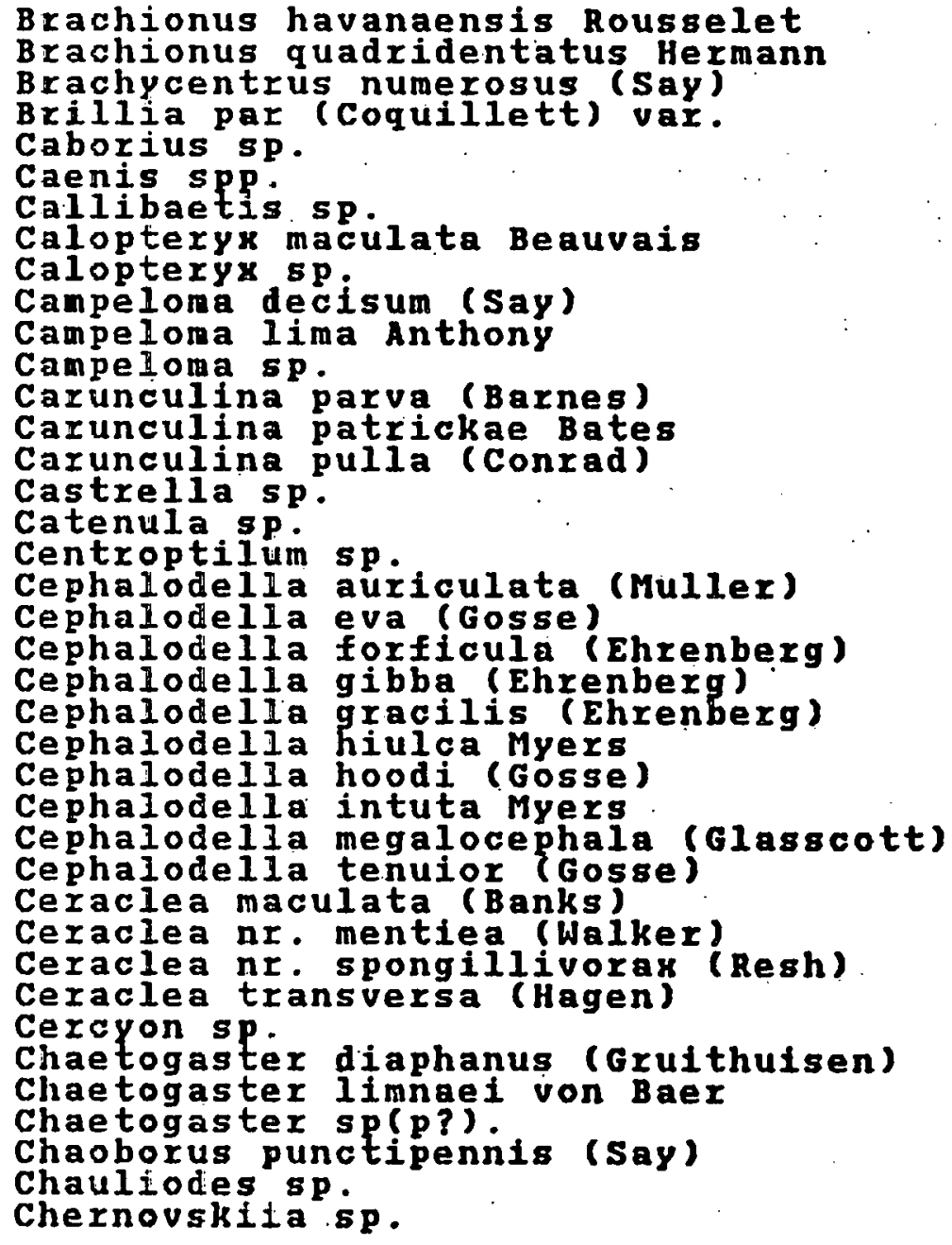


APPENDIX A. SAVAKKAH RIVER TAXONOMIC ACCESSION IIST

3. MACRO-INVERTEBRATES

NOMENCLATURE

ACCESSION NO.

GEYUS \& SPECIES:

Cheumatopsyche spp.

Chimarra nr. feria Ross

2209

Chimarra prob. aterrima Hagen

Chimarra prob. socia Hagen

Chimarra sp.

Chironomus decorus Johannsen

Chromogaster ovalis (Bergendal)

Chrysops sp.

Cladopelma naig? (Townes)

Climacea areolaris Hagen

Clinotanypus pinguis (Loew)

cloeon sp.

Coelambus (Hygrotus) spp.

Coelambus dissimilis Gemminger \& Harold

Coelambus inaequalis (Fabricius)

Coelambus sp p.

Coelotanypus scapularis (Loew)

Coelotanypus tricolor (Loew)

Colurella anodonta Carlin

Colurelia colura (Ehrenberg)

Colurella obtusa (Gosse)

Colurella sinistra Carlin

Colurella uncinata (Muller)

Copelatus glyphicus (say)

Copelatus sp.

Coptotomus interrogatus (rabricius)

Coptotomus spp

Corbicula fluminea (Muller)

Corbicula manilensis (Philippi)

Cordites sp.

Corydalus cornutus (Linnaeus)

Corynoneura (Corynoneura) nr. celeripes winnertz

2202

2201

2203

2204

2299

1623

2.346

2300

2050

2259

1962

2080

2076

2077

2078

2079

2257

2258

1633

1635

1636

1637

1638

2096

2097

2098

2099

1841

1842

2274

2053

Corynoneura (Corynoneura) nr.

Corynoneura (Thienemannielia)

nx. Hena Roback

2275

2276

2277

2278

1875

crenitis subcupreus (Say)

cricotopus bicinctus (Meigen) 


\section{APPENDIX A. SAVANKAH RIVER TAXONOMIC ACCESSION IIST}

3. MACRO-INVERTEBRATES

NOMENCLATURE

ACCESSION NO.

GENUS E SPECIES :

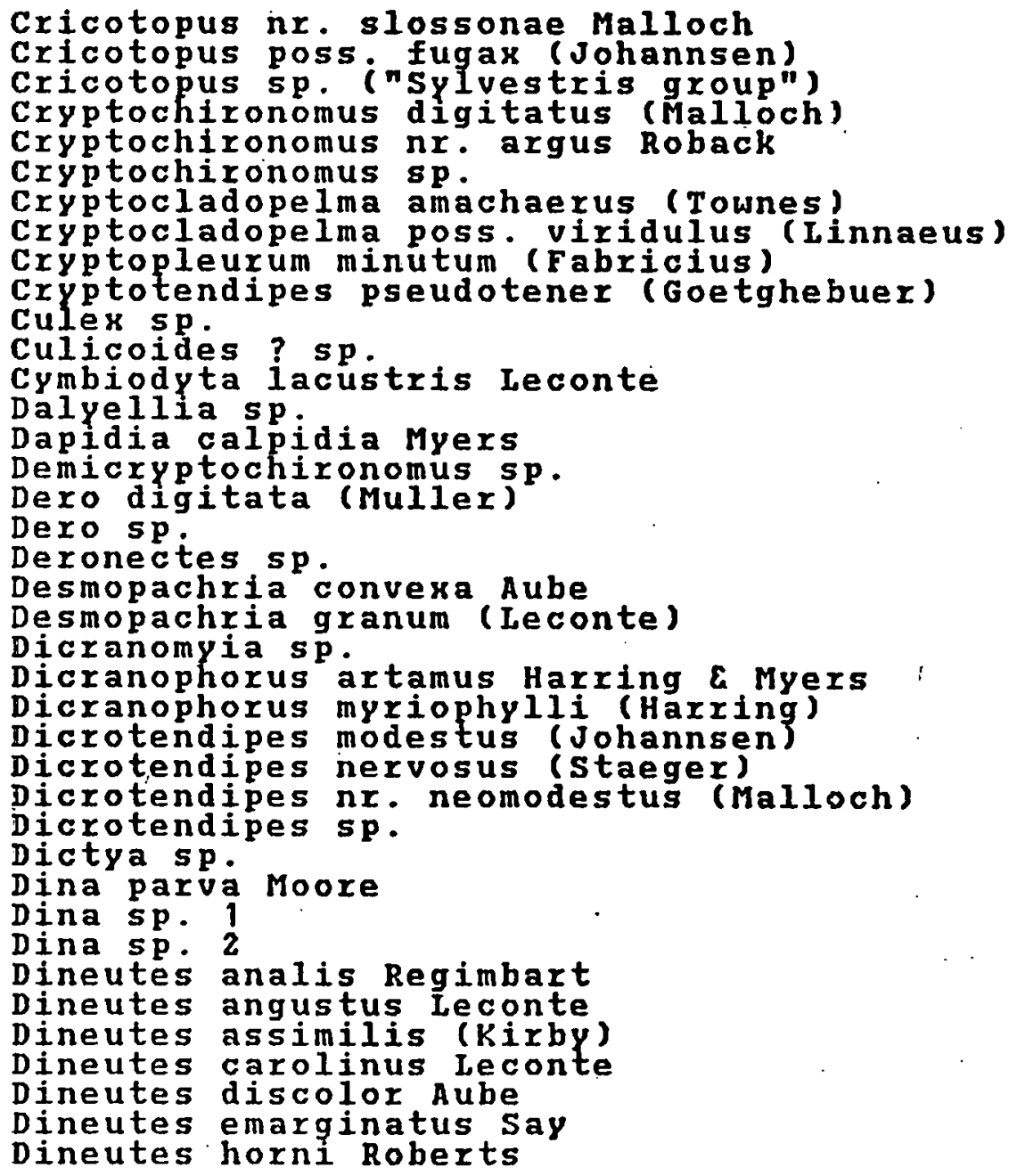

2281

2280

2282

2301

2302

2303

2304

2305

2168

2306

251

2255

2255

142

1589

1639

2307

1732

1733

2081

2082

2083

2244

1613

1614

2308

2309

2310

2311

2351

1704

1705

1706

2105

2106

2107

2108

2109

2110

2111 
3. MACRO-INVERTEBRATES

NOMENCLATURE

ACCESSION NO.

GENUS \& SPECIES :

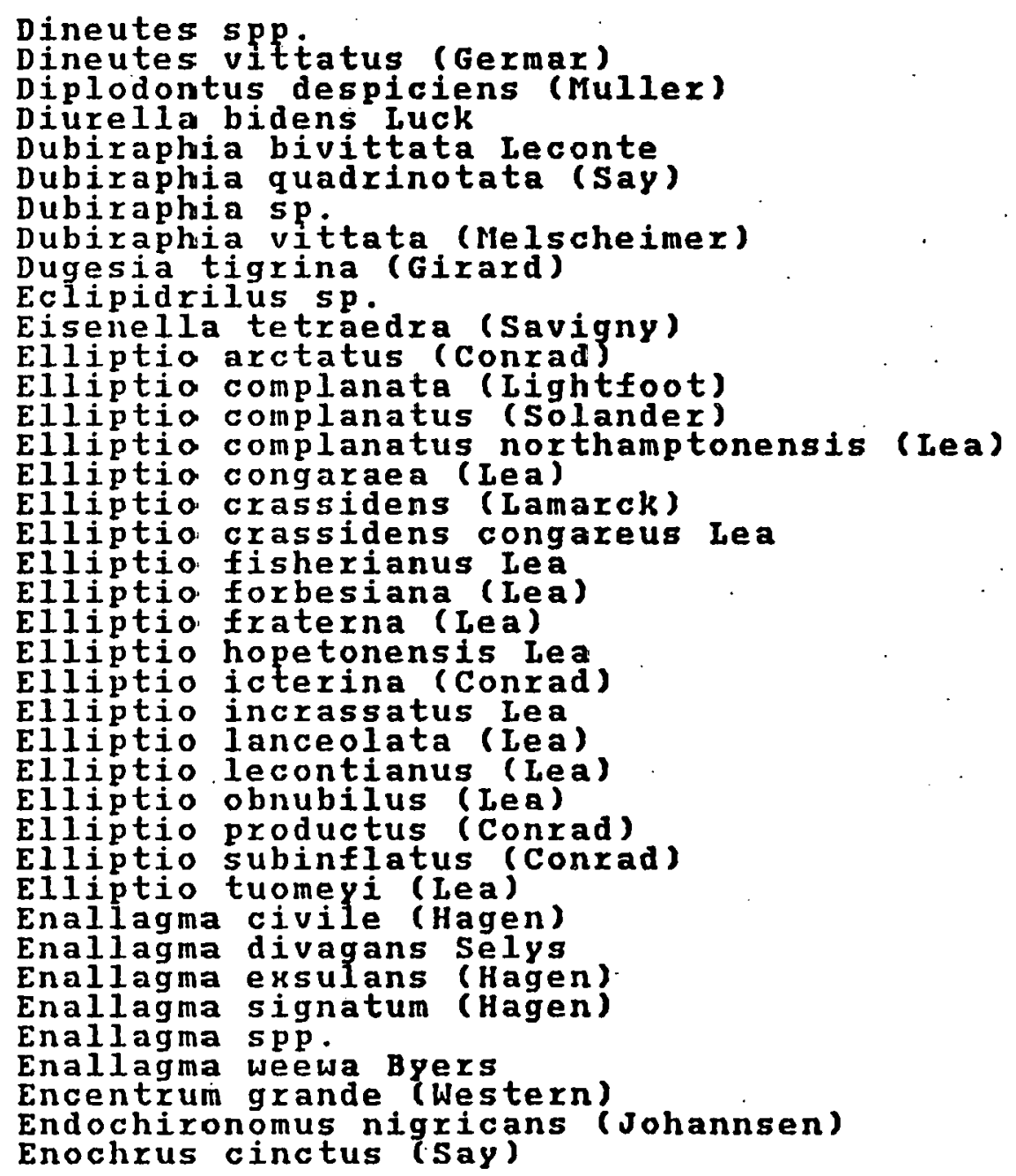




\section{APPEMDIX A. SAVANMAH RIVER TAXONOMIC ACCESSION IIST.}

3: MACRO-IMVERTEBRATES

MOMENCLATURE

ACCESSION NO.

GENUS \& SPECIES:

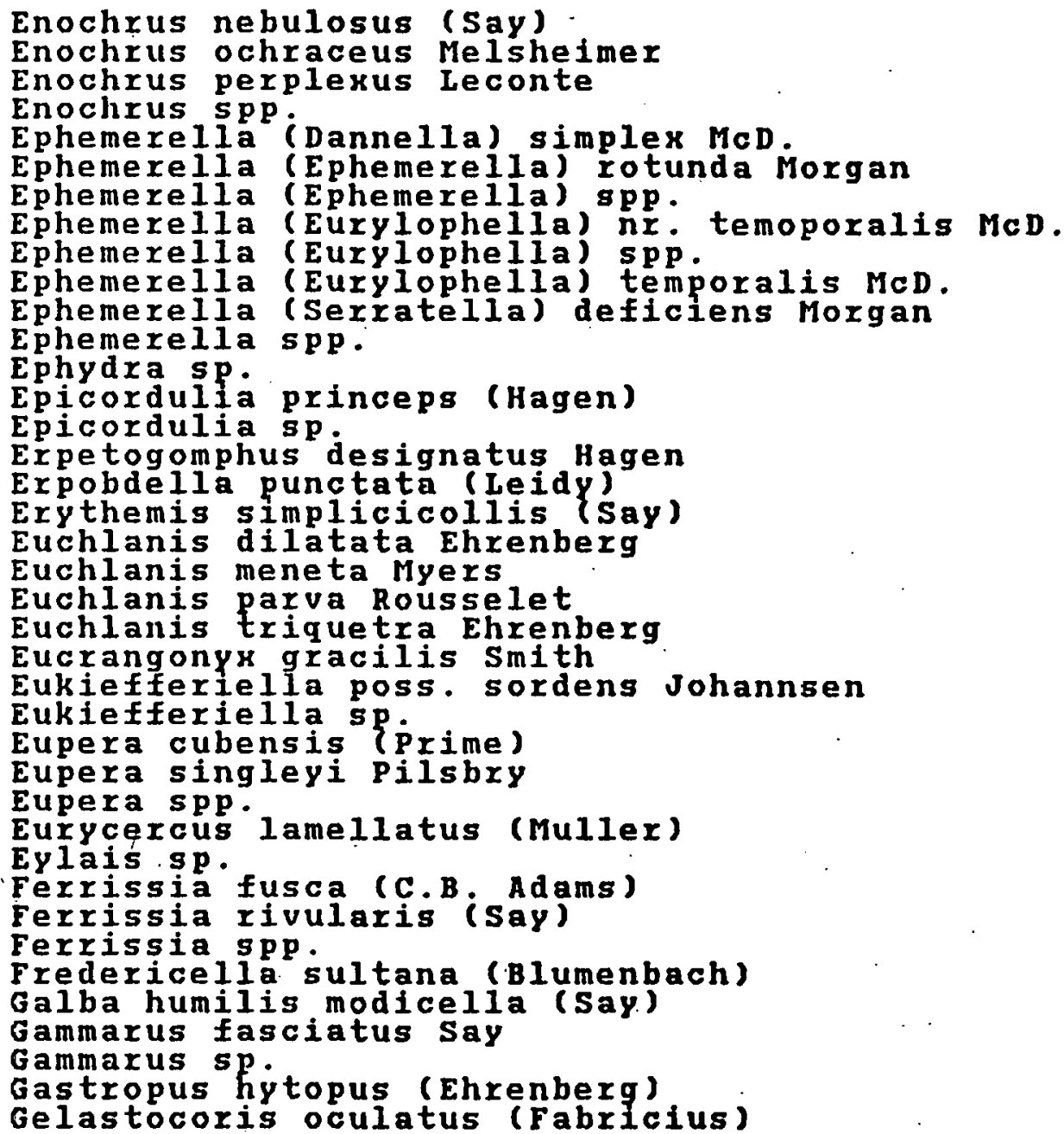

Gastropus hytopus (Ehrenberg)

Gelastocoris oculatus (Fabricius) 
APPENDIX A. SAVANMAH RIVER TAXONOMIC ACCESSION LIST

\title{
3. MACRO-INVERTEBRATES
}

\author{
NOMEKCLATURE
}

ACCESSION NO.

\section{GENUS \& SPECIES:}

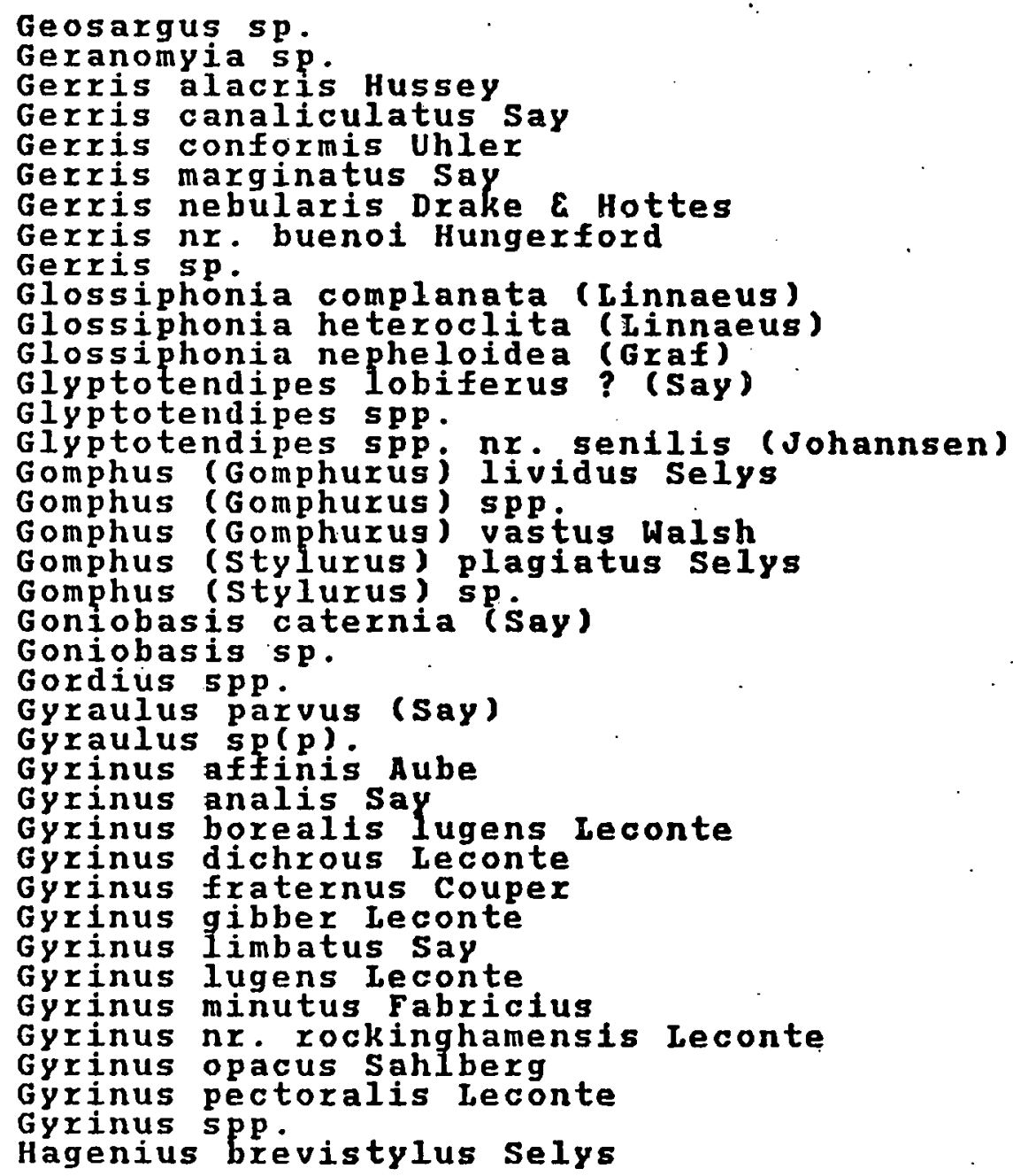




\section{APPENDIX A. SAVANKAH RIVER TAXONOMIC ACCESSION LIST}

3. MACRO-INVERTEBRATES

NOMENCLATURE

ACCESSION NO.

GENUS \& SPECIES:

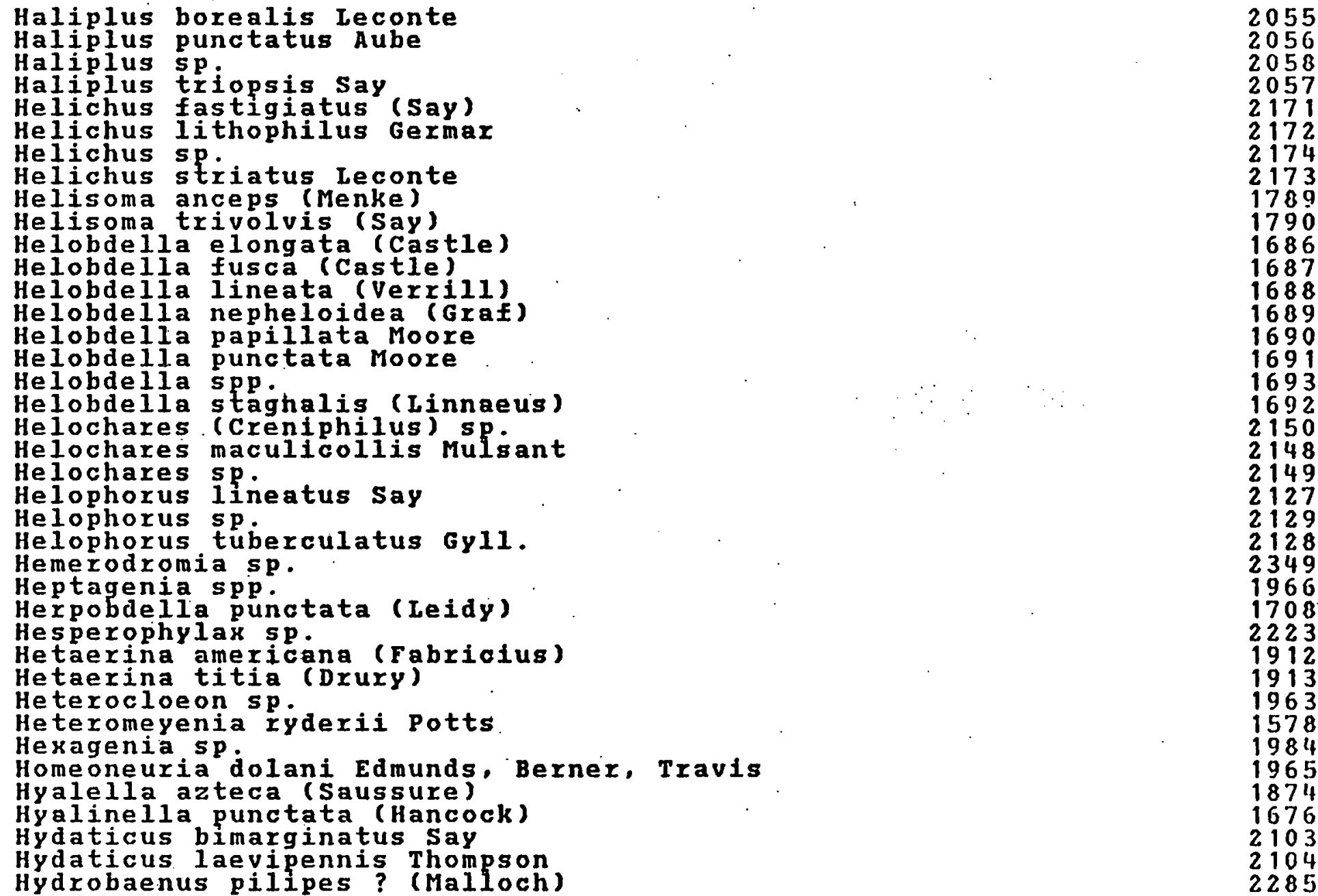




\section{MACRO-INVERTEBRATES}

\section{NOMENCLATURE}

ACCESSION NO.

\section{GENUS \& SPECIES:}

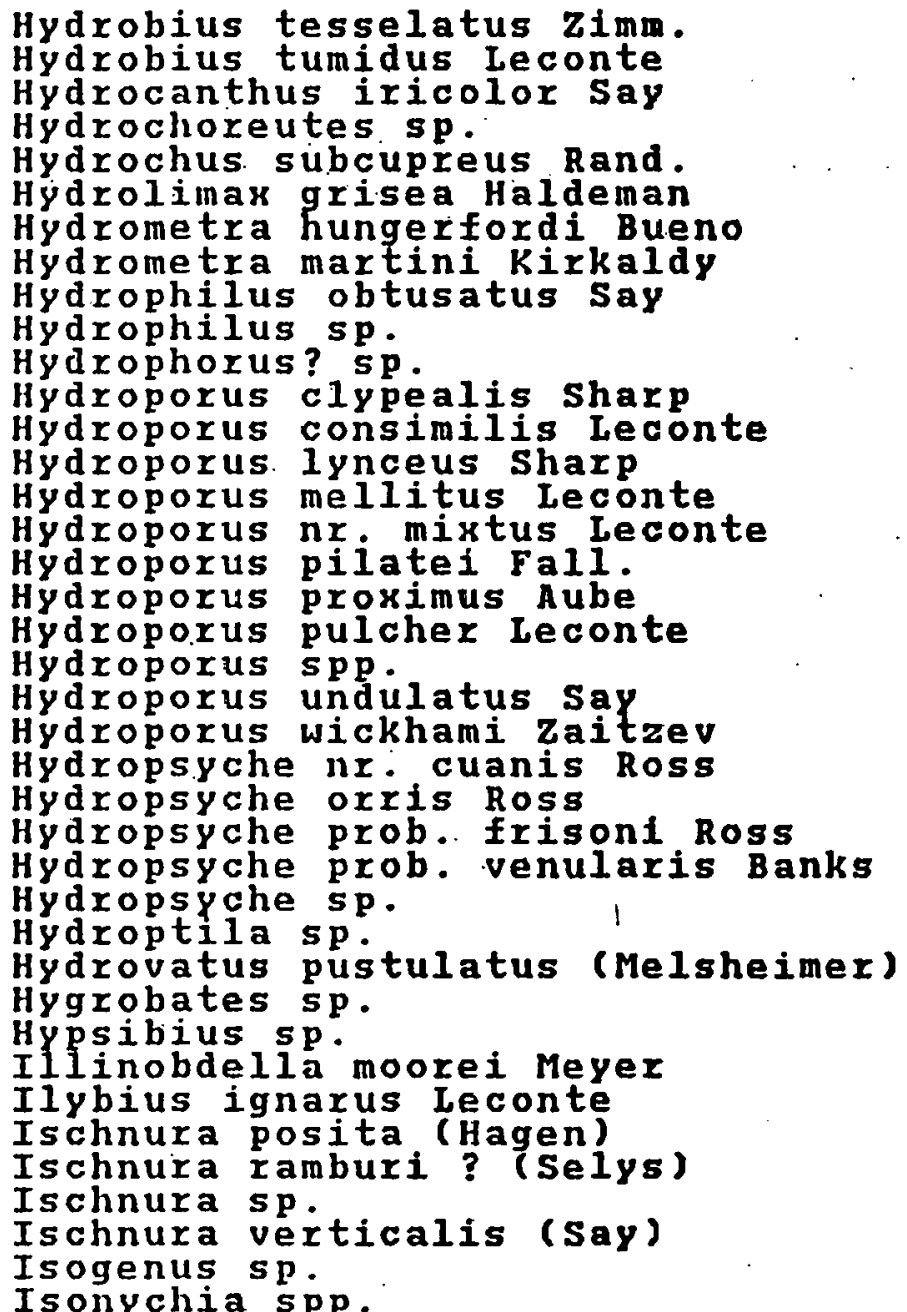




\section{APPENDIX A. SAVANMAH RIVER TAXONOMIC ACCESSION IIST}

3. MACRO-INVERTEBRATES

NOMENCLATURE

ACCESSION NO.

GENUS \& SPECIES:

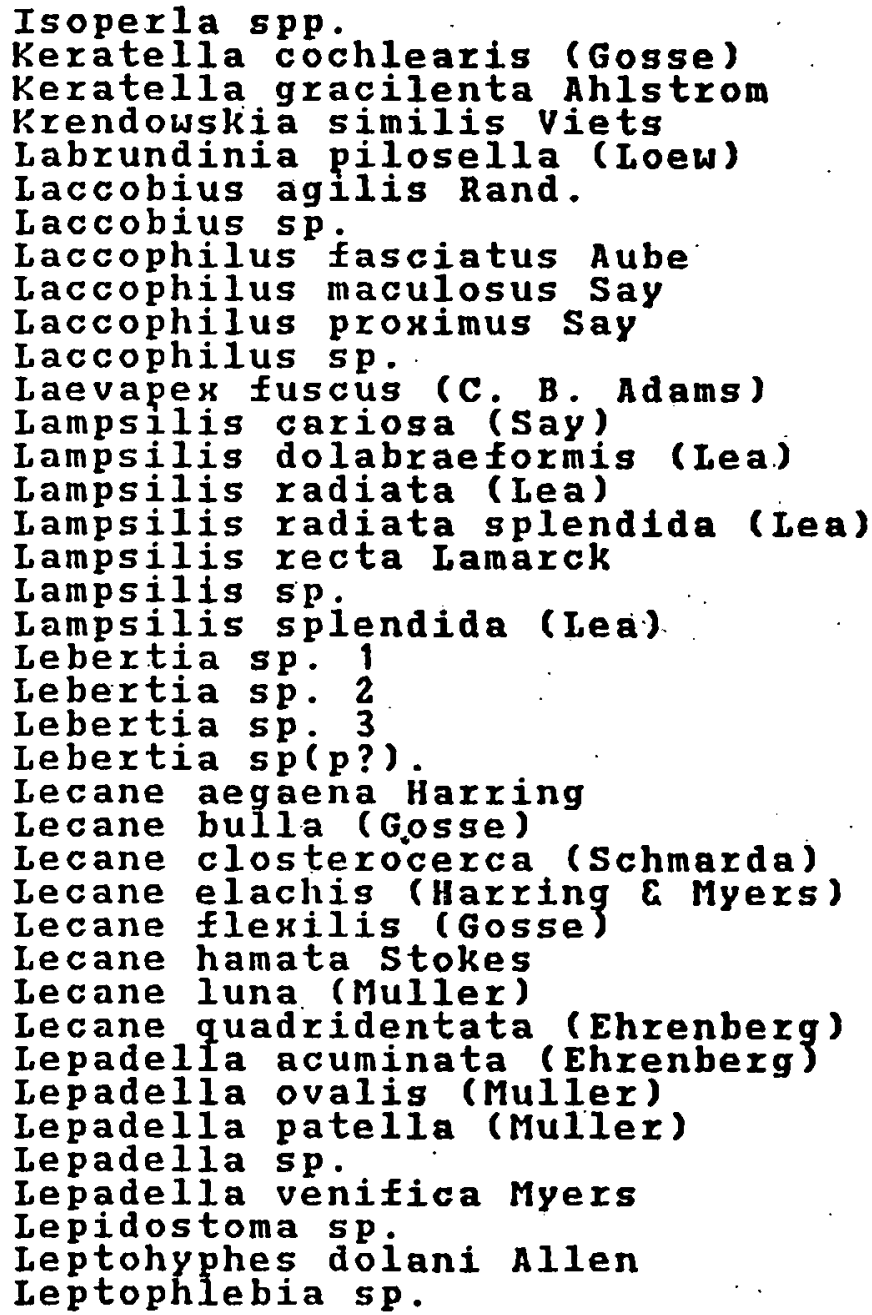




\section{:3. MACRO-INVERTEBRATES}

MOMENCLATURE

GENUS \& SPECIES:

Libeliula sp.

1953

limnephilus sp;

Limnesia sp(p?)

Limnodrilus hoftmeisteri claparede

Limnodrilus sp

limogonus hesione kirkaldy

Limogonus sp.

Iimonia sp

Lindia paliida Harring a Mers

Iirceus brachyurus (Harger)

lophopodelia carteri (Hyatt)

Lumbriculus inconstans smith

Lymnaea columella say

Iymnaea humilis say

Lymnaea sp.

Machronychus glabratus (say)

Machronychus .sp.

Macrobrachium acanthurus (Hiegmann)

Macrobrachium ohione (smith)

Macromia georgina (Selys)

Macromia sp.

Macromia taeniolata Rambur

Macronema carolina Banks

Macronema sp.

Macronema zebratum (Hagen)

Matus bicarinatus say

Megapus? sp

Menetus dilatatus (Gould)

Mesovelia bisignata uhler

Mesovelia mulsanti white

Metrobateg hesperius Uhler

Micrasema sp.

Microcylloepus pusillus (Leconte)

Micromya ogeecheensis (Conrad)

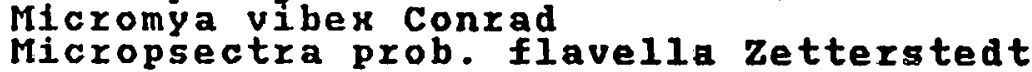


APPENDIX A. SAVANKAH RIVER TAXONOMIC ACCESSION IIST

\section{MACRO-INUERTEBRATES}

MOMENCLATURE

ACCESSION NO.

GENUS \& SPECIES :

Microvelia sp

Monommata astia Myers

Monommata sp.

Monopylephorus sp.

Monostyla Iunaris (Ehrenberg)

Mooreobdelia microstoma (Moore)

Mooreobdella sp(p?).

Musculium spp.

Musculium transversum (say)

Mystacides nr. sepulchralis (Walker)

Myzobdella lugubris leidy

Naidium osborni Walton

Naidium $s p(p$ ?).

Nais communis Piguet

Nais obtusa (Gexvais)

Nais sp(p?).

Nasiaeschra pentacantha (Rambur)

Nectopsyche nr. candida (Hagen)

Nectopsyche nx. exquisita (Walker)

Nectopsyche spp

Nemocapnia caroina Banks

Memoura sp.

Neoephemera sp.

Neoperia ciymene (Newman)

Neumania $s p$.

Neureclipsis sp

Neurocordulia molesta Walsh

Neurocordulia spina (Kellicott)

Notomita pachyura (Gosse)

Notonecta indica Linnaeus

Notonecta irroxata Uhler

Notonecta sp.

Notonecta uhieri kirkaldy

Nyctiophylar sp.

ochxotrichia sp

Oecetis inconspicua? (walker)

Oecetis nr. cinerascens (Hagen)

oecetis prob. eddlestoni Ross 
APPENDIX A. SAVANKAH RIVER TAXONOMIC ACCESSION LIST

3. MACRO-INVERTEBRATES

NOMENCLATURE

ACCESSION NO.

GENUS \& SPECIES :

Oecetis sp.

Omophron americanum Dejean

2240

ophidonais serpentina (Muller)

ophidonais sp(p?).

orthocladius nx. carlatus Roback

orthocladius nx. dorenus Roback

orthocladius nr. obumbratus Johannsen

orthocladius spp.

oxus sp.

Oxyethica sp.

Pachydiplar iongipennis (Burmeister)

Palaemonetes kadiakensis Rathbun

palaemonetes paludosus (Gibbes)

Palaemonetes spp.

Palmacorisa buenoi Abbott

paludicella articulata (Ehrenberg)

parachironomus nr. abortiva (Malloch)

Parachironomus tenuicaudata (Malloch)

Paracymus digestus (Leconte)

Paracymus spp.

Paracymus subcupreus (Say)

Paracymus suturalis (Ieconte)

Paragnetina kansensis Banks

Paxagnetina media (Walker)

paragnetina.nr. Kansensis Banks

Paragnetina sp.

Paraleptophlebia sp.

Parapoynx sp.

paratanytarsus spp.

Pectinatella magnifica Leidy

Pelocoris femoratus Palisot de Beauvais

Peloscolex multisetosus smith

Peloscolex spp

Peloscolex variegatus Leidy

Peltodytes (Cnemidotus) sp.

Peltodytes festivus (Wehncke)

peltodytes floridensis? Sanderson

Peltodytes littoralis Matheson

Peltodytes muticus (Leconte) 
APPENDIX A. SAVANKAH RIVER TAXONOMIC ACCESSION IIST

3. MACRO-INUERTEBRATES

HOMENCLATURE

ACCESSION MO.

GEMUS \& SPECIES:

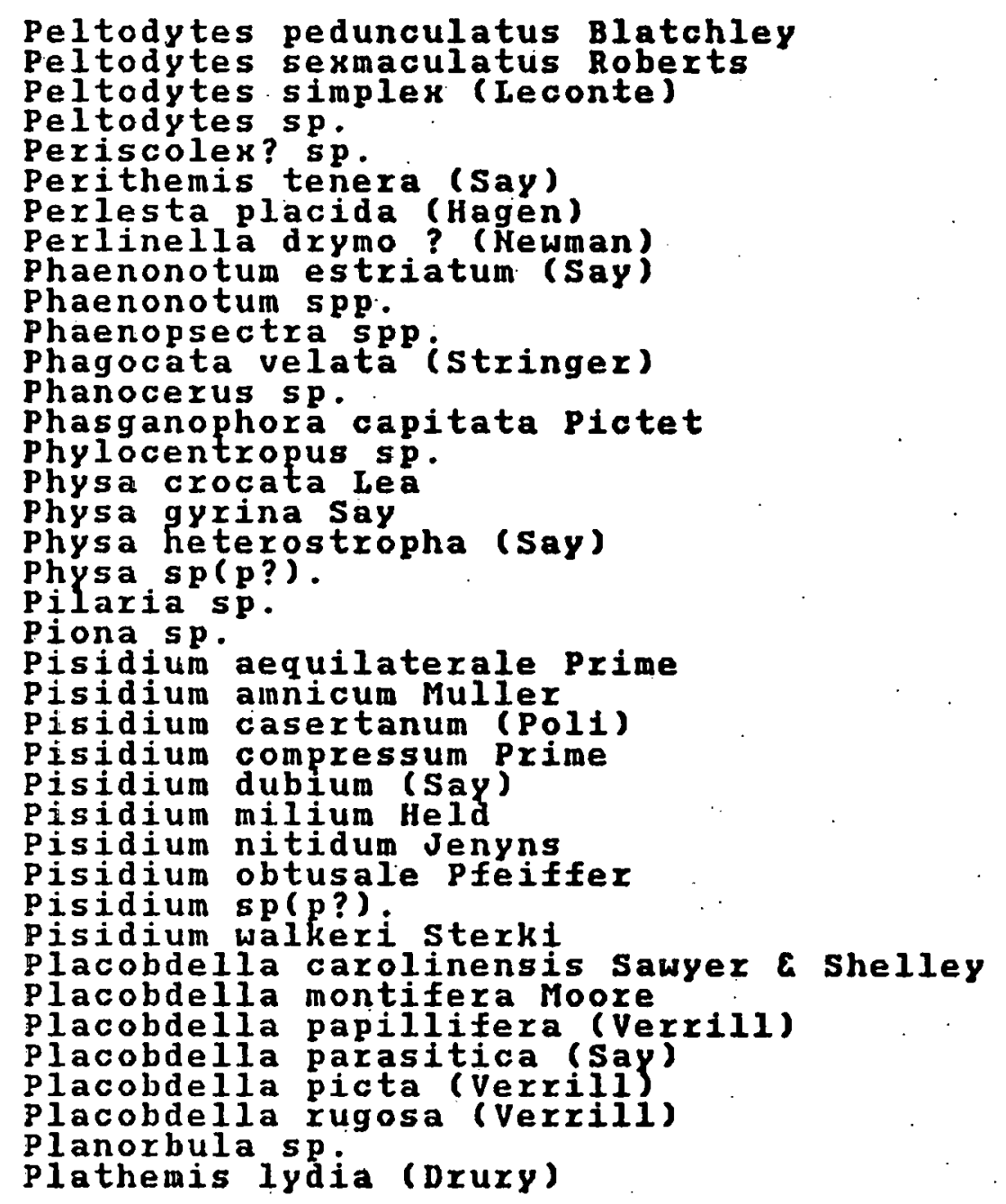


3. MACRO-INVERTEBRATES

MOMENCLATURE

ACCESSION NO.

GENUS \& SPECIES:

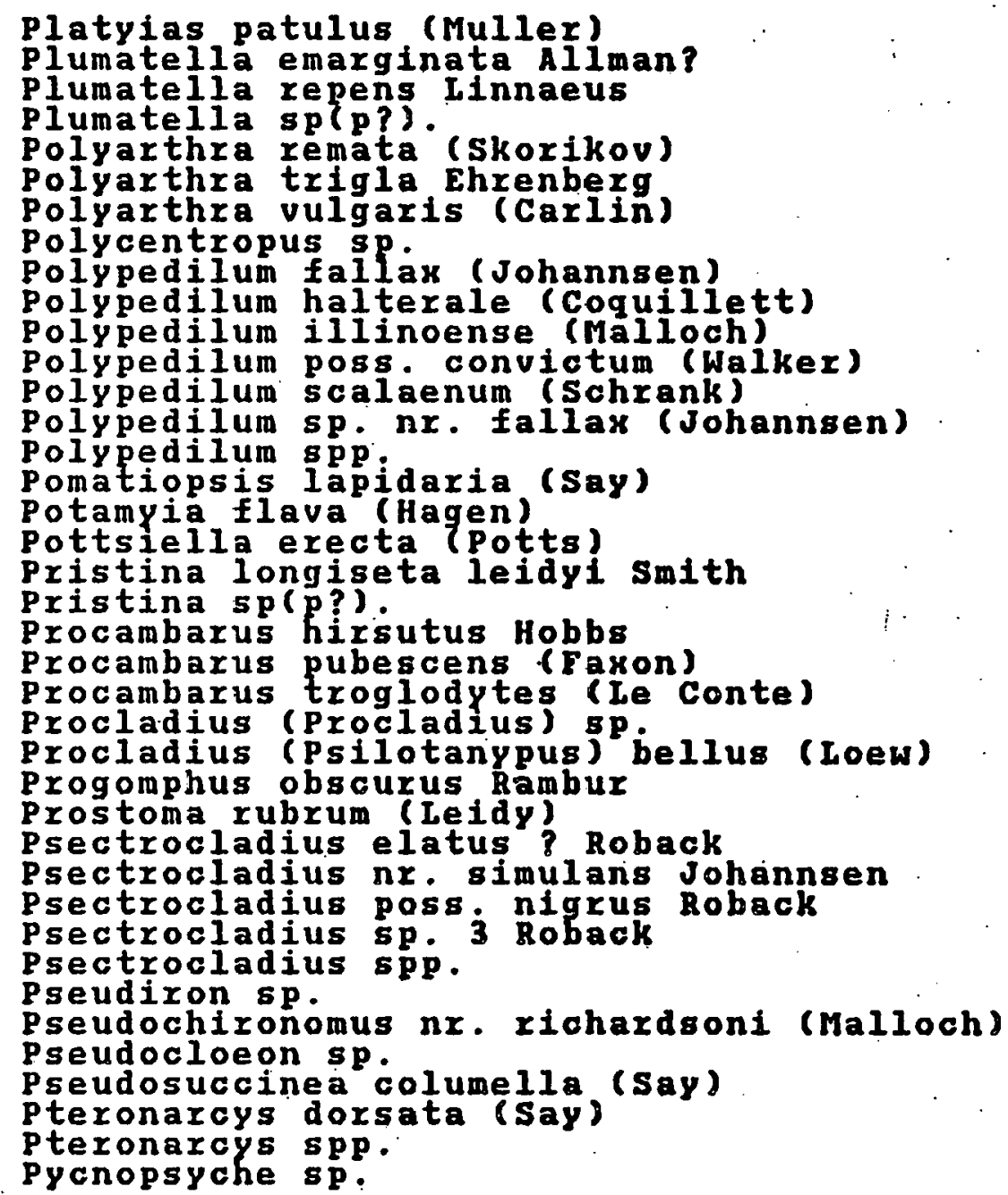




\section{APPENDIX A. SAVAKKAH RIVER TAXONOMIC ACCESSION IIST}

\section{MACRO-INVERTEBRATES}

NOMENCLATURE

ACCESSIOY No.

GENUS \& SPECIES :

quadrula sp.

Ranatra australis Hungerford

1838

Ranatra buenoi Hungertord

Ranatra fusca Hungerford

Ranatra kirkaldyi Bueno

Ranatra nigra Herr. $-\mathrm{Sch}$.

Rhagovelia obesa uhler

Rhanthus bistriatus Borgstrasser

Rheorthocladius spp.

Rhe otanytarsus exigua? Johansgen

Rheumatobates hungerfordi ? Wiley

Rheumatobates rileyi Bergroth

Rheumatobates $\mathbf{s p}$.

Rheumatobates tenuipes Meinext

Rhynchelmis elrodi ?? Smith \& Dickey

Rhynchelmis sp(p?).

Rhynchelmis tetratheca (Michaelsen)

Robackia claviger Townes

Scaridium longlcaudum (Mullex)

Sialis 5 p.

Sida crystallina (Mullex)

Sigara sp.

Simulium jenningsi (Malloch)

Simulium poss. decorum (Walker)

Simulium spp.

Sinantherina semibullata (Thorpe)

Siphlonurus sp. nr. marshalli Traver.

Slavina appendiculata (d'Udekem)

Somatogyrus virginicus walker

Sparganophilus $\mathbf{s p}$

Sphaerium lacustre (Muller)

Sphaerium securis prime

Sphaerium spp.

Sphaeriun transversum (say)

spongilla aspinosa potts

spongilla fragilis Leidy

spongila lacustris (Iinnaeus)

stenacron spp.

stenelmis antennalis sanderson 


\section{APPENDIX A. SAVANKAH RIVER TAXONOMIC ACCESSION IIST}

3. MACRO-INVERTEBRATES

NOMENCLATURE

ACCESSION NO.

GENUS \& SPECIES:

Stenelmis beameri sanderson

Stenelmis bicarinata leconte

Stenelmis convexula sanderson

stenelmis crenata (say)

Stenelmis decorata sanderson

Stenelmis douglasensis sanderson

Stenelmis fuscata (Blatchey)

Stenelmis grossa sanderson

stenelmis hungerfordi sanderson

stenelmis musgravei sanderson

stenelmis parva sanderson

Stenelmis quadrimaculatus Horn

stenelmis sinuata leconte

Stenelmis spp.

stenochixonomus sensu Johannsen

stenochironomus sp.

stenochironomus spp.

Stenonema spp.

stenos tomum $\mathbf{s}$.

stictochironomus devinctus (say)

strophitus undulatus (say)

stylaria fossularis Leidy

stylaria lacustris (Iinnaeus)

Suphisellus bicolor (Say)

Suphiselius gibbulus (Aube)

Synchaeta oblonga Ehrenberg

Synchaeta spi

2331

1745

1746

2069

2070

Tabanus $s p$.

Taeniopteryx prob. Ionicera Ricker $\varepsilon$ Ross

Tanypus punctipennis Meigen

Tanypus stellatus Coquiliett

Tanytarsus poss. gueria (Roback)

Tanytarsus spp.

Testudine1la patina (Hermann)

Tetragoneuria cynosura (Say)

Throscinus spp.

Tipula sp.

Tortopus poss. incertus Traver 
APPENDIX A. SAVANMAH RIVER TAXONOMIC ACCESSIOK IIST

3. MACRO-INVERTEBRATES

NOMENCLATURE

ACCESSION NO.

GENUS \& SPECIES:

Tortopus sp:

Trepobates inermis Esaki

$\mathbf{s p}$.

Trepobates subnitidus Esaki

Triaenodes sp.

Triaenodes tarda? Milne

Tribelos jucundus (Walker)

Trichocerca dixonnuttalii (Jennings)

Trichocerca rattus (Muller)

Trichocerca similis Wierzejski

Trichocerca sp.

Trichocerca tenuior (Gosse)

Trichocerca uncinata (Voigt)

Trichocladius sp.

Trichocorixa calva (Say)

Trichocorixa kanza sailer

Trichocorixa naias Kirkaldy

Trichotria similis (stenroos)

Tricorythodes spp.

Trochospongilla horrida (Weltner)

Trochospongilia leidyi (Bowerbank)

Tropisternus glaber Herbst

Tropisternus lateralis (Fabricius)

Tropisternus mixtus Leconte

Tropisternus spp.

Tropisternus striolatus reconte

Tropisternus sublaevis Leconte

Tubifex sp(p?).

Tubifes tubifes (Mullex)

Tyrrellia sp.

Undet. Genus (? Eriopterini tribe) sp.

Undet. Genus ("palpomyia groupn) spp.

Undet. Genus (nThienemannimyia gxoupi) spp.

Undet. Genus nr. Microtendipes sp.

Undet. Genus sp. a Roback

Uniomerus obesus (Iea)

Uniomerus tetralasmus (say)

Unionicola sp(p?).

valuata tricarinata (say)

1986

2021

2023

2022

2242

2.241

2332

1618

1618

1622

1620

1621

2297

2047

2048

2049

1653

1981

1582

1583

2161

2162

2163

2166

2164

2165

1726

1725

1902

2245

2256

2272

2335

2334

1839

1840

1908

1766 
APPENDIX A. SAVANKAH RIVER TAXOKOMIC ACCESSIOK IIST

\section{MACRO-INVERTEBRATES \\ MOMENCLATURE}

ACCESSTON MO.

GENUS \& SPECIES:

Velia brachialis? stal

villosa delumbis (Conrad)

viliosa viber (conrad)

xenochironomus renolabis (kieffer) 
Synonyms of the Phylum Mollusca according to Sam Fuller

Synonym

Campeloma sp.

Amnicola limosa (Say)

Amnicola (Lyogyrus) sp.

Goniobasis caternia (Say)

Lymnaea humilis Say

Lymnaea collumella Say

Laevapex fuscus (C. B. Adams )

Physa $s p(p$ ?).

Alasmidonta triangulata

(Lea)

Anodonta cataracta Say

Carunculina pulla (Conrad)

Lampsilis cariosa. (Say)

Lampsilis radiata splendida. (Lea)

Villosa delumbis (Conrad)

Villosa vibex (Conrad)

Elliptio lanceolata (Lea)

Elliptio complanata

(Lightfoot)

Elliptio congaraea (Lea)

Elliptio icterina (Conrad)

ID. No. Computer Nomenclature

1763

1764

1768

1769

1775

1777

1780

1781

1783

1793

1794

1795

1797

1800

1802

1805

1806

1809

1810

1813

1815

1816

1819

1826

1835

1821

1822

1829

1836

1824

1825

1827

1831

1833

1834

1837

1840
Campeloma decisum (Say)

C. lima Anthony

Amnicola n. sp. a

A. n. sp. b

Goniobasis sp.

Galba humilis modicella (Say)

Lymnaea sp.

Pseudosuccinea columella (Say)

Ferrissia fusca (C. B. Adams)

Physa crocata Lea

P. gyrina Say

P. heterostopha (Say)

Alasmidonta arcula Lea

Anodonta nr. cataracta Say

A. hallenbackii Lea

Carunculina parva (Barnes)

C. patrickae Bates

Lampsilis dolabraeformis (Lea)

L. radiata (Lea)

L. splendida (Lea)

Micromya ogeecheensis

M. vibrex (Conrad)

Elliptio arctatus (Conrad)

E. fisherianus Lea

E. productus (Conrad)

E. complanatus (Solander)

E. compalatus northamptonenes is

E. hopetonensis Lea

E. subinflatus (Conrad)

E. crassidens (Lamarack)

E. crassidens congareus Lea

E. forbesiana (Lea)

E. incrassatus Lea

E. lecontianus (Lea)

E. obnubilus (Lea)

E. tuomeyi (Lea)

Uniomerus tetralasmus (Say) 
Synonym

Corbicula fluminea (Muller) 1842

Eypera cubensis (Prime) 1844

Musculium transversum (Say) 1847

1858

1859

1860

1861

Pisidium compressum Prime

Pisidium amnicum Muller
ID. No. Computer Nomenclature

Corbicula manilensis (Philippi)

Eupera singleyi Pilsbry

E. spp.

Musculium spp.

Sphaerium lacustre (Muller)

$S$. securis Prime

S. transversum (Say)

S. spp.

Pisidium aequilaterale Prime

P. casertanum ( $P o l i$ )

P. milium Held

P. nitidum Jenyns

P. obtusale Pfeiffer

P. walkeri Sterki 
APPENDIX A. SAVANKAH RIVER TAXONOMIC ACCESSION IIST

4. PROTOZOA

MOMENCLATURE

ACCESSION NO,

PHYLUM :

Protozoa

3221

CIASS :

Ciliata

Mastigophora

Sarcodina

suctoria

3222

3351

ORDER :

Amoebida

Chloromonadida

Chrysomonadida

Cryptomonadida

Dinoflagelilia

Euglenoidida

Gymnos tomatida

Heliozoida

Heterotrichida

Hymenos tomatida

Hypotrichida

odontostomatida

oligotrichida

Peritrichida

Phytomonadida

Polymastigida

Proteomyrida

Protomonadida

Rhizomastigida

suctorida

Testacida

Tintinnida

Trichostomatida

3600

3357

3300

3223

3243

3304

3271

3424

3403

3520

3485

3546

3576

3536

3536

3581

3250

3344

3352

3323

3315

3601

3371

3542

3474

FAMILY :

Acanthocystidae

3404

Acinetidae 


\title{
APPENDIX A. SAVANKAH RIVER TAXONOMIC ACCESSIOK IIST
}

\section{PROTOZOA}

\author{
NOMENCLATURE
}

ACCESSION NO.

FAMILY :

Actinophryidae

Amoebidae

Amphileptidae

3358

Amphimonadidae

3425

Anisonemidae

Arcellidae

Aspidiscidae

Astasiidae

Bicosoecidae

Bodonidae

Bursariidae

Carteriidae

Chlamydodontidae

Chlamydomonadidae

Chloromonadae

Chromulinidae

Ciliophryidae

clathrelidae

clathrulinidae

codosigidae

Coelos omididae

Cohnilembidae

Colepidae

Colpodidae

Condylos tomidae

cryptomonadidae

Cystodinitare

Dendrosomatidae

Didiniidae

Difflugiidae

Dysteridae

Epalkellidae

Epistylidae

Euglenidae

Euglyphidae

Euplotidae

Frontoniidae

3224

3414

3416

3337

3475

3486

3433

3477

3525

3244

3305

3608

3435

3381

3439

3577

3582

3393

3549

Gromidae

3489

Gymnodinitae 


\section{APPENDIX A. SAVAKKAH RIVER TAXONOMIC ACCESSIOK IIST}

4. PROTOZOA

MOMENCLATURE

ACCESSION NO.

FAMIIY:

Halteriidae

3537

Heterophryidae

Hexamitidae

Holophryidae

Lithocolidae

Loxodidae

Mastigamoebidae

Mayorellidae (=Paramoebidae, in Page)

Metopidae

Microthoracidae

Monadidae

Multiciliidae

Kaegleriddae

Kassulidae

ochromonadidae

oikomonadidae

ophrydidare

ophryoglenidae

oxytrichidae

Parameciidae

Peridiniidae

Phacotidae

Philasteridae

Pleuronematidae

Podophxyidae

spathididae

spirostomatidae

spirozonidae

stentoridae

Strobilidiidae

syncryptidae

Tetrahymenidae

Tetramitidae

Tintinnidae

Tracheliidae

Trimastigidae

Vaginicolidae

Vampyrelidae

3345

3441

3420

3456

3316

3367

3527

3340

3321

3369

3458

3230

3342

3589

3501

3551

3312

3262

3505

3507

Volvocidae 
14. PROTOZOA

NOMENCLATURE

FAMILY:

Vorticellidae

GENUS \& SPECIES:

Acanthamoeba castellanii (Douglas)

Acanthamoeba hyalina (Dob. E o Conn.)

Acanthamoeba sp.

Acanthocystis aculeata Hart. E Less.

Acanthocystis turfacea (cart.)

Acineta $8 \mathrm{pp}$.

Actinophrys sol Ehr.

Actinophrys $5 \mathrm{pp}$

Actinophrys vesiculata Pen.

Actinosphaerium eichhorni Ehr

Amoeba discoides Schaef.

Amoeba dubia Schaef.

Amoeba gorgonia Pen.

Amoeba guttula Duj.

Amoeba limicola Rhumb.

Anoeba proteus (Pallas)

Amoeba radiosa Ehr.

Amoeba $\mathbf{s p p}$.

Amoeba spumosa Gruber

Amoeba striata Pen.

Amoeba verrucosa Ehr.

Amoeba vespertilio Pen

Amoeba villosa Wall. (=Trichamoeba villosa Wall., in Page)

Amphidinium sp.

Amphileptus claparedei stein

Amphisiella oblonga Schew.

Amphisiella sp.

Anarma brevis Goodr. E Jahn

Ancyromonas contorta (klebs)

Anisonema acinus Duj.

Anisonema emarginatum stokes

Anisonema ovale Klebs

Anisonema pusillum stokes

Anisonema truncatum stein

Anthophysis steini senn 
APPENDIX A. SAVAMKAH RIVER TAXONOMIC ACCESSIOK IIST

4. PROTOZOA

MOMENCLATURE

ACCESSION NO.

GENUS $\varepsilon$ SPECIES:

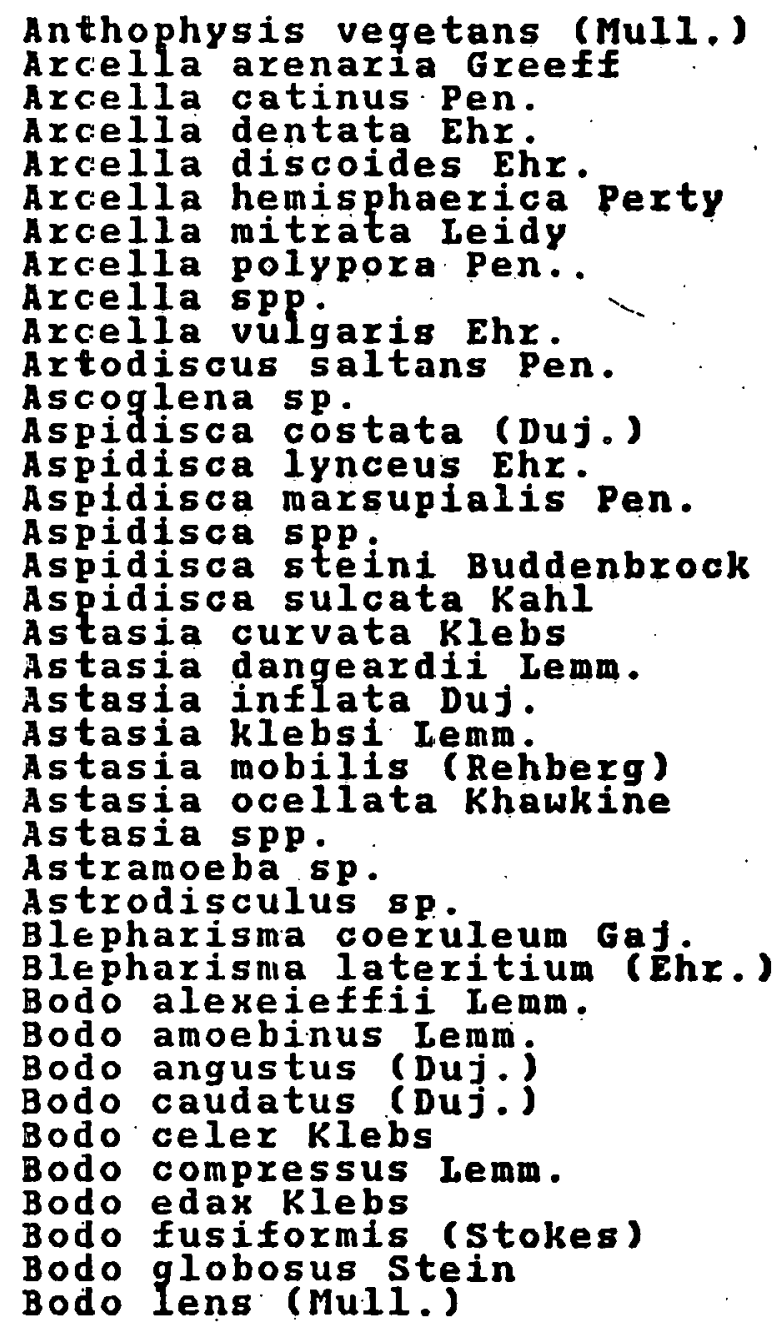


4. PROTOZOA

NOMENCLATURE

ACCESSION NO.

GENUS \& SPECIES:

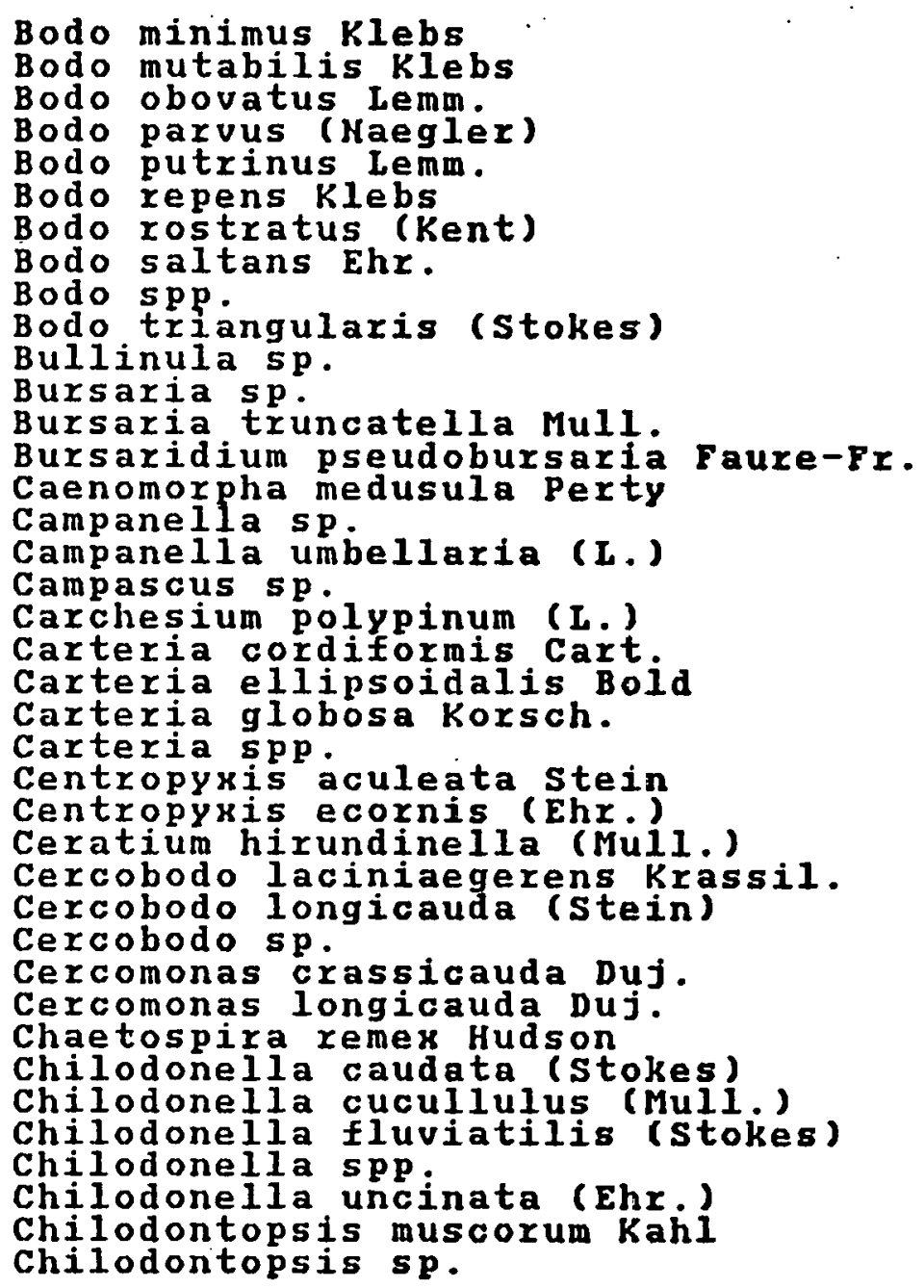




\section{APPEKDIX A. SAVAKKAH RIVER TAXONOMIC ACCESSION LIST}

\section{PROTOZOA}

NOMENCLATURE

\section{GENUS \& SPECIES:}

Chilodontopsis voras (stokes)

Chilomonas paramecium Ehr.

Chilophrya labiata (Edmondson)

Chlamydodon sp.

Chlamydomonas angulosa Dill.

Chlamydomonas compressa Pasch.

Chlamydomonas conica Dang.

Chlamydomonas depauperata pasch.

chlamydomonas globosa snow

Chlamydomonas gracilis snow

Chlamydomonas monadina stein

Chlamydomonas pomiformis pasch.

Chlamydomonas regularis Korsch.

Chlamydomonas sectilis Korsch.

Chlamydomonas snowiae Printz

Chlamydomonas spp.

Chlamydomyra montana lankester

Chlamydophrys stercorea cienk.

Chlorogonium elegans Playf.

Chlorogonium sp.

chromulina ovalis klebs

Chromulina rosanoffii Butschli

Chromulina spp.

Chroomonas norstedtii Hansgirg

Chrysosphaerella spp.

Ciliophrys infusionum Cienk.

cinetochilum margaritaceum perty

cladomonas fruticulosa stein

cladonema pauperum Pasch.

Clathrella foreli Pen

Clathrulina elegans (Leidy)

climacostomum sp.

CIypeolina marginata pen.

Coccomonas orbicularis stein

Cochliopodium bilimbosum (Auerbach)

Cochliopodium digltatum (Greeff

1153

Codonella cratera (Leidy)

1154

Codonoeca sp.

Cohnilembus fusiformis (Cohn) 


\section{APPENDIX A. SAVANKAH RIVER TAXONOMIC ACCESSTOK LIST}

4. PROTOZOA

NOMENCLATURE

ACCESSION NO.

GENUS \& SPECTES:

Coleps bicuspis Noland

Coleps elongatus Ehr.

Coleps hirtus (Muli

Coleps octospinus Moland

Coleps spp.

Coleps striatus smith

Colpidium campylum (stokes)

Colpidium colpoda (Ehx.)

Colpoda aspera Kahl

Colpoda cuculius Mull.

Colpoda henneguyi Fabie-Dom.

Colpoda inflata (stokes)

Colponema loxodes stein

Colponema $\mathbf{s p}$

Condylostoma sp.

Copromonas subtilis Dob.

cothurnia annulata stokes

Cothurnia ovata Fromentel

Cothurnia pupa Eichwald

Cothurnia sp.

Cranotheridium taeniatum schew.

Cristigera phoenix Pen.

Crobylura pelagica Andre

cryptochrysis commutata Pasch.

cryptochrysis polychrysis Pasch.

Cryptoglena pigra Ehr.

Cryptoglena spp.

Cryptomonas compressa Pasch.

Cryptomonas erosa Ehr.

Cryptomonas nasuta pasch.

Cryptomonas obovoidea Pasch.

Cryptomonas ovata Ehr.

Cryptomonas reflexa Marsson

Cryptomonas spp.

Cucurbitelia mespiliformis pen.

Cyathomonas truncata Ehr.

Cyclidium brandoni Kahl

Cyclidium citrullus Cohn

Cyclidium elongatum schew.

1234

1235

1237

1239

1238

1373

1374

314

1315

1316

1097

1098

937

1525

1526

1527

1528

1290

1359

1248

864

865

949

867

868

869

870

871

872

1165

873

1360

1361

1362 


\section{APPENDIX A. SAVAKNAH RIVER TAXONOMIC ACCESSTOM LIST}

4. PROTOZOA

NOMENCLATURE

ACCESSION NO.

GENUS \& SPECIES:

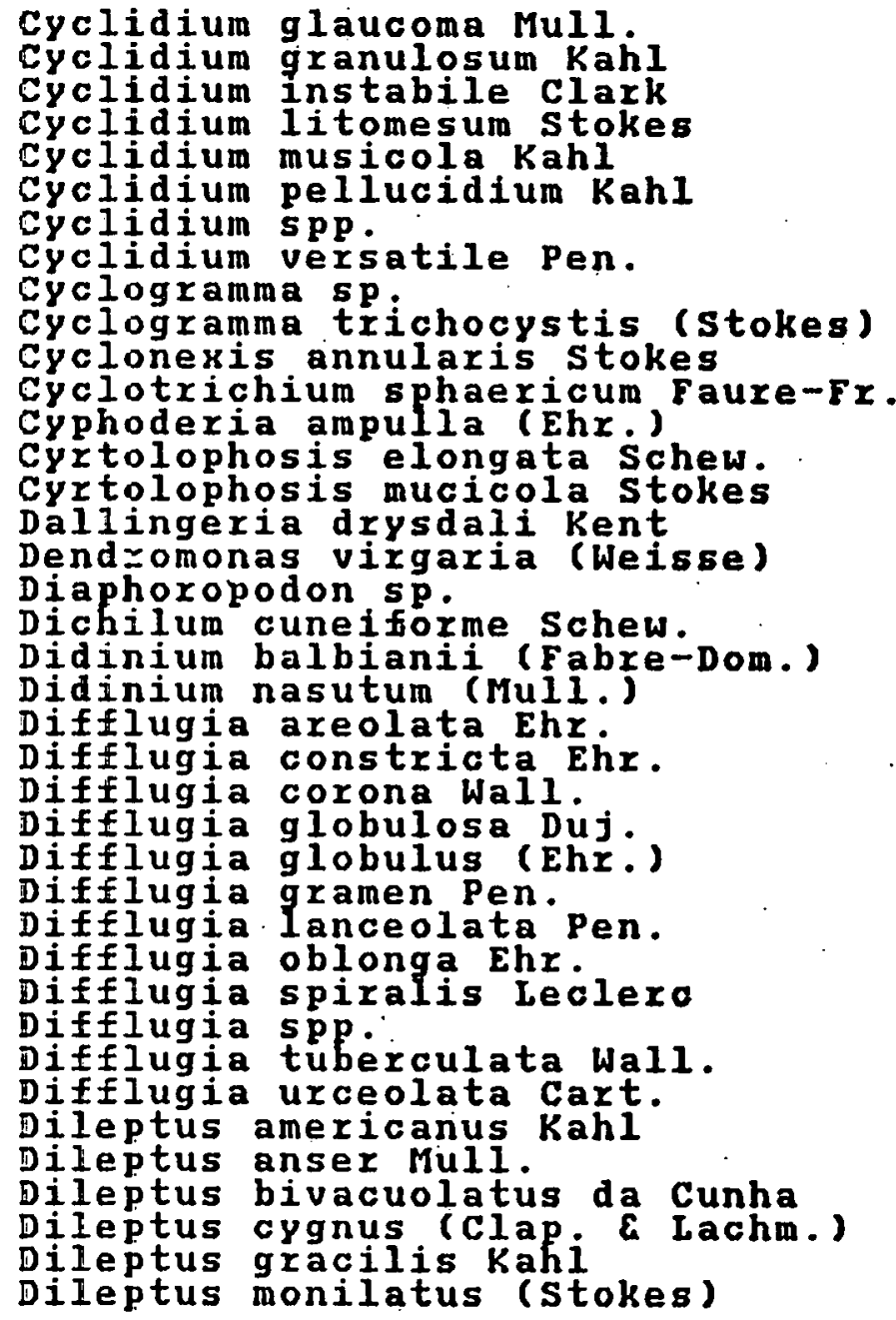

1363

1364

1365

1366

1367

1368

1370

1369

1284

1283

840

1240

1185

1329

1330

1108

841
1166

1375

1241

1242

1167

1168

1169

1170

1171

1172

1173

1174

1175

1178

1176

1177

1303

1304

1305

1306

1307

1308 
APPENDIX A. SAVANKAH RIVER TAXONOMIC ACCESSION LIST

4. PROTOZOA

NOMENCLATURE

ACCESSION NO.

GENUS \& SPECIES:

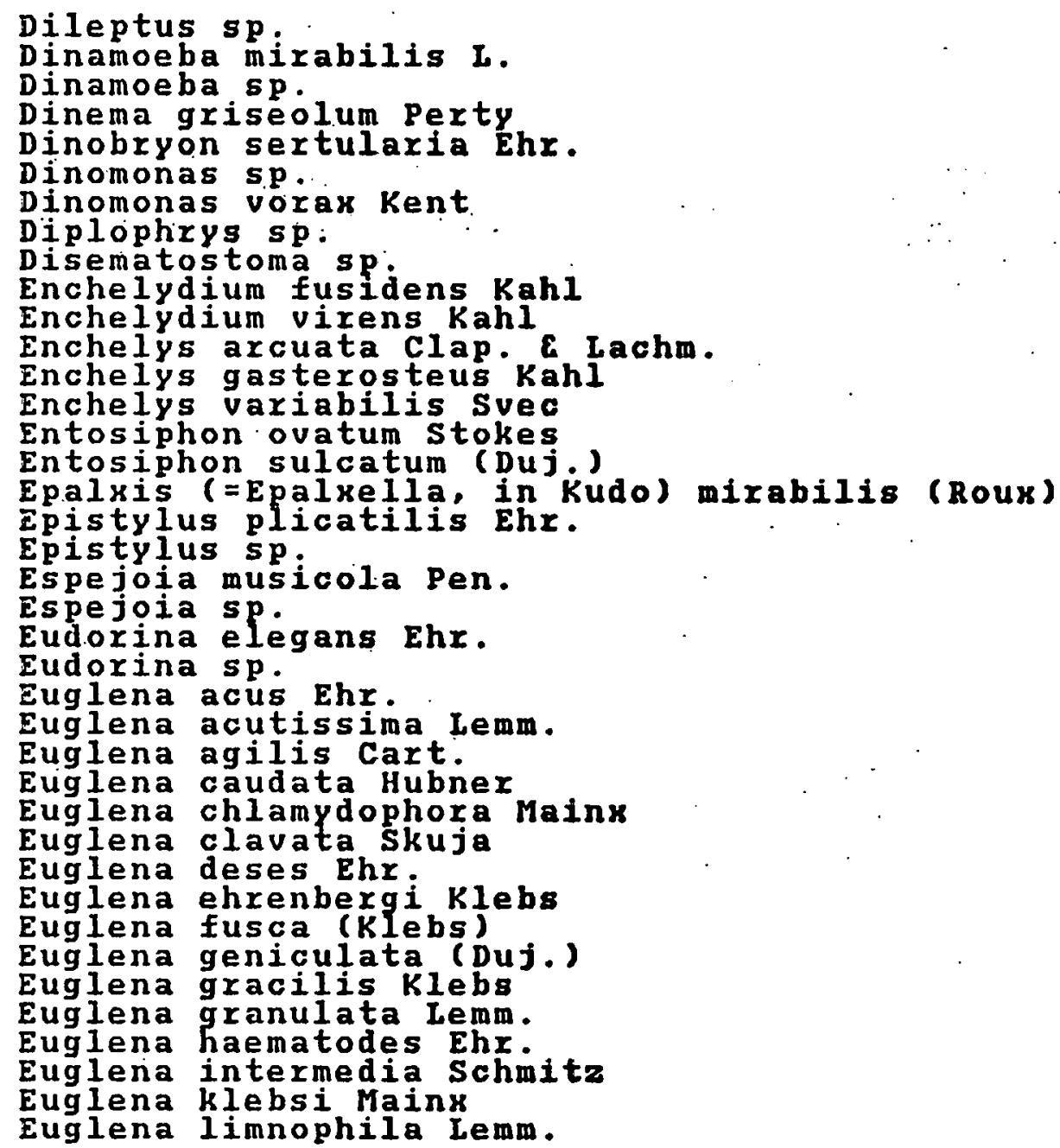

1309

1131

1132

912

842

1070

1069

1198

1331

1291

292

1249

1250

1251

913

914

1513

1518

1519

1332

1333

899

900

951

952

953

954

955

956

958

959

960

961

962

963

964

965

966 
APPENDIX - A. SAVANKAH RIVER TAXONOMIC ACCESSIOK IIST

4. PROTOZOA

MOMENCLATURE

ACCESSION NO.

\section{GENUS \& SPECIES :}

Euglena minima France

Euglena minuta Prescott

Euglena mutabilis mainxi Gojd.

Euglena mutabilis Schmitz

968

970

Euglena oxyuris Schmarda

Euglena pisciformis klebs

Euglena platydesma skuja

Euglena prorima Dang.

Euglena rubra Hardy

Euglena sanguinea Ehr.

Euglena sociabilis Dang.

Euglena spirogyra Ehr.

Euglena splendens Dang.

Euglena spp.

Euglena terricola (Dang.)

Euglena torta Korsch.

Euglena tripteris (Duj.)

Euglena truncata Malton

Euglena viridis Ehr.

Euglenopsis.vorar.kiebs

Euglypha acanthophora Ehx

Euglypha cristata Leidy

Euglypha elongata Leidy

Euglypha mucronata leidy

Euglypha scutigera Pen.

Euglypha spp

Euplotes aediculatus Pierson

Euplotes affinis Duj.

Euplotes carinatus stokes

Euplotes eurystomus wrzes.

Euplotes leticiensis Bovee

Euplotes moebiusi Kahl

Euplotes muscicola Kahl

Euplotes patelia (Muli.)

Euplotes plumipes stokes

Euplotes spp.

Euplotes tayiori Garnjobst

Eutreptia viridis Perty

Flabeliula velata Jahn 
4: PROTOZOA

MOMENCLATURE

GENUS \& SPECIES :

Frontonia acuminata (Ehr.)

Frontonia acuminata angusta Kahl

1334

Frontonia depressa (stokes)

Frontonia elliptica Beardsiey

Frontonia leucas Ehr.

Frontonia spp.

Frontonielia complanata Wetzel

Gastrostyla musoorum Kahl

Gastrostyla steini Engelmann

Gigantochloris sp.

Giaucoma aveliana Kahl

Glaucoma reniformis schew.

Glaucoma scintillans. Ehr.

Glaucoma setosa schew.

Glaucoma spp.

Glenodinium cinctum Ehr.

Glenodinium neglectum Schilling

Gonium formosum Pasch.

Gonium pectorale Muli.

Gonostomum affine (stein)

Gonostomum strenuum (Engelmann)

Gonyostomum semen Diesing

Gonyostomum sp.

Gromia nigricans (Pen.)

Gymnodinium aeruginosum stein

Gymnodinium fuscum Ehr.

Gymnodinium palustre schiling

Gymnodinium rotundatum klebs

Gymnodinium spp.

Gyrodinium hyalinum schilling

Hallezia brachypoda (stokes)

Halteria grandinella (Mull.)

Hartmannelia hyalina Dang.

Heleopera sp.

Hemicycliostyla sp.

Hemicycliostyla sphagni stokes

Heterochromonas (=Monas, in Pascher) ap.

Heteronema acus (Ehr.)

Hetexonema acutissimum Lemm. 


\title{
APPENDIX A. SAVAKMAH RIVER TAXONOMIC ACCESSION IIST
}

\section{PROTOZOA}

\author{
NOMENCLATURE
}

\section{GENUS \& SPECIES}

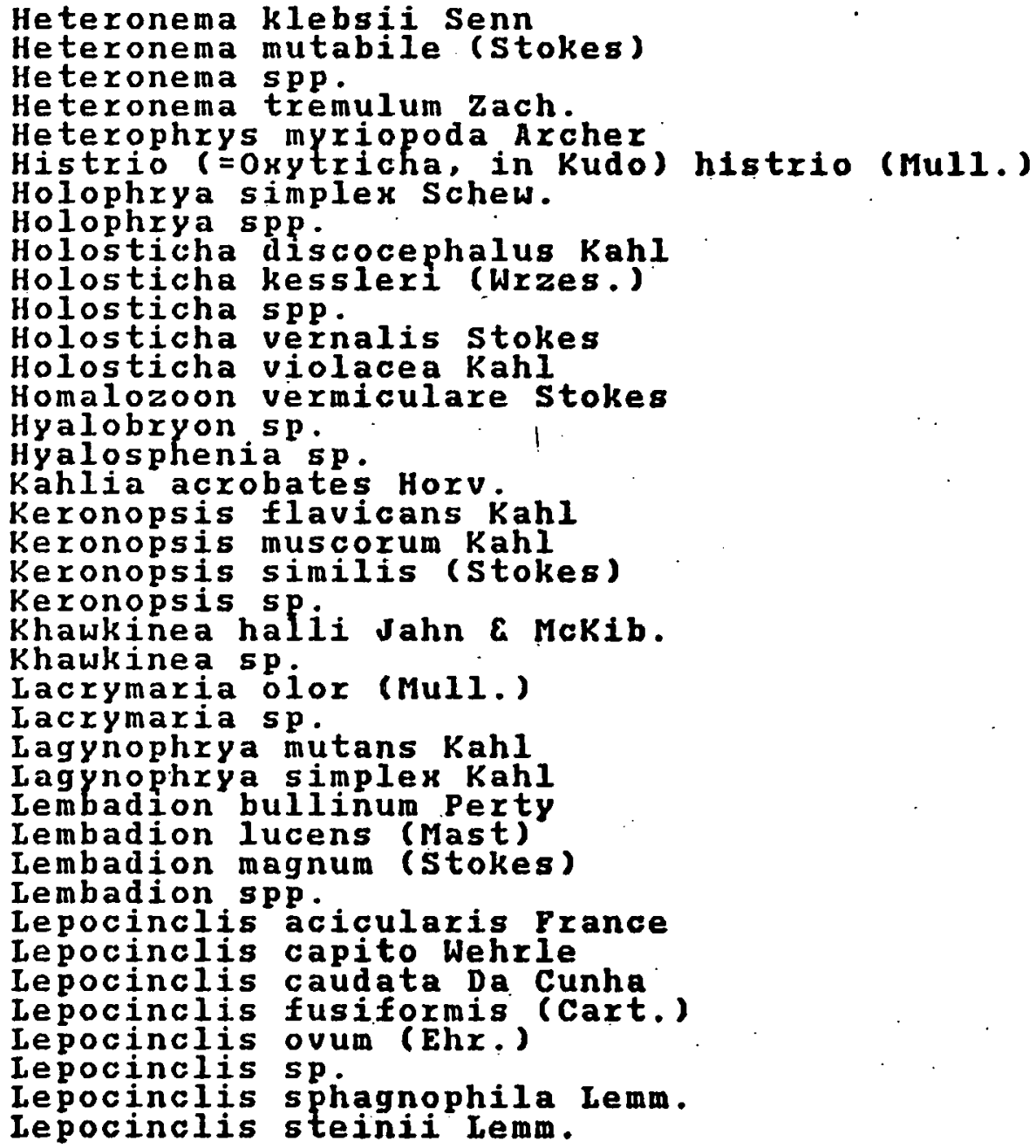


4. PROTOZOA

NOMENCLATURE

ACCESSION NO.

GENUS \& SPECIES :

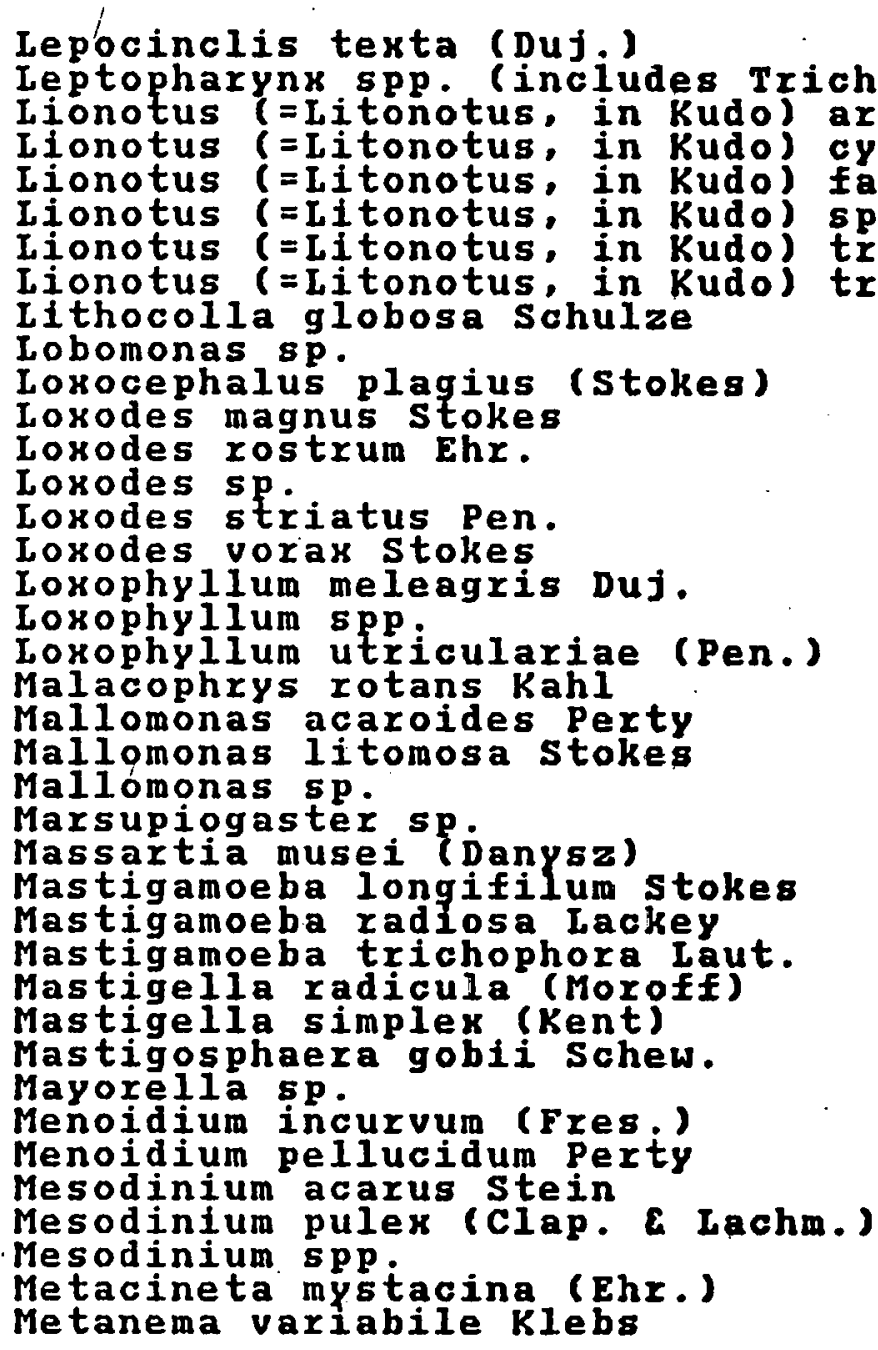




\section{APPENDIX A. SAVANMAH RIVER TAXONOMIC ACCESSION LIST}

\section{PROTOZOA}

KOMEKCLATURE

GENUS \& SPECIES:

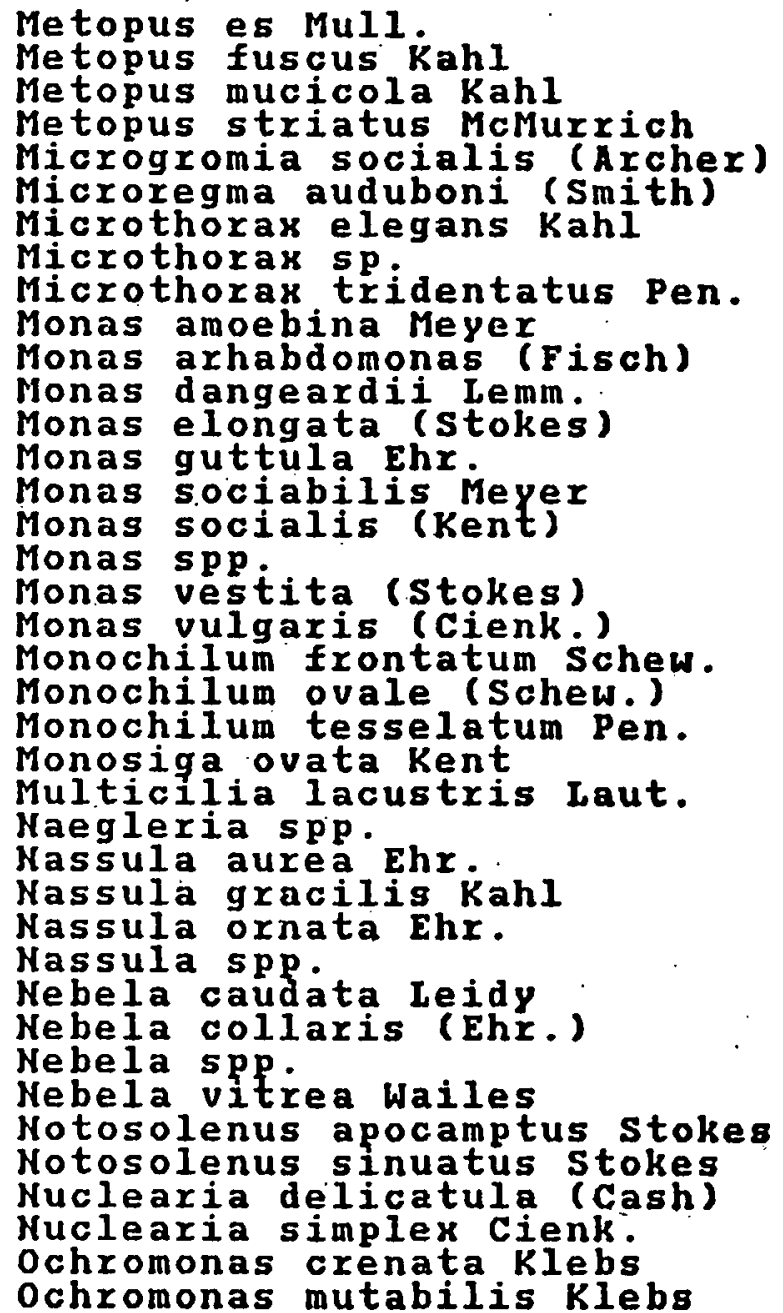




\section{APPENDIX. A. SAVANKAH RIVER TAXONOMIC ACCESSION IIST}

4.. PROTOZOA

MOMENCLATURE

ACCESSION NO.

GENUS \& SPECIES:

Ochromonas spp.

Oikomonas mutabilis kent

oikomonas obliqua kent

oikomonas quadrata kent

oikomonas socialis Moroft

oikomonas spp.

oikomonas termo (Ehr.)

onychodromopsis flexilis Maupas

Onychodromus grandis stein

opercularia plicatilis stokes

ophrydium vernalis (stokes)

ophryoglena atra Iieberkuhn

Opisthotricha (=0xytricha, in Kudo) procera Kahl

opisthotricha (=0xytricha, in Kudo) similis Engelmann

orthodonelia sp

oxytricha bifaria stokes

oxytricha chlorelilgera Kahl

oxytricha fallax stein

oxytricha furcata smith

oxytricha hymenostoma stokes

oxytricha ludibunda stokes

oxytricha minor Kahl

oxytricha setigera. Stokes

Oxytricha sp.

oxytricha tricornis Milne

Pamphagus mutabilis Bailey

Pandorina morum (Muli.)

Paracineta spp.

Paradileptus robustus Wenrich

Paraholosticha herbicola Kahl

Paramastix conifera skuja

Paramecium aurelia Ehr

Paramecium bursaria (Ehr.)

Paramecium calkinsi Woodruff

Paramecium caudatum Ehr.

Paramecium multimicronucleatum Powers \& Mitchell

Paramecium putrinum Clap. E Iachm.

Paramecium trichium stokes 
APPENDIX A. SAVANMAH RIVER TAXONOMIC ACCESSTOK LIST

4. PROTOZOA

NOMEUCLATURE

$: \quad, \ldots 1, \ldots, 1$

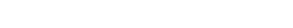

GENUS \& SPECIES :

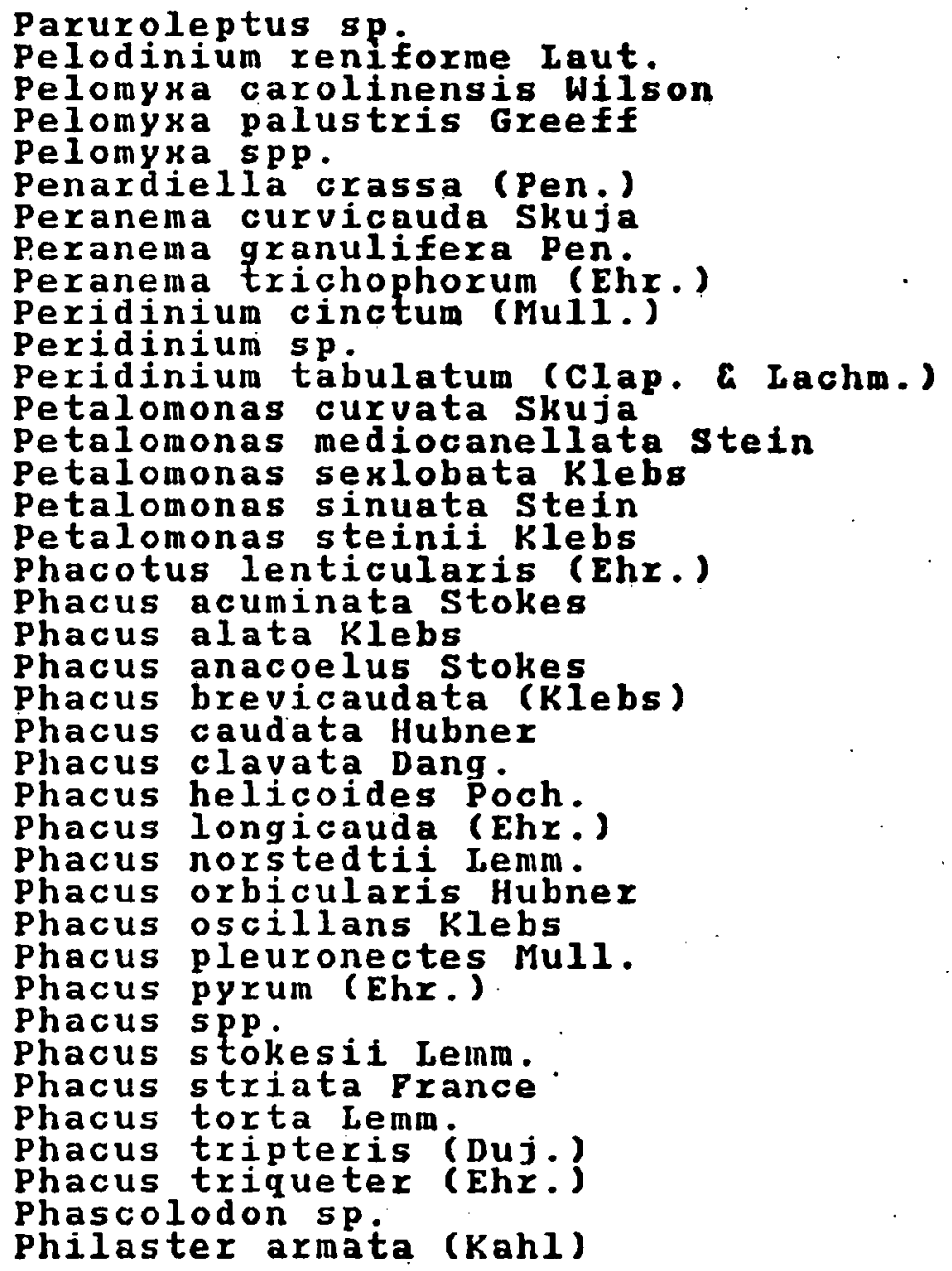




\section{APPENDIX A. SAVANKAH RIVER TAXOKOMIC ACCESSION IIST}

4. PROTOZOA

NOMENCLATURE

ACCESSION NO.

GENUS \& SPECIES :

Phryganella paradoxa Pen.

Phyllomitus amylophagus Klebs

Pithothorax simplex Kahl

Placus ovum Kahl

Placus sp.

Placus striatus France

Plagiophrys parvipunctata Pen.

Platycola sp.

Platydorina caudata Kofoid

Platynematum sociale (Pen.)

Platynematum sp.

platyophrya lata Kahl

Pleodorina sp.

Pleuromonas jaculans (Perty)

Pleuronema crassum Duj.

Pleuronema sp.

Pleurotricha grandis stein

Pleurotricha lanceolata (Ehr.)

Podophrya fixa Muli.

Podophrya sp.

Polytomella sp.

Pompholyxophrys punicea Archer

Pontigulasia elisa schouteden

Proxodon discolor Ehr.

Prorodon griseus (Clap. \& Lachm.)

Prorodon margaritifer clap. E Iachm.

Prorodon minutus Kahl

Prorodon ovum Ehr.

Prorodon sp.

Pseudochlamys sp

Pseudodifflugia fulva Archer

Pseudodiftlugia gracilis Schlum.

Pseudodifflugia spp.

Pseudoglaucoma muscorum Kahl

Pseudoinicrothorax agilis Mermod

Pseudomicrothoras dubius (Maupas)

Pseudomicrothorar sp.

Pseudoprorodon farctus (clap. E Lachm.)

pteridomonas $\mathbf{s p}$.

1259

1260

1262

1261

1157

1529

905

1346

1347

1263

906

1100

1371

1372

1483

1484

1569

1570 
APPENDIX A. SAVAKKAH RIVER TAXOKOMIC ACCESSION IIST

4. PROTOZOA

MOMENCLATURE

ACCESSION NO.

GENUS \& SPECIES:

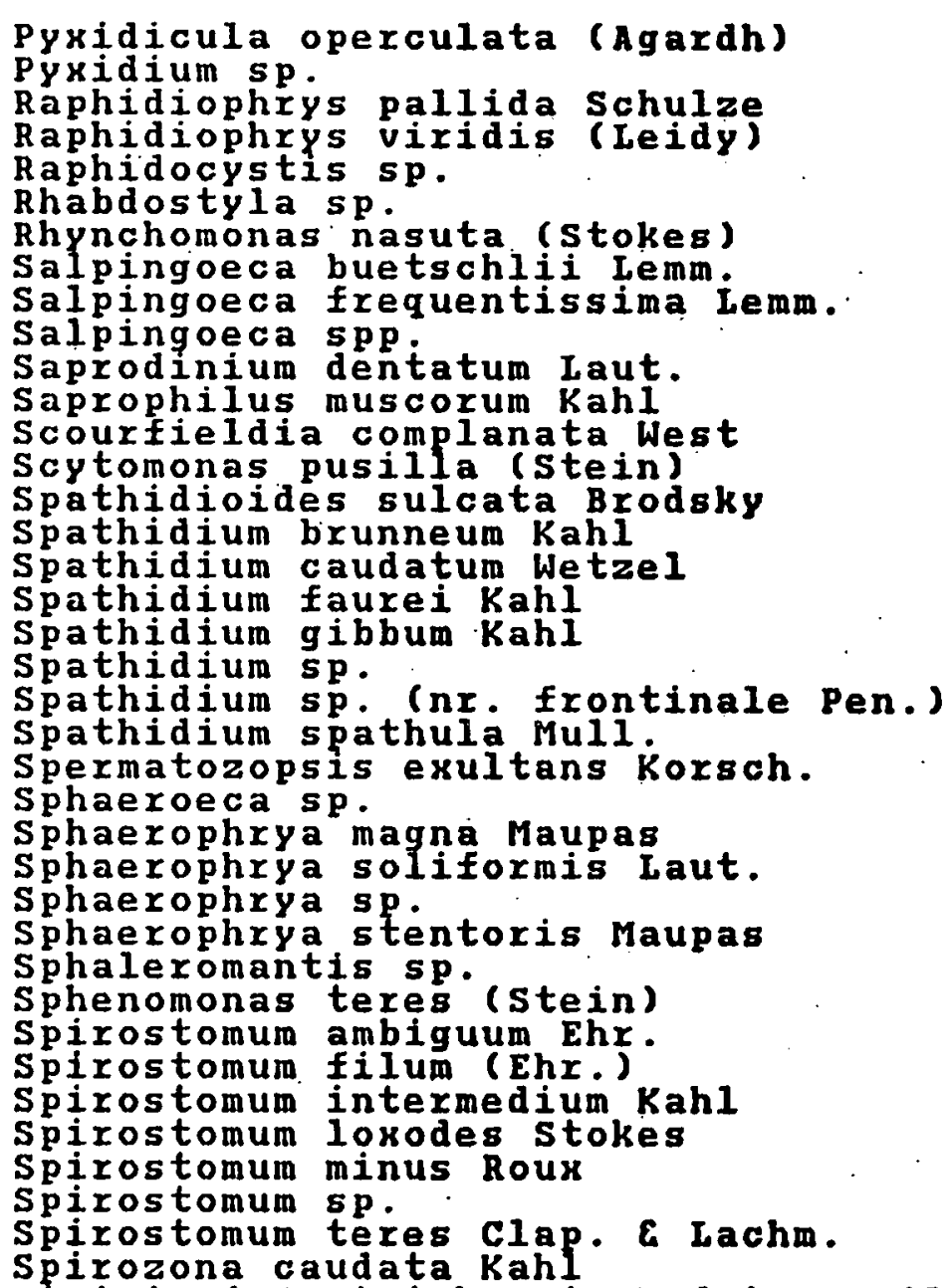




\section{APPENDIX A. SAVANKAH RIVER TAXONOMIC ACCESSION IIST}

4. PROTOZOA

NOMENCLATURE

ACCESSION NO.

GENUS \& SPECIES:

stentor amethystinus Leidy

stentor coeruleus Ehr.

Stentor igneus. Ehr.

stentor mulleri (Borg)

Stentor multiformis (Mull.)

Stentor niger (Muli.)

stentor polymorphus (Mul1.)

stentor pyriformis Johns.

Stentor roeseli Ehx.

stentor sp

Stichotricha aculeata Wrzes.

Stichotricha intermedia Froud

stichotricha secunda perty

stichotricha spp.

stokesielia sp.

strobilidium gyrans (stokes)

Strobilidium velox Faure-Fr.

Strombidium fallax (Zach.)

Strombidium spp.

strongylidium crassum sterk1

stylonychia curvata Kahl

stylonychia curvata Kahl

Stylonychia notophora stokes

stylonychia pustulata (Ehr.)

stylonychia putrina stokes

stylonychia sp

stylopyris mucicola Bolochonzew

Syncrypta sp

Synura adamsi smith

Synura uvella Ehr.

Tetrahymena geleii Furg.

Tetrahymena patula (Ehr.)

Tetrahymena pyriformis ehr.

Tetrahymena sp.

Tetrahymena vorax (Kid., Iilly \& Claff)

Tetramitus rostratus perty

Thurcicola folliculata (Mull.)

Thylacidium truncatum sches.

1415

1417

1418

1419

1420

1421

1486

1487

1488

1489

857

1425

1426

1424

1490

1491

1492

1493

1494

1495

1496

858

860

861

861
1497

1387

1388

1389

1391

13907

1530

1395 
APPENDIX A. SAVAKMAG RIVER TAXOKOMIC ACCESSIOK LIST

4. PROTOZOA

YOMENCLATURE

ACCESSIOK NO.

GENUS \& SPECIES:

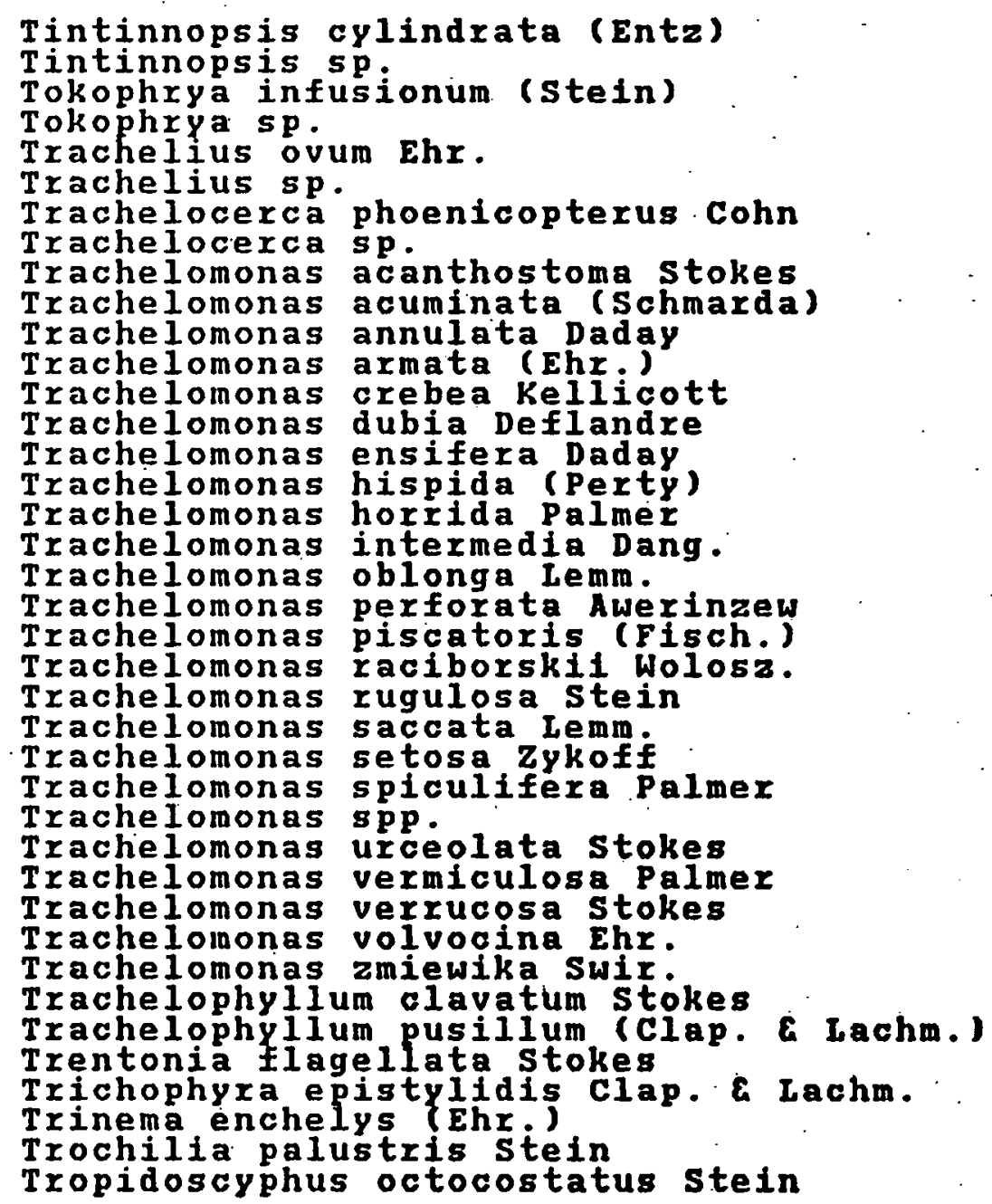


APPENDIX A. SAVAKKAH RIVER TAXONOMIC ACCESSION LIST

4. PROTOZOA

MOMENCLATURE

ACCESSION NO.

GENUS \& SPECIES:

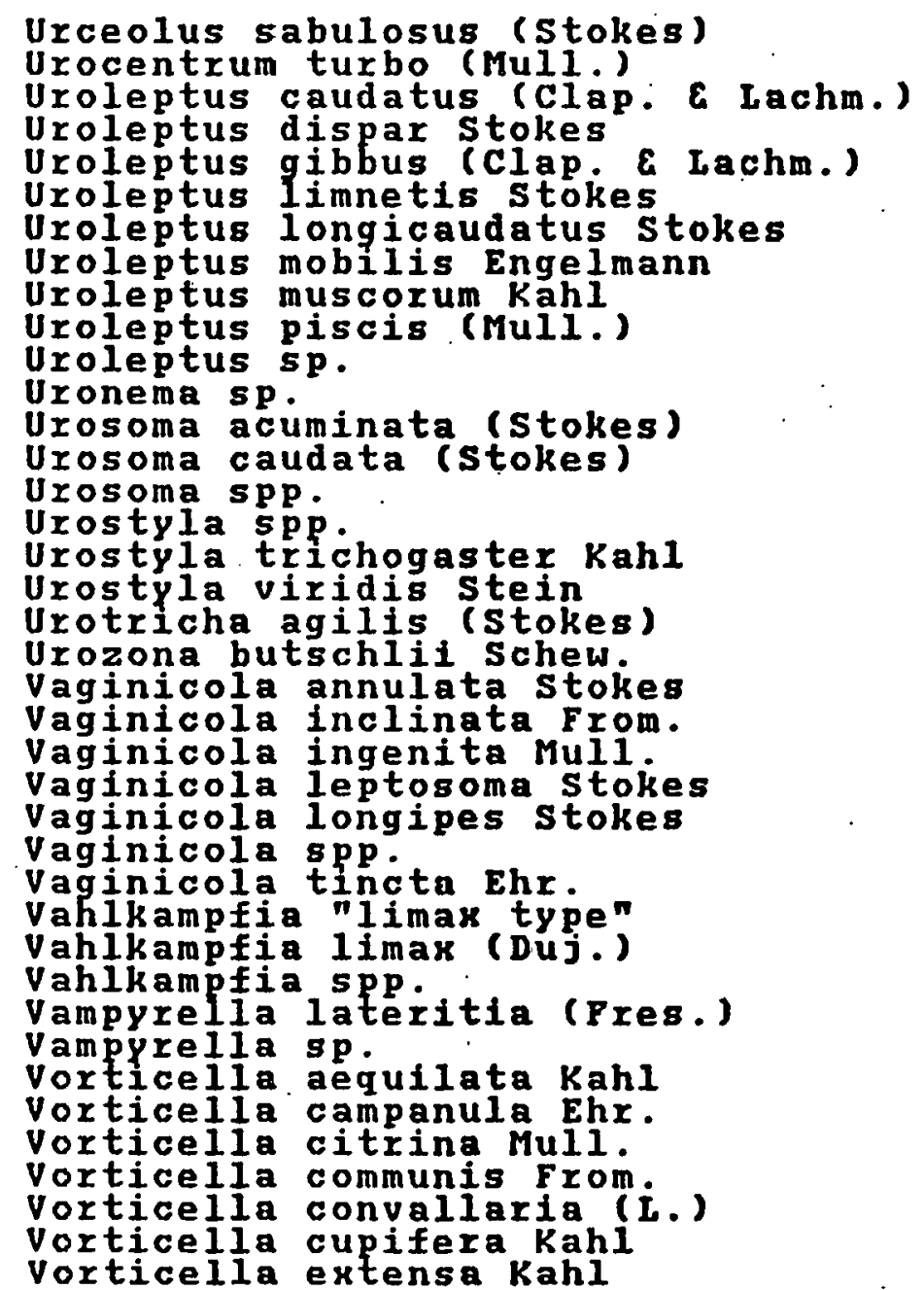


APPEUDIX A. SAVAMKAH RIVER TAXOMOMIC ACCESSIOK LIST

4:" PROTOZOA

NOMEKCLATURE

ACCESSIOH NO.

GENUS \& SPECIES:

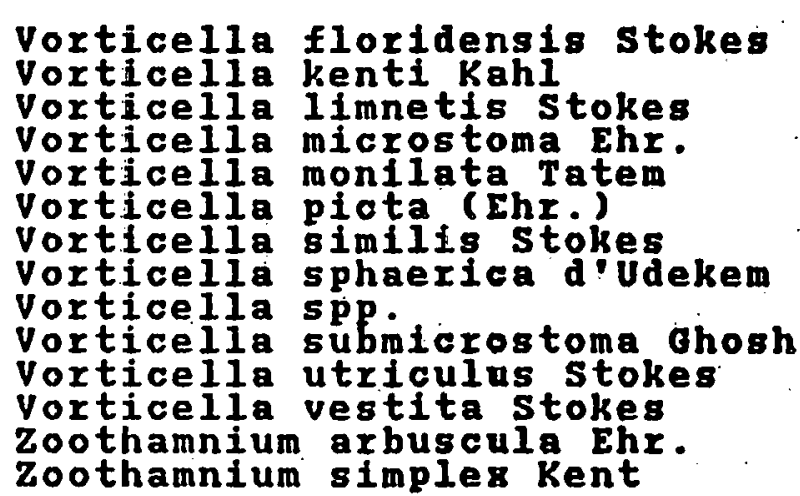

1546

1547

1548

1549

1550

1551

1552

1557

1554

1555

1556

1558

Zoothamnium arbuscula Ehr. 
Appendix A. Savannah River Taxonomic Accession List

V. Unidentified Taxa*

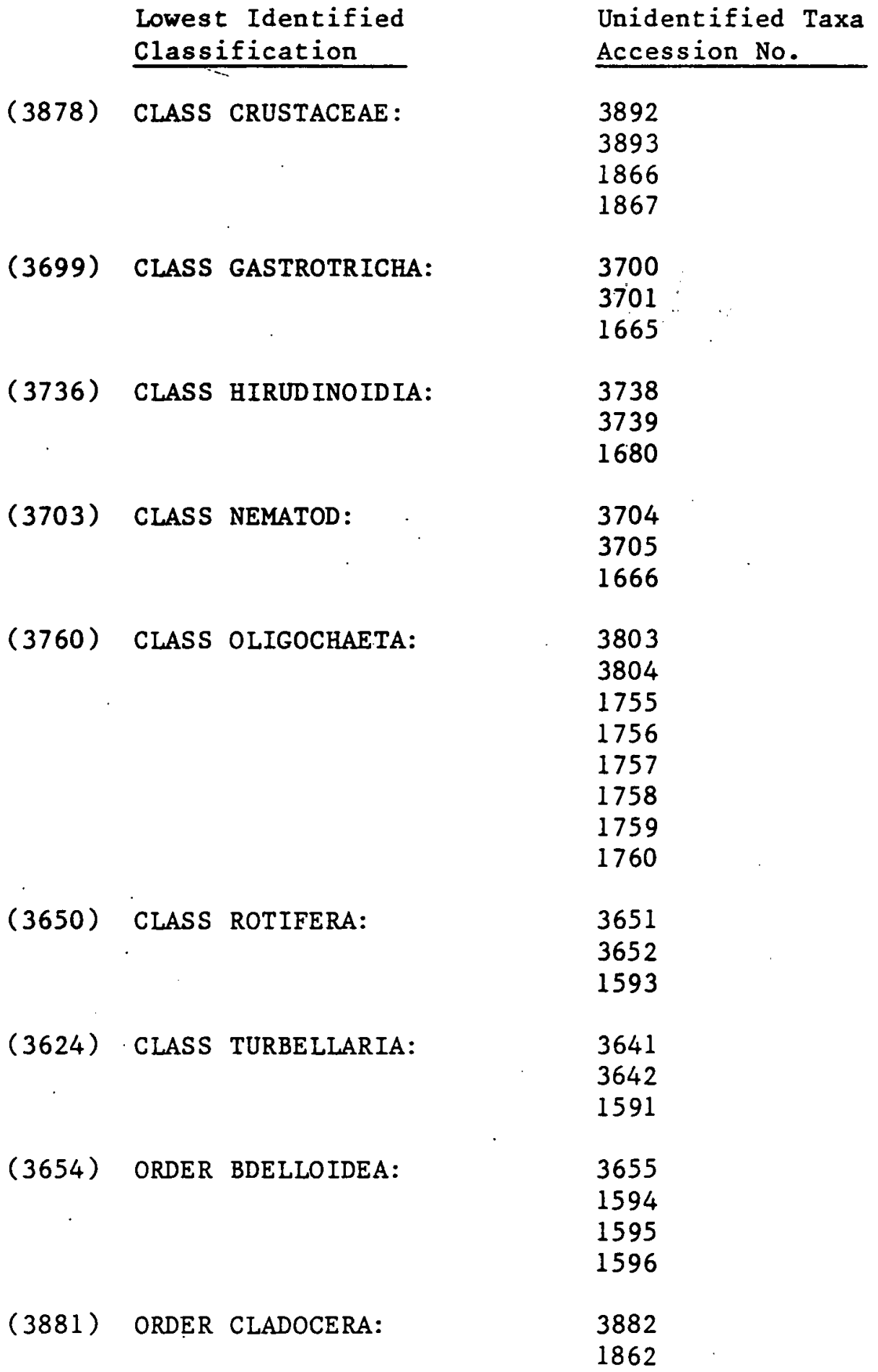

* All taxa are in macroinvertebrate subgroup. 


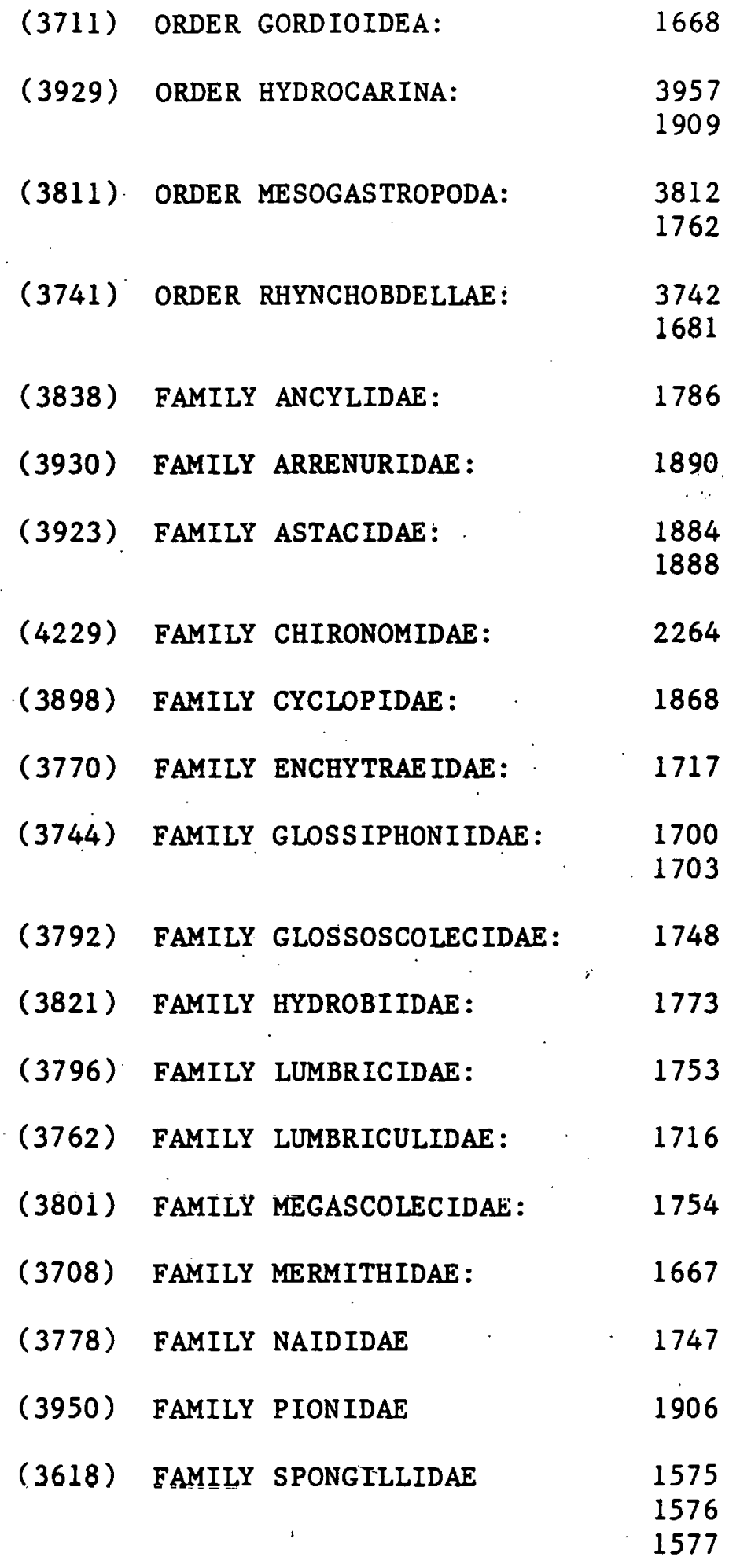


Appendix B. Sample Data Presentations

B.1 Savannah River Taxonomic Data Summary.

B.2 Sample Presence/Absence Data for Two Diatom Species.

B.3 Sample Diatometer Data.

B.4 Savannah River Water Chemistry Summary. 


\section{B.1. Savannah River Taxonomic Data}

Taxonomic data from all 16 major river surveys have been summarized in Figures B.1.1-B.1.36. These data have been condensed into major taxonomic subgroups and graphed to show general trends over time at each survey station. 
HIn 


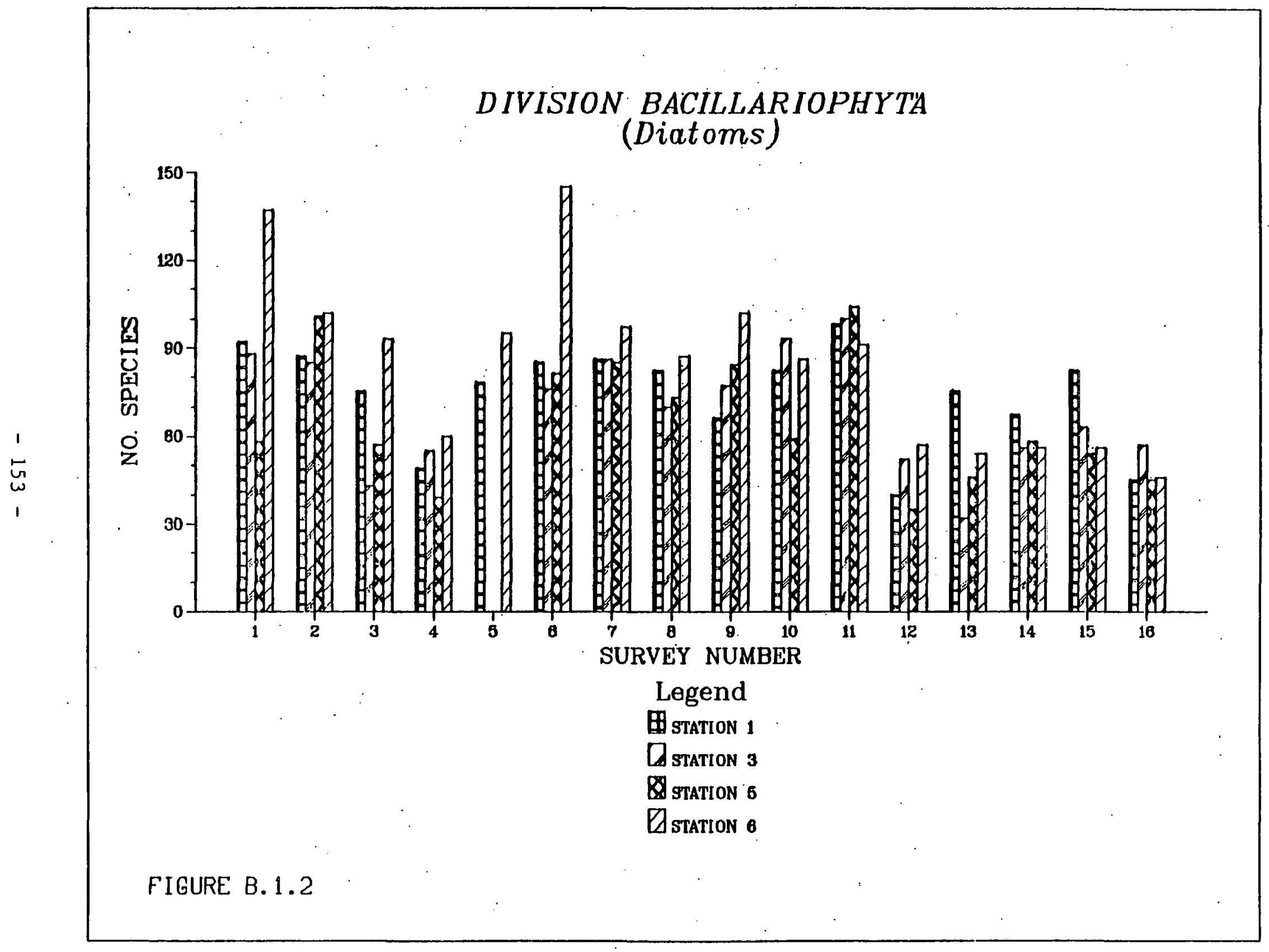




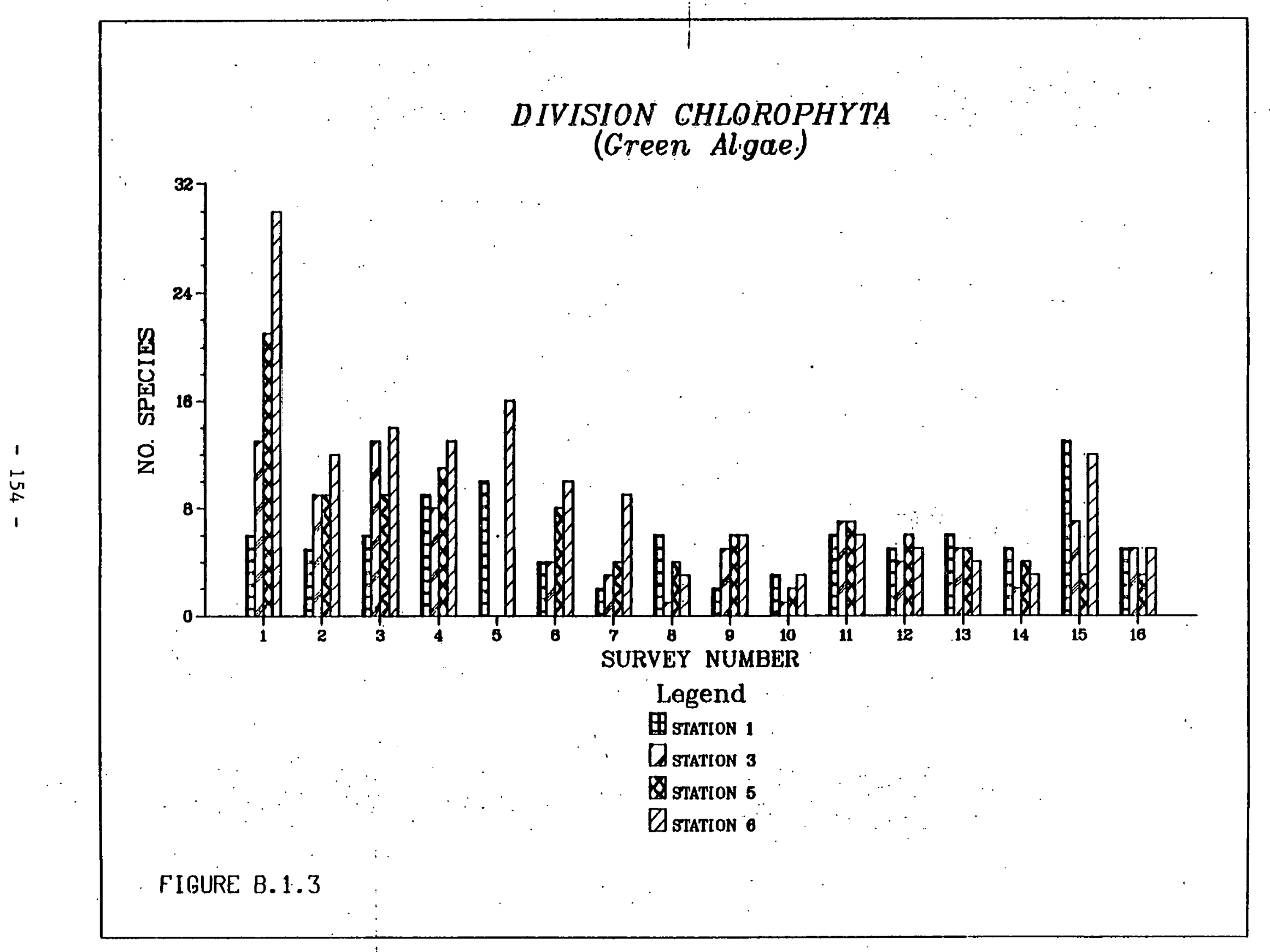




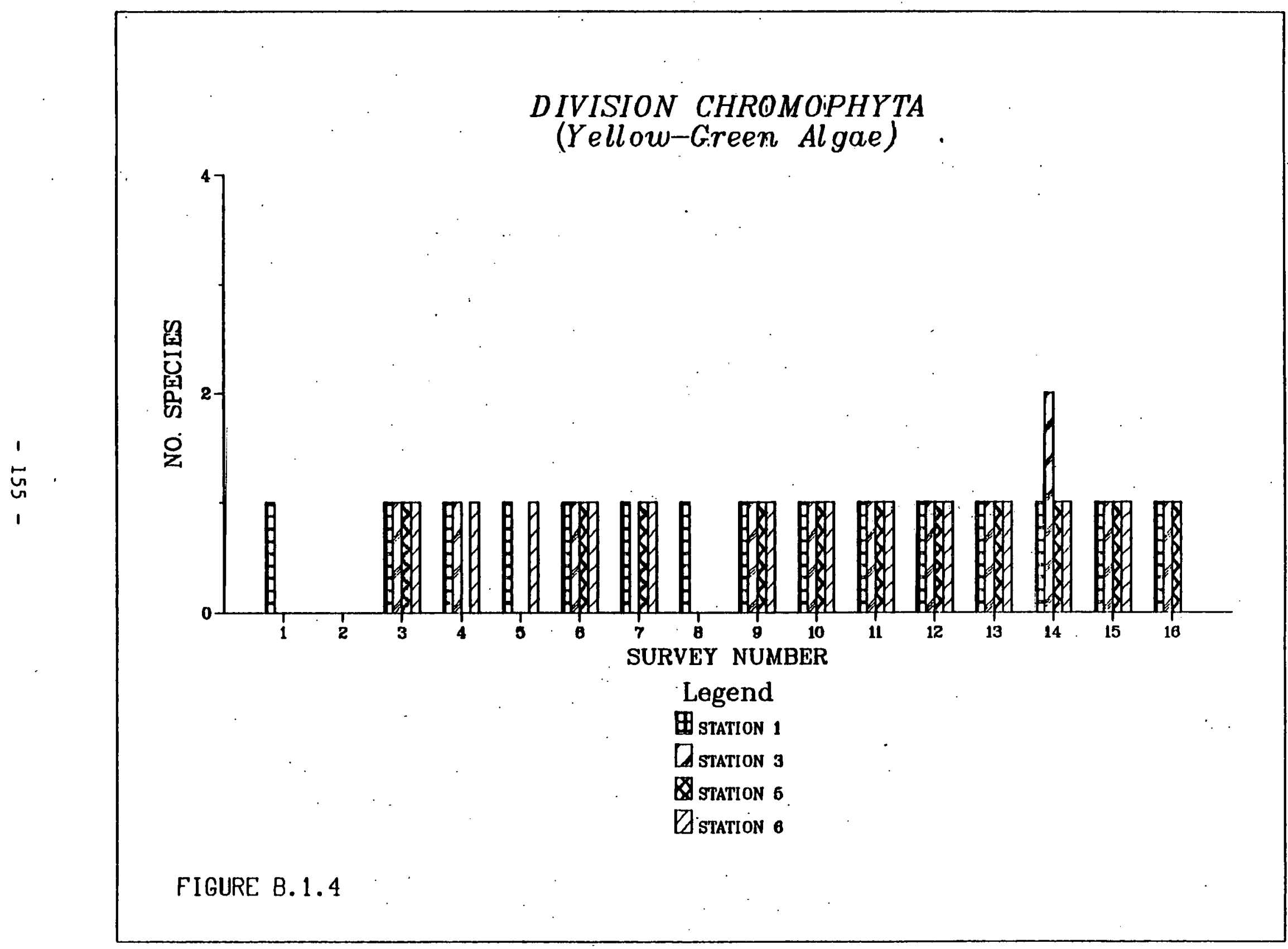




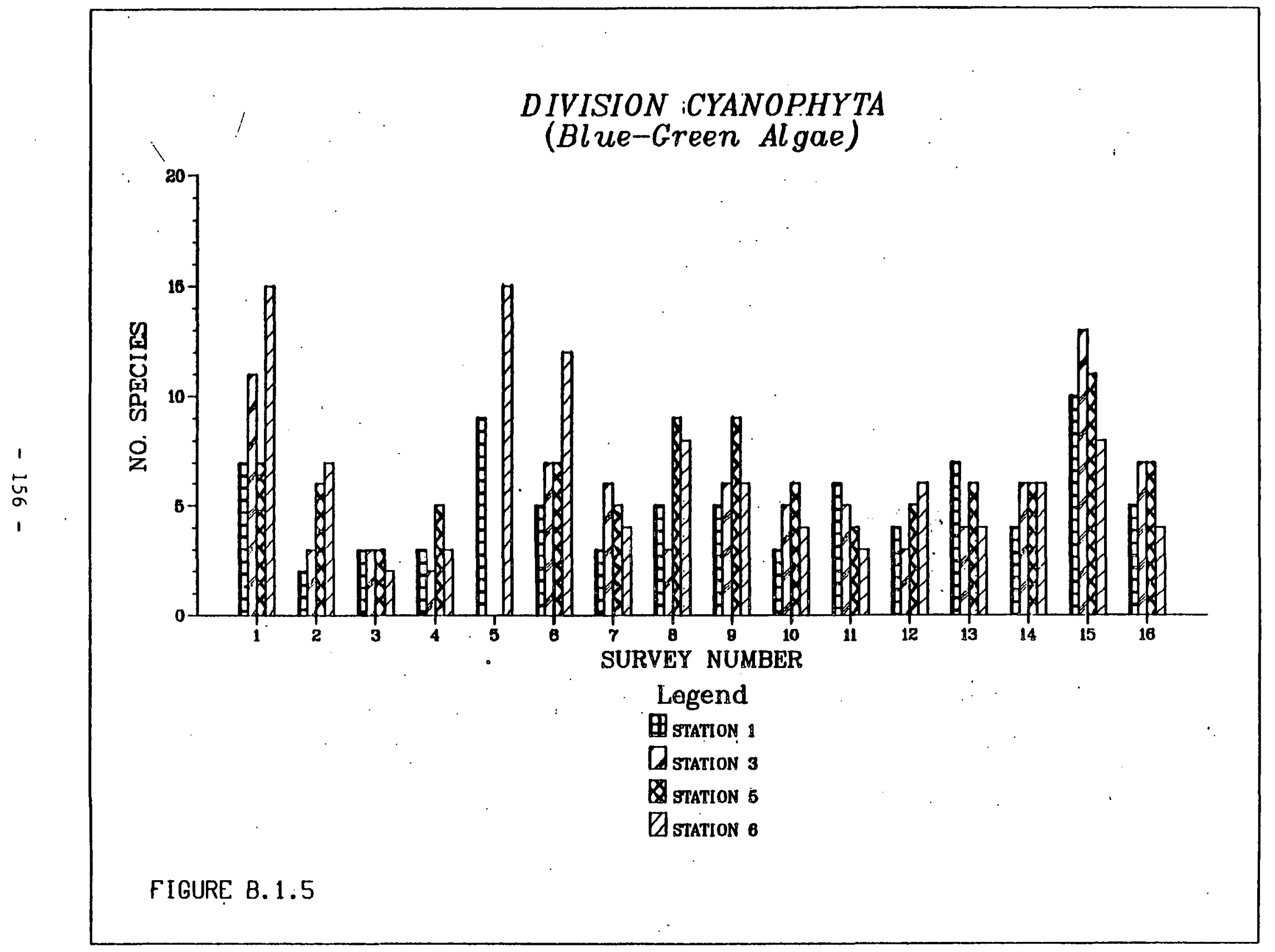




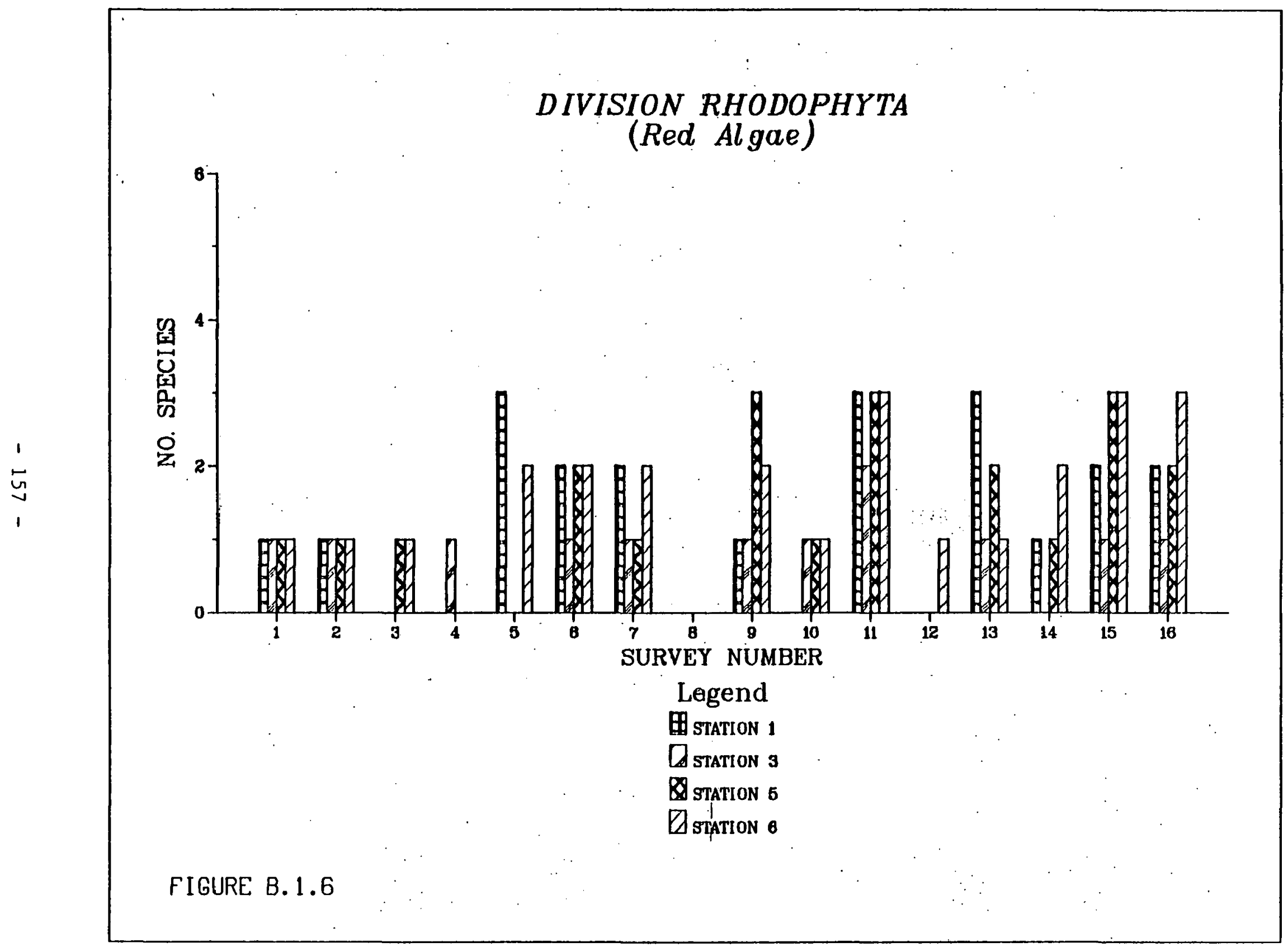




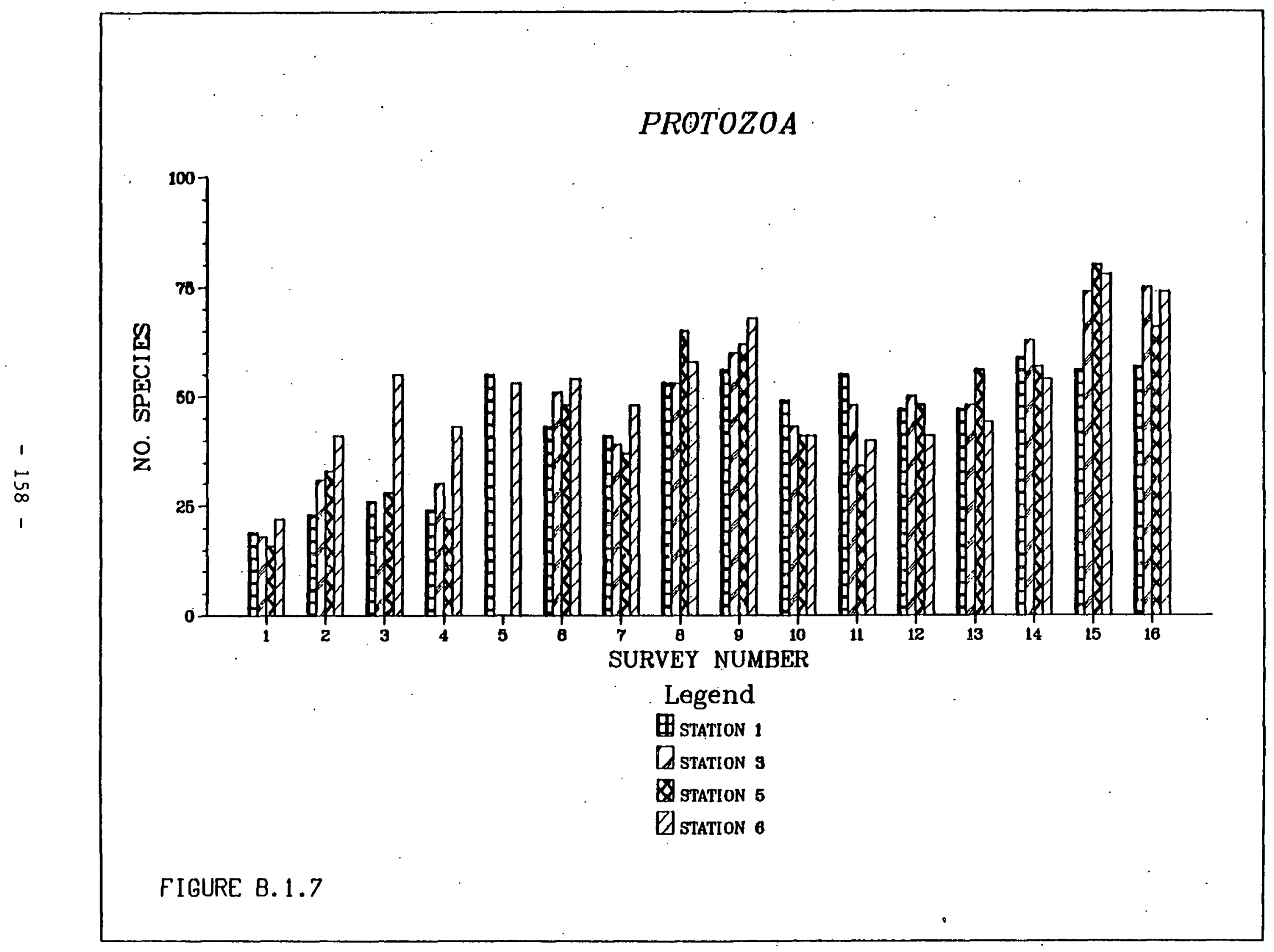




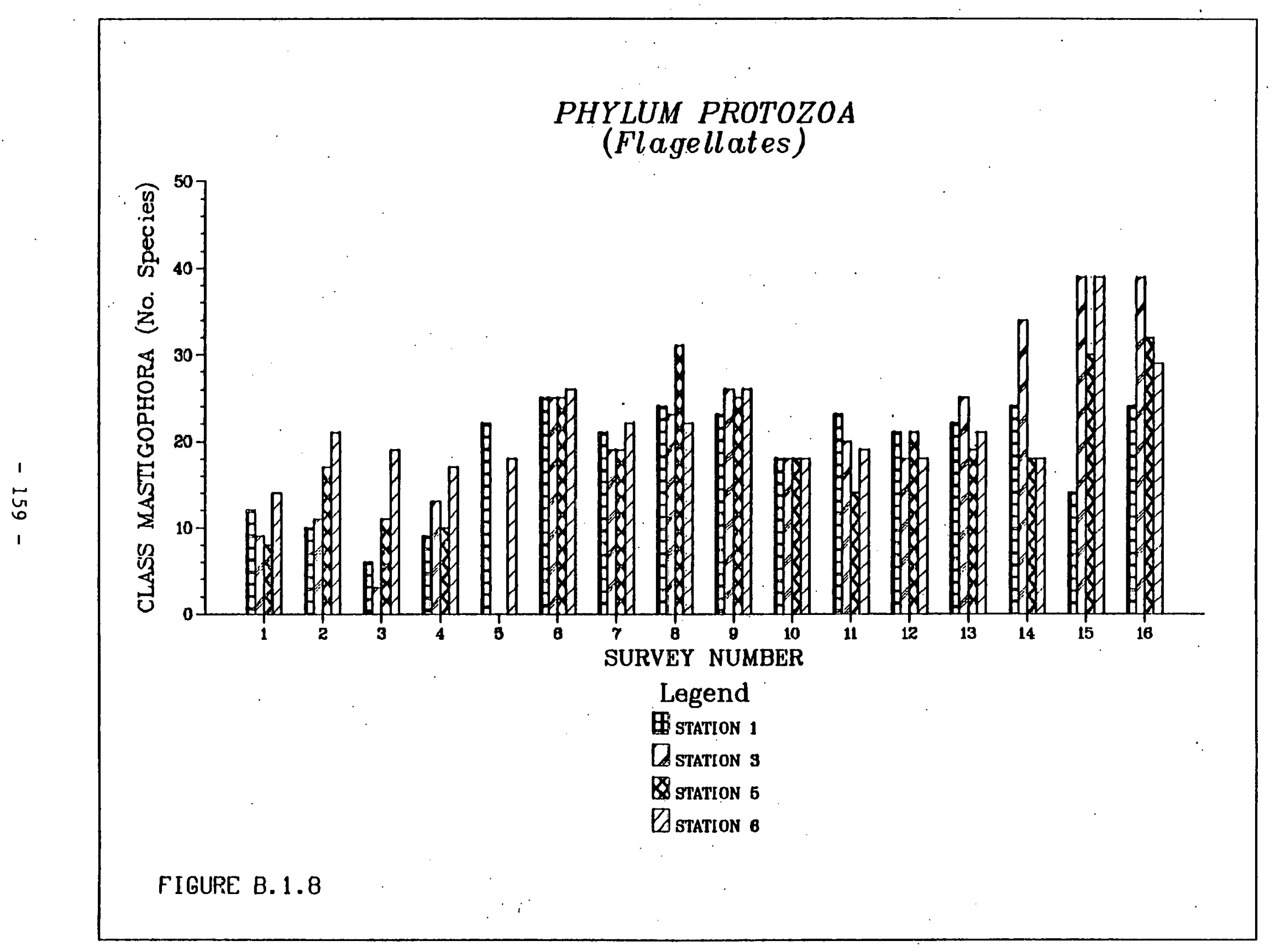




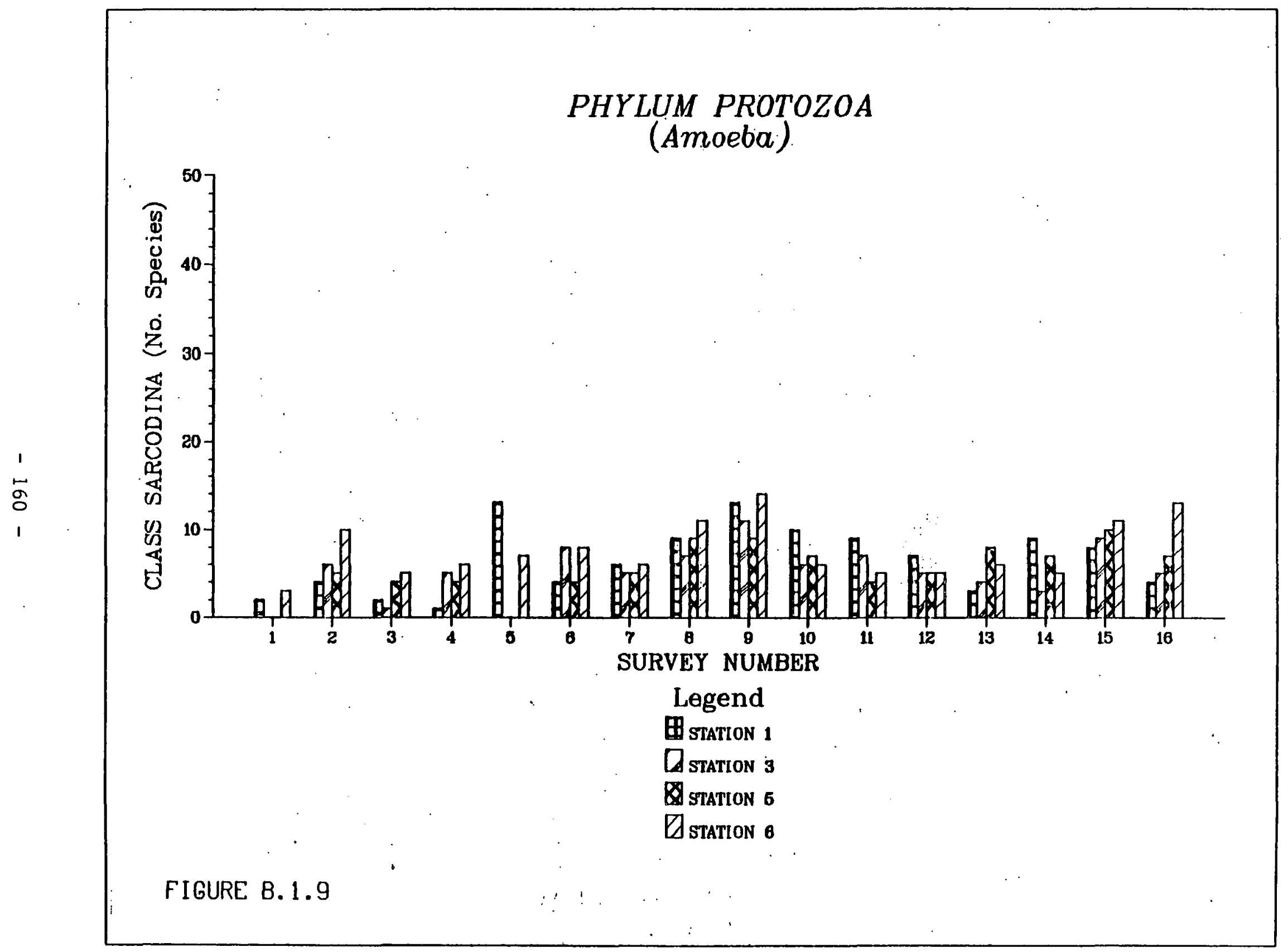




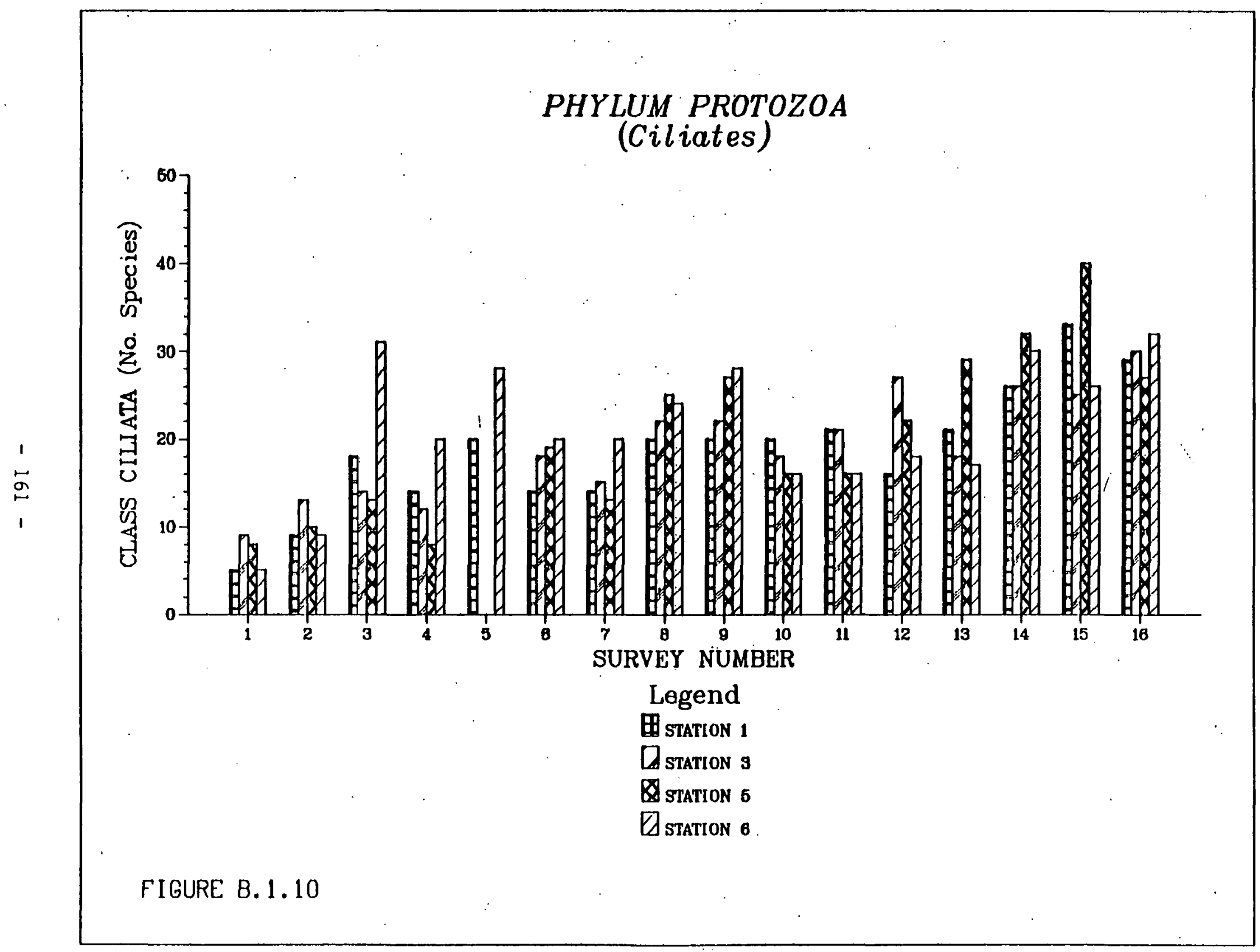




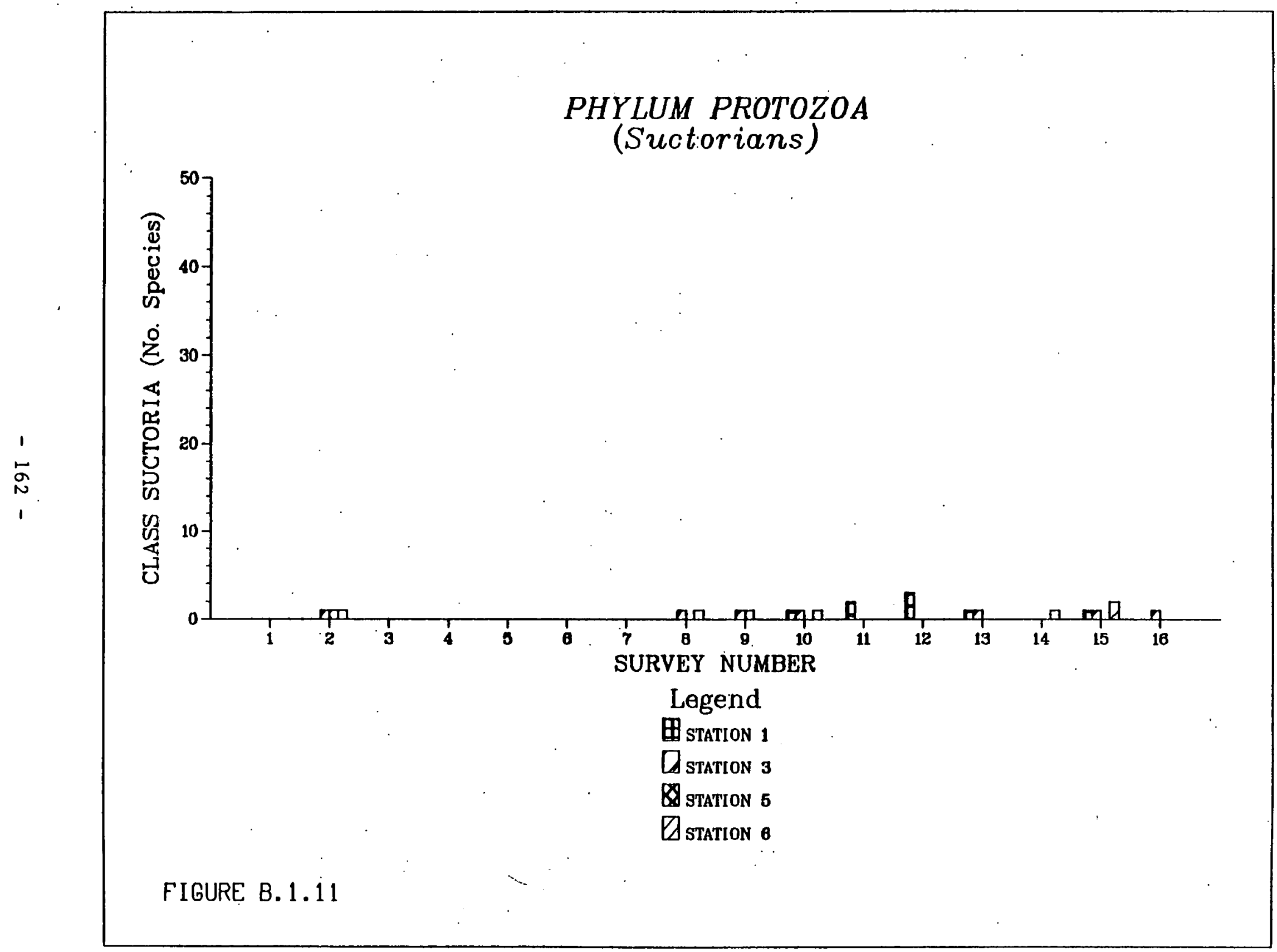




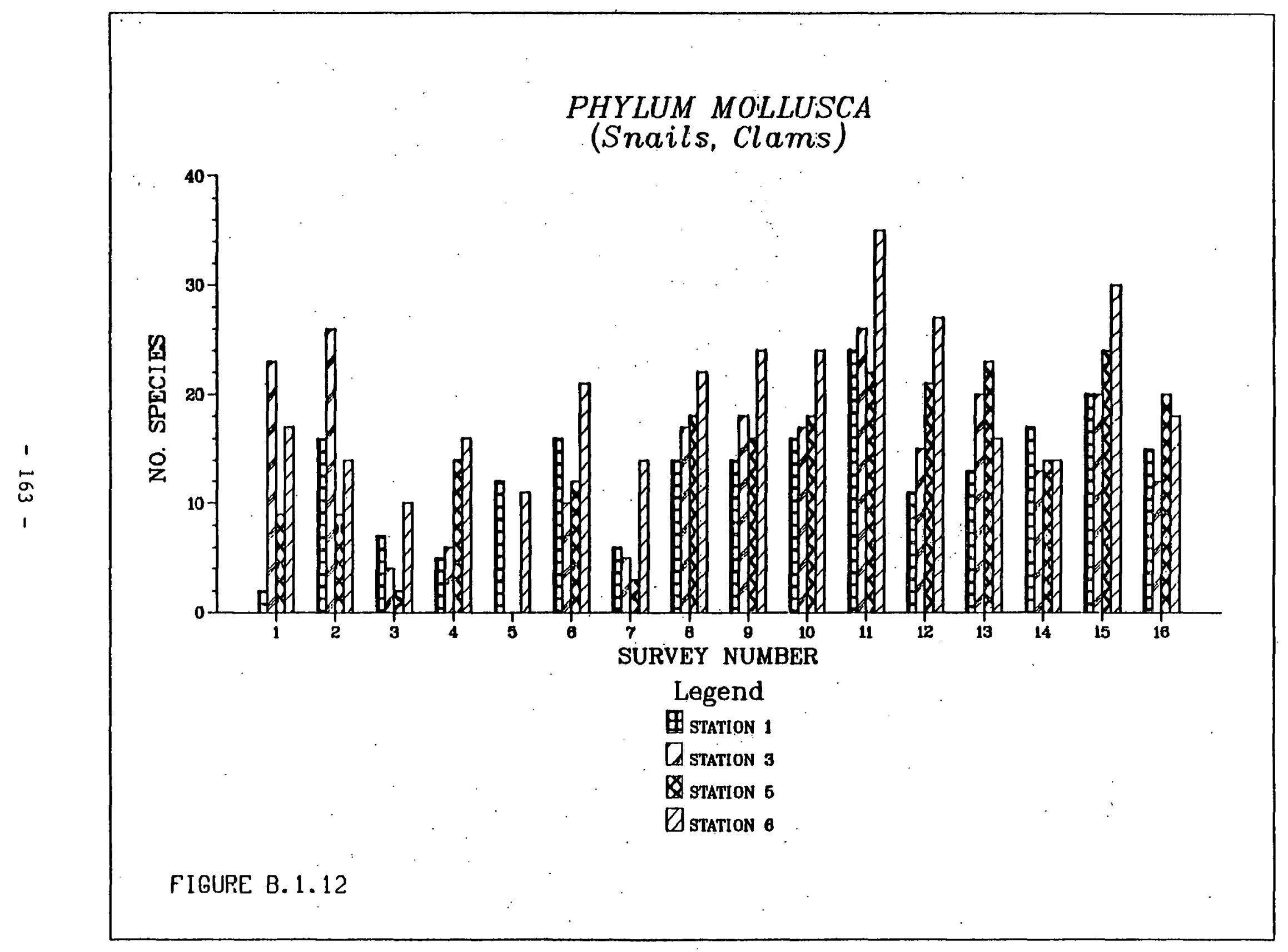




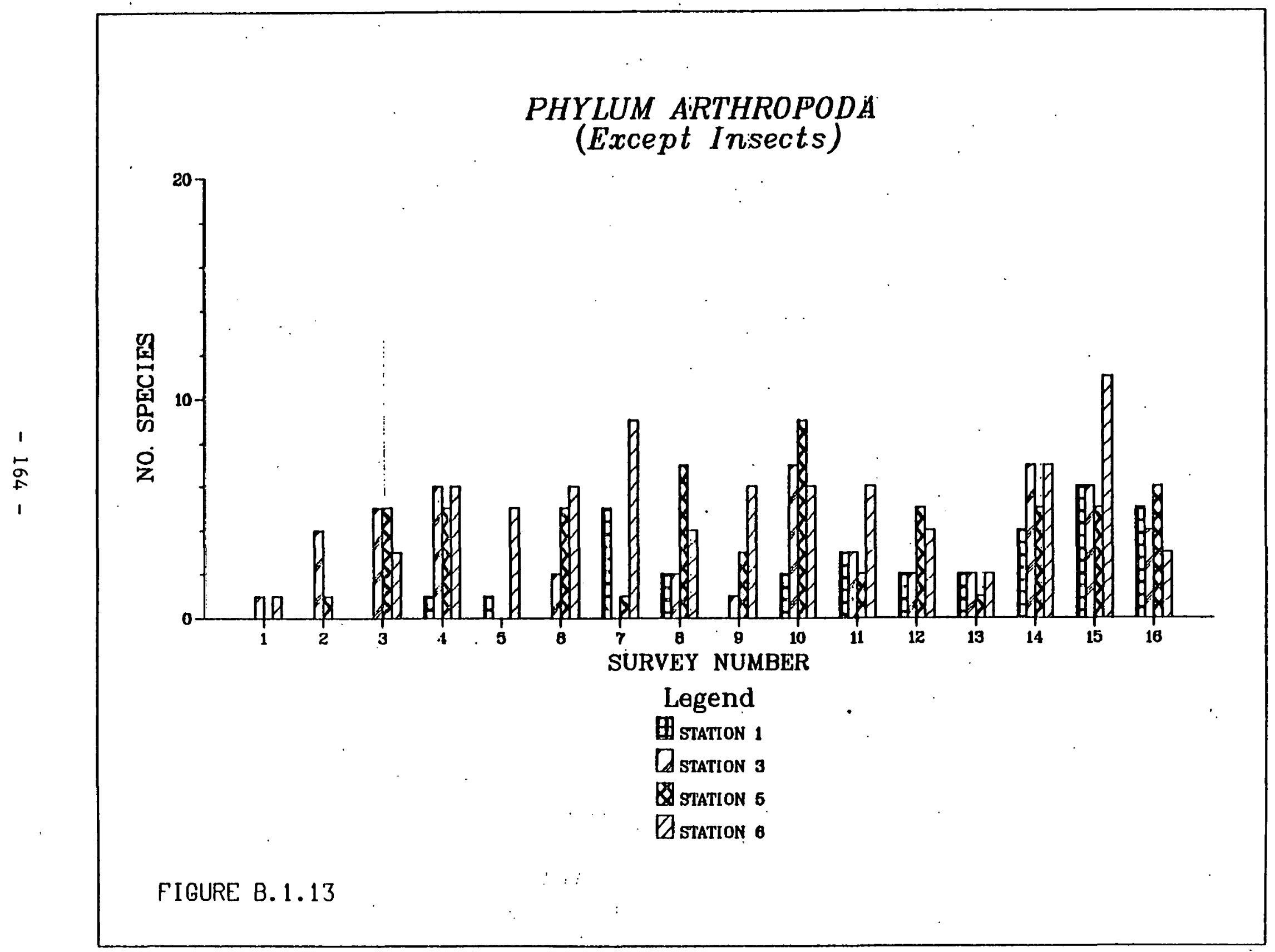




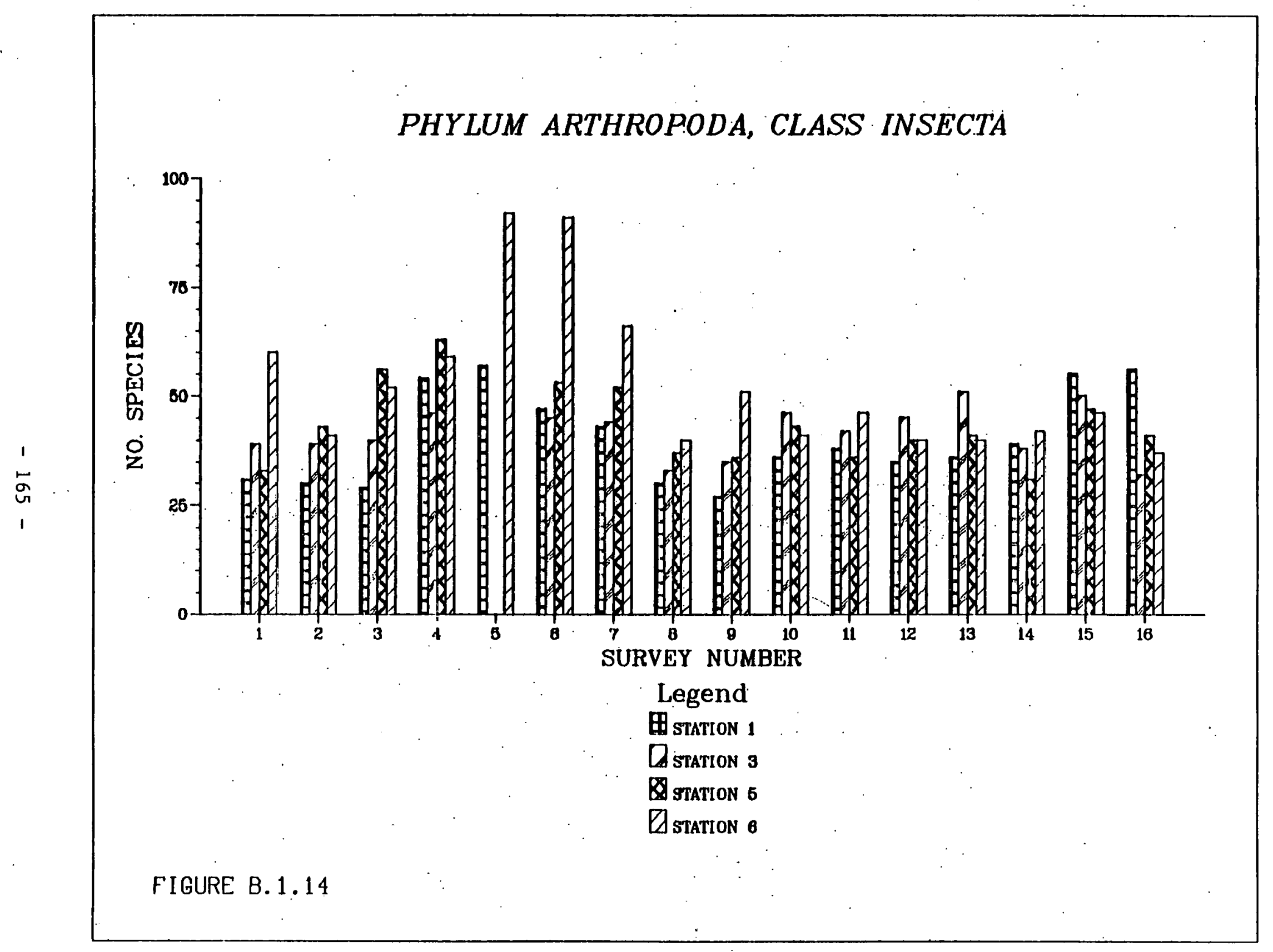


PHYLUM ARTHROPOD, CLASS INSECT

(Dragon Flies)

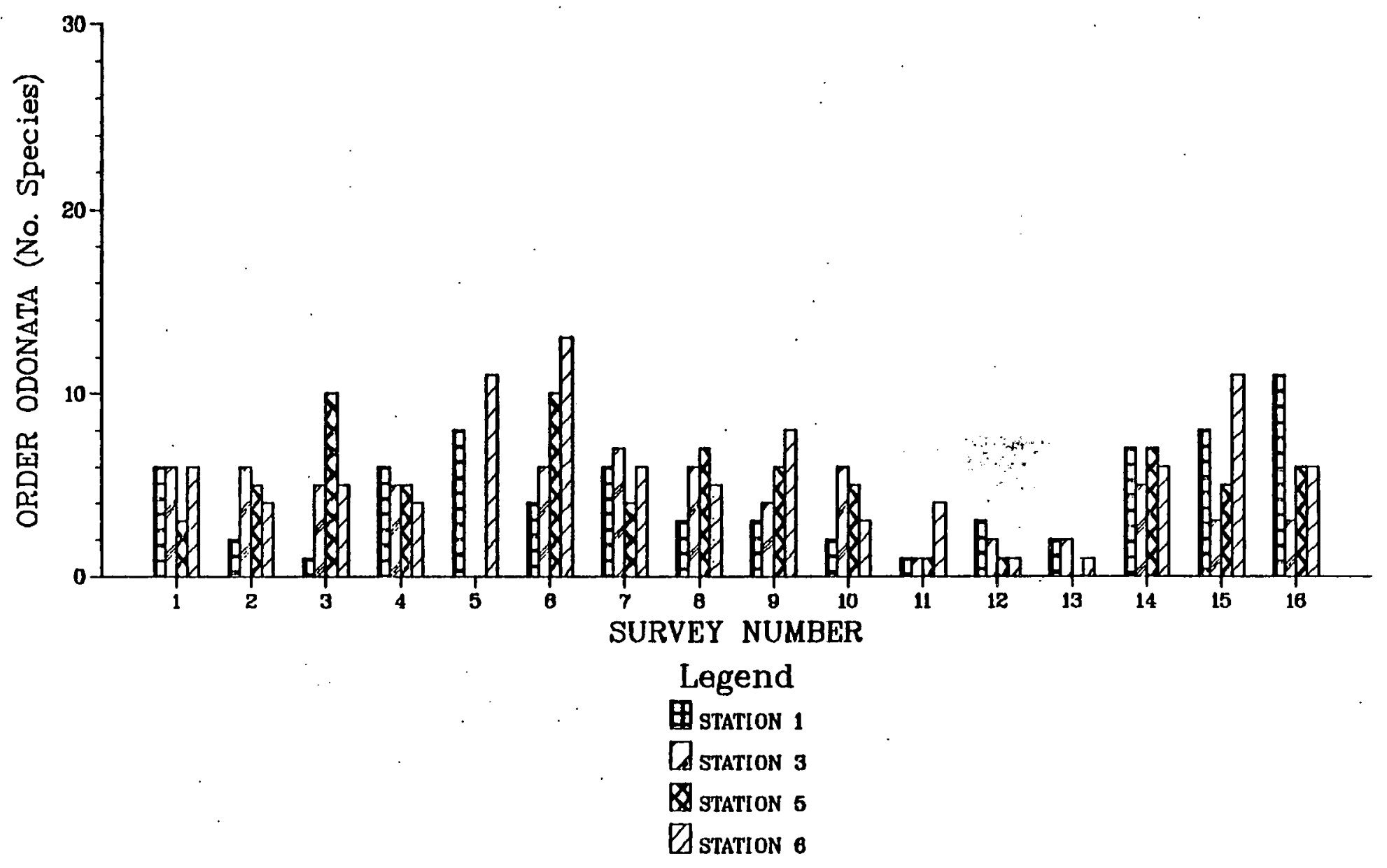

FIGURE B. 1.15 
PHYLUM ARTHROPODS, CLASS INSECTS
(Mayflies)

.

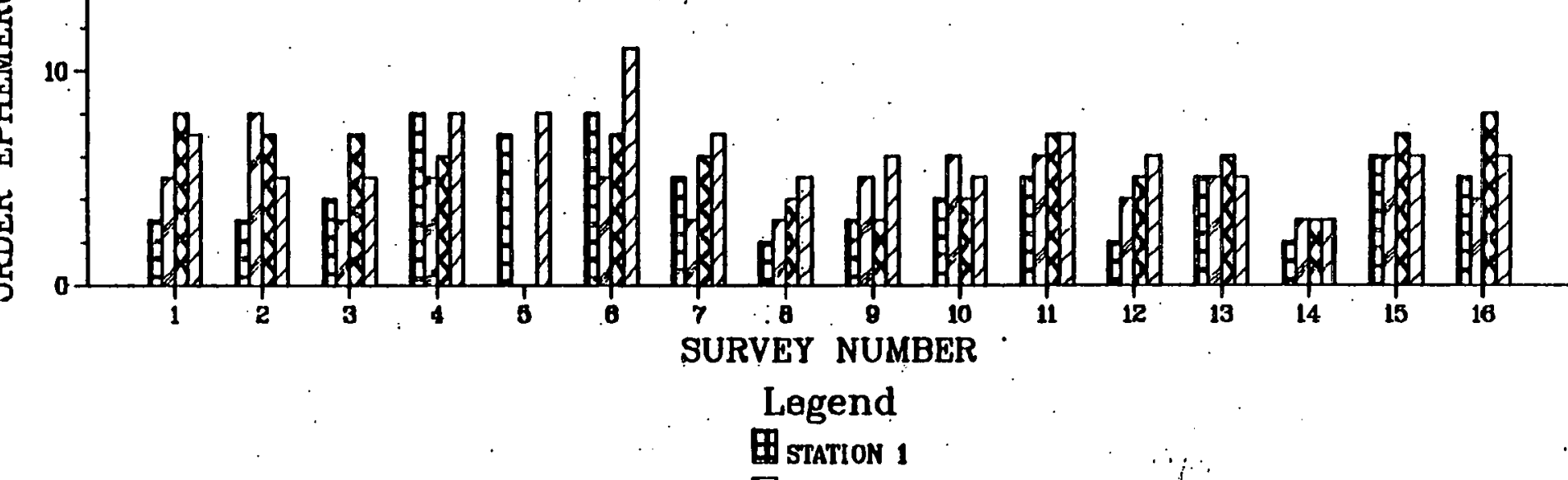




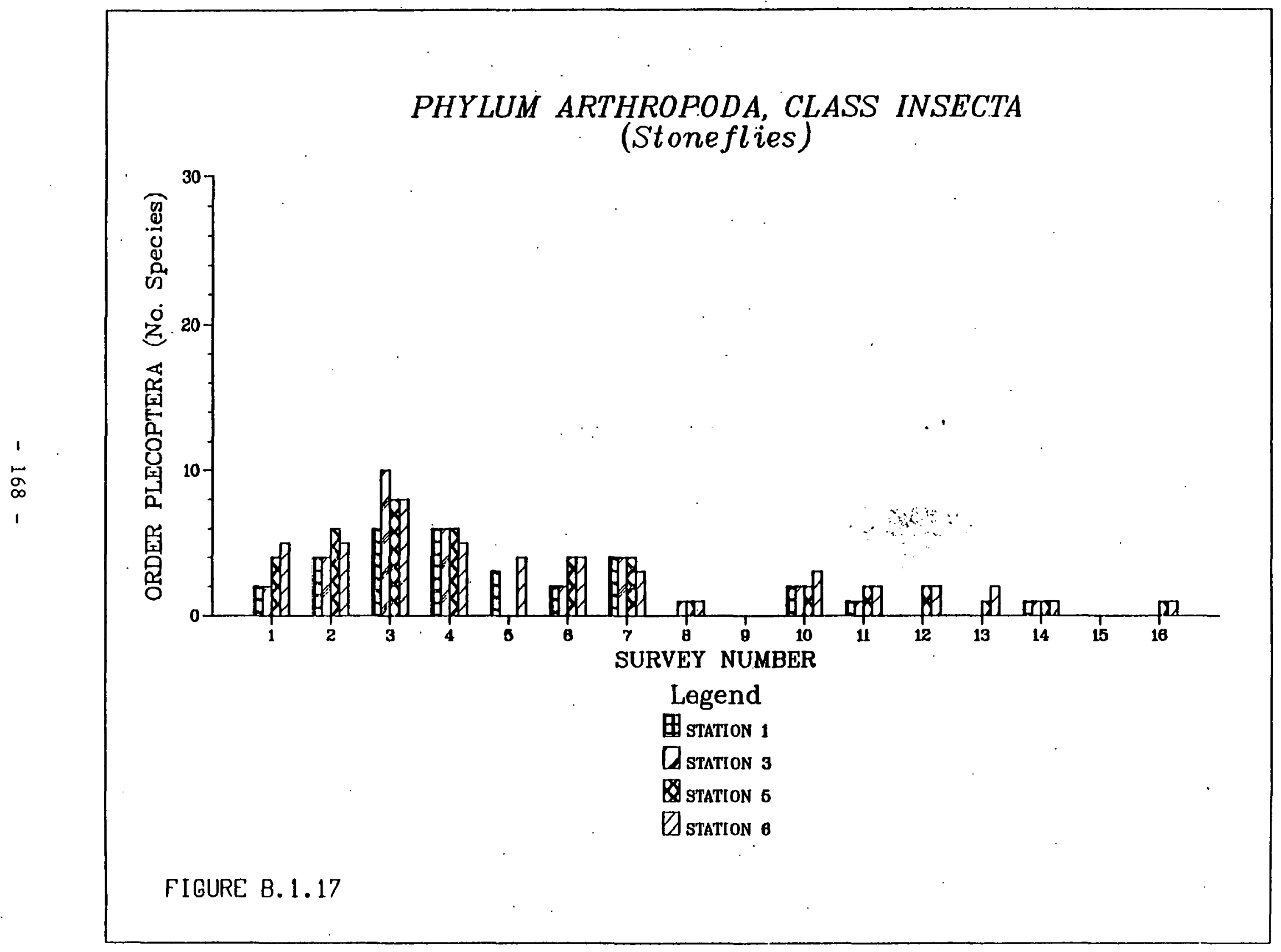




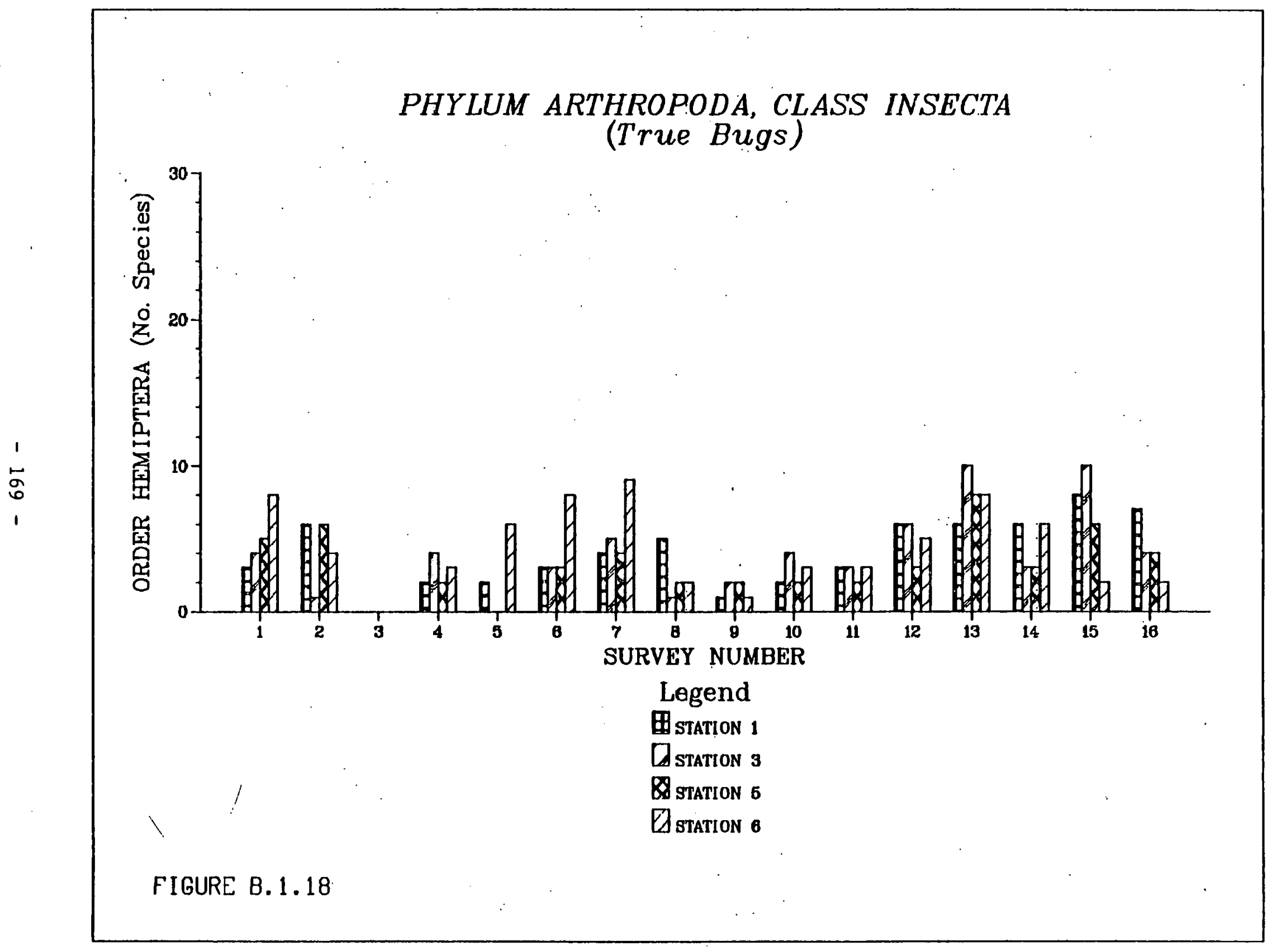




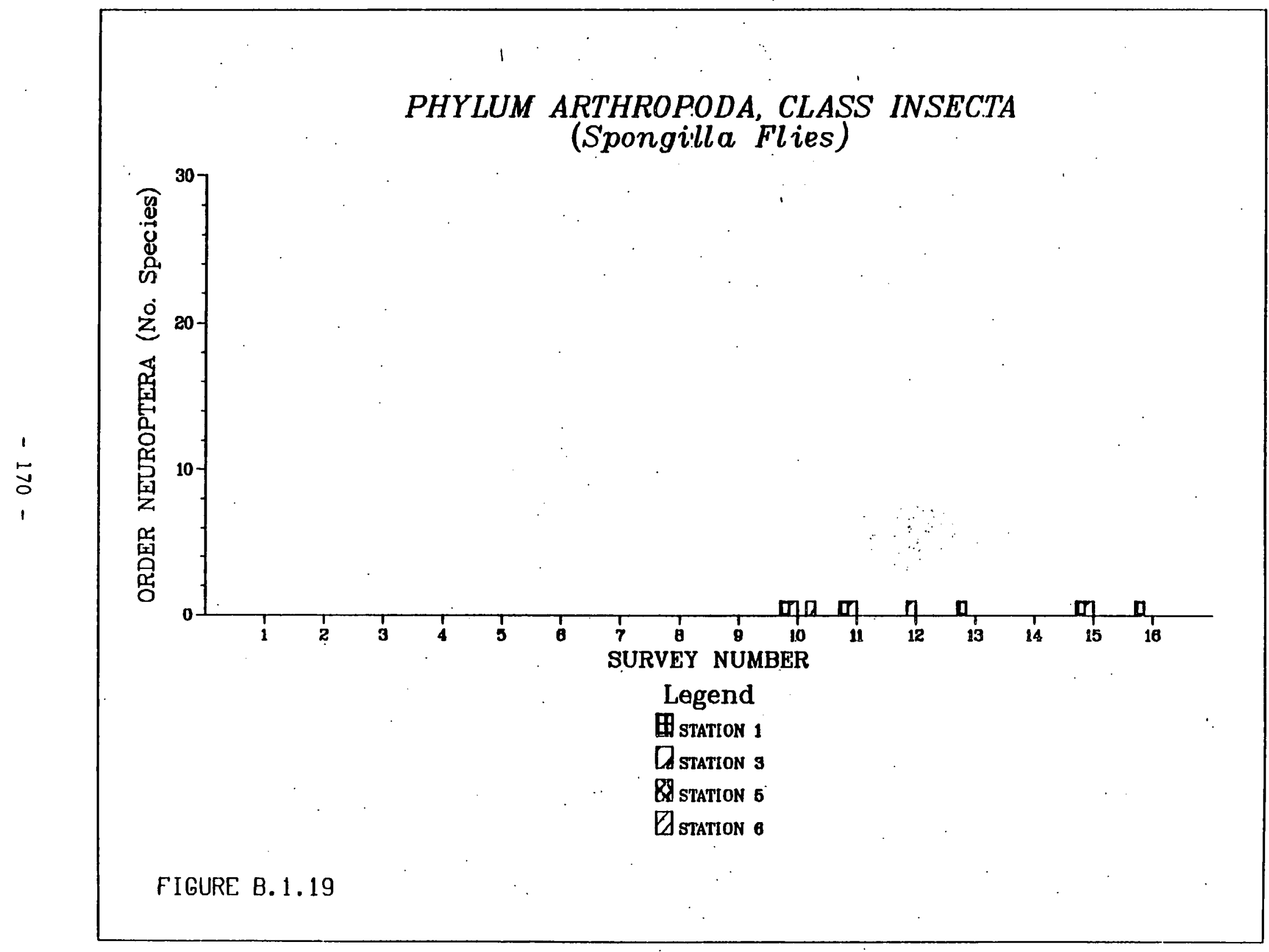




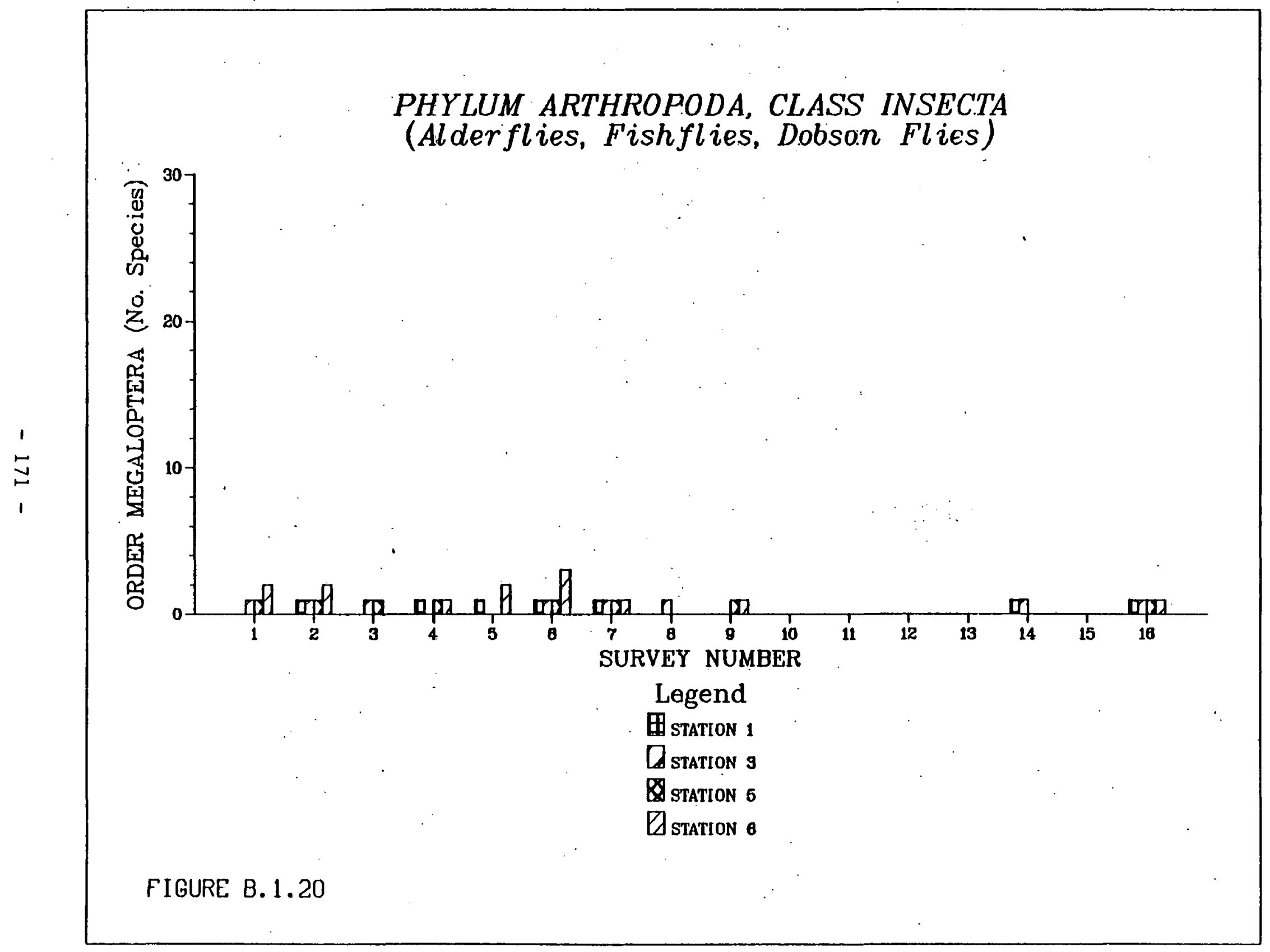




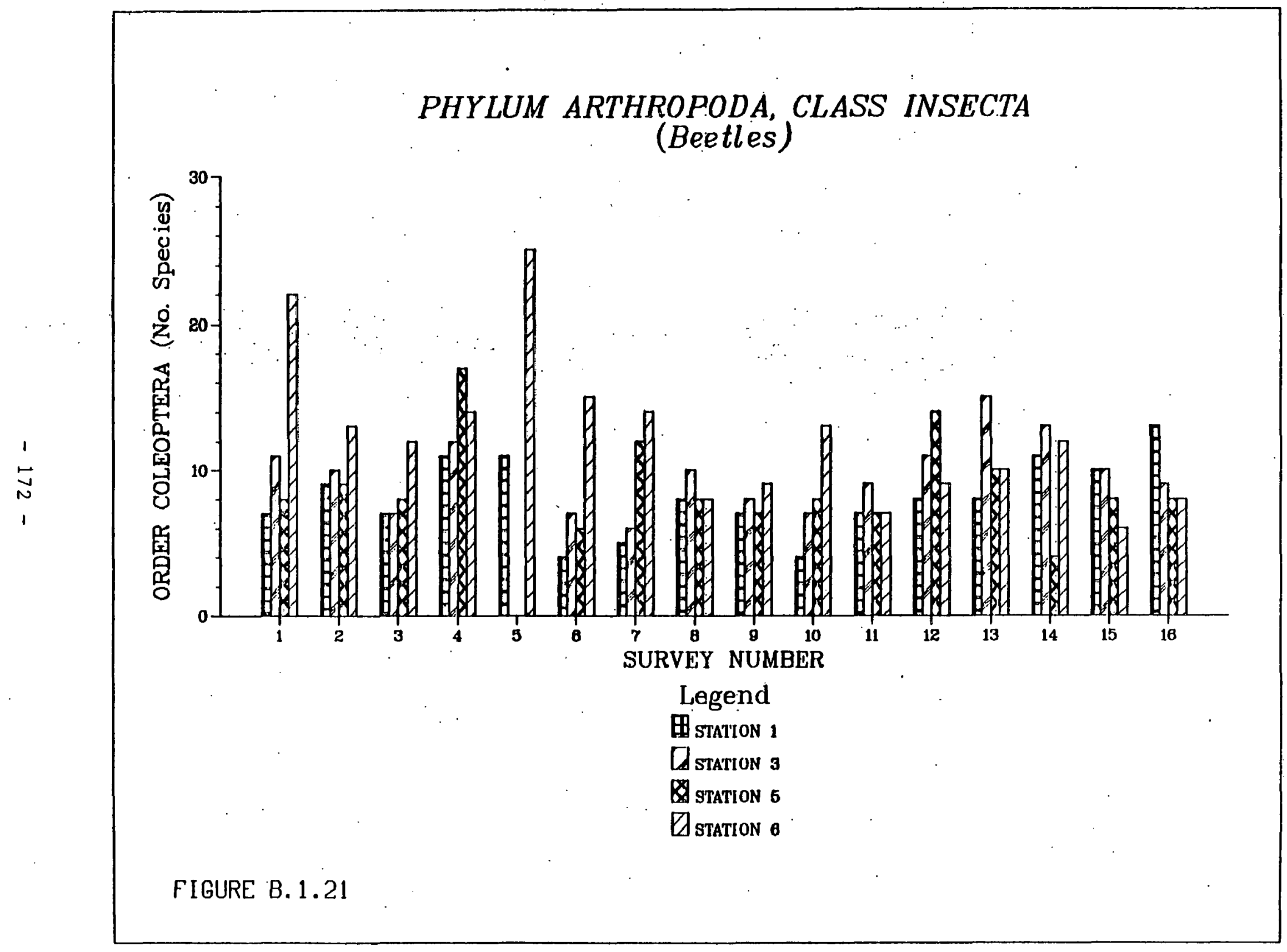




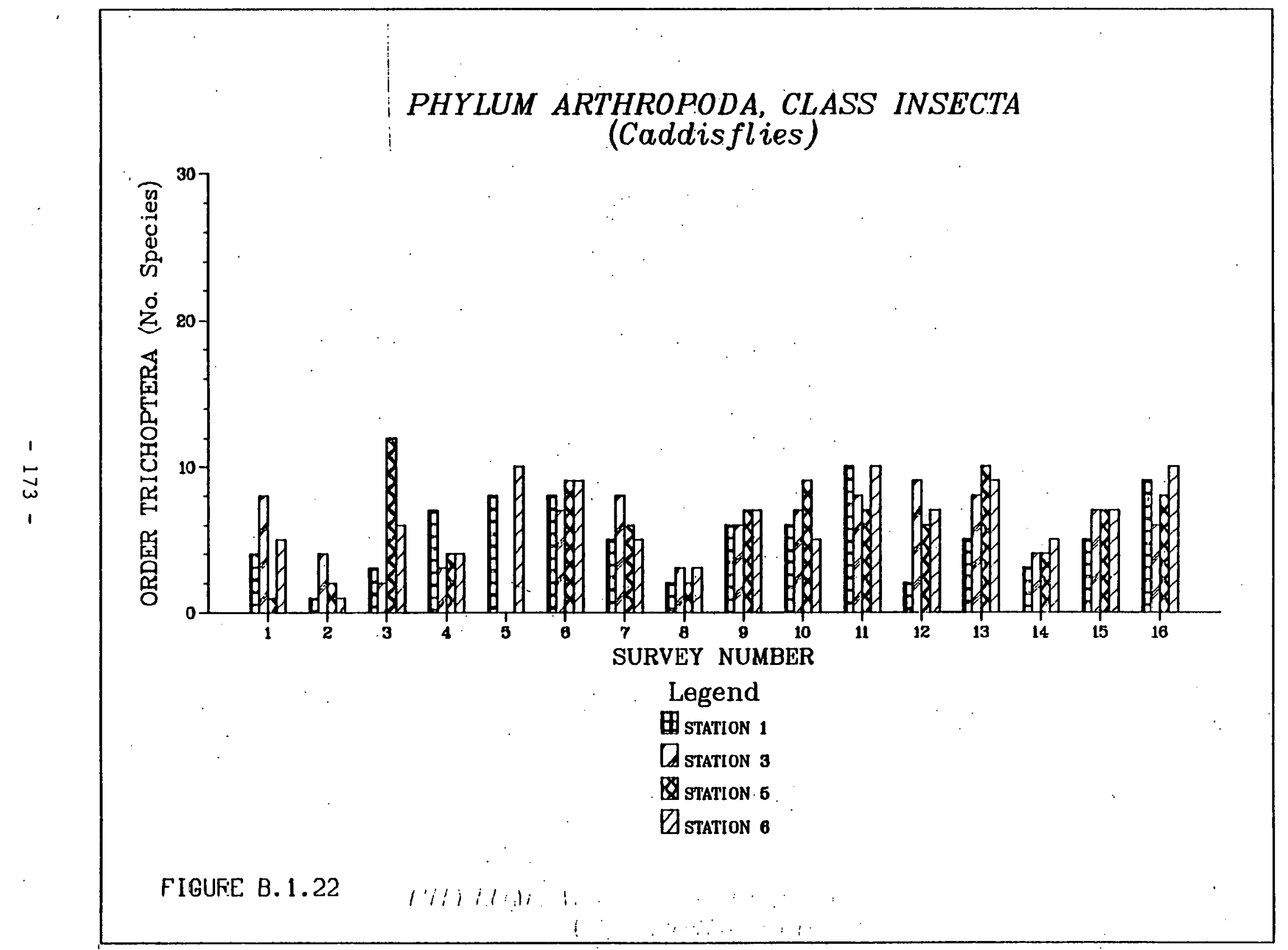




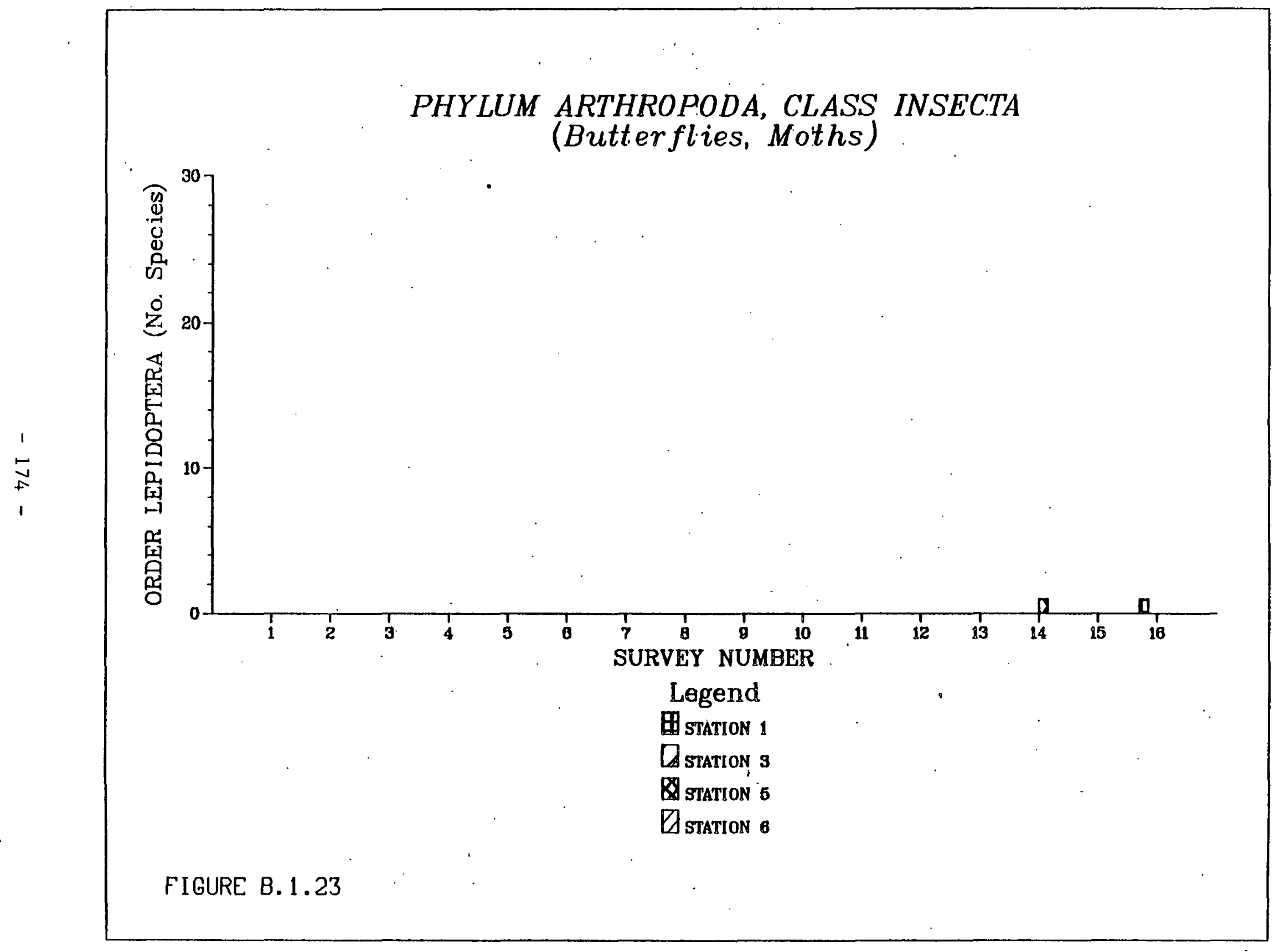




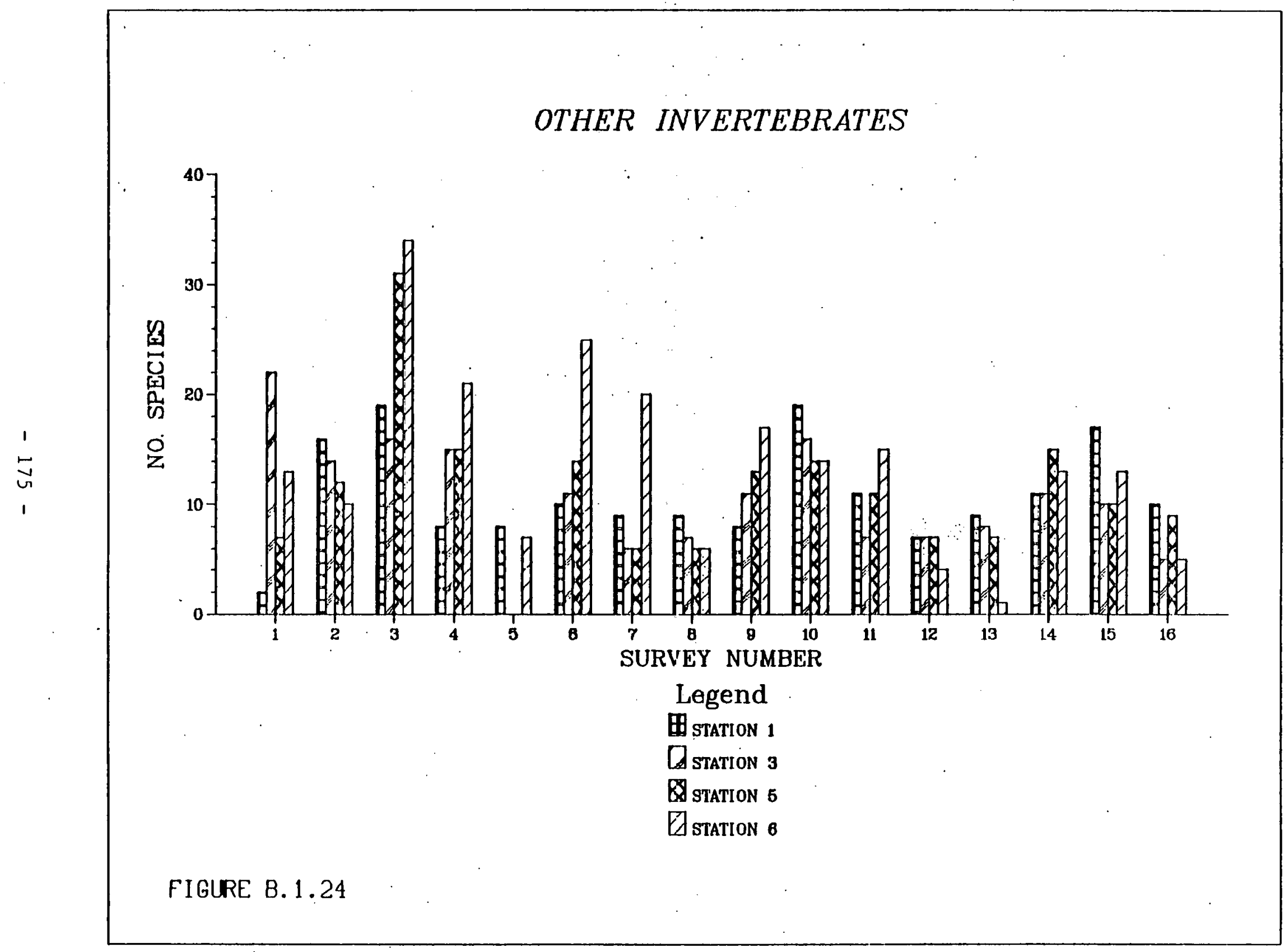




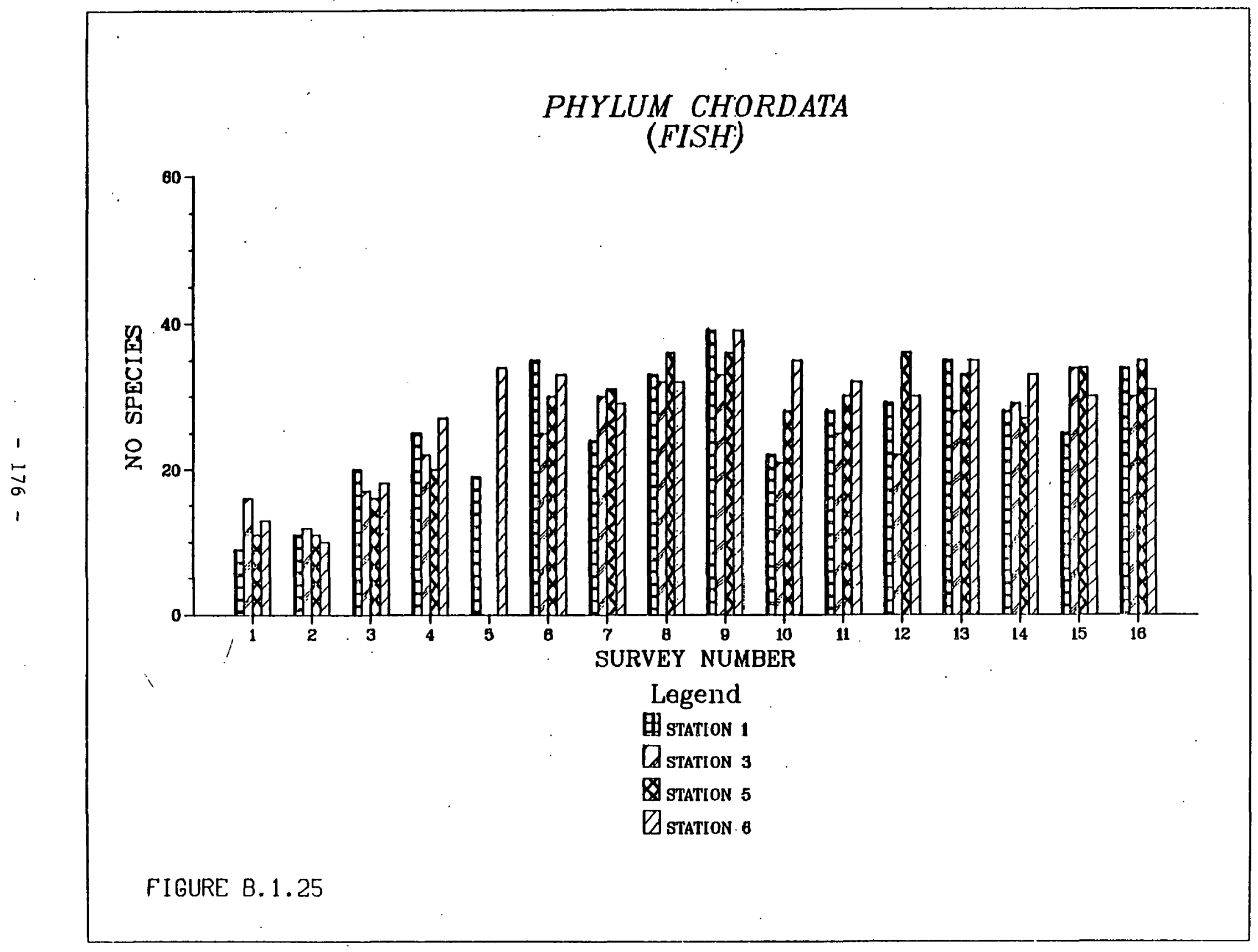




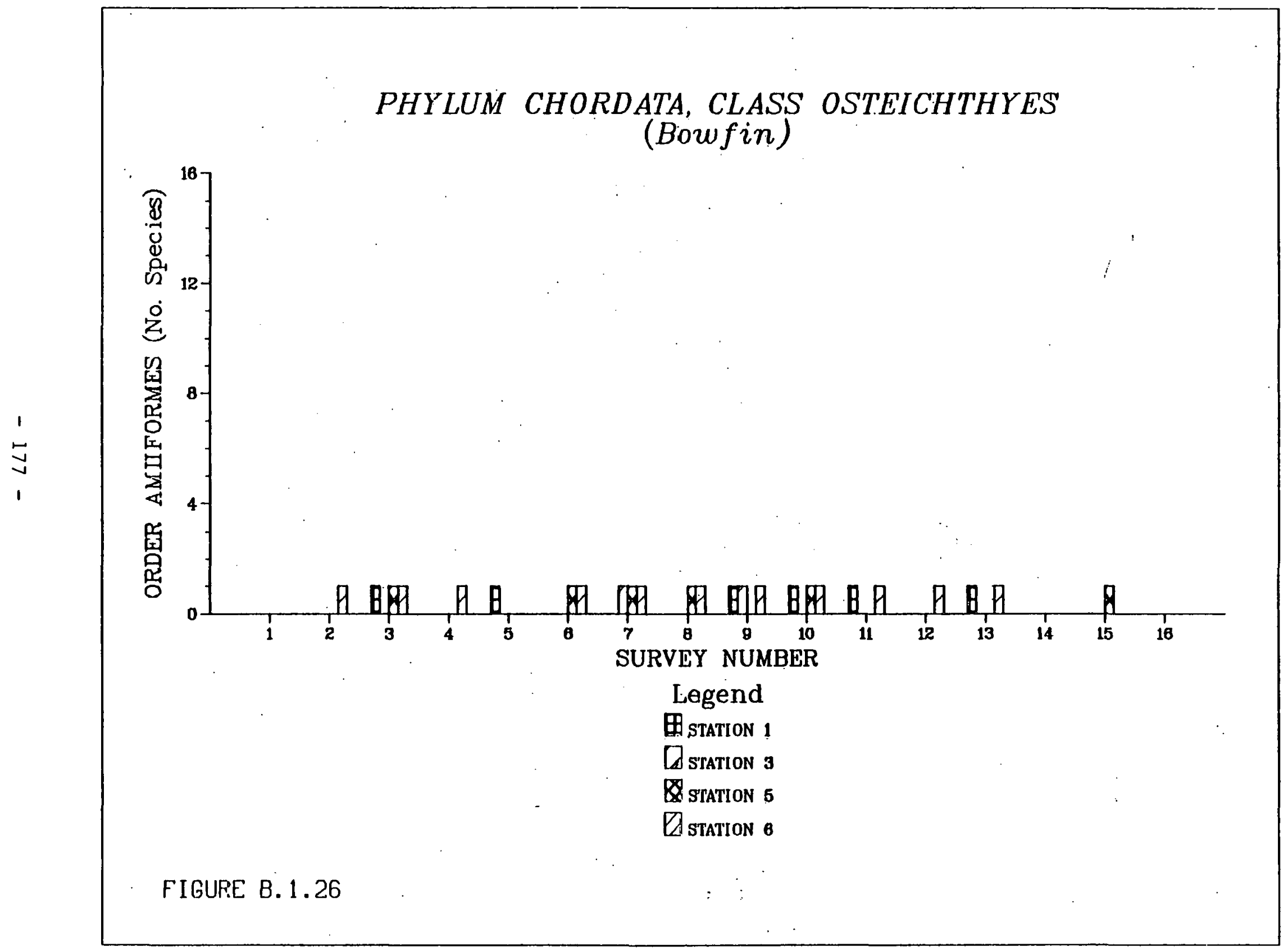




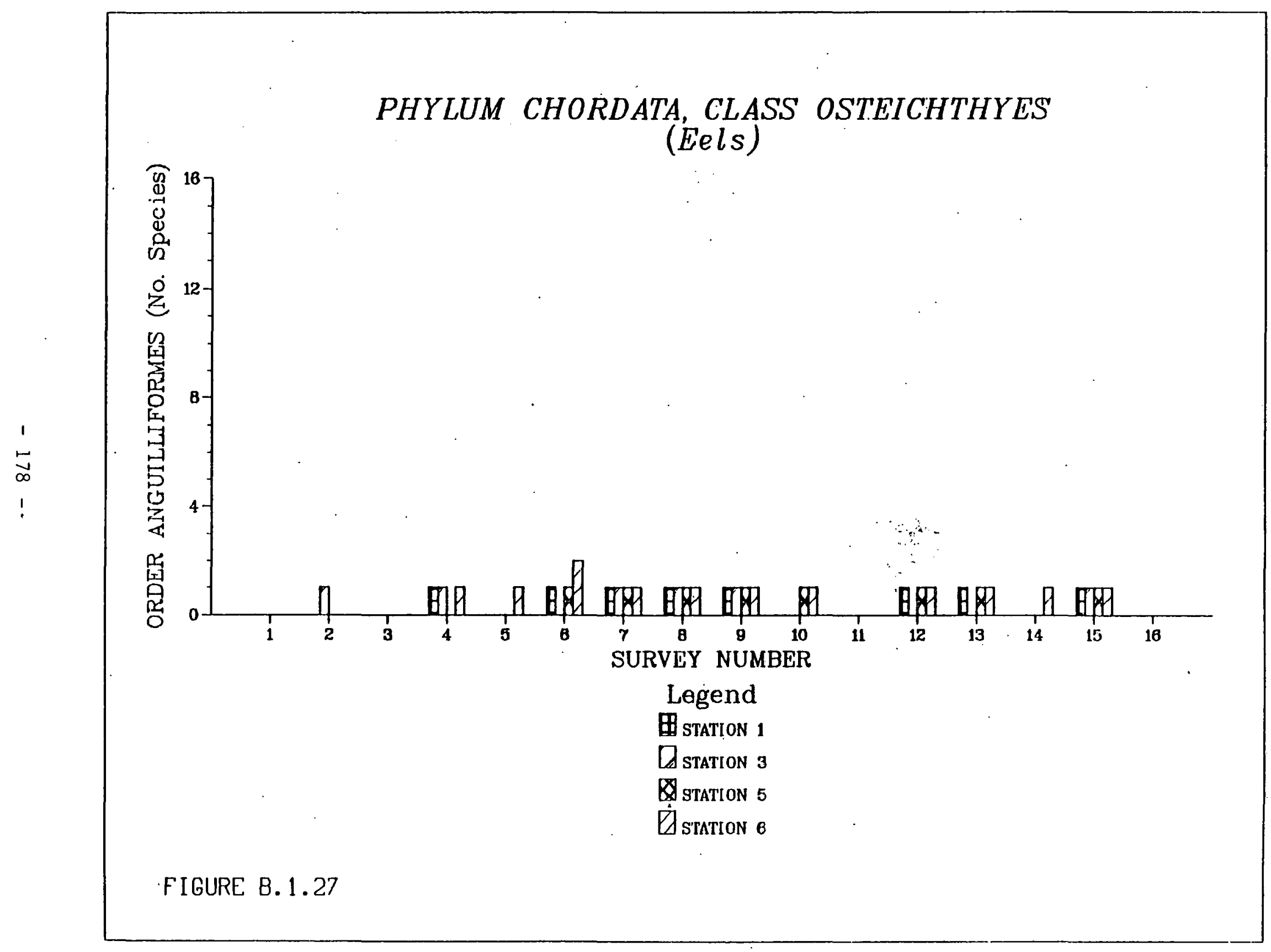




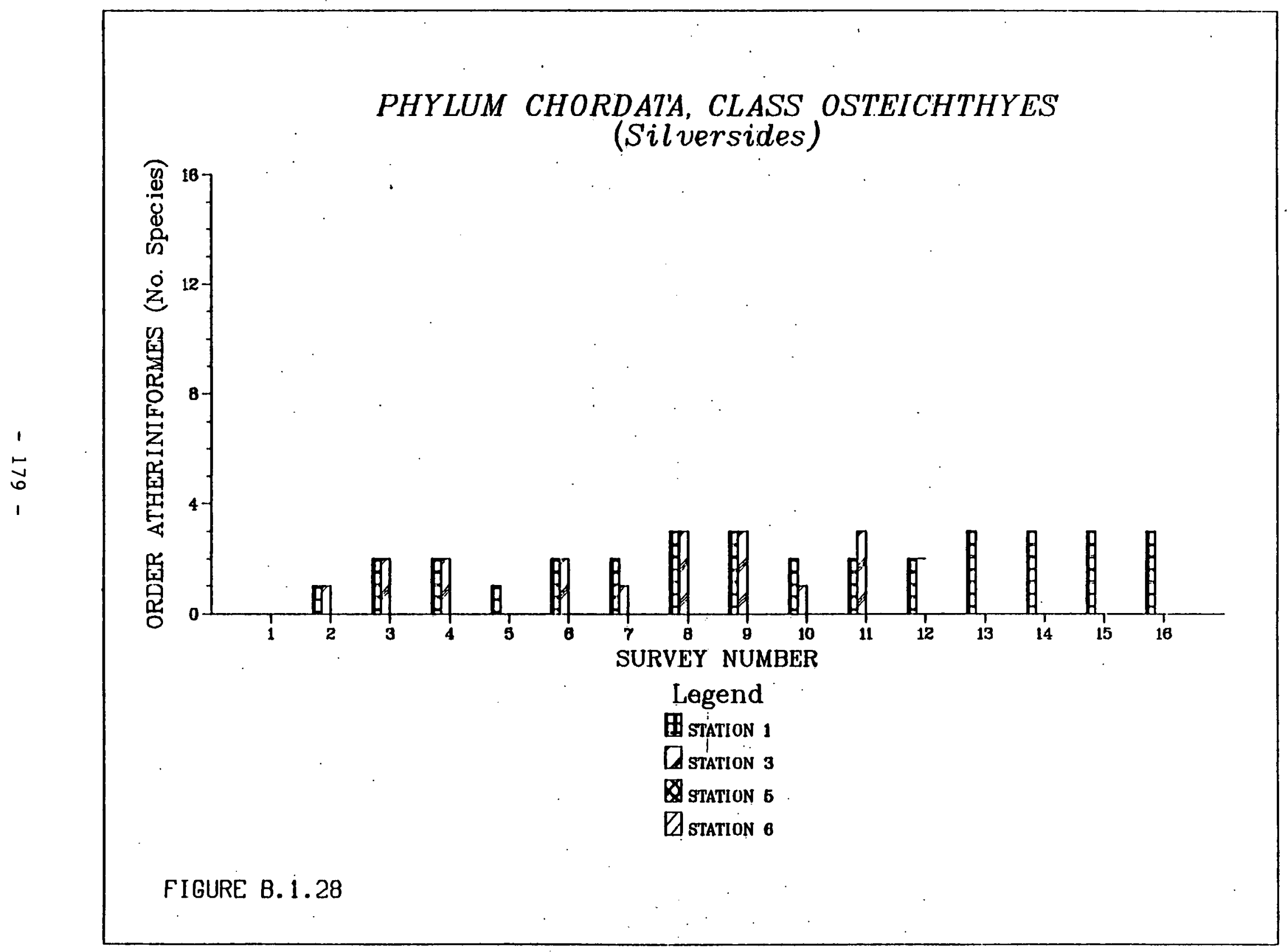




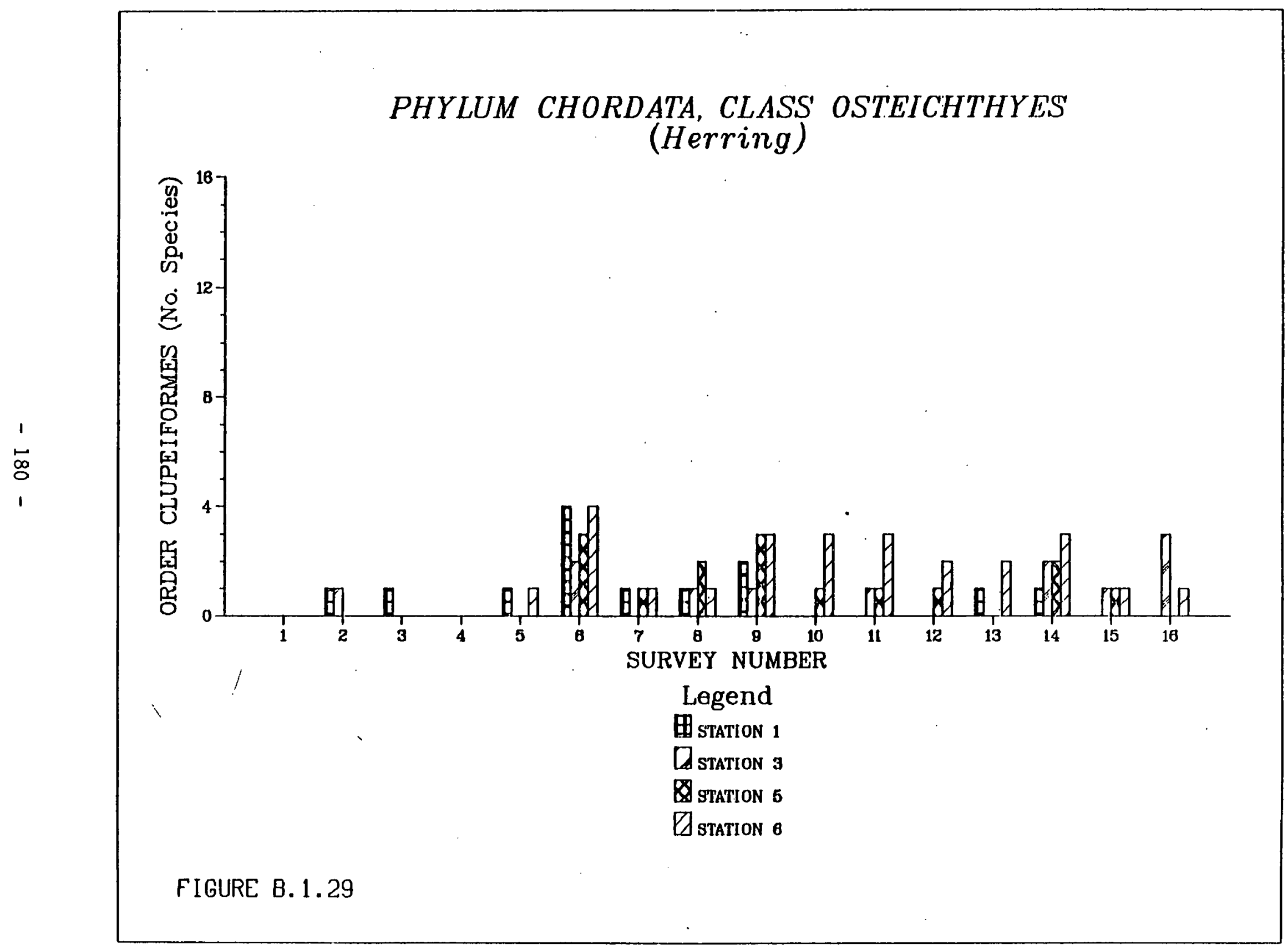




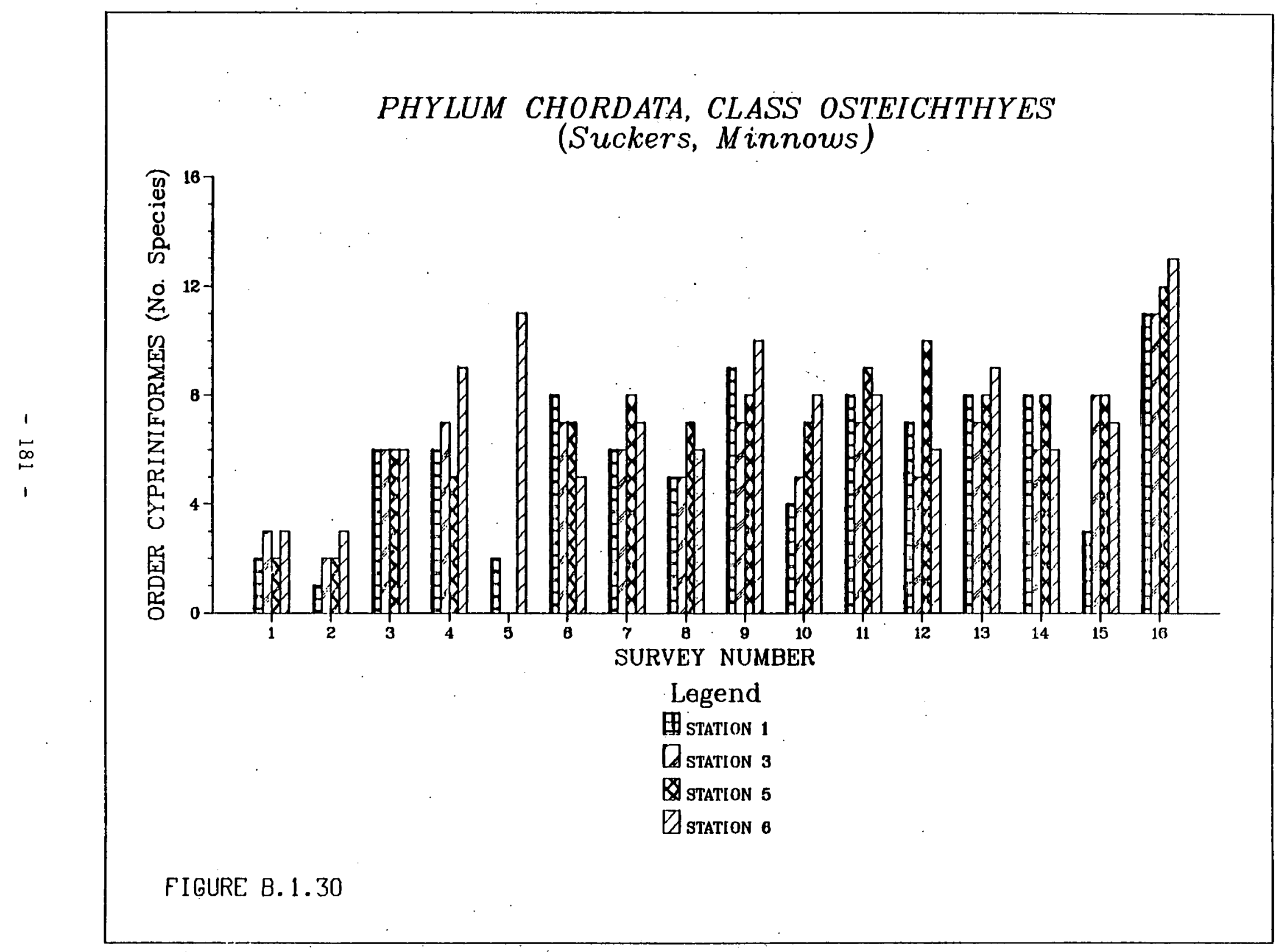




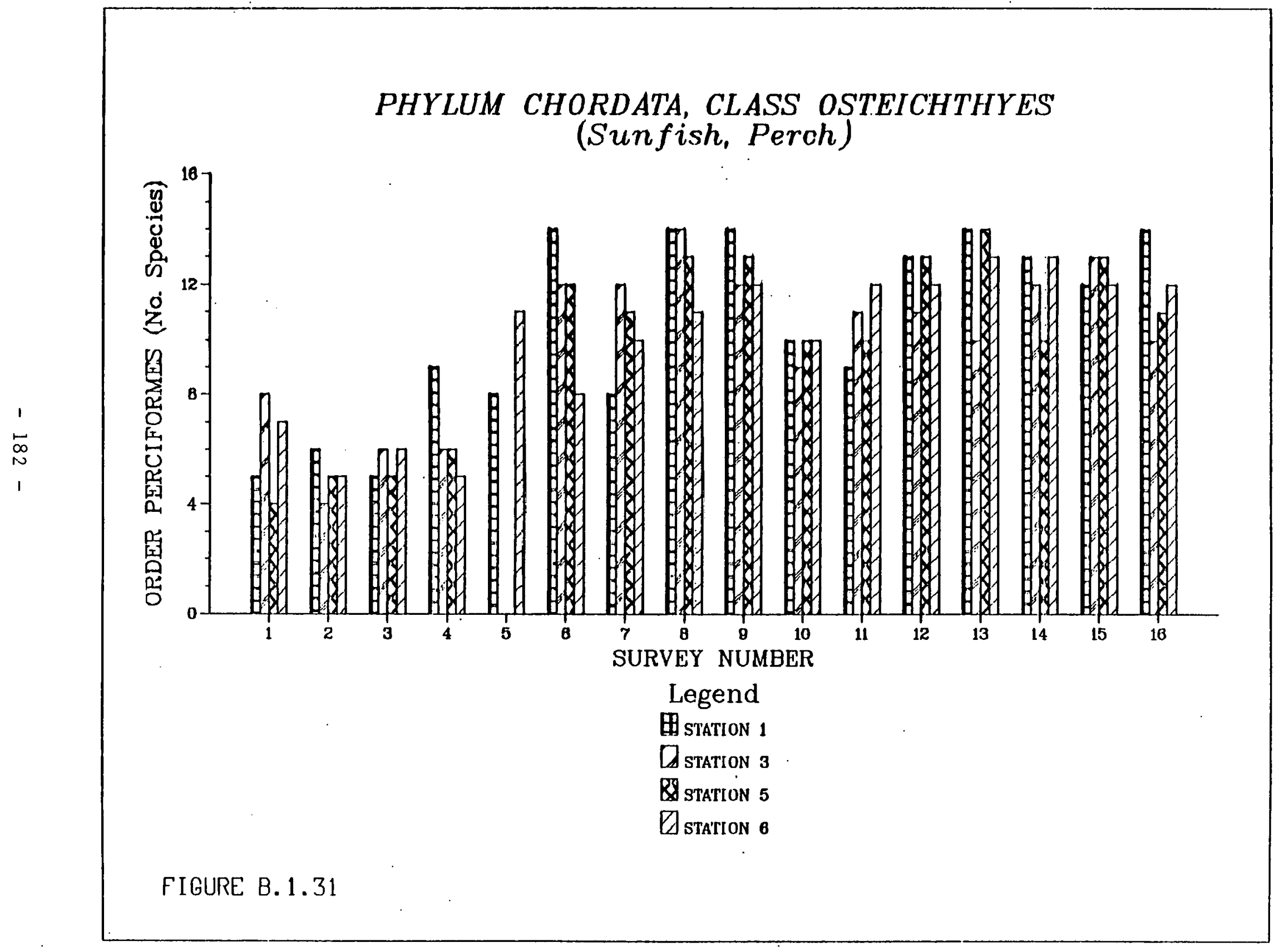




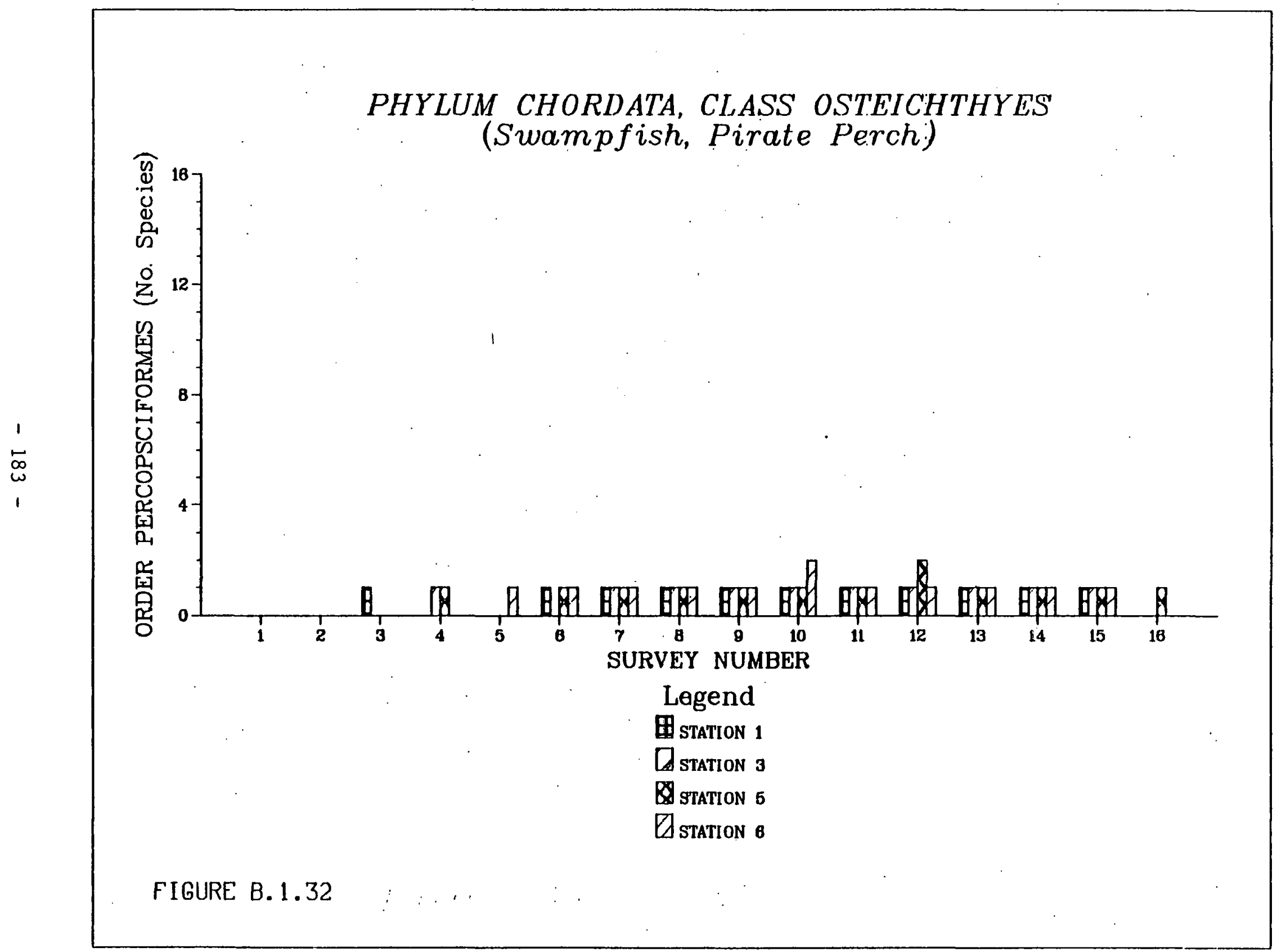




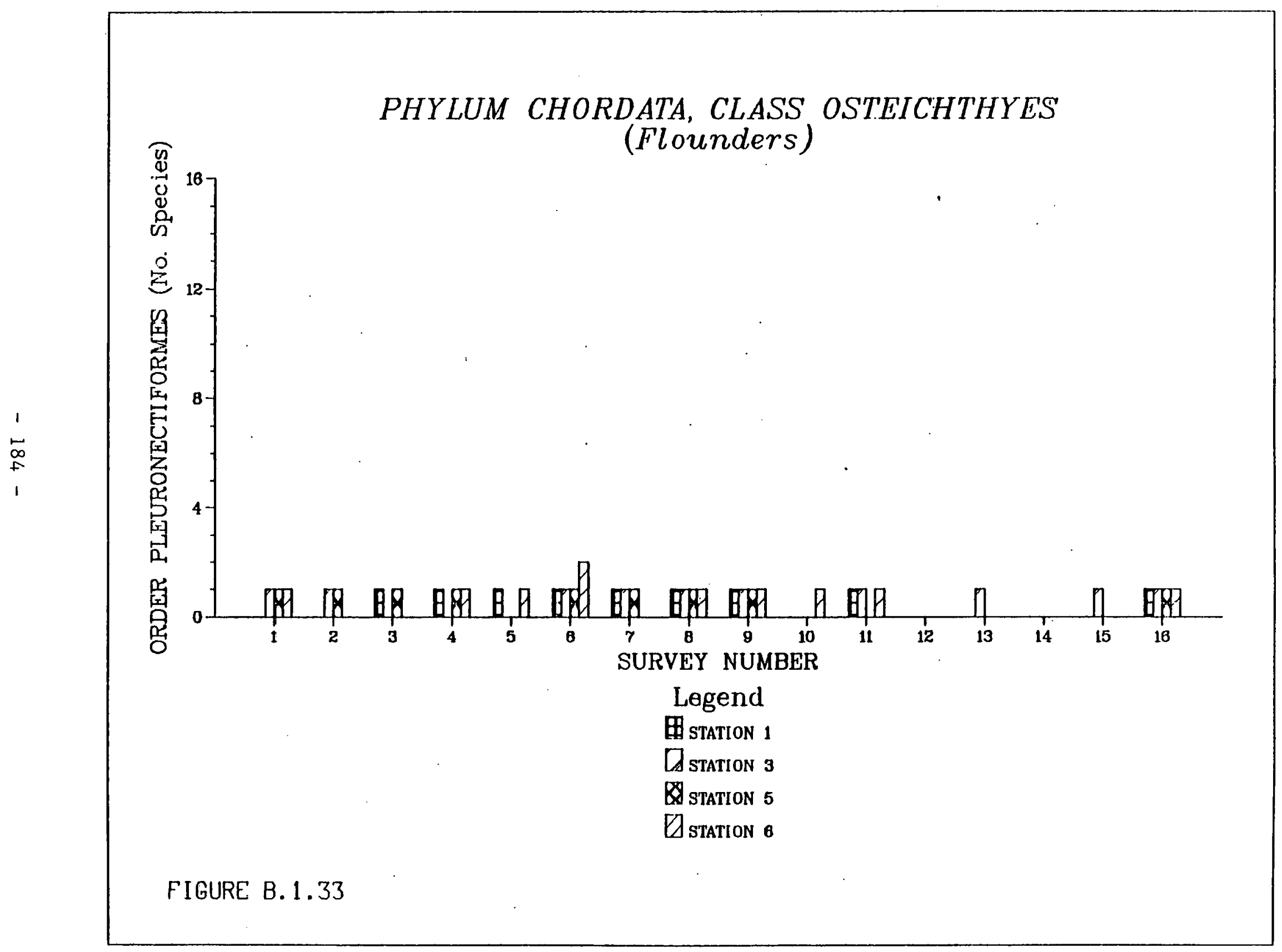




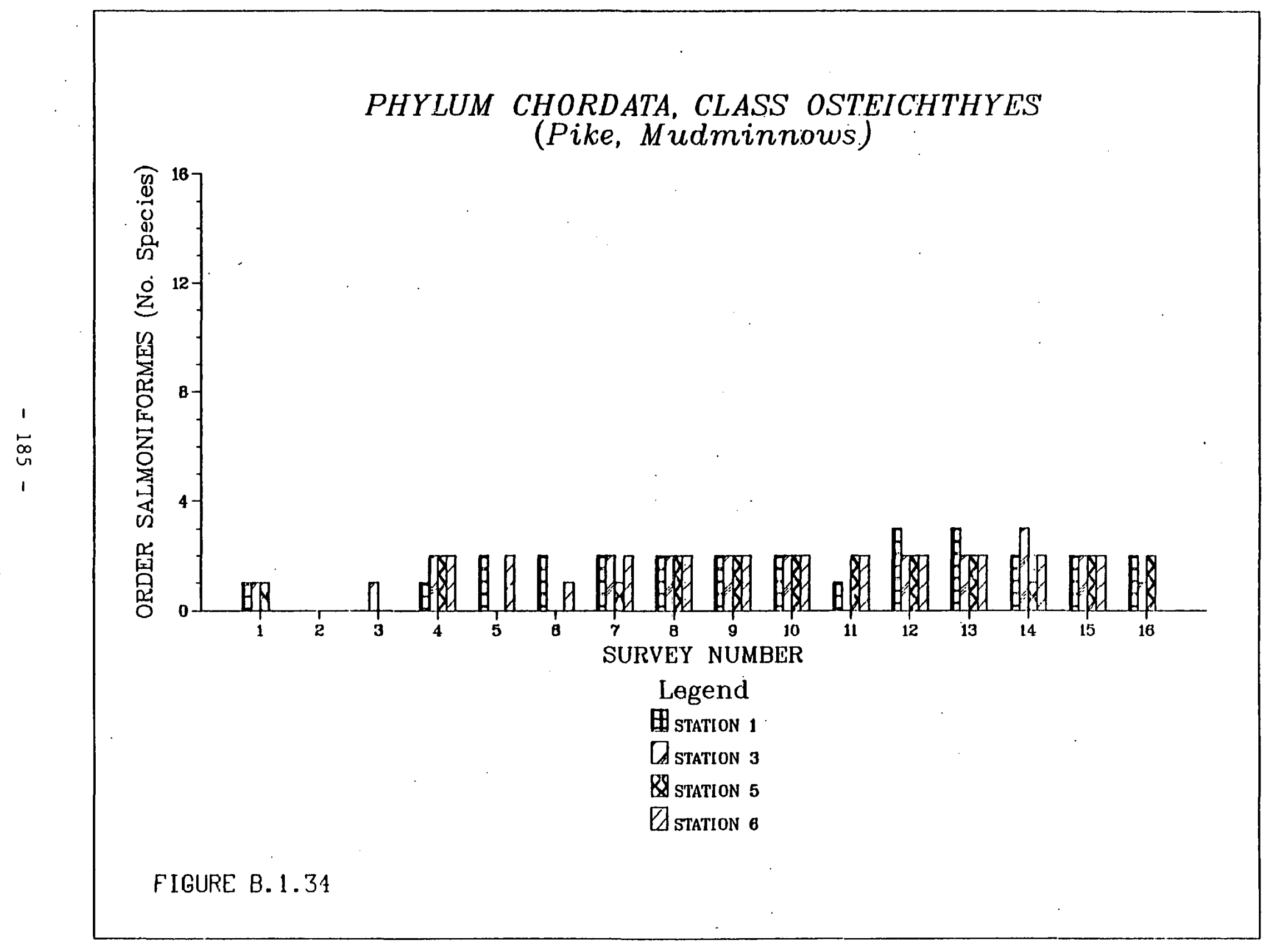




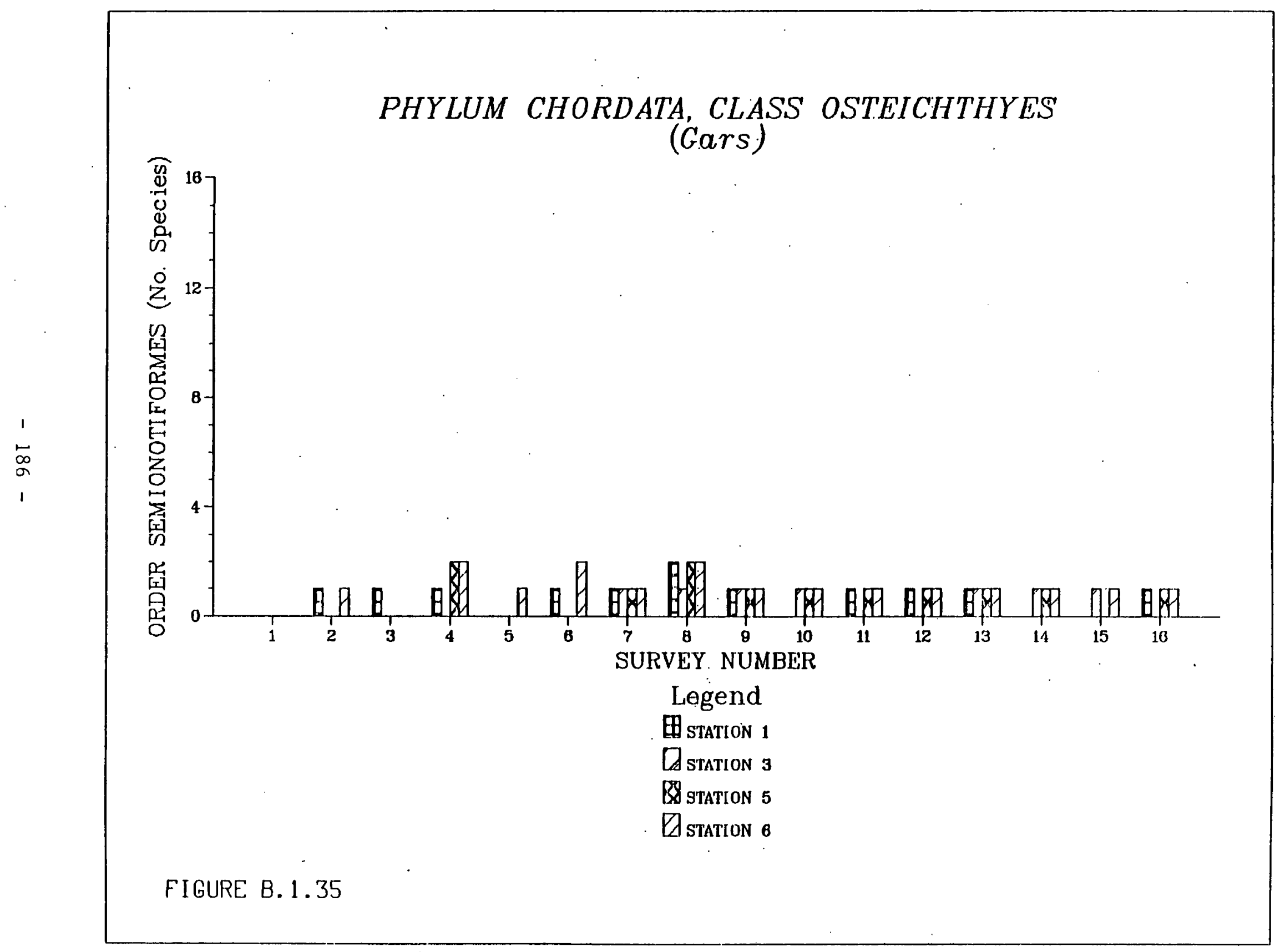




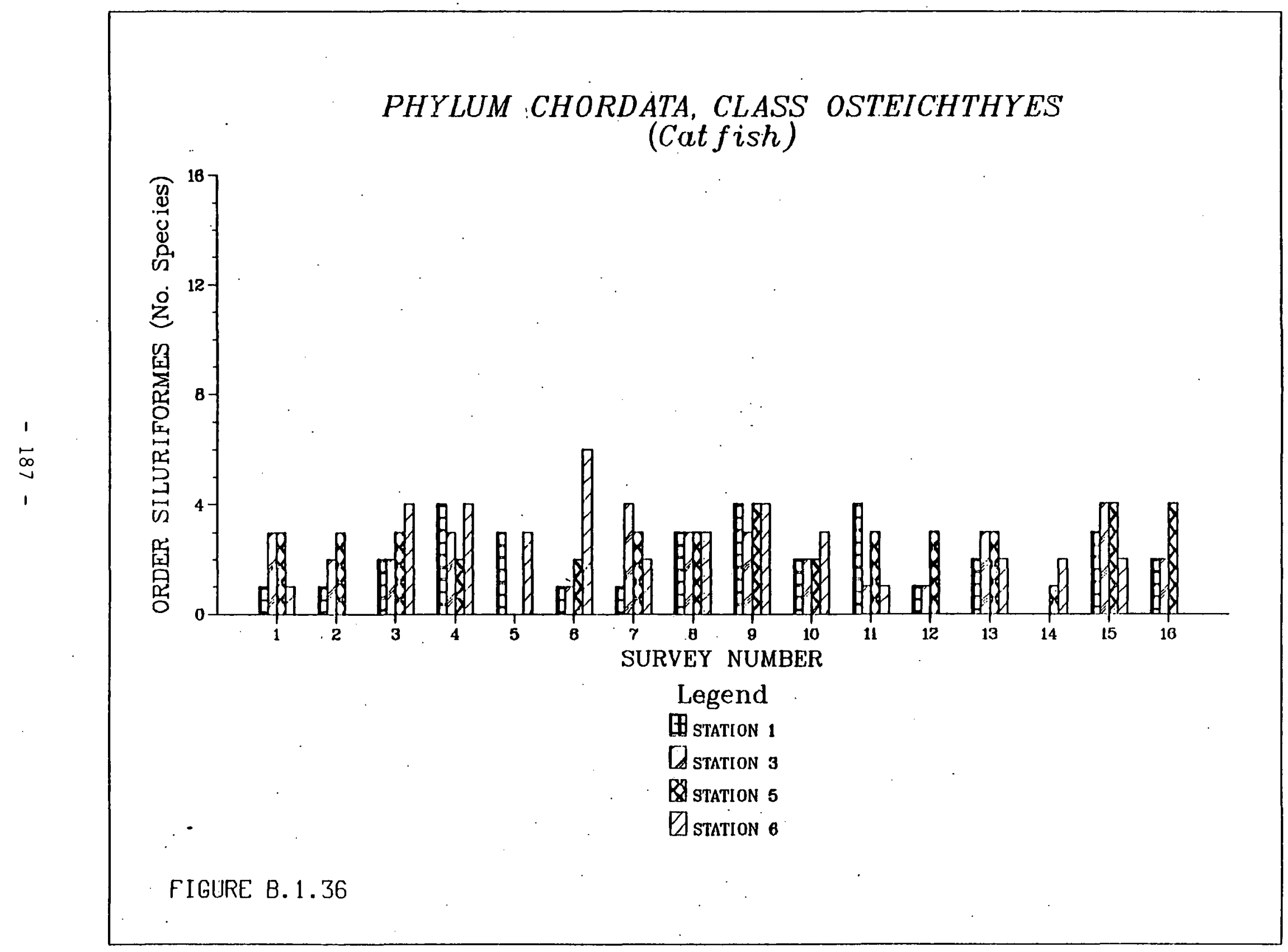




\section{B.2. Sample Presence/Absence Data for Two Diatom Species}

A complete Presence/Absence list is available for each biological organism identified during the surveys. This list is quite extensive. Two representative species from the diatom genus, Gomphonema, have been chosen to show the general format:

G. parvulum Kutz.

$\begin{array}{lrl}\text { Survey } & 1 & \text { Station } 1,3,5,6 \\ \text { Survey } & 2 & \text { Station } 1,3,5,6 \\ \text { Survey } & 3 & \text { Station } 1,3,5,6 \\ \text { Survey } & 4 & \text { Station } 1,3,5,6 \\ \text { Survey } & 5 & \text { Station } 1,6 \\ \text { Survey } & 6 & \text { Station } 1,3,5,6 \\ \text { Survey } & 7 & \text { Station } 1,3,5,6 \\ \text { Survey } & 8 & \text { Station } 1,3,5,6 \\ \text { Survey } & 9 & \text { Station } 1,3,5,6 \\ \text { Survey } & 10 & \text { Station } 1,3,5,6 \\ \text { Survey } & 11 \text { Station } 1,3,5,6 \\ \text { Survey } & 12 \text { Station } 1,3,5,6 \\ \text { Survey } & 13 \text { Station } 1,3,5,6 \\ \text { Survey } & 14 \text { Station } 1,3,5,6 \\ \text { Survey } & 15 \text { Station } 1,3,5,6 \\ \text { Survey } & 16 \text { Station } 1,3,5,6\end{array}$

G. truncatum v. capitatum (Ehr.)

Patr.

Survey 7 Station 1 , Survey 8 Station 1,5

These data indicate that Gomphonema parvulum was present during all the surveys, at nearly.all stations. By contrast, G. truncatum v. capitatum was rarely encountered. 
B.3. Sample Diatometer Data

One way to format the diatometer frequency data is to graph species frequency distributions for each station by survey. Two examples of this type of format are shown in Figures B.3.1 and B.3.2. These figures reflect two different community dominance patterns. Figure B.3.1 indicates that the diatom community was dominated by Gomphonema parvulum, which represented about

50 percent of the total number of individuals counted. Figure B.3.2 shows a diatom community that contains several dominant species, none of which have frequencies greater than about 12 percent. 


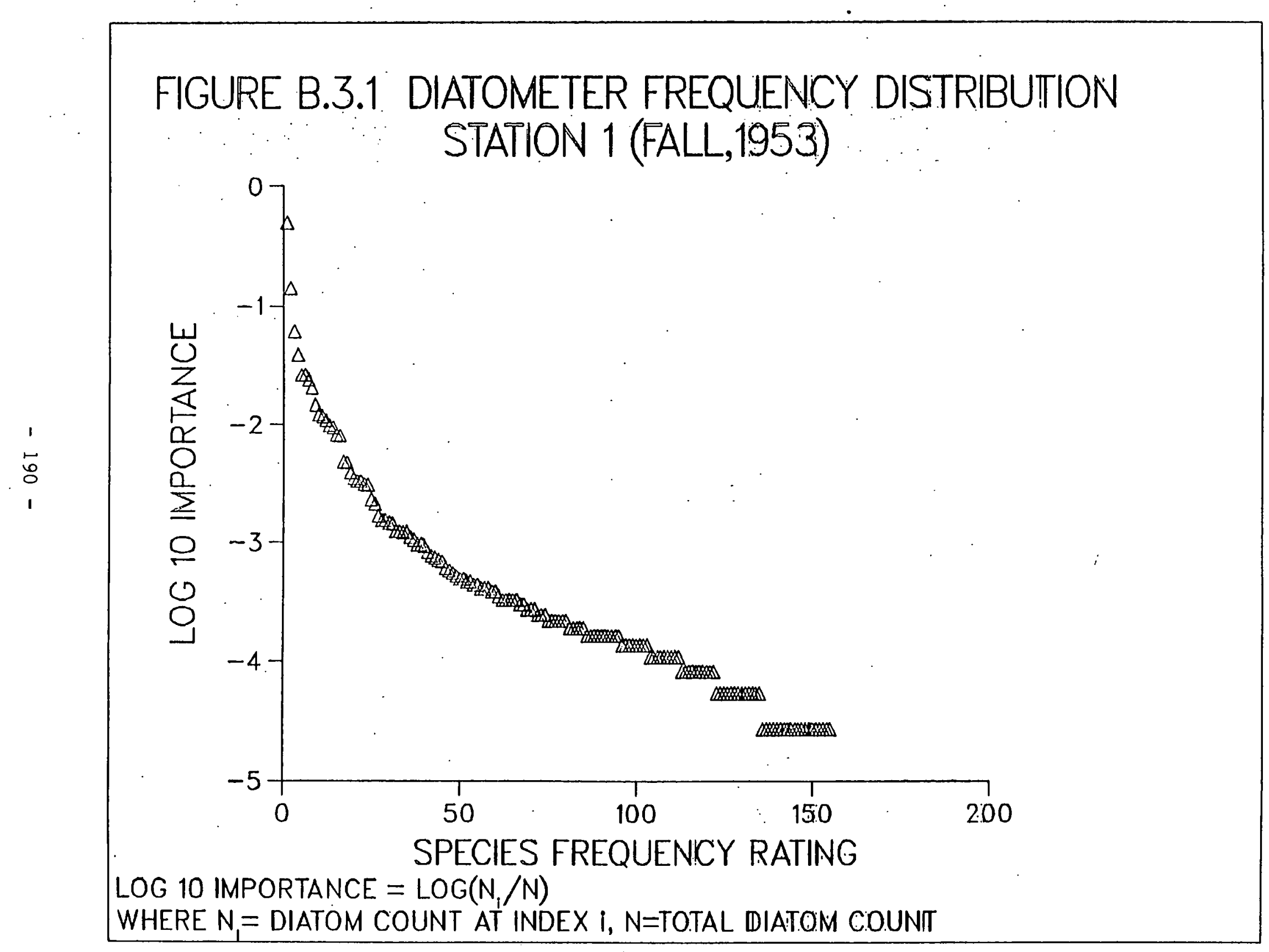


FIGURE B.3.1. Diatometer Frequency Distibution at Station 1 (Fal1 1953)

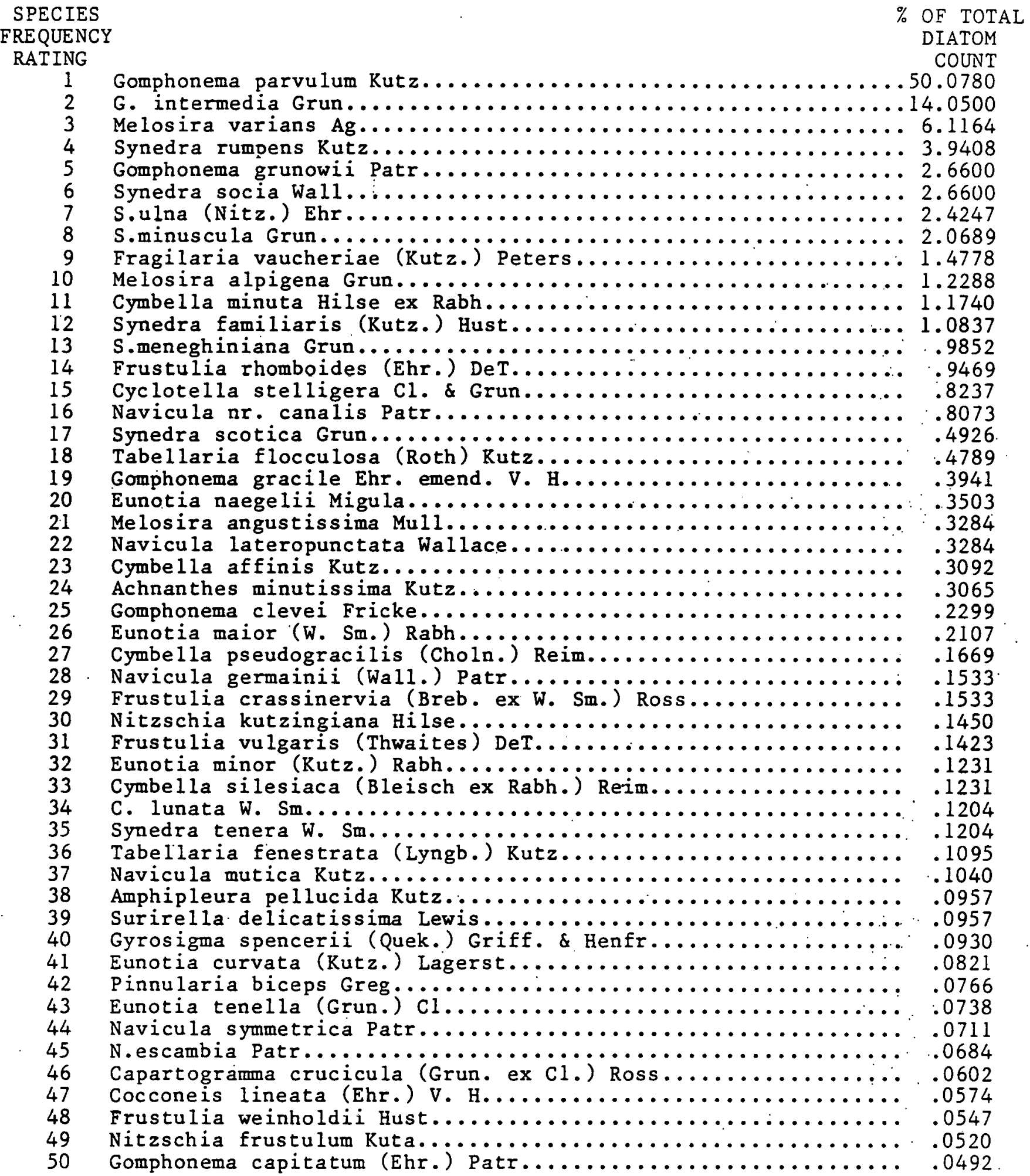


FIGURE B.3.1. (Contd)

SPECIES

FREQUENCY

RAT ING

\% OF TOTAL

DIATOM

COUNT

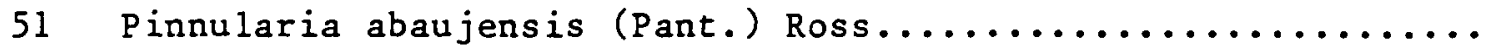

.0492

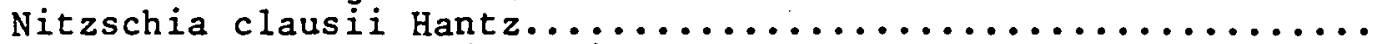

.0465

Synedra oxyrhynchus (Kutz.) $\mathrm{v} . \mathrm{H} \ldots \ldots \ldots \ldots \ldots \ldots \ldots \ldots \ldots \ldots \ldots$

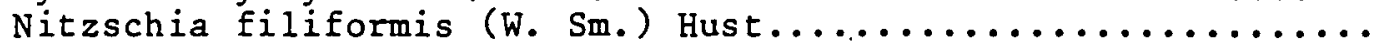

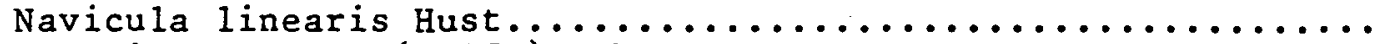

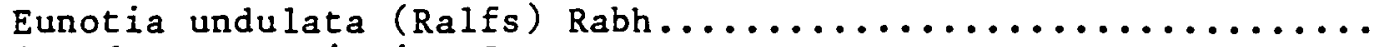

Synedra angustissima Grun...........................

Fragilaria subcapitata Freng.........................

Achnanthes heterovalva Krasske........................

Navicula menisculus schum...........................

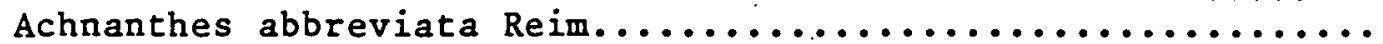

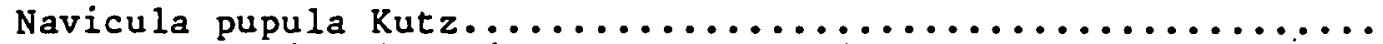

Cymbella naviculiformis Auersw. ex Heib.................

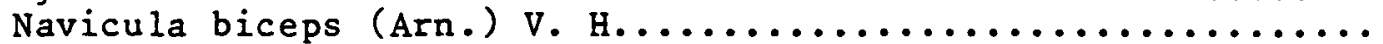

Opephora martyi Herib.............................

Bacillaria paradoxa Gmel...........................

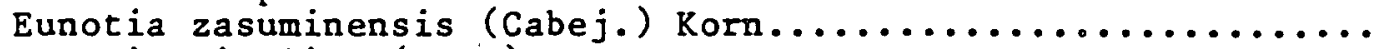

Melosira italica (Ehr.) Kutz.........................

Nitzschia intermedia Hantz. ex $\mathrm{Cl}$. \& Grun.................

Cymbella aspera (Ehr.) H. Per.........................

Navicula cryptocephala Kutz..........................

Cyclotella meneghiniana Kutz..........................

Pinnularia obscura Krasske...........................

Surirella ovata Kutz..............................

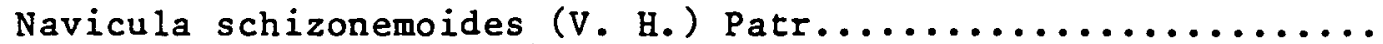

Epithemia adnata (Kutz.) Breb........................

E.turgida (Ehr.) Kutz..............................

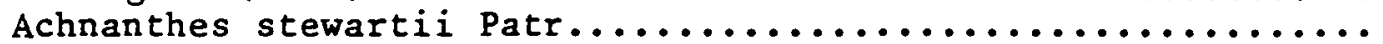

Nitzschia amphibia Grun.............................

Synedra sp. 1..................................

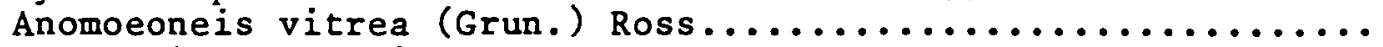

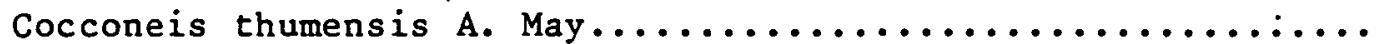

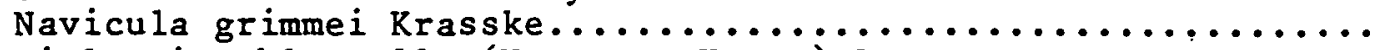

Diploneis oblongella (Naeg. ex Kutz.) Ross................

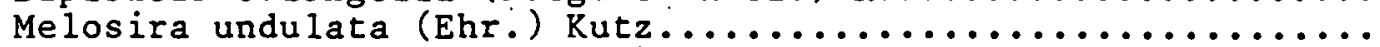

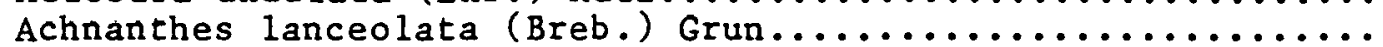

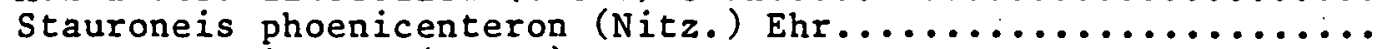

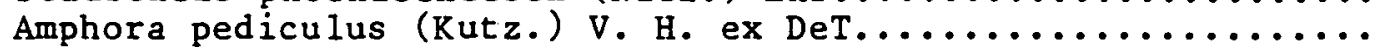

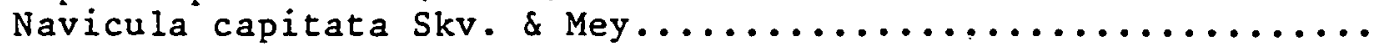

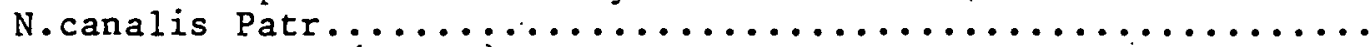

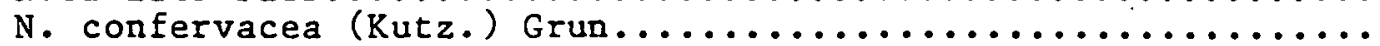

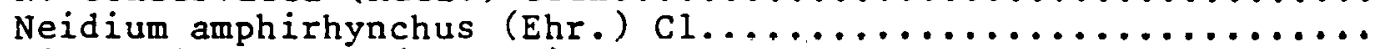

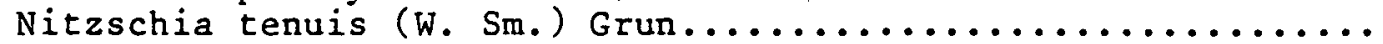

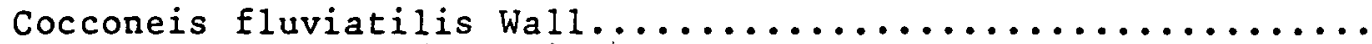

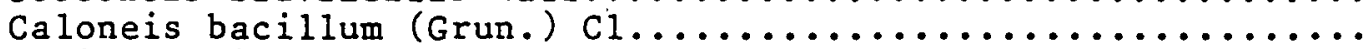

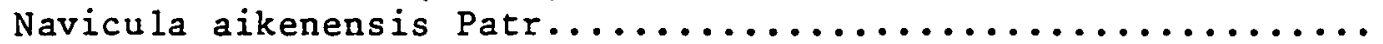

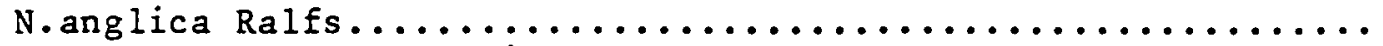
Cyclotella pseudostelligera Hust..................... Gomphonema brasiliense Grun..........................

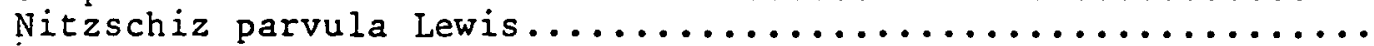

.0465

.0437

.0437

.0410

.0410

.0410

.0383

.0383

.0355

.0328

.0328

.0328

.0328

.0328

.0301

.0301

.0273

.0273

.0273

.0246

.0246

.0246

.0218

.0218

.0218

.0218

.0218

.0218

.0191

.0191

.0191

.0191

.0191

.0164

.0164

.0164

.0164

.0164

.0164

.0164

.0164

.0164

.0164

.0136

.0136

.0136

.0136

.0136 
FIGURE B.3.1. (Contd)

SPECIES

FREQUENCY

$\%$ OF TOTAL

DIATOM

RATING

COUNT

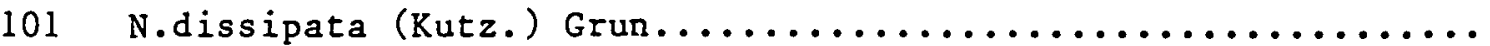

102

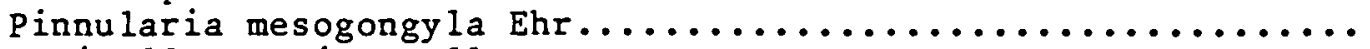

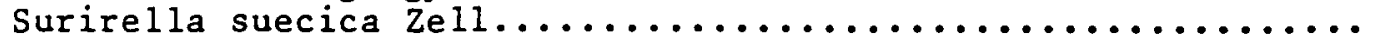

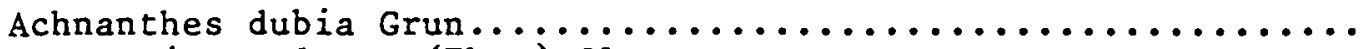

105

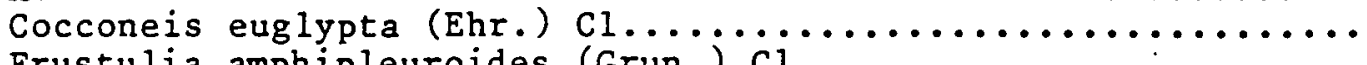

106

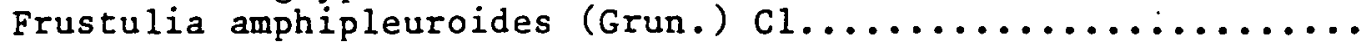

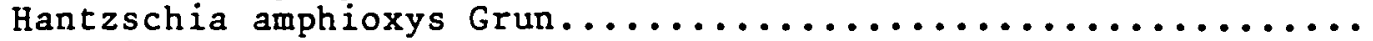

108

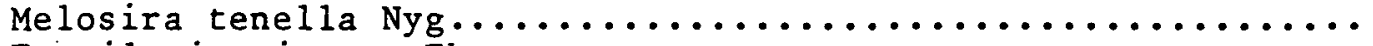

109

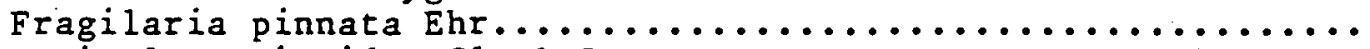

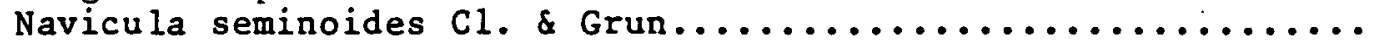

111

112

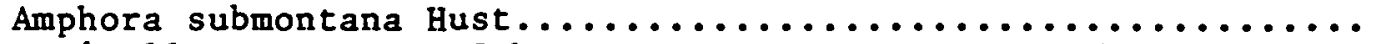

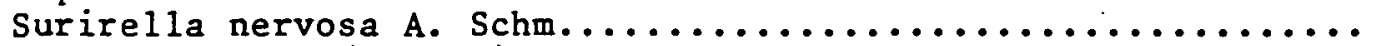

113

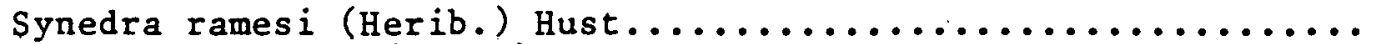

114

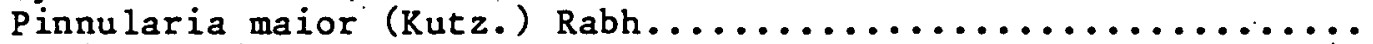

115

116

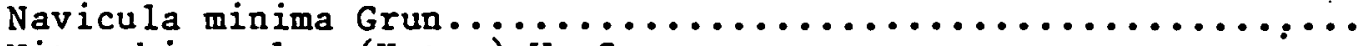

117

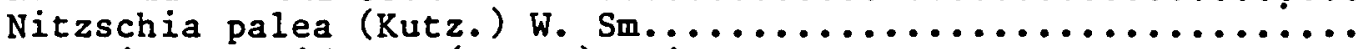

118

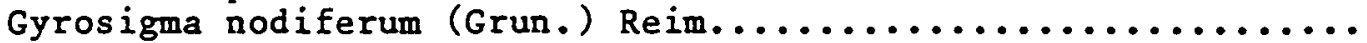

119

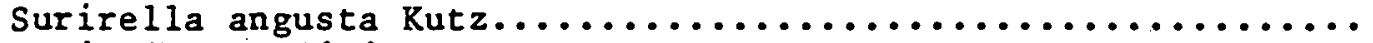

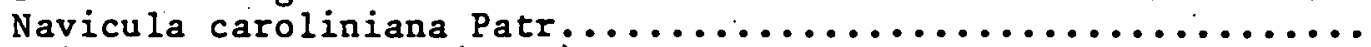

120

121

122

123

124

125

126

127

128

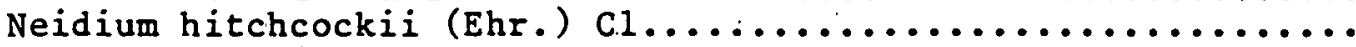

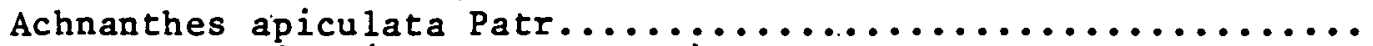

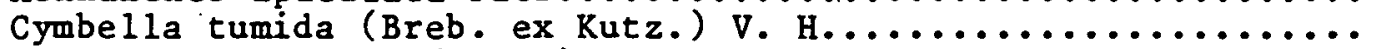

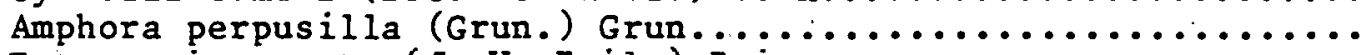

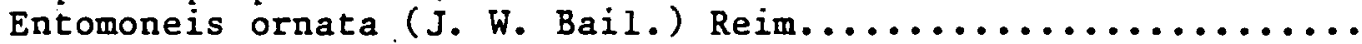

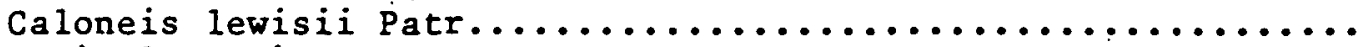

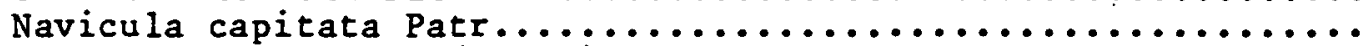

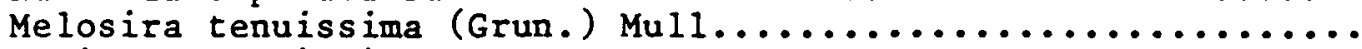

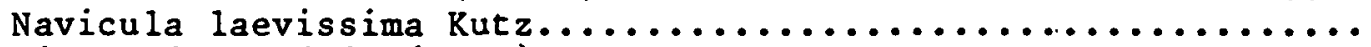

129

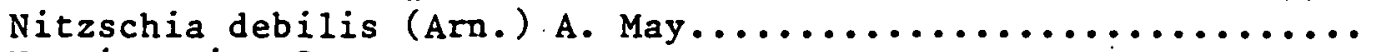

130

131

132

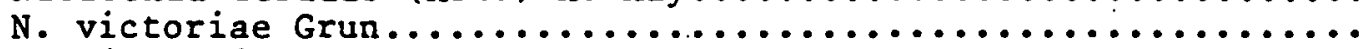

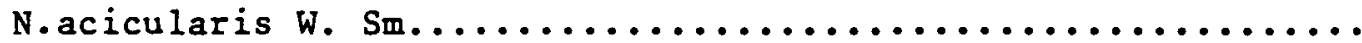

133

134

135

136

137

138

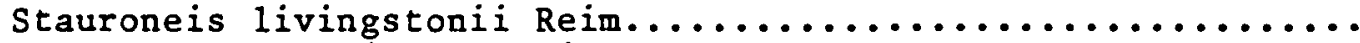

Gomphonema grovei M. Schmidt.....................

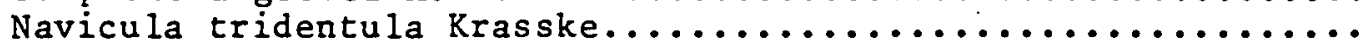

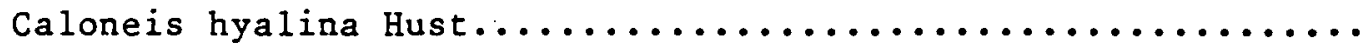

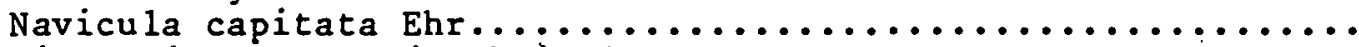

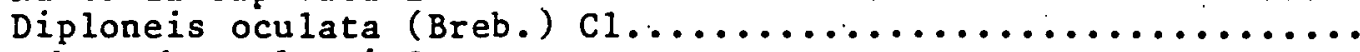

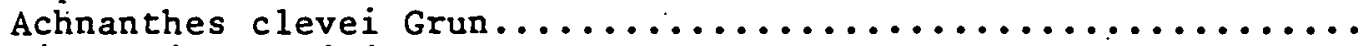

139

140

141

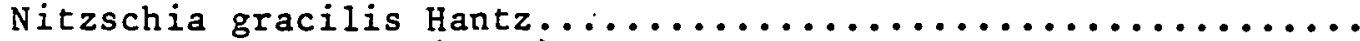

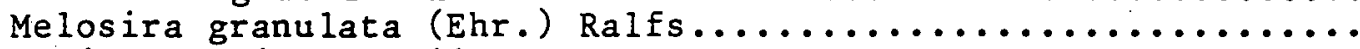

142

143

144

145

146

147

148

149

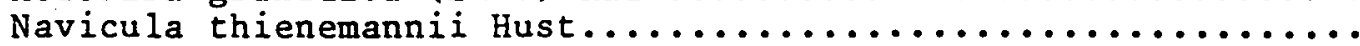

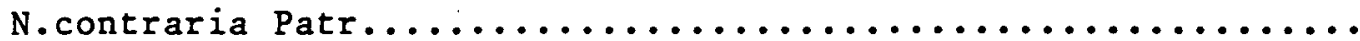

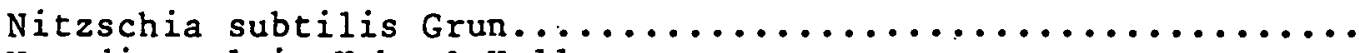

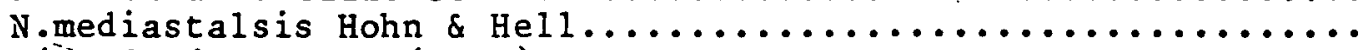

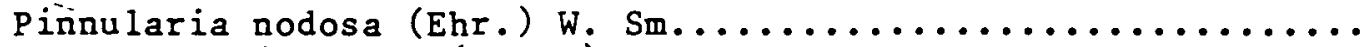

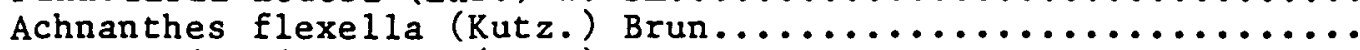

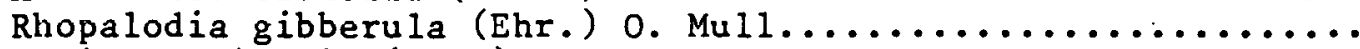

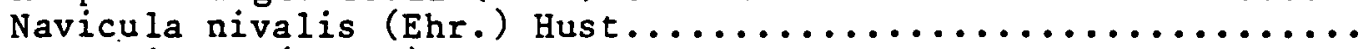

150

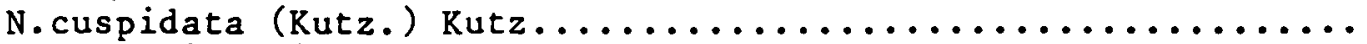

Stauroneis smithii Grun...........................

.0136

.0136

.0136

.0109

.0109

.0109

.0109

.0109

.0109

.0109

.0109

.0109

.0082

.0082

.0082

.0082

.0082

.0082

.0082

.0082

.0082

.0082

.0054

.0054

.0054

.0054

.0054

.0054

.0054

.0054

.0054

.0054

.0054

.0054

.0054

.0027

.0027

.0027

.0027

.0027

.0027

.0027

.0027

.0027

.0027

.0027

.0027

.0027

.0027

.0027 
FIGURE B.3.1. (Contd)

SPECIES

FREQUENCY

$\%$ OF TOTAL DIATOM

RATING COUNT

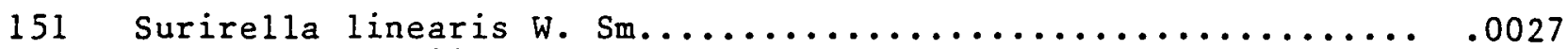

152 Amphora normanii Rabh...........................0027

153 Surirella stalagma Hohn \& Hell.....................0027

154 Synedra danica (Kutz.) V. H........................0027

155 Nitzschia subconstricta Grun...................... .0027 


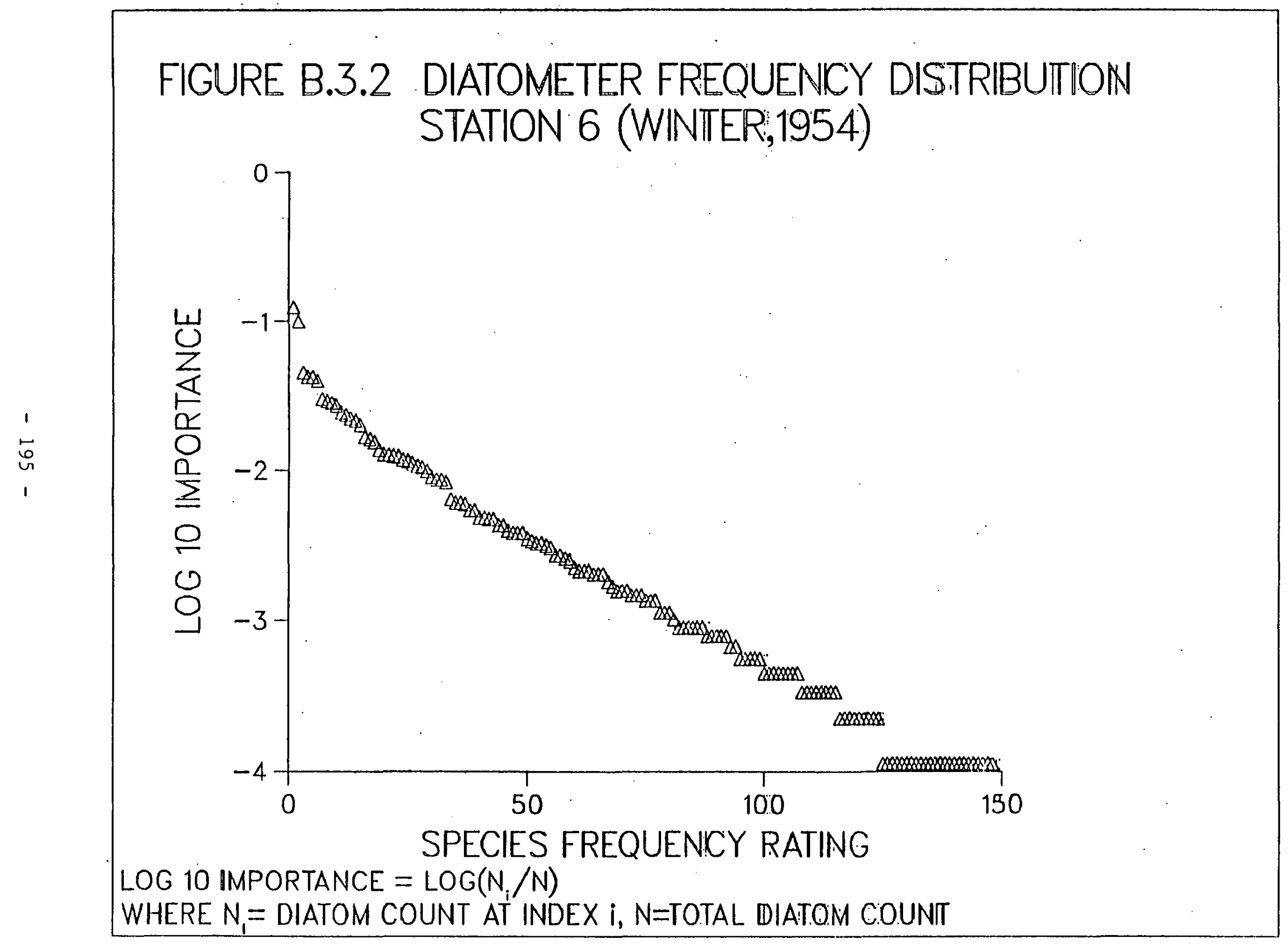


SPECIES

FREQUENCY

RATING

1

2

3

4
Synedra ulna (Nitz.) Ehr.

Gomphonema parvulum Kutz

Melosira alpigena Grun...............................

Navicula cryptocephala Kutz.........................

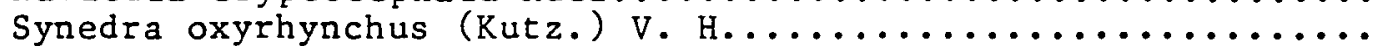
S. rumpens Kutz................................. Melosira varians Ag.............................. Fragilaria mesolepta Rabh..........................

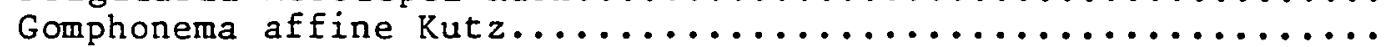
Achnanthes minutissima Kutz.........................

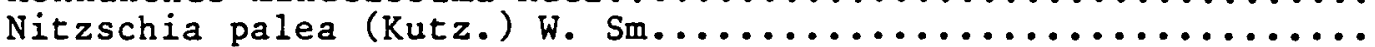

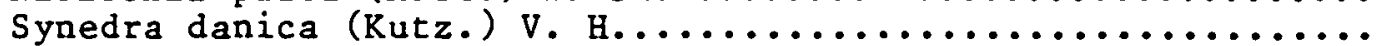

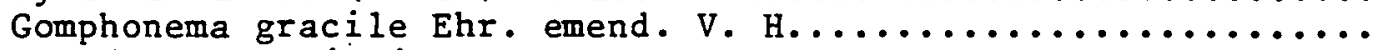
Synedra augustissima Grun..........................

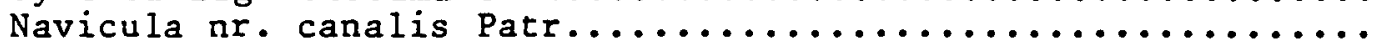

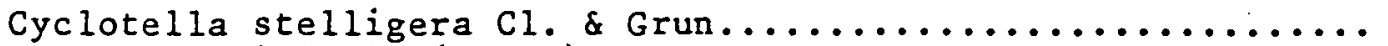

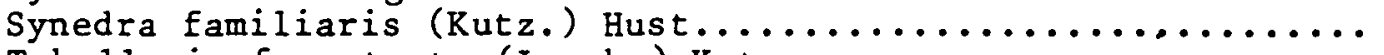

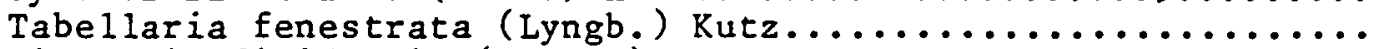

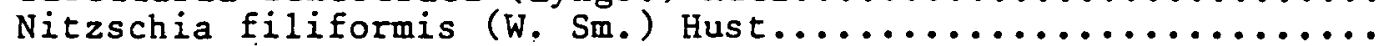
Gomphonema capitatum (Ehr.) Patr....................... G.productum Grun.................................

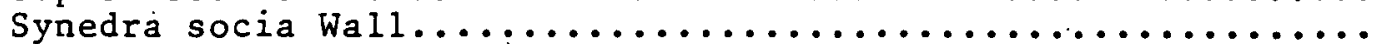

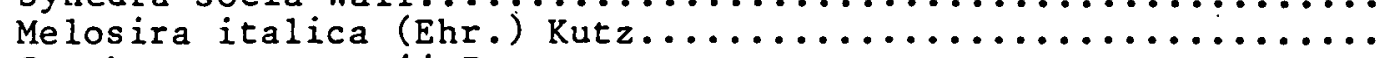
Gomphonema grunowii Patr..........................

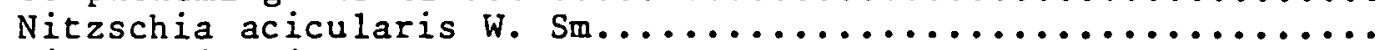

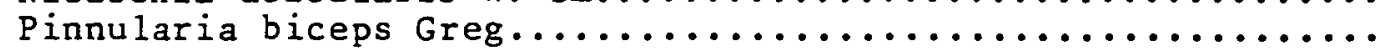

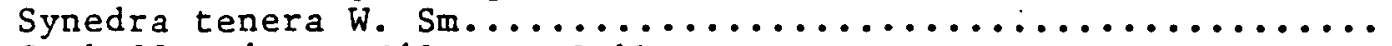

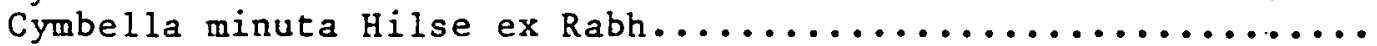

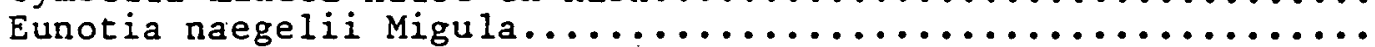
Navicula lateropunctata Wallace.......................

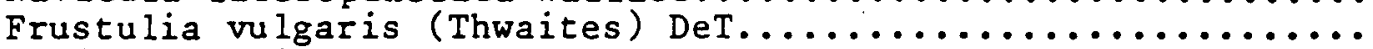
Navicula mutica Kutz................................ N. Thynchocephala Kutz.............................

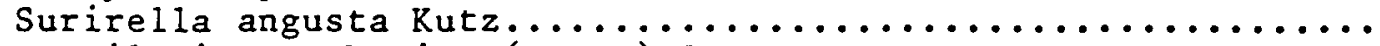

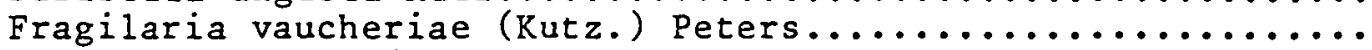

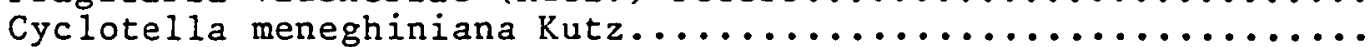
Synedra meneghiniana Grun...........................

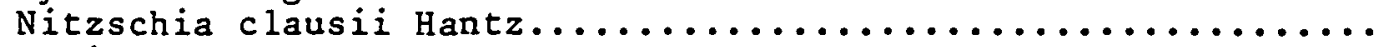
Surirella ovata Kutz..............................

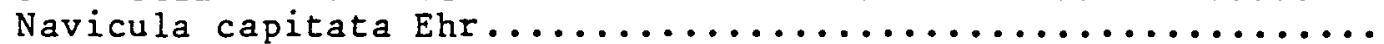

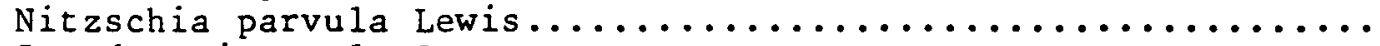
Synedra minuscula Grun..............................

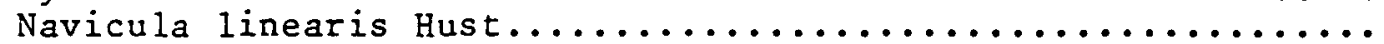

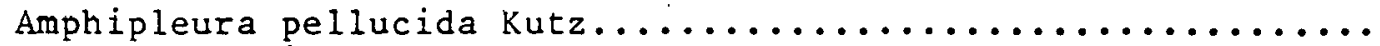
Synedra scotica Grun...............................

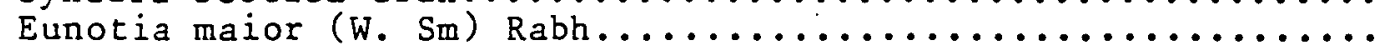

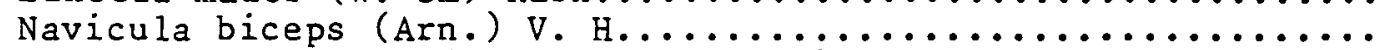

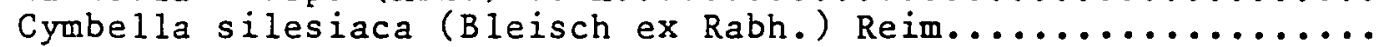

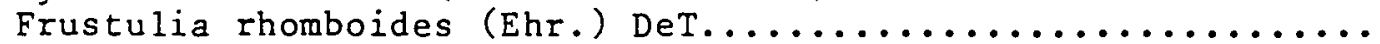

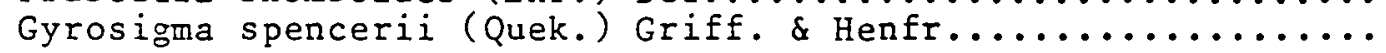

\% OF TOTAL DIATOM COUNT 12.4112

9.9650

4.5316

4. 2273

4.1934

3. 9680

2. 9985

2.8971

2.8182

2. 7054

2.4349

2. 3447

2. 2094

2. 1418

2.0065

1.6684

1. 6120

1. 5331

1. 3640

1. 2851

1. 2738

1. 2513

1.2400

1.1836

1. 1498

1. 1160

1.0709

1.0371

.9807

.9018

.8680

.8680

.8342

.6425

.6087

.6087

.5975

.5411

. 5411

.4847

.4847

.4735

.4735

.4284

.4284

. 3945

.3833

.3833

.3833

.3495 
FIGURE B.3.2. (Contd)

SPECIES

FREQUENCY

RATING

51

52

53

54

55

56

57

58

59

60

61

62

63

64

65

66

67

68

69

70

71

72

73

74

75

76

77

78

79

80

81

82

83

84

85

86

87

88

89

90

91

92

93

94

95

96

97

98

99

100

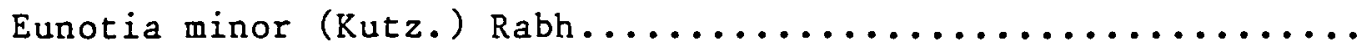

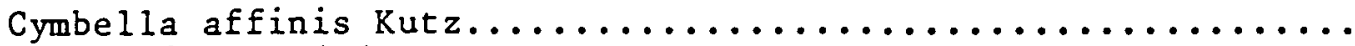

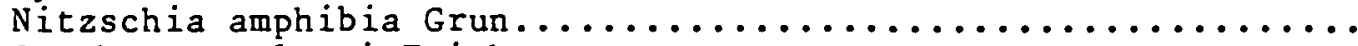

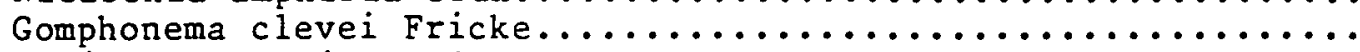

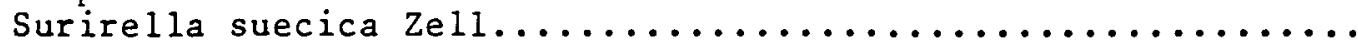

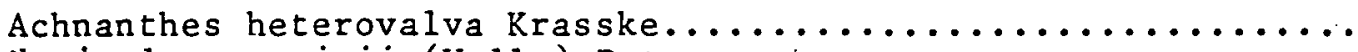

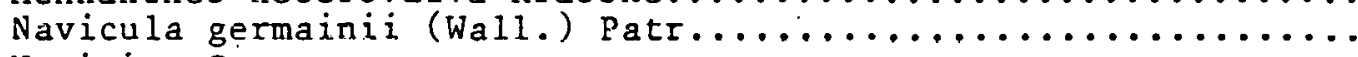

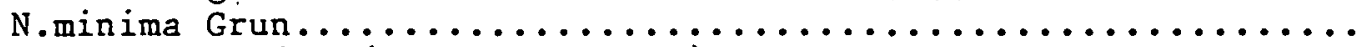

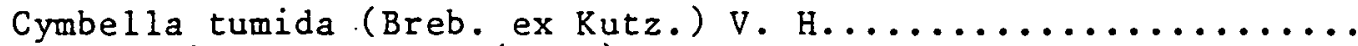

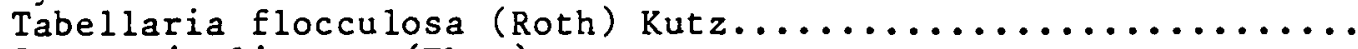

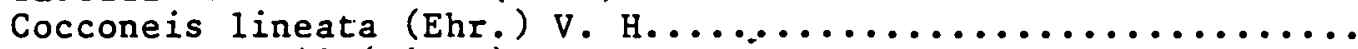

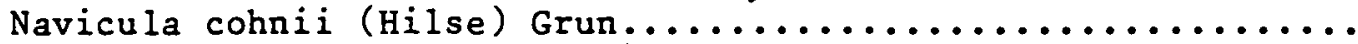

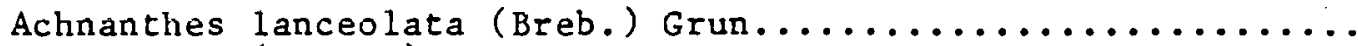

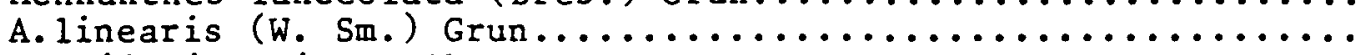

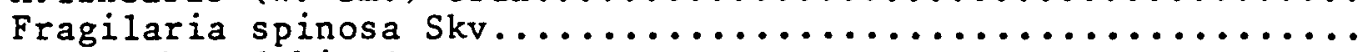

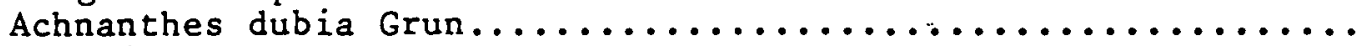

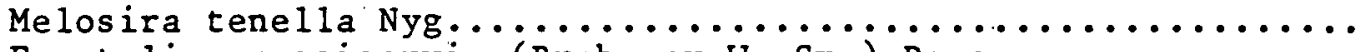

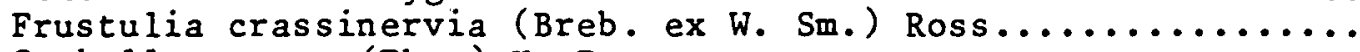
Cymbella aspera (Ehr.) H. Per........................

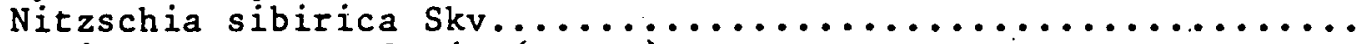

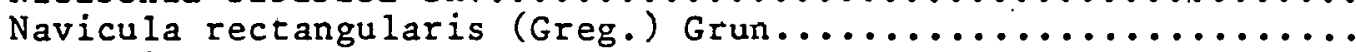

N. tropica Hust.................................

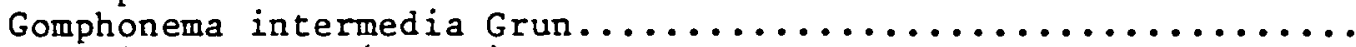

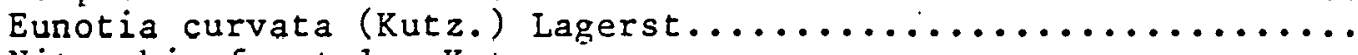

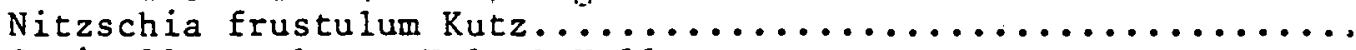

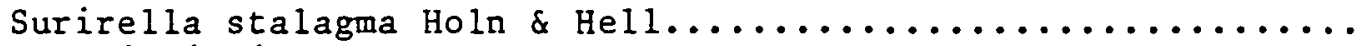

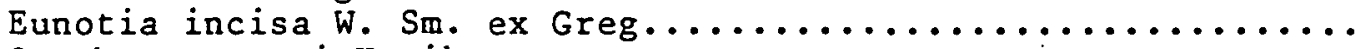

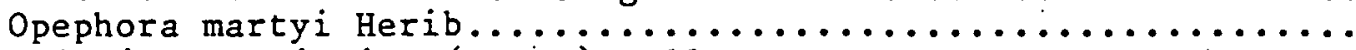

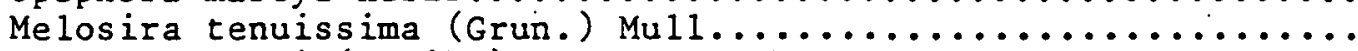

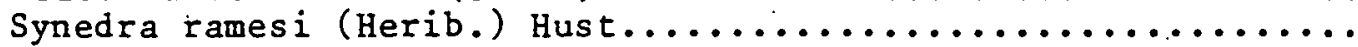

Navicula capitata Skv. \& Mey..........................

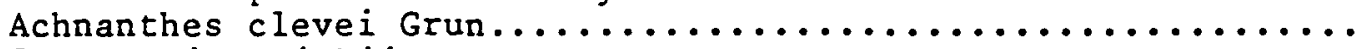

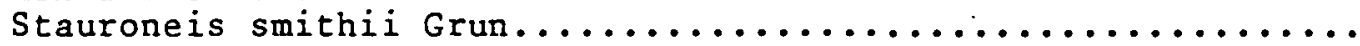

Fragilaria subcapitata Freng.........................

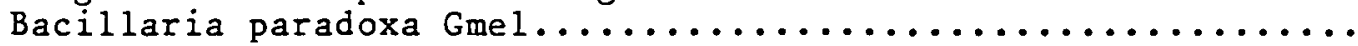

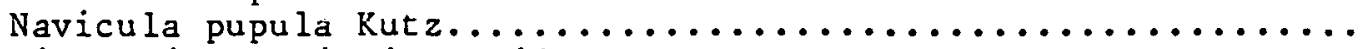

Nitzschia kutzingiana Hilse.........................

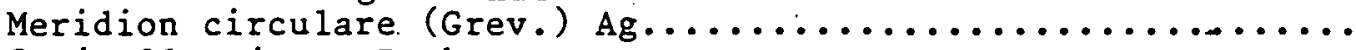

Surirella minuta Breb.............................

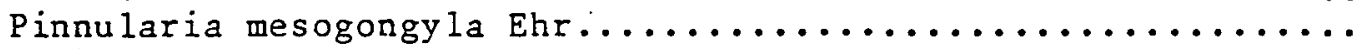

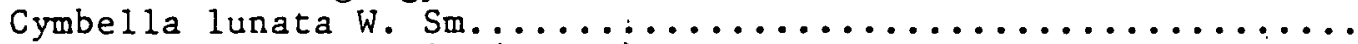

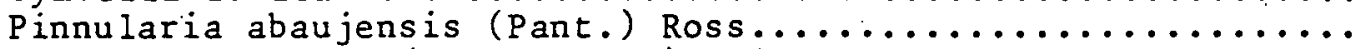

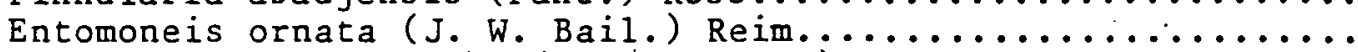

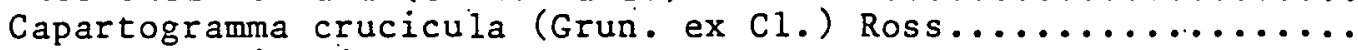

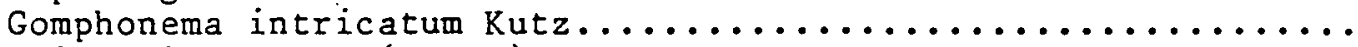

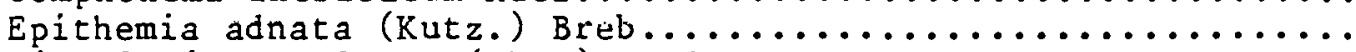

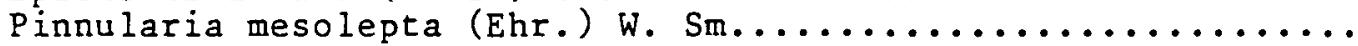

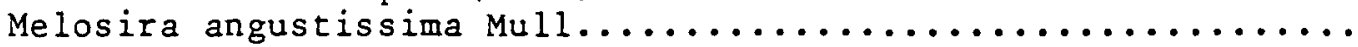

Nitzschia subtilis Kutz...........................

Cymbella naviculiformis. Auersw. ex Heib.

\% OF TOTAL

DIATOM

COUNT

.3382

.3269

.3269

.3156

.3044

.2705

.2705

.2593

. 2480

.2255

.2142

.2142

.2142

.2029

.2029

.2029

.1804

.1691

.1578 .

.1578

.1578

.1465

.1465

.1465

.1353

.1353

.1353

.1127

.1127

.1127

.1015

.0901

.0901

.0901

.0901

.0901

.0901

.0789

.0789

.0789

.0789

.0789

.0676

.0676

.0563

.0563

.0563

.0563

.0563

.0450 
SPECIES

FREQUENCY

RATING

101

102

103

104

105

106

107

108

109

110

111

112

113

114

115

116

117

118

119

120

121

122

123

124

125

126

127

128

129

130

131

1.32

133

134

135

136

137

138

139

140

141

142

143

144

145

146

147

148

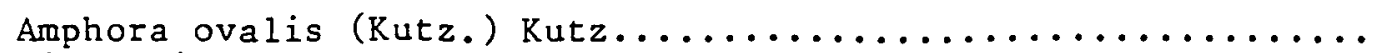

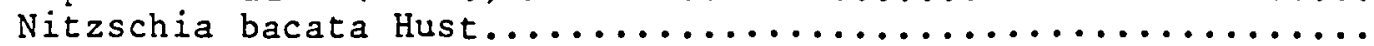

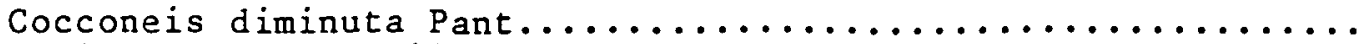

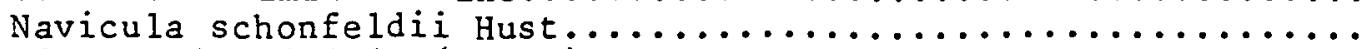

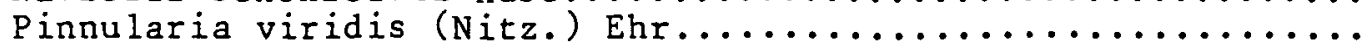

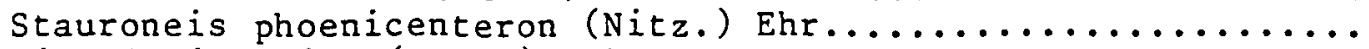

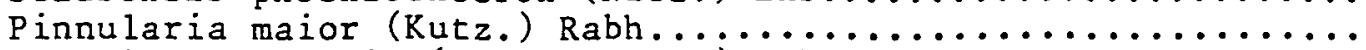

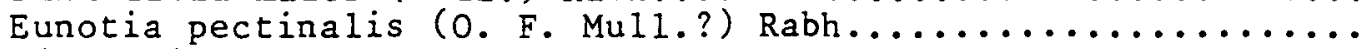

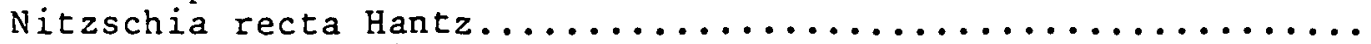

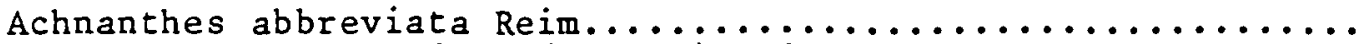

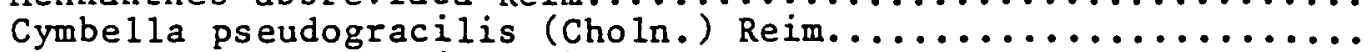

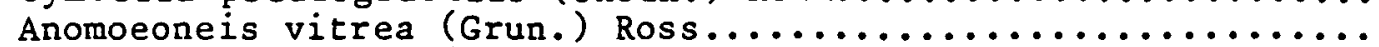

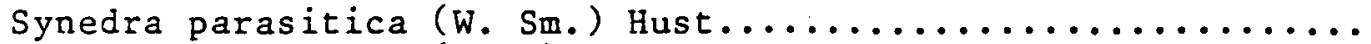

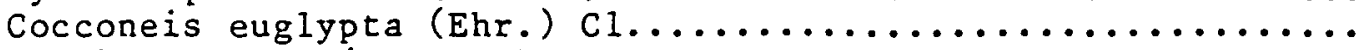

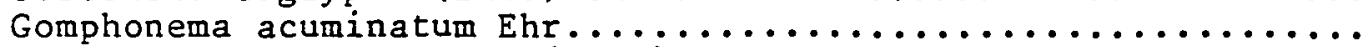

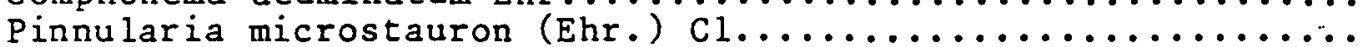

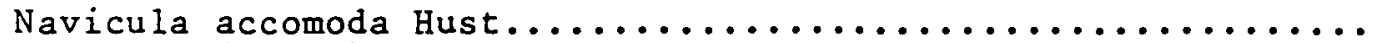

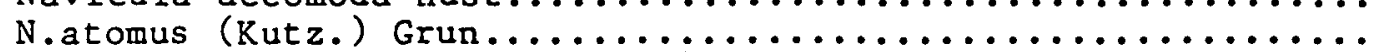

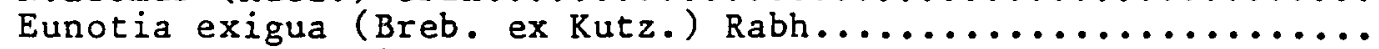

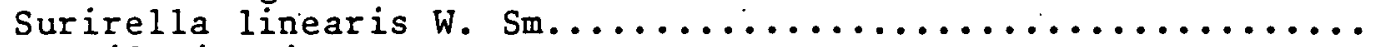

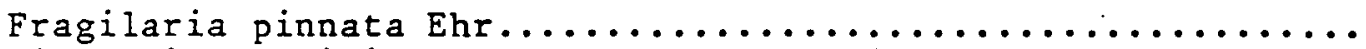

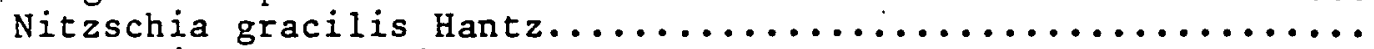

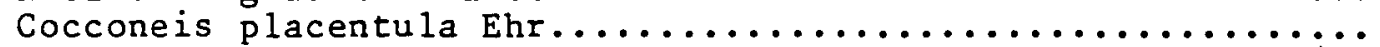

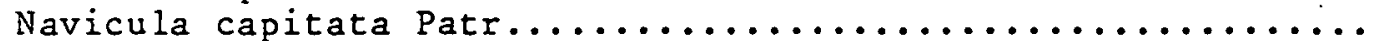

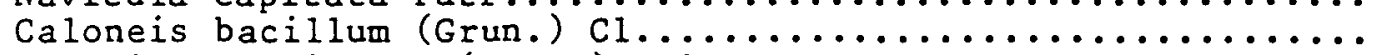

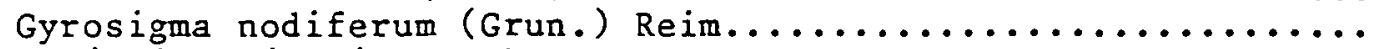

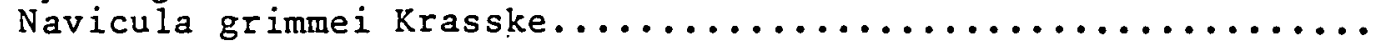

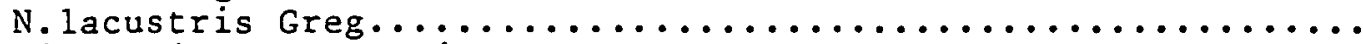

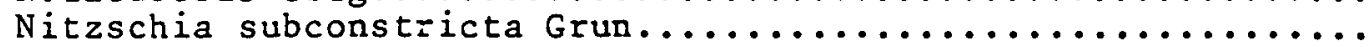

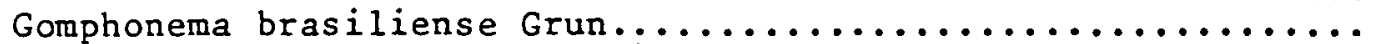

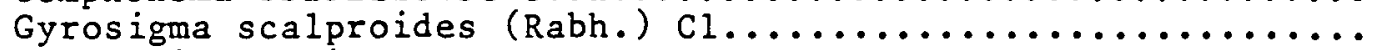

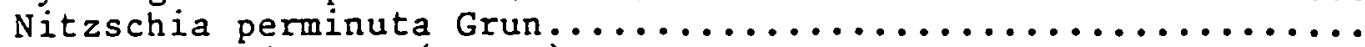

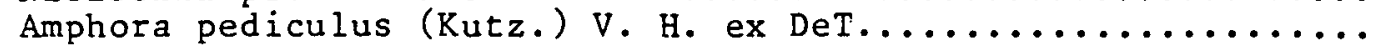

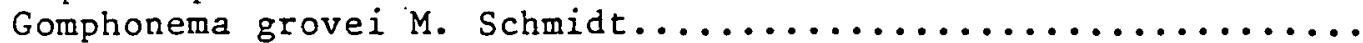

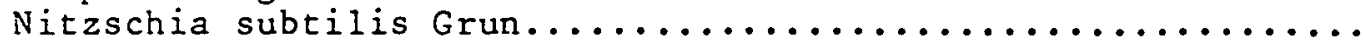

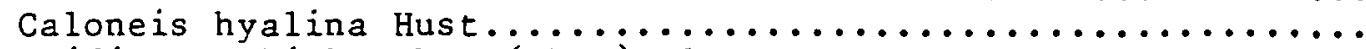

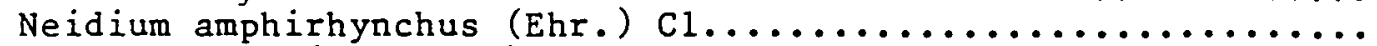

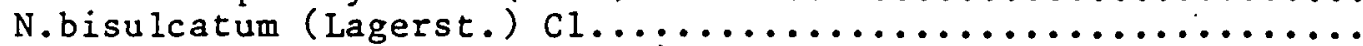

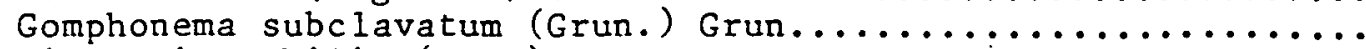

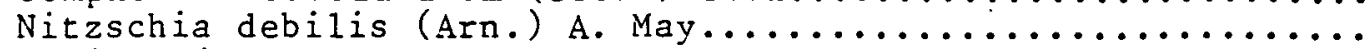

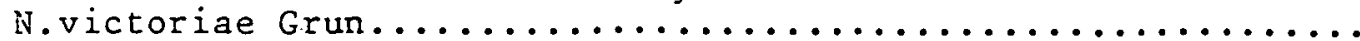

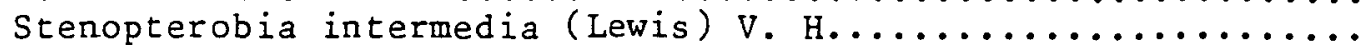

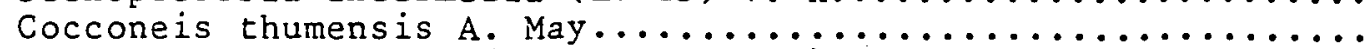

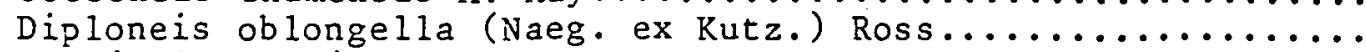

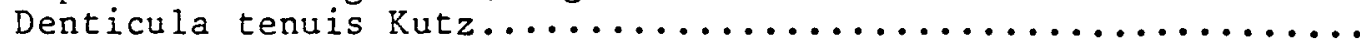

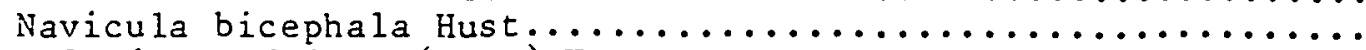

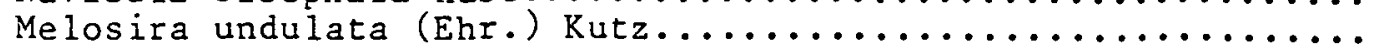

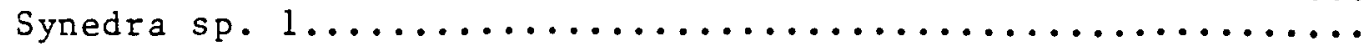

$\%$ OF TOTAL

DIATOM

COUNT

.0450

.0450

.0450

.0450

.0450

.0450

.0450

.0338

.0338

.0338

.0338

.0338

.0338

.0338

.0338

.0225

.0225

.0225

.0225

.0225

.0225

.0225

.0225

.0225

.0112

.0112

.0112

.0112

.0112

.0112

.0112

.0112

.0112

.0112

.0112

.0112

.0112

.0112

.0112

.0112

.0112

.0112

.0112

.0112

.0112

.0112

.0112

.0112 


\section{B.4. Savannah River Water Chemistry Summary}

The water chemistry data may be formated separately from, or in combination with, the biological data. Figures B.4.1-B.4.23 show one type of independent format. In these figures, the water chemistry data are plotted by station for each parameter over the entire survey period. This type of format may be used to look for long-term trends or unusual station values.

Cross formatting between water chemistry data and biological data may be used for a variety of purposes. One type of format lists the chemical ranges encountered for each survey organism. For example, the diatom species Gomphonema parvulum was found in the following chemical ranges:*

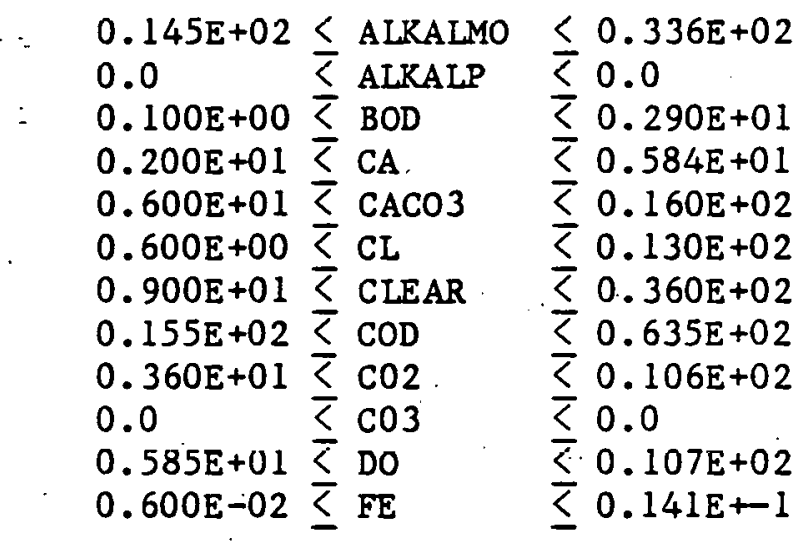

* Chemical abbreviations are identified in Chapter VIII.D. 


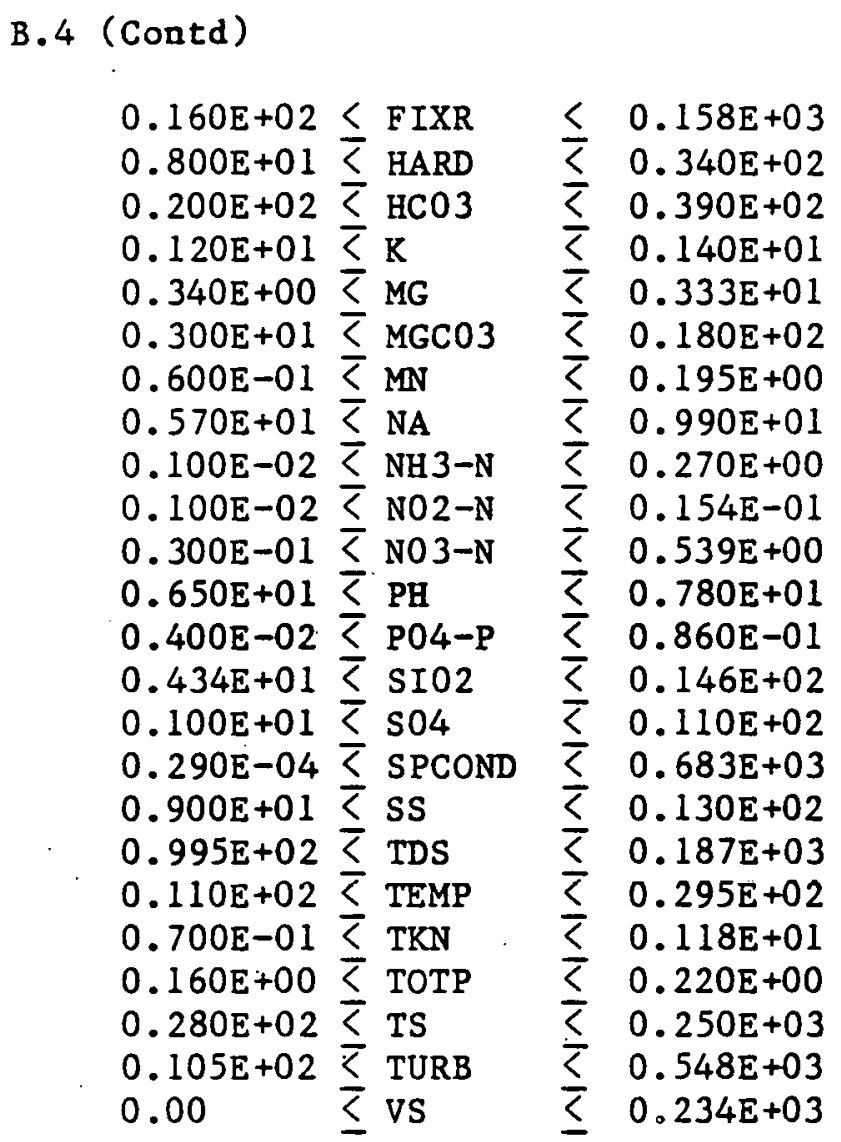




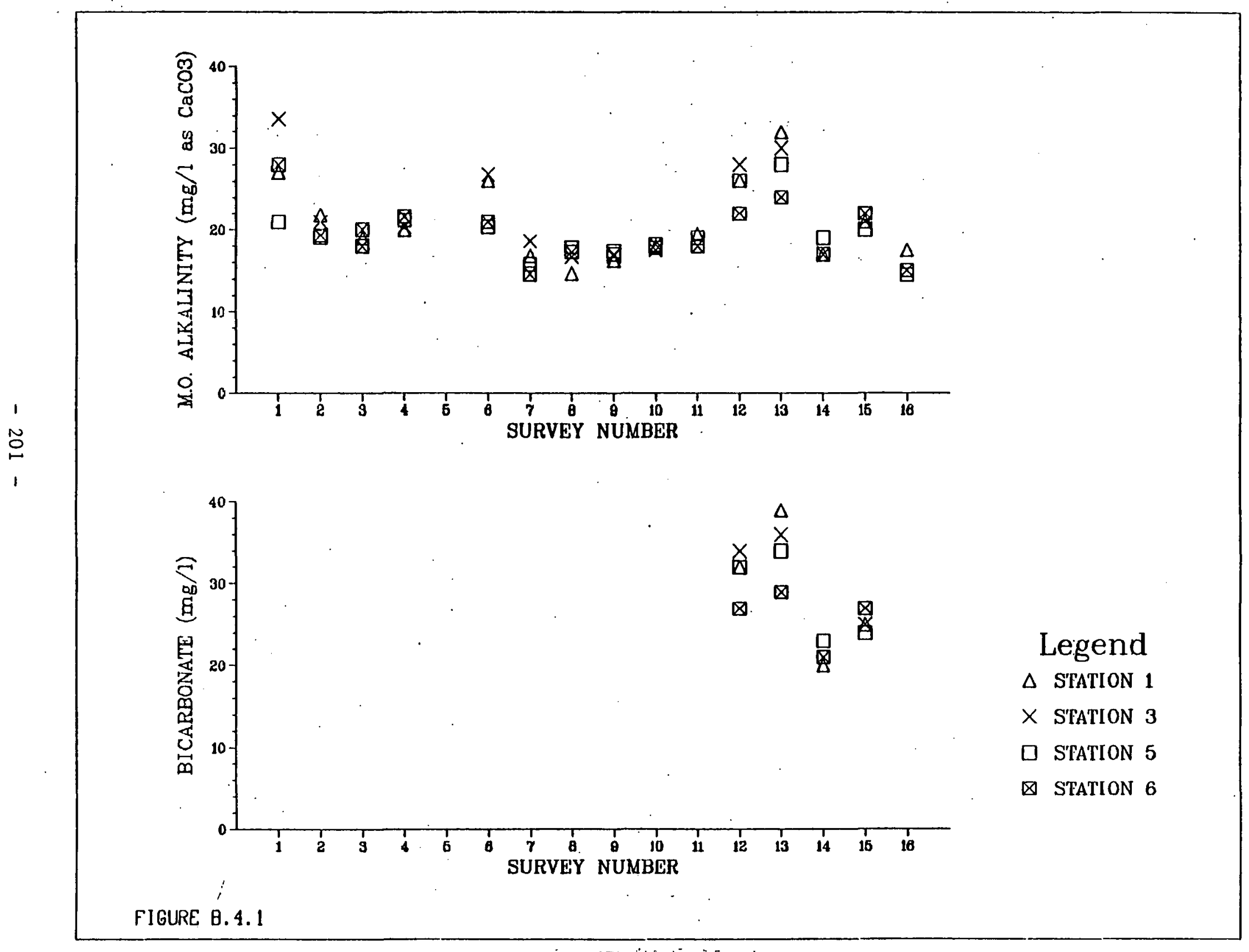




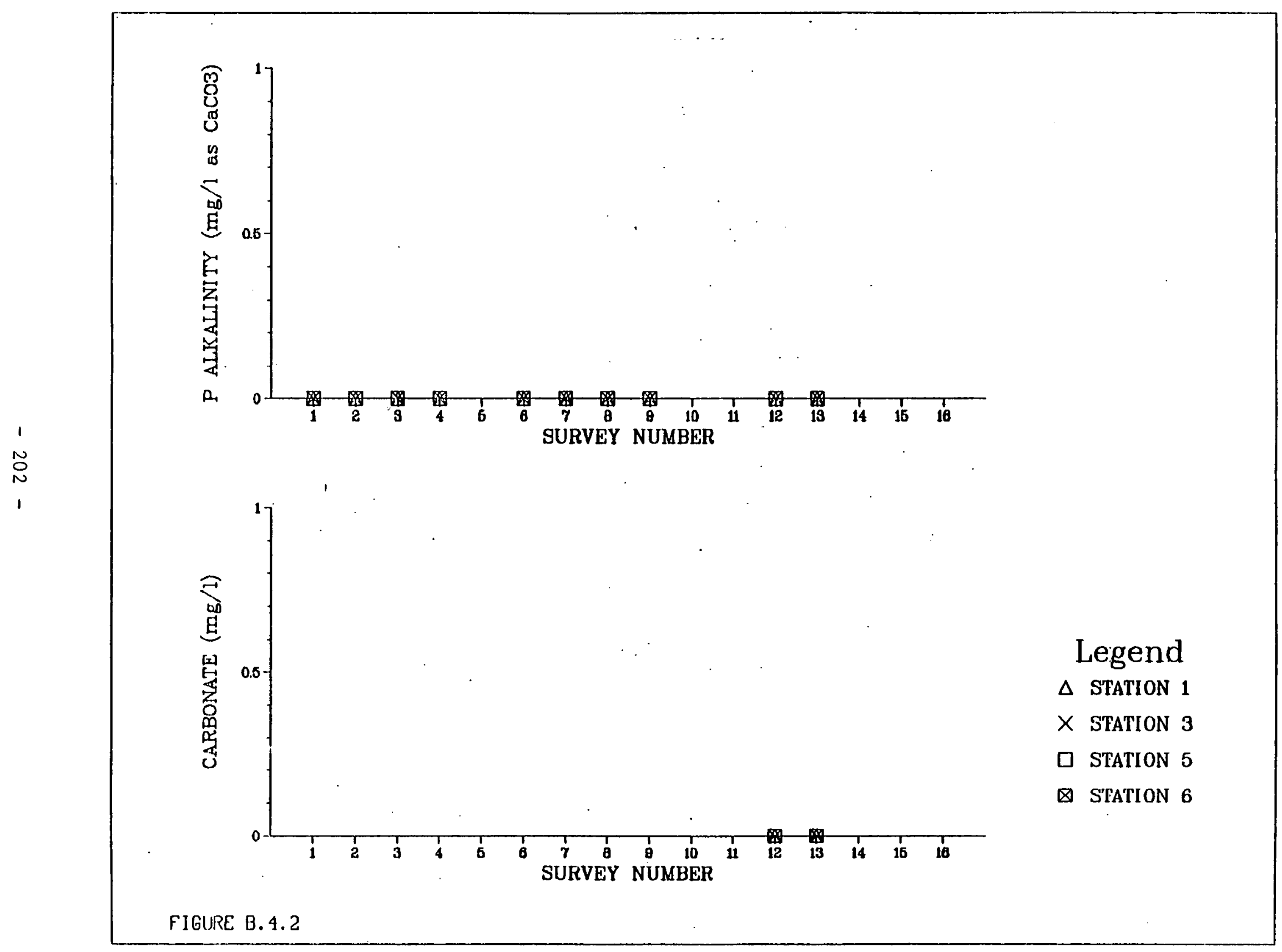

FIGURE B. 4.2 


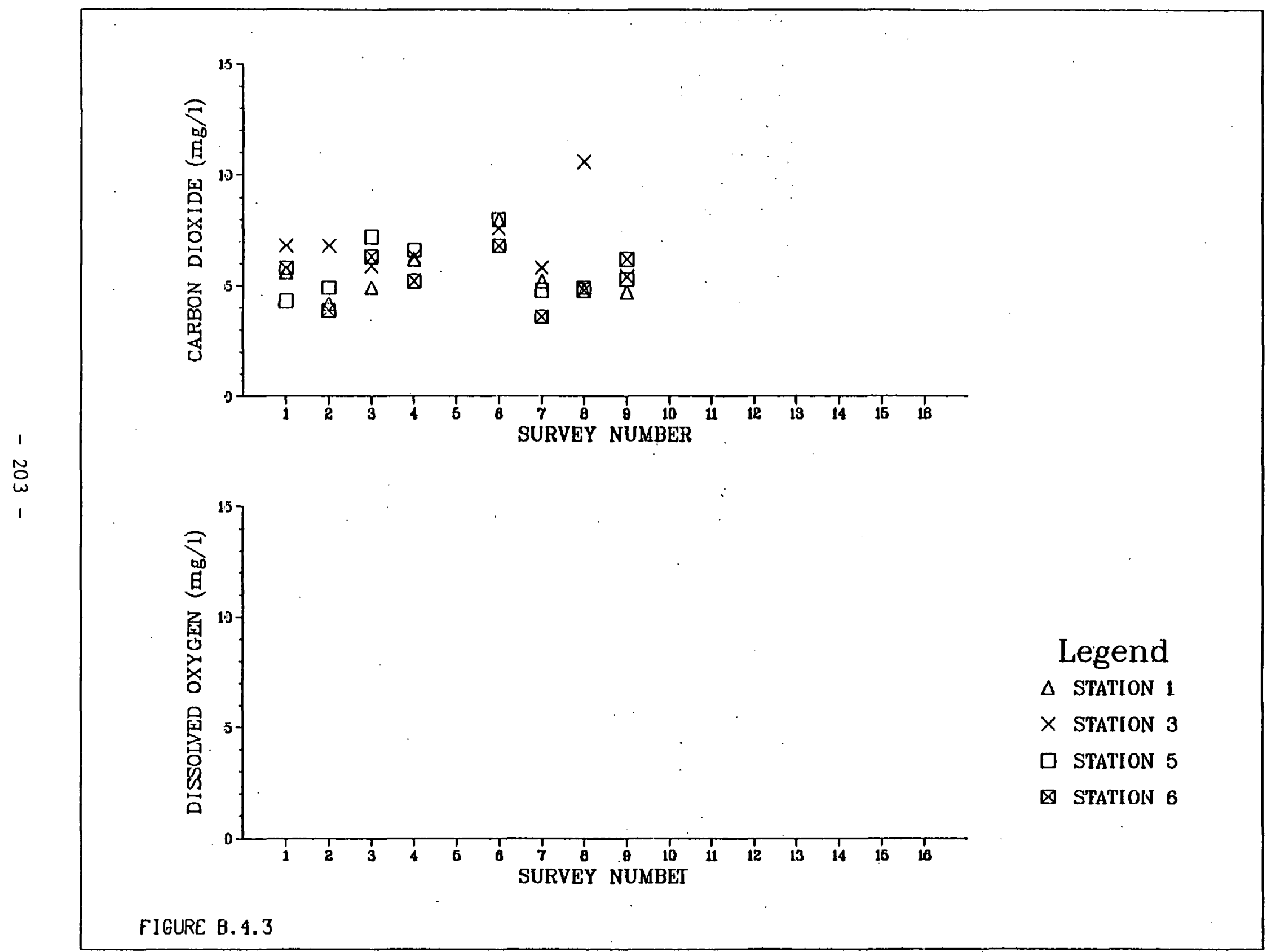




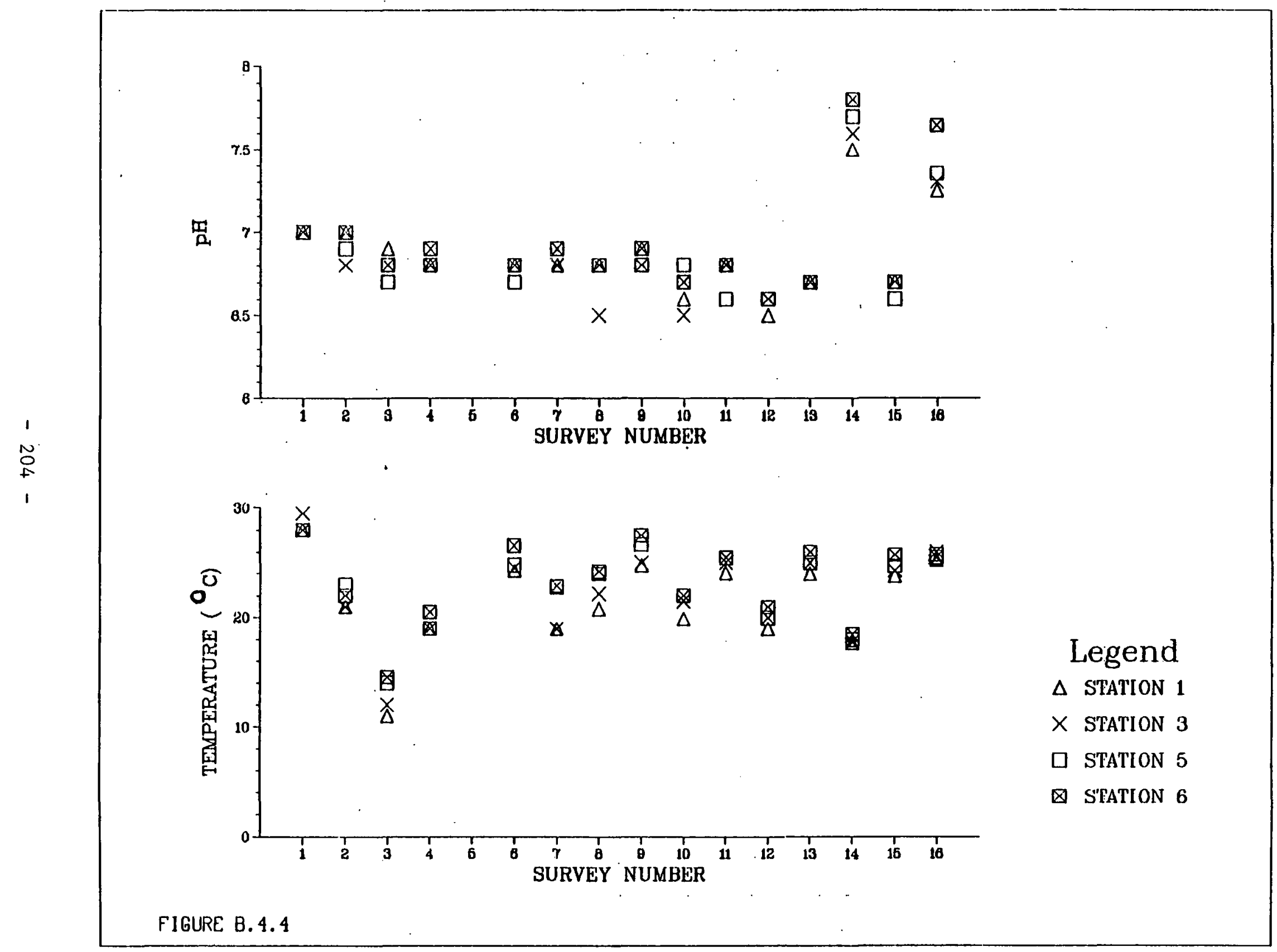




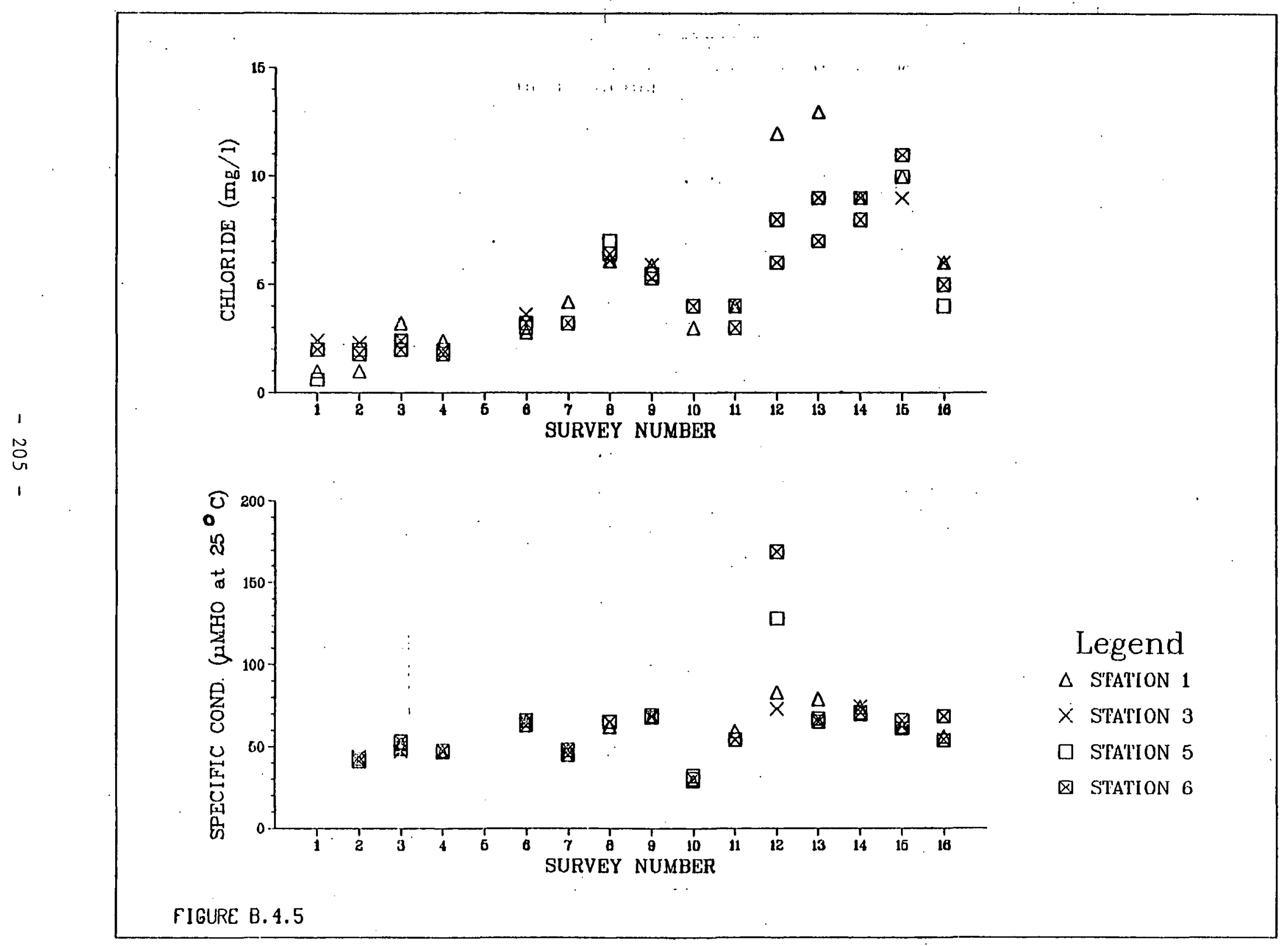




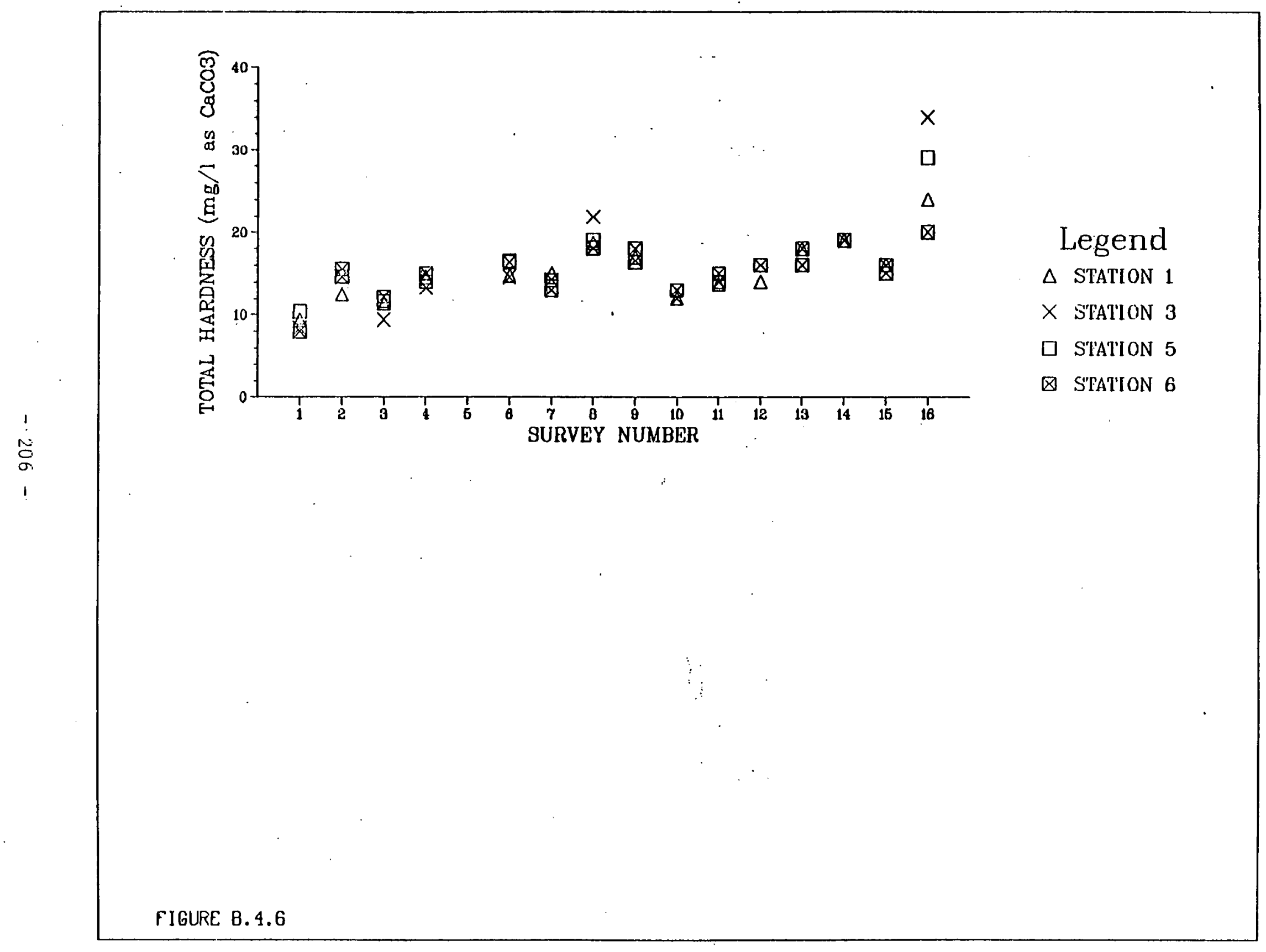




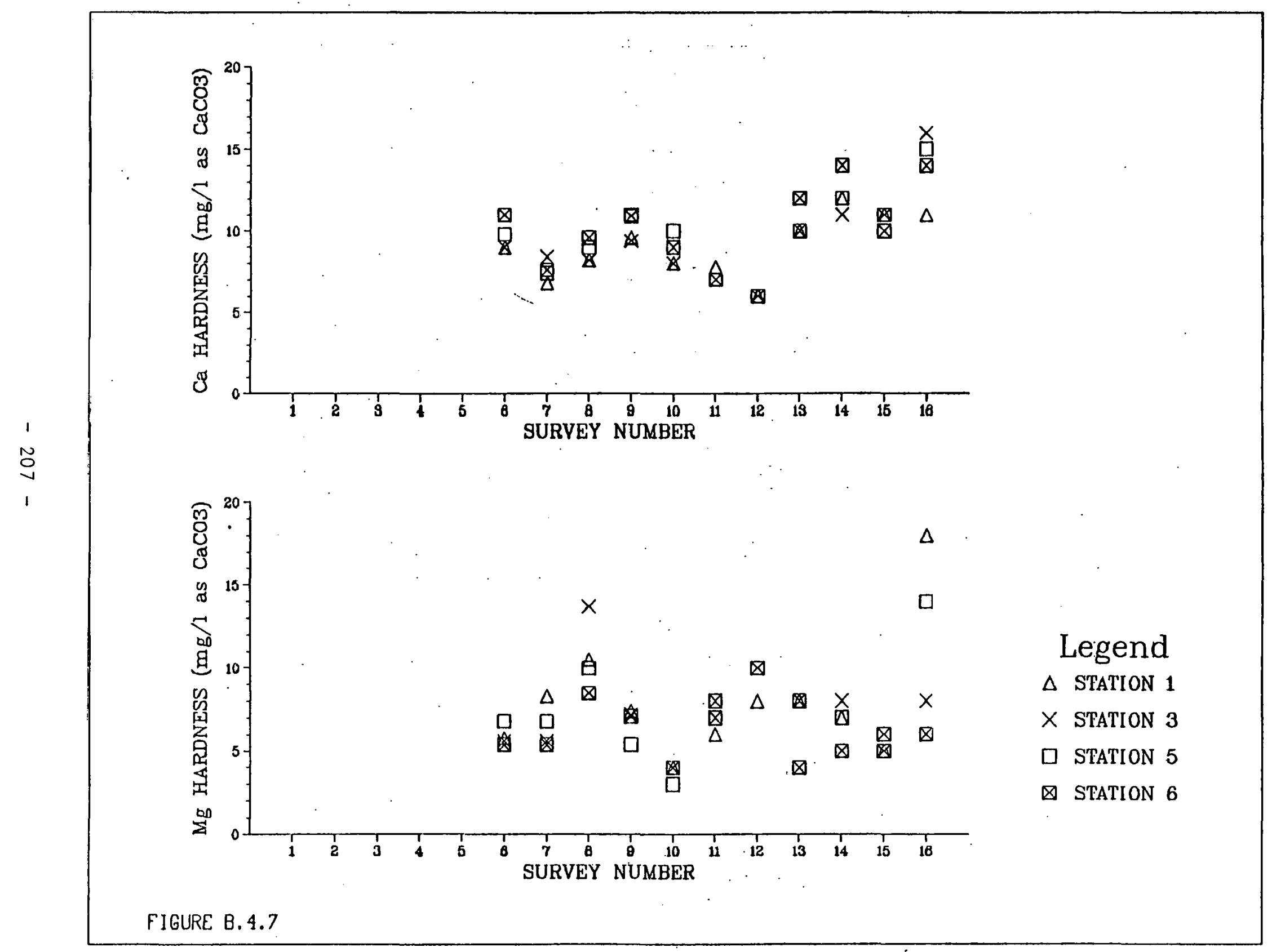




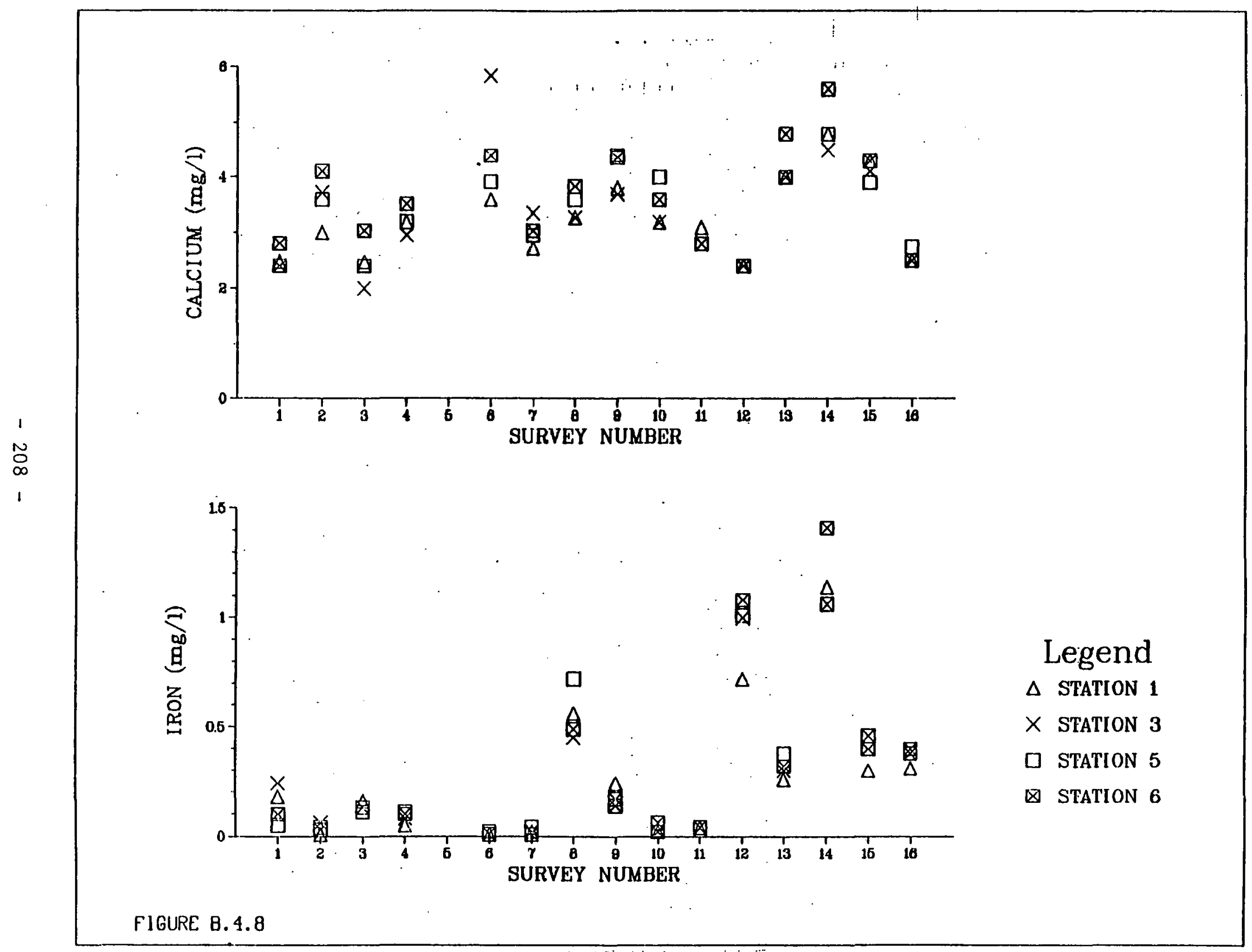




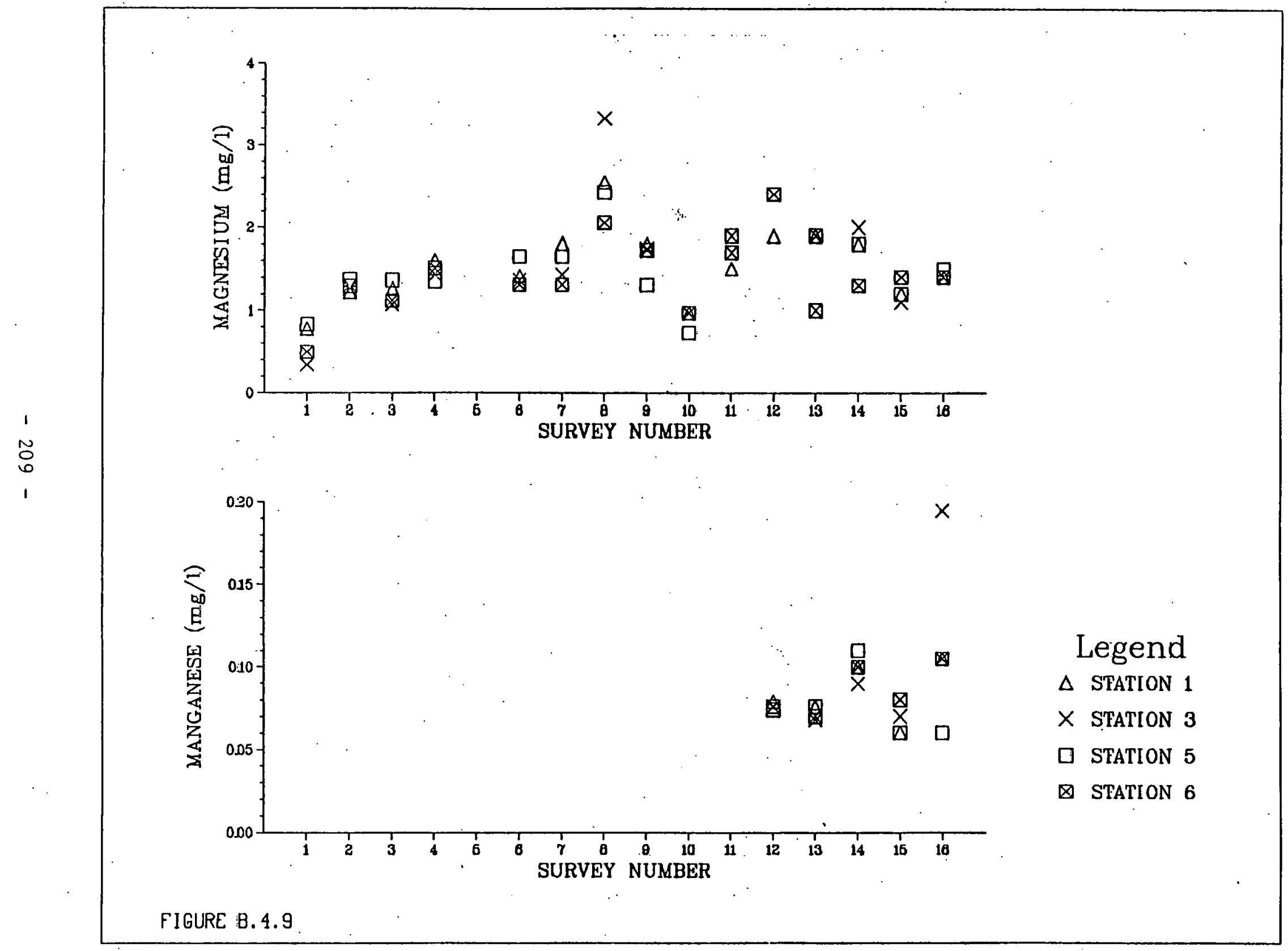




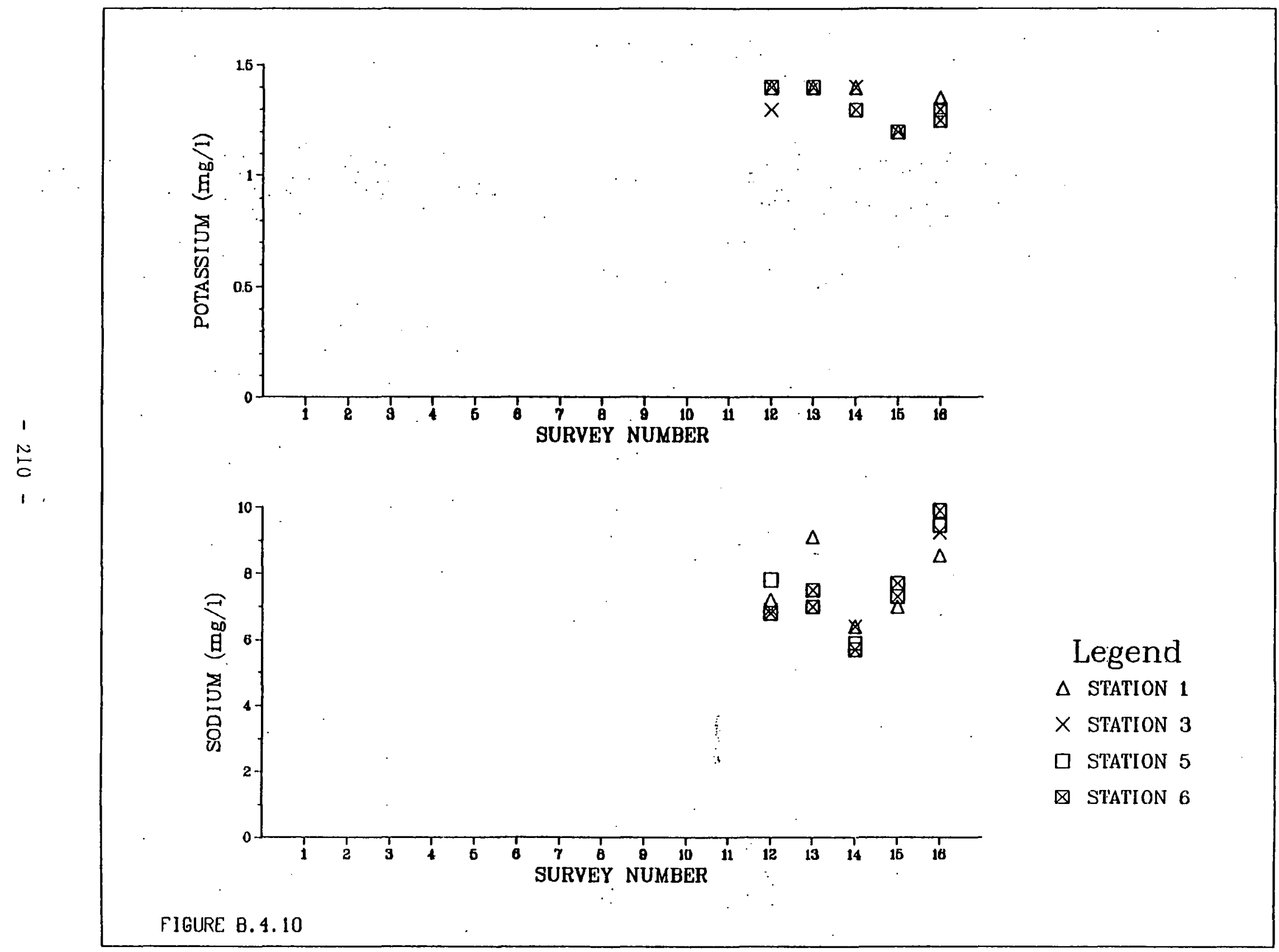




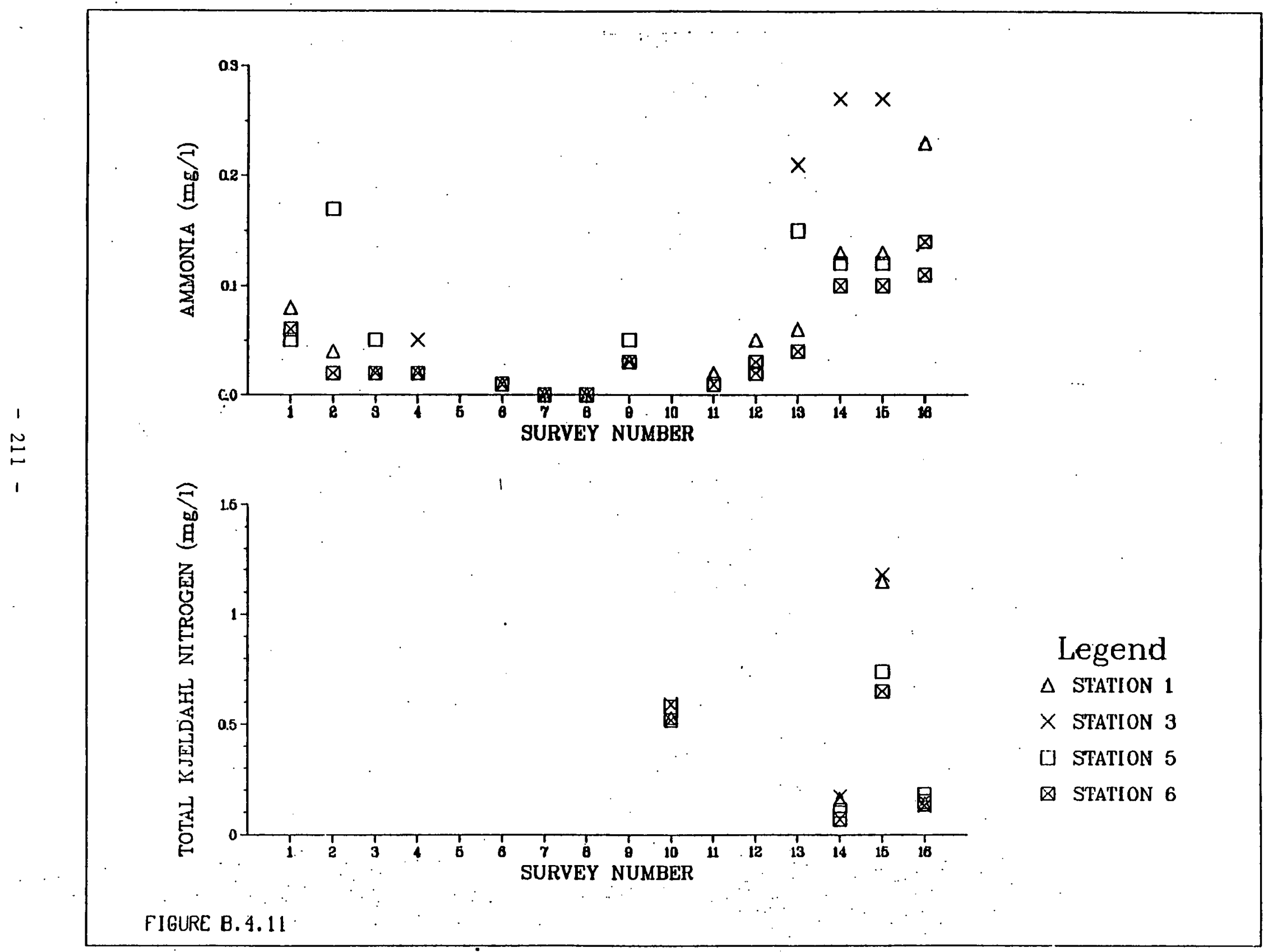



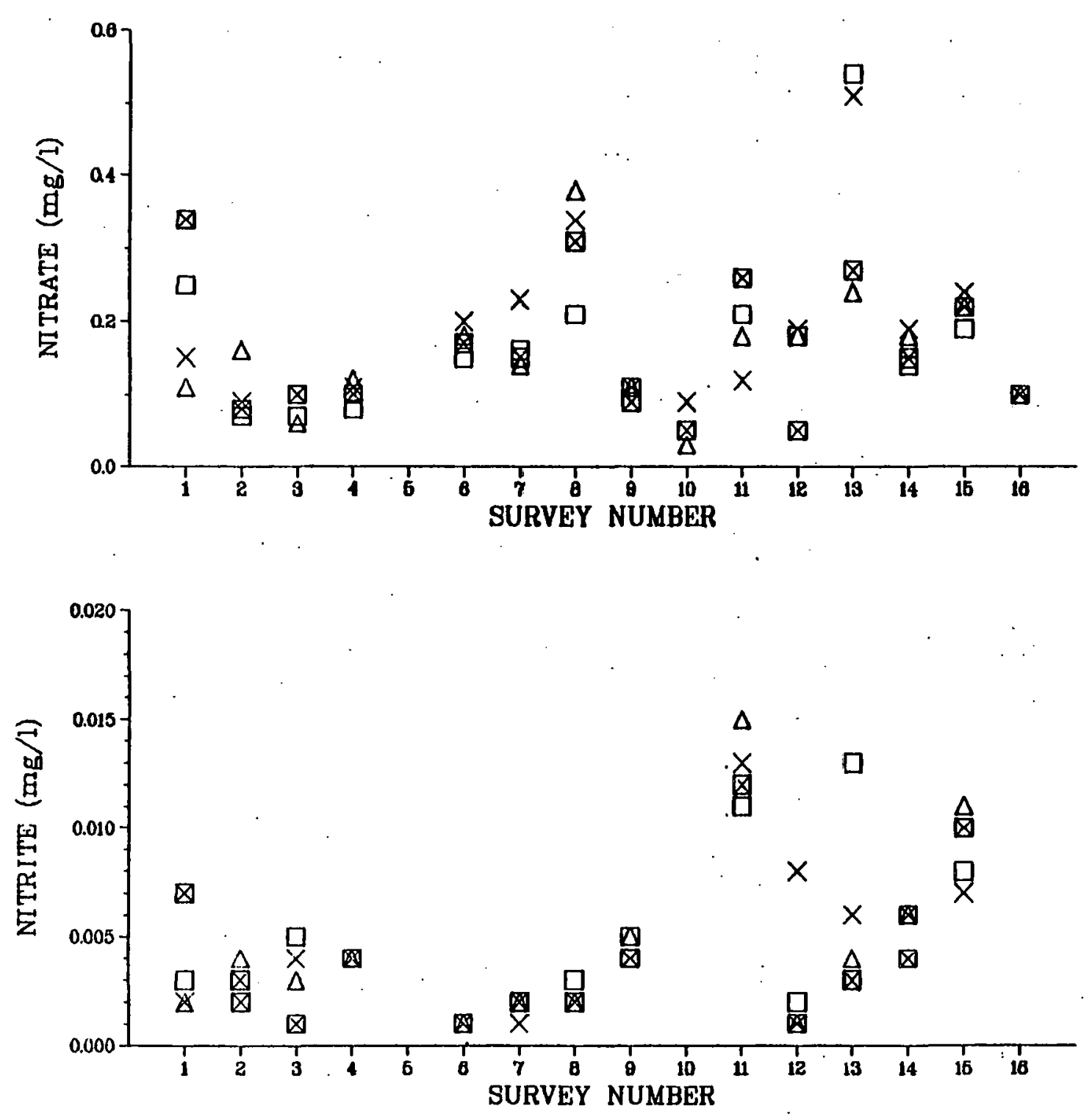

Legend $\triangle$ STATION 1 $\times$ STATION 3

口 STATION 5

$\otimes$ STATION 6 


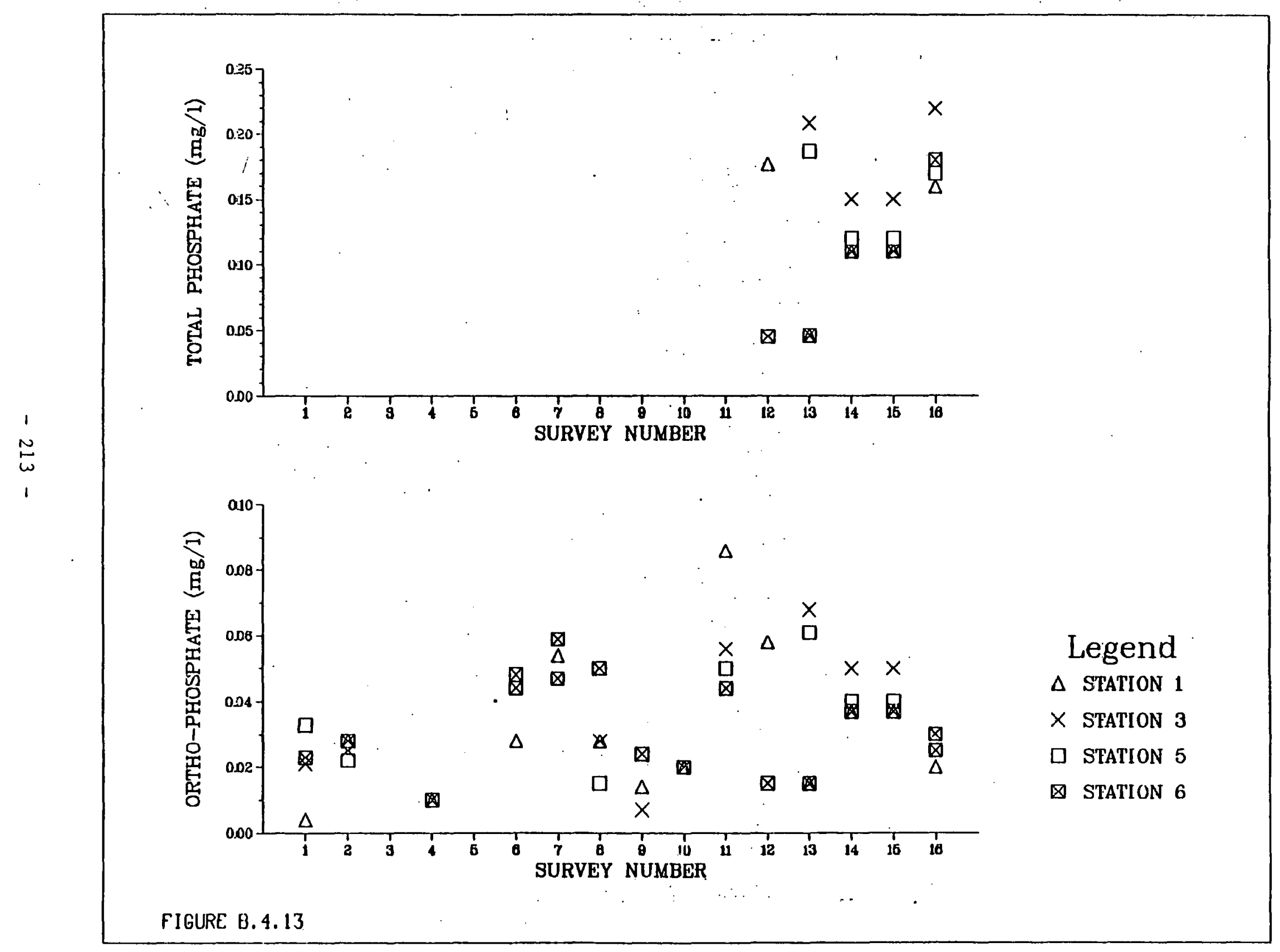




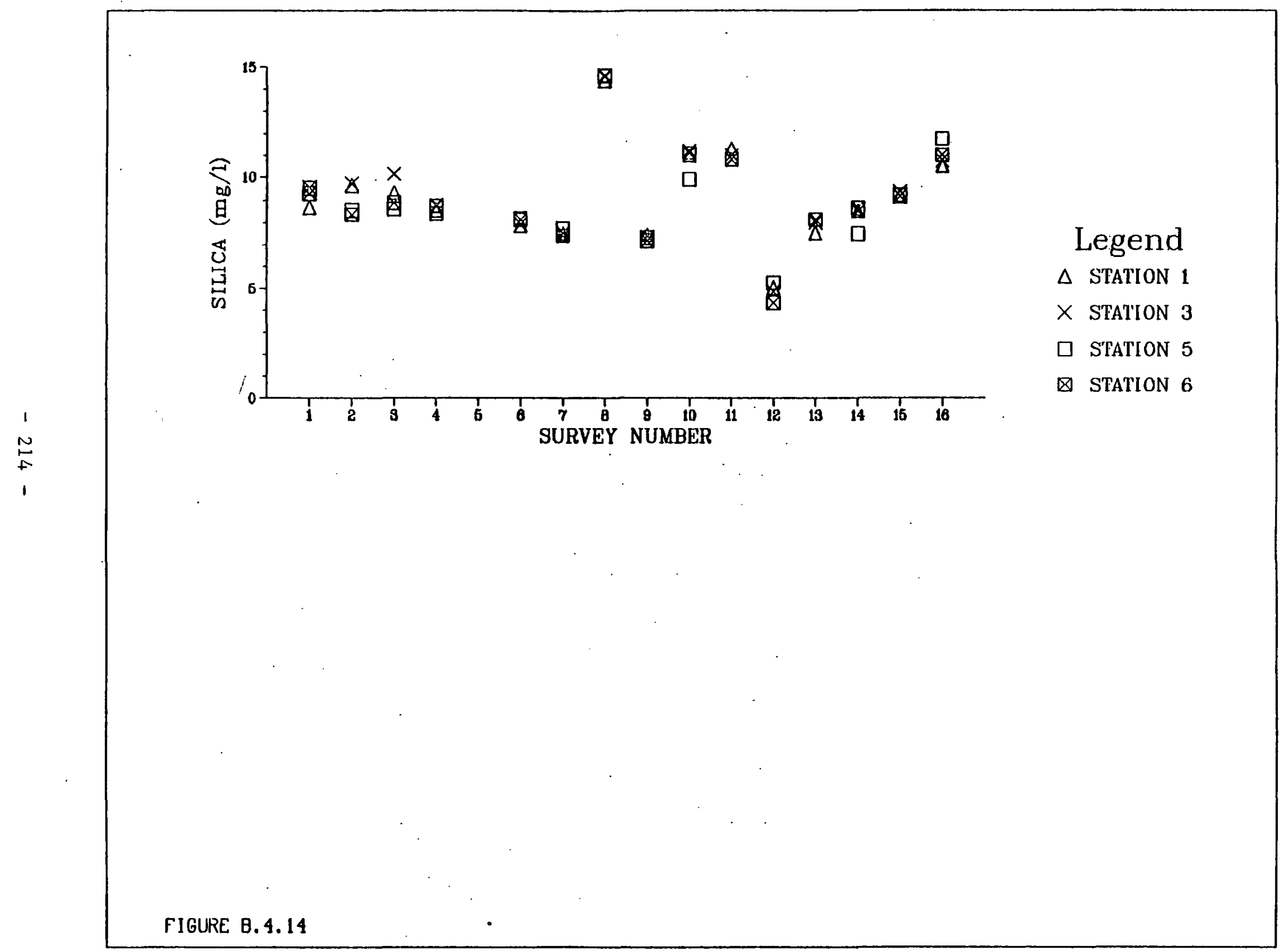

FIGURE B.4.14 


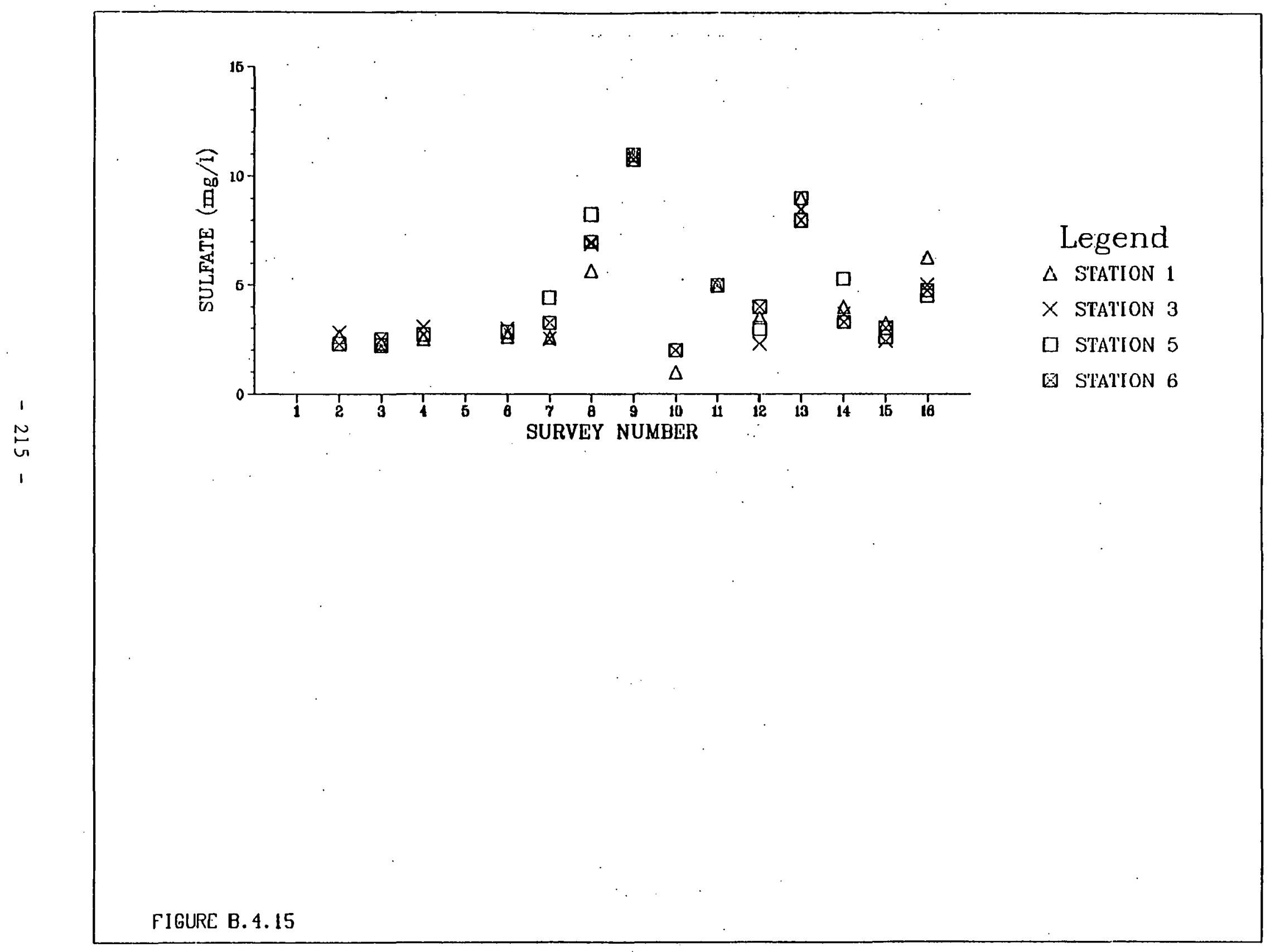




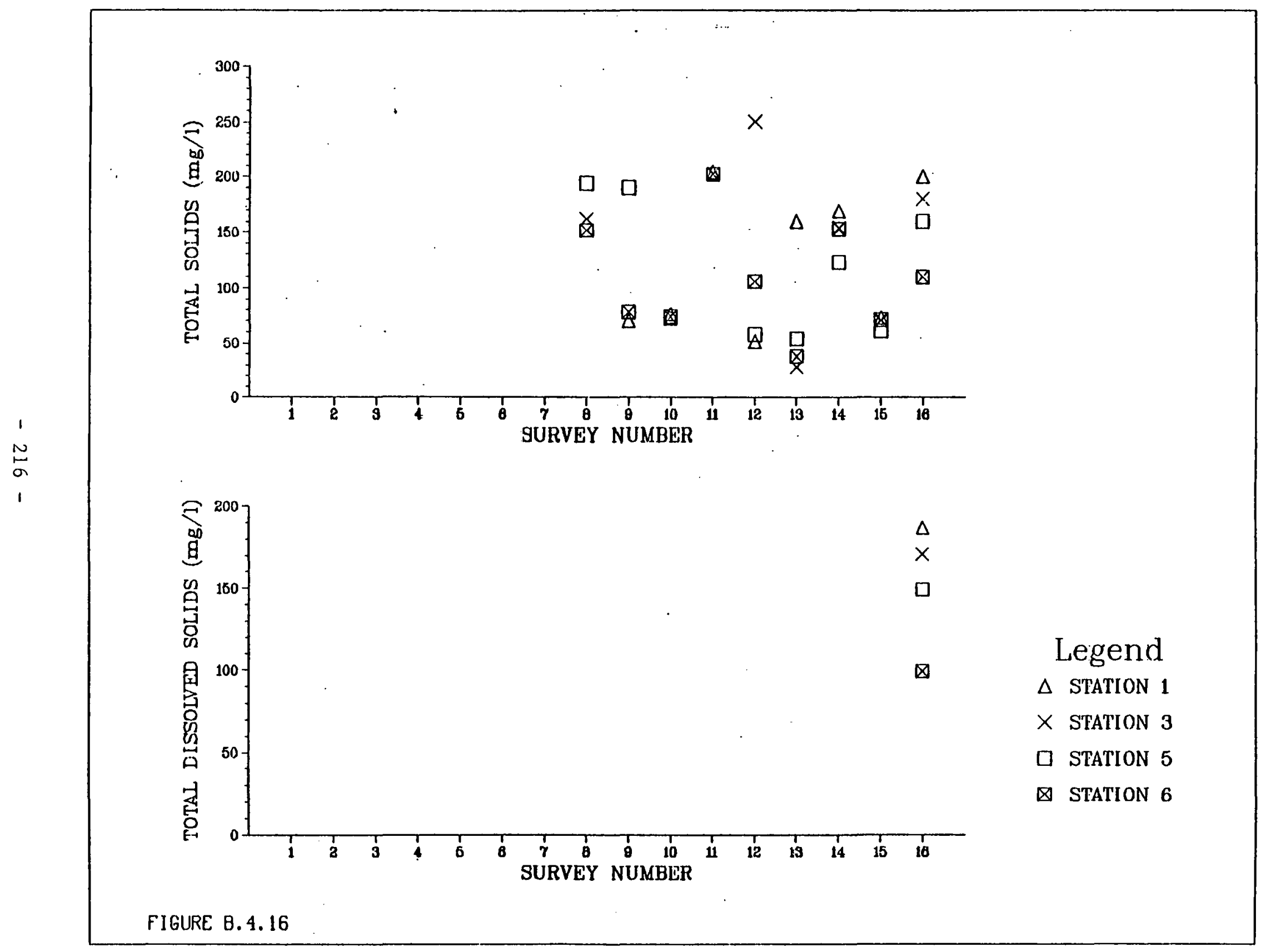




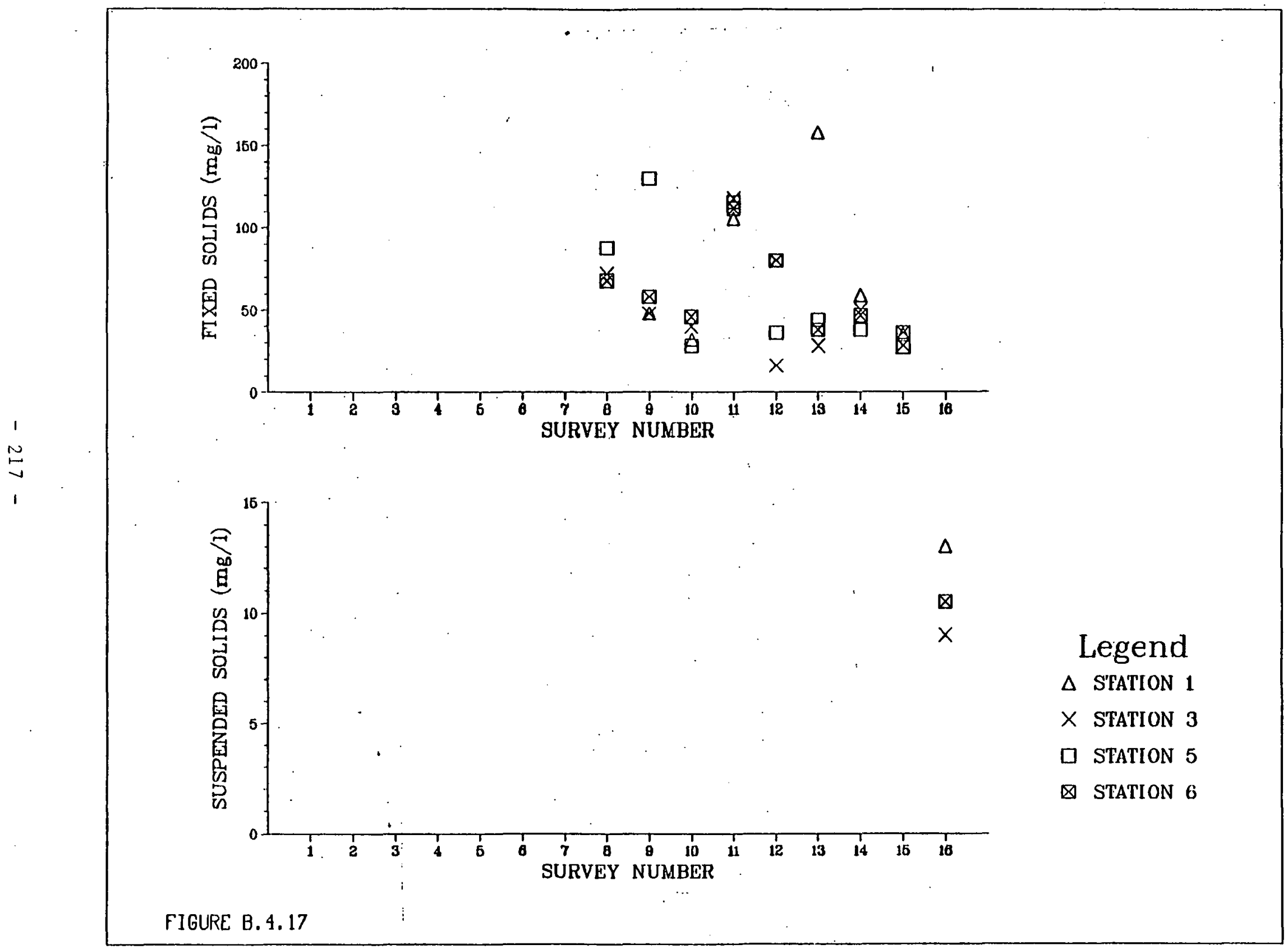




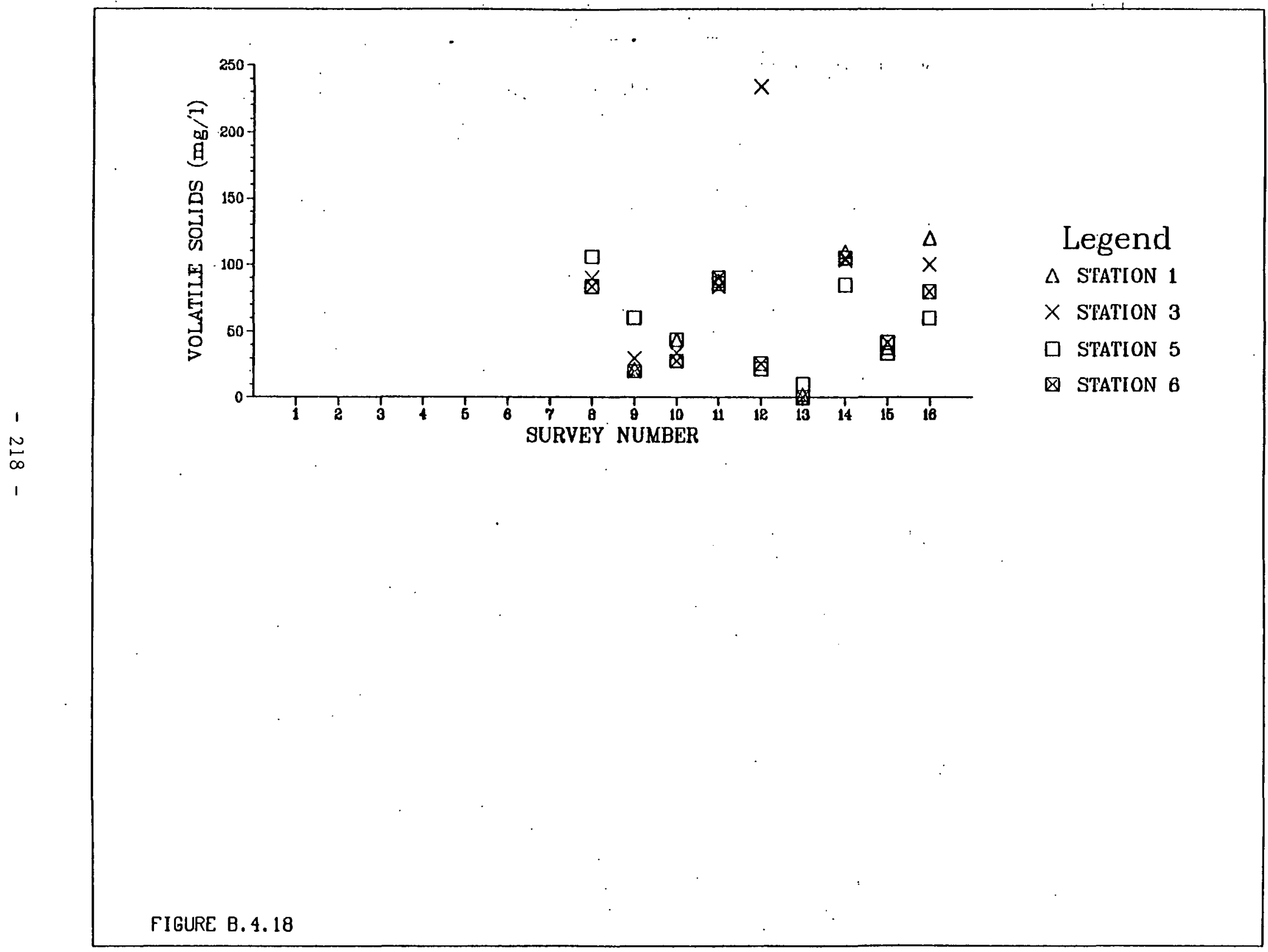




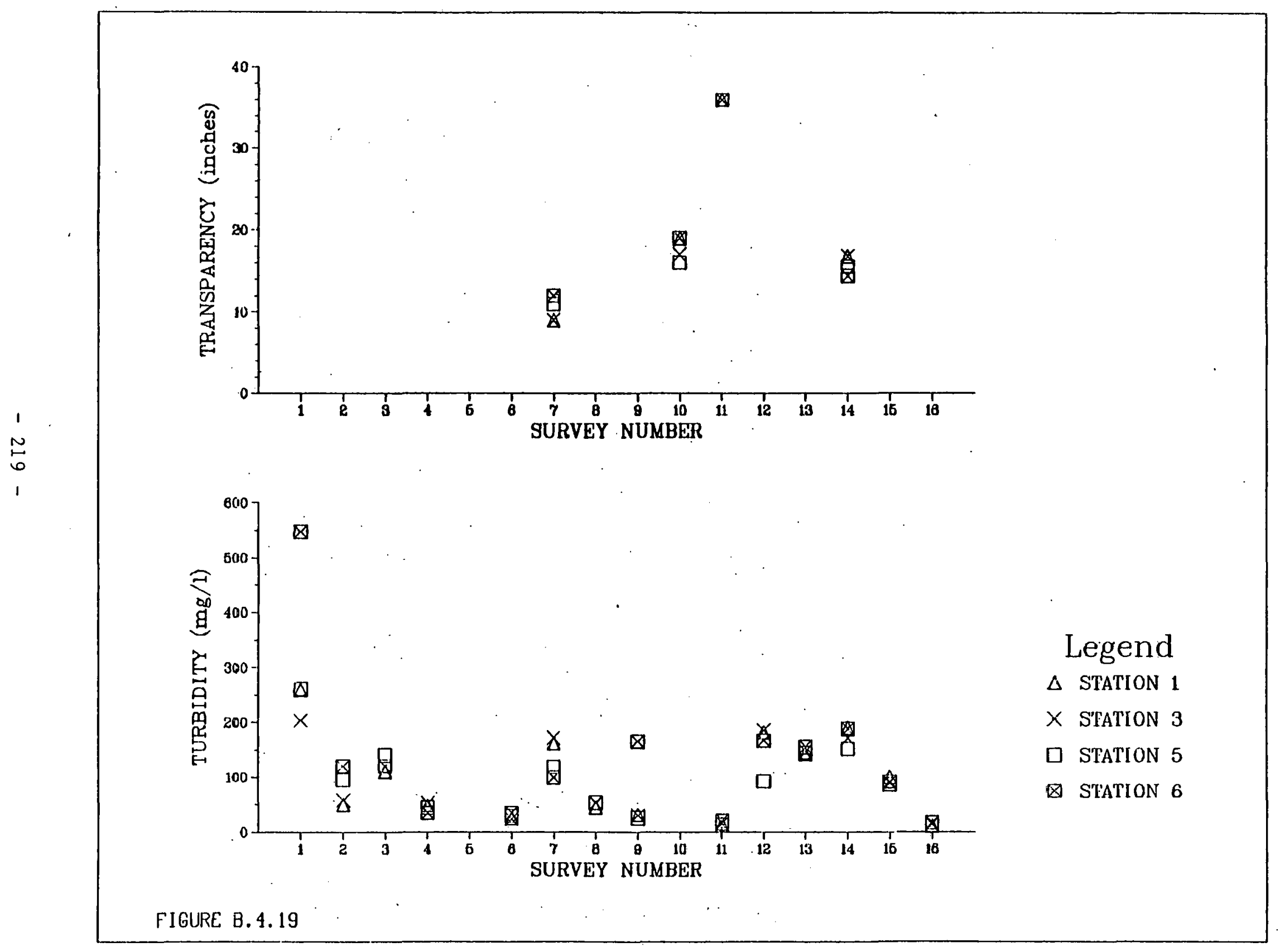




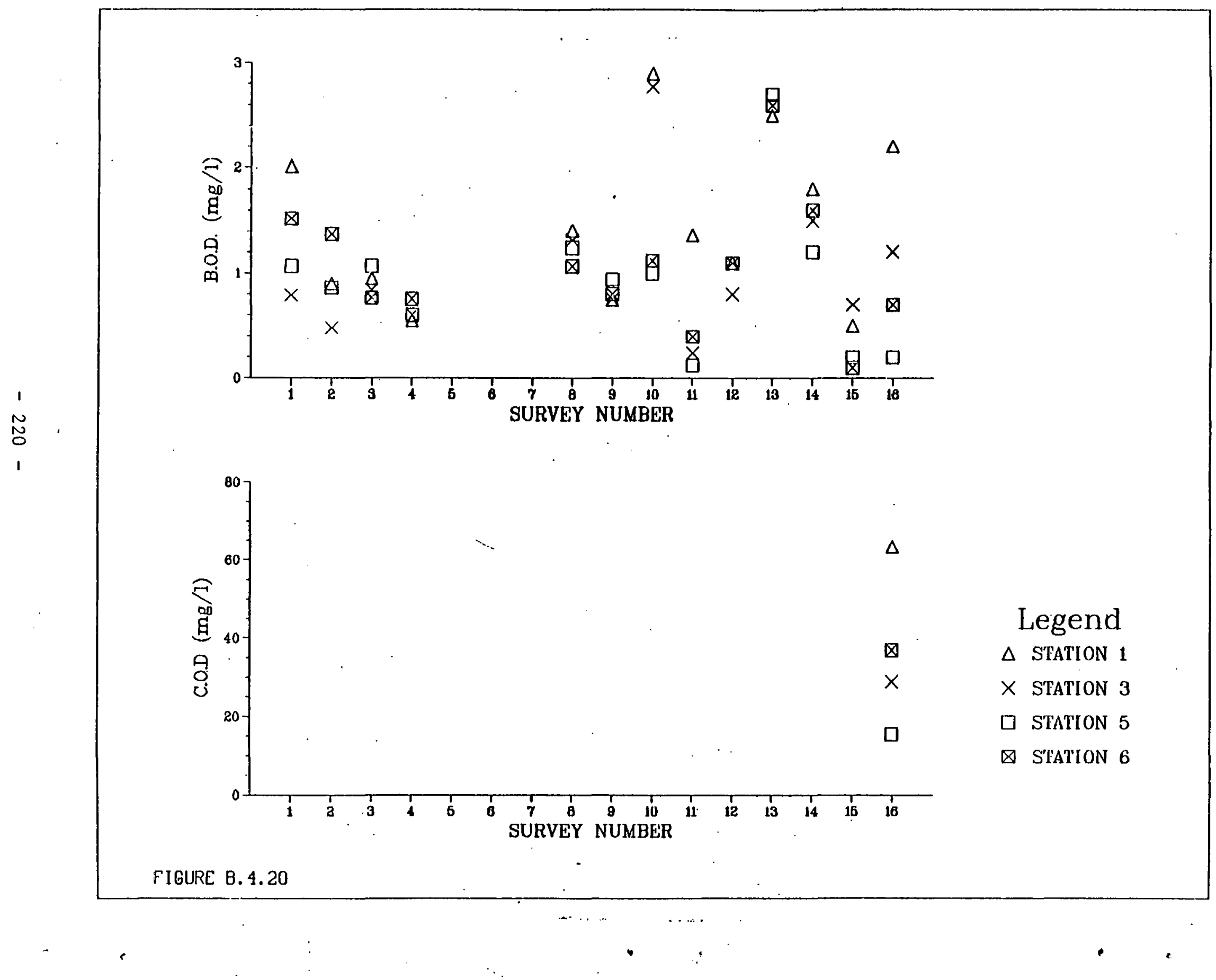




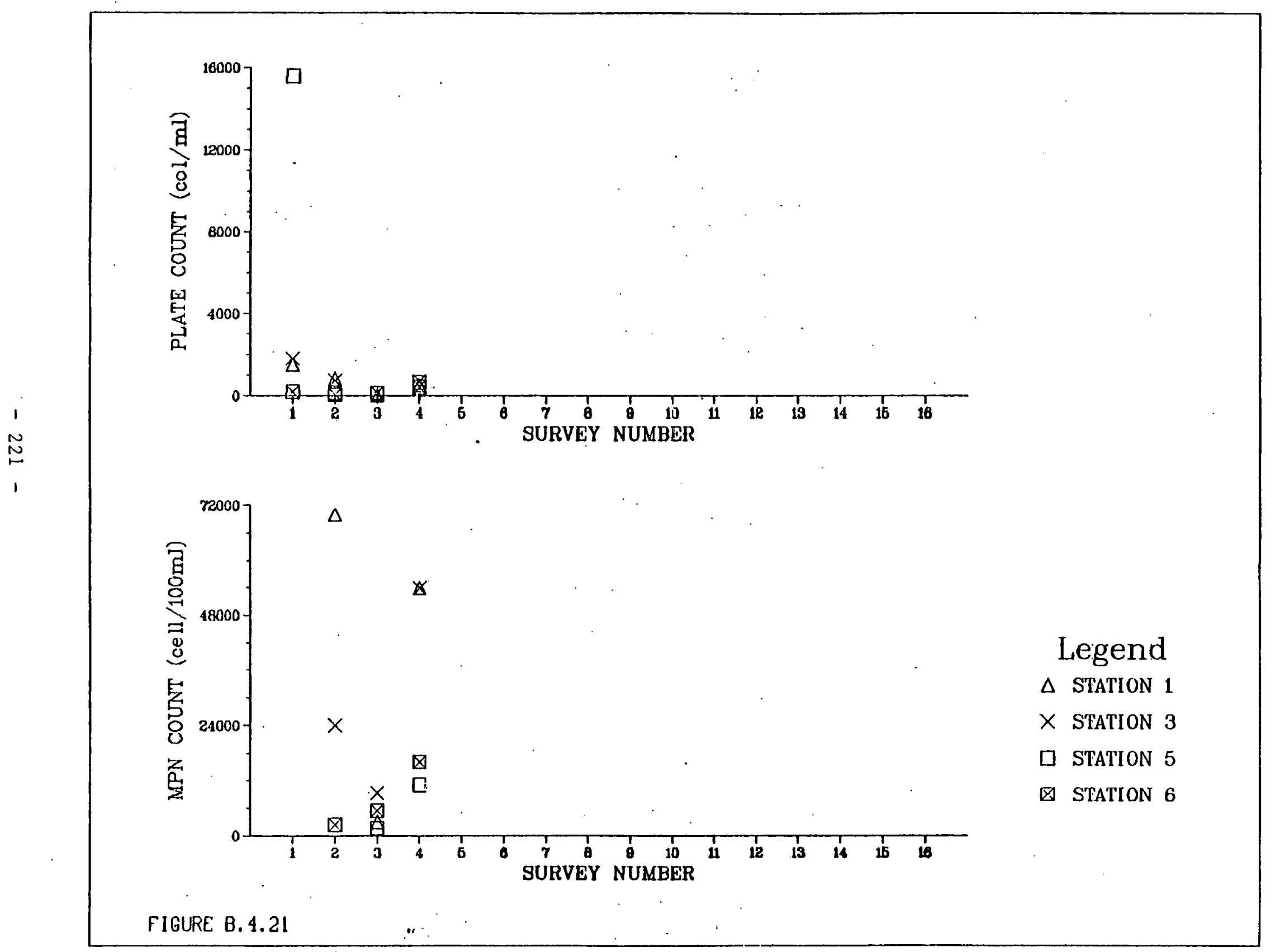




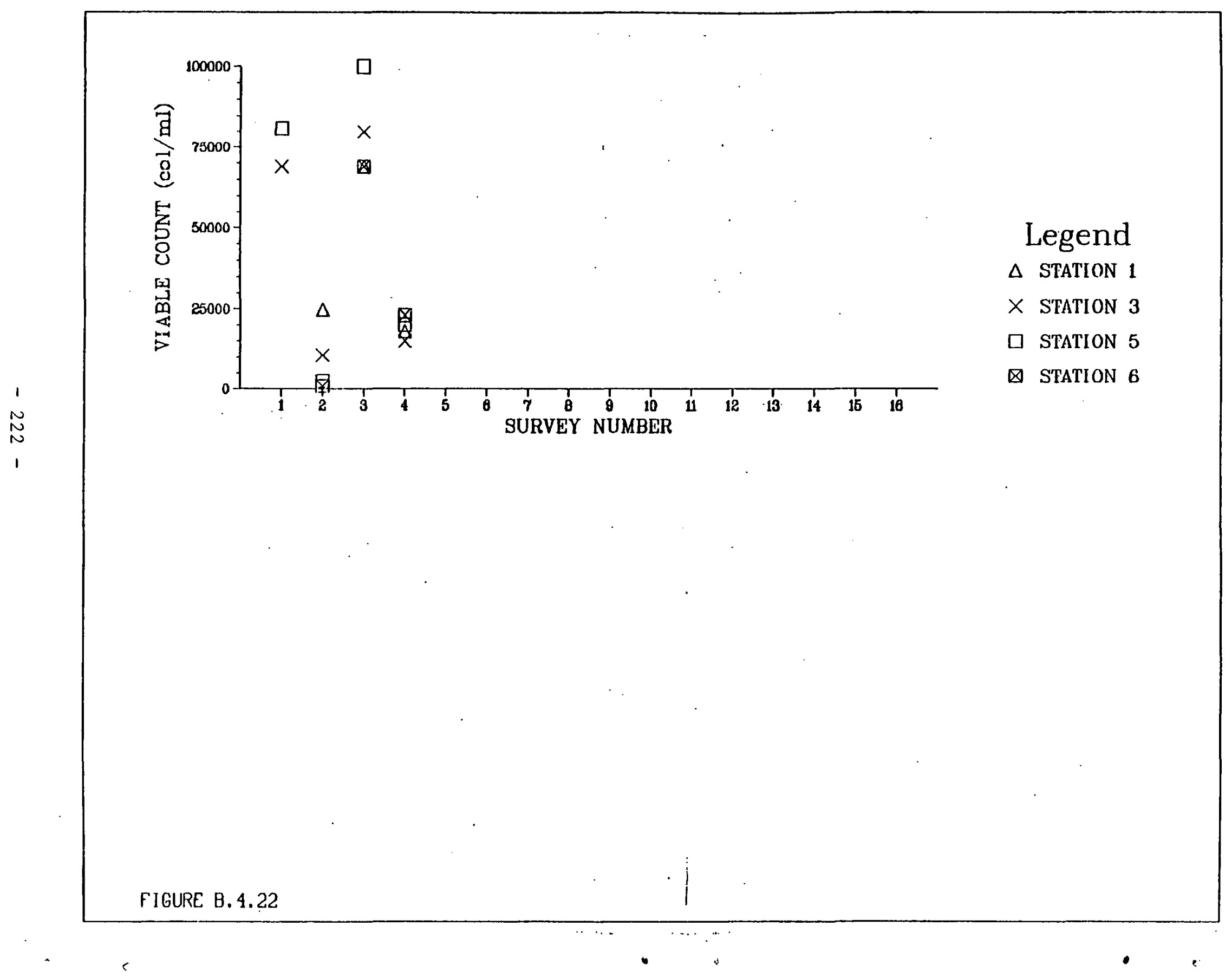




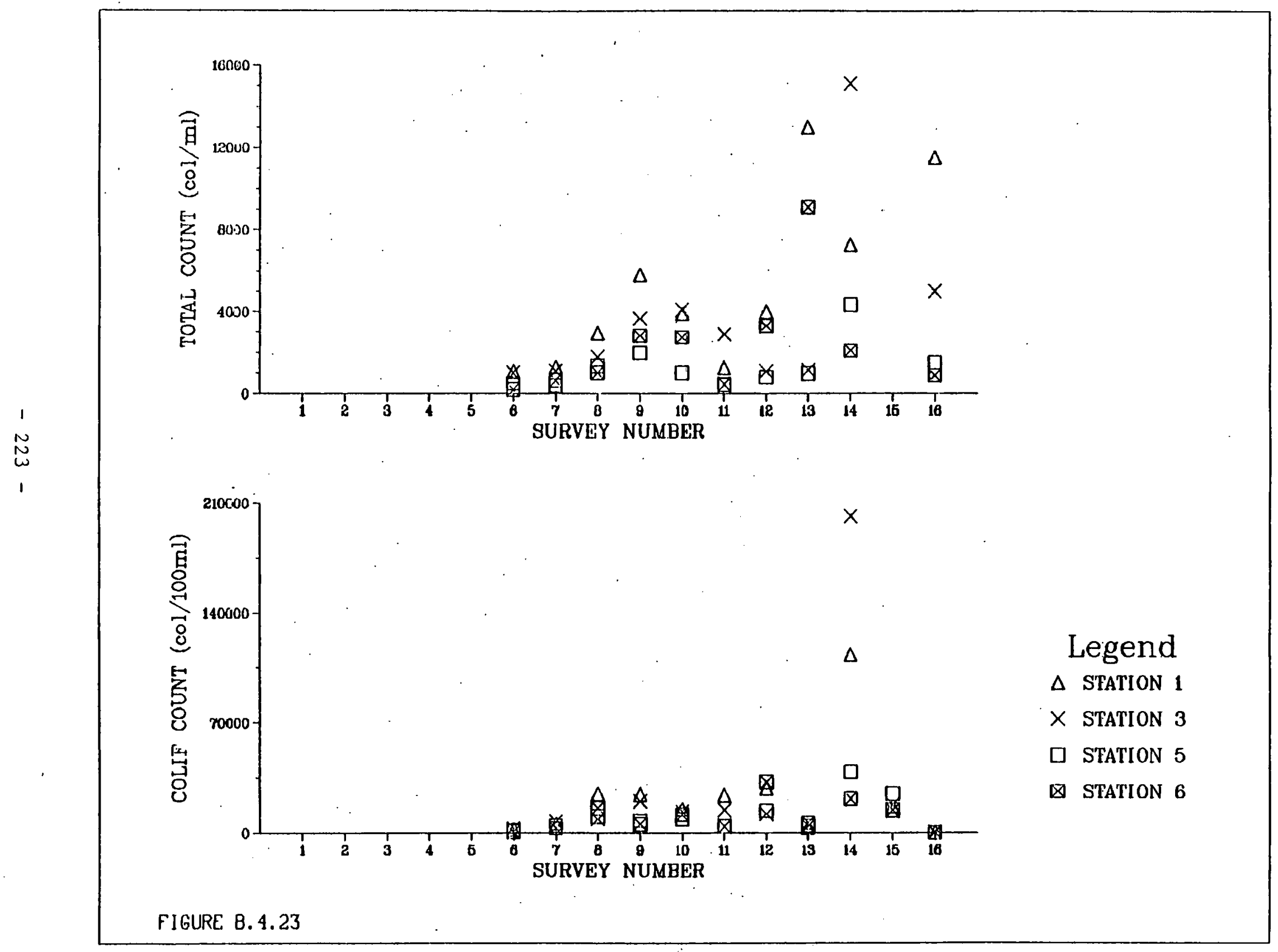


Appendix C. Savannah River Flow and Temperature Data

C.1 Savannah River Flow and Temperature Data at Augusta (A) or Jackson $(J)$.

C.2 Savannah River Daily Flow at Augusta during the Academy of Natural Sciences of Philadelphia Surveys. 
Appendix C.I. Savannah River Flov and Temperature Data at Augusta (A) or Jackson (J)*

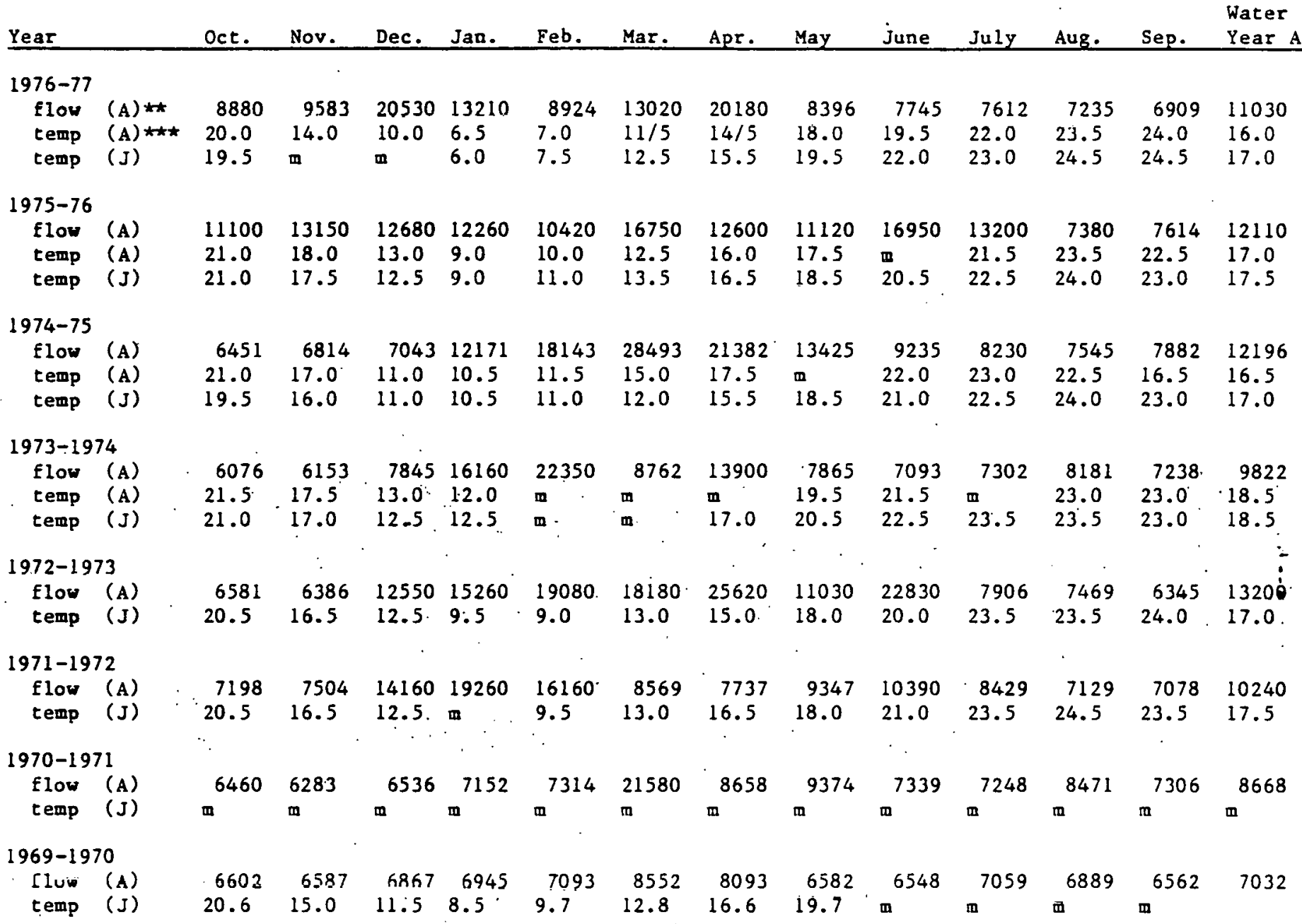

* Augusta measurements. are taken $0.2 \mathrm{mi}(0.3 \mathrm{~km})$ upstream from Butler Creek at mile 187.4 .

Jackson measurements are taken $1.4 \mathrm{mi}(2.3 \mathrm{~km})$ downstream from Upper Three Runs Creek at mile

156.8. References 19,30 .

** Flow values are given in cfs.

Temperature values are given in ${ }^{\circ} \mathrm{C}$. 
Appendix C.1. (cont)

\begin{tabular}{|c|c|c|c|c|c|c|c|c|c|c|c|c|c|c|}
\hline Year & Oct. & Nov. & Dec. & Jan. & Feb. & Mar. & Apr. & May & June & July & Aug. & Sep. & $\begin{array}{l}\text { Water } \\
\text { Year A }\end{array}$ & Ave. \\
\hline $\begin{array}{r}1968-1969 \\
\text { flow (A) } \\
\text { temp (J) }\end{array}$ & $\begin{array}{c}6649 \\
19.7\end{array}$ & $\begin{array}{c}6834 \\
15.0\end{array}$ & $\begin{array}{c}6469 \\
10.2\end{array}$ & $\begin{array}{l}10210 \\
7.8\end{array}$ & $\begin{array}{l}13590 \\
7.9\end{array}$ & $\begin{array}{l}11350 \\
9.8\end{array}$ & $\begin{array}{l}20800 \\
15.2\end{array}$ & $\begin{array}{l}13680 \\
19.3\end{array}$ & $\begin{array}{l}7370 \\
21.9\end{array}$ & $\begin{array}{c}6942 \\
23.2\end{array}$ & $\begin{array}{c}7128 \\
22.3\end{array}$ & $\begin{array}{l}7177 \\
21.9\end{array}$ & 9812 & \\
\hline $\begin{array}{r}1967-1968 \\
\text { flow (A) } \\
\text { temp (J) }\end{array}$ & $\begin{array}{c}6286 \\
19.9\end{array}$ & $\begin{array}{c}7593 \\
15.6\end{array}$ & $\begin{array}{l}15090 \\
12.7\end{array}$ & $\begin{array}{l}18440 \\
8.0\end{array}$ & $\begin{array}{l}7175 \\
8.2\end{array}$ & $\begin{array}{c}7199 \\
11.2\end{array}$ & $\begin{array}{l}7555 \\
15.1\end{array}$ & $\begin{array}{c}7620 \\
17.3\end{array}$ & $\begin{array}{l}9607 \\
20.0\end{array}$ & $\begin{array}{l}7366 \\
22.7\end{array}$ & $\begin{array}{l}7500 \\
23.4\end{array}$ & $\begin{array}{l}6809 \\
21.7\end{array}$ & 9043 & \\
\hline $\begin{array}{c}1966-1967 \\
\text { flow (A) } \\
\text { temp (J). }\end{array}$ & $\begin{array}{c}6478 \\
20.3\end{array}$ & $\begin{array}{l}6478 \\
17.0\end{array}$ & $\begin{array}{l}6795 \\
12.2\end{array}$ & $\begin{array}{l}8718 \\
9.5\end{array}$ & $\begin{array}{l}8439 \\
9.7\end{array}$ & $\begin{array}{c}9228 \\
13.1\end{array}$ & $\begin{array}{l}6870 \\
16.6\end{array}$ & $\begin{array}{l}7036 \\
18.4\end{array}$ & $\begin{array}{l}14440 \\
18.7\end{array}$ & $\begin{array}{l}8713 \\
22.2\end{array}$ & $\begin{array}{l}8625 \\
22.9\end{array}$ & $\begin{array}{l}8740 \\
21.7\end{array}$ & 8372 & \\
\hline $\begin{array}{r}1965-1966 \\
\text { flow (A) } \\
\text { temp (J) }\end{array}$ & $\begin{array}{c}7057 \\
20.2\end{array}$ & $\begin{array}{c}6958 \\
17.8\end{array}$ & $\begin{array}{l}7060 \\
13.7\end{array}$ & $\begin{array}{l}8783 \\
9.3\end{array}$ & $\begin{array}{l}13610 \\
8.3\end{array}$ & $\begin{array}{l}23610 \\
10.3\end{array}$ & $\begin{array}{c}7201 \\
15.5\end{array}$ & $\begin{array}{l}10480 \\
17.2\end{array}$ & $\begin{array}{c}9031 \\
20.0\end{array}$ & $\begin{array}{l}6830 \\
22.9\end{array}$ & $\begin{array}{c}6731 \\
22.9\end{array}$ & $\begin{array}{l}6896 \\
21.9\end{array}$ & 9509 & \\
\hline $\begin{array}{r}1964-1965 \\
\text { Ellow (A) } \\
\text { temp (J) }\end{array}$ & $\begin{array}{l}17740 \\
18.5\end{array}$ & $\begin{array}{l}10950 \\
16.4\end{array}$ & $\begin{array}{l}17670 \\
12.5\end{array}$ & $\begin{array}{l}17610 \\
9.8\end{array}$ & $\begin{array}{l}10120 \\
9.6\end{array}$ & $\begin{array}{l}17450 \\
10.5\end{array}$ & $\begin{array}{l}16370 \\
14.4\end{array}$ & $\begin{array}{c}9574 \\
18.4\end{array}$ & $\begin{array}{l}12760 \\
19.3\end{array}$ & $\begin{array}{l}7652 \\
21.8\end{array}$ & $\begin{array}{c}9027 \\
22.0\end{array}$ & $\begin{array}{c}7959 \\
22.1\end{array}$ & 12940 & $\because$ \\
\hline $\begin{array}{r}1963-1964 \\
\text { flow (A). } \\
\text { temp (J) }\end{array}$ & $\begin{array}{l}6559 \\
20.1\end{array}$ & $\begin{array}{l}6826 \\
16.4\end{array}$ & $\begin{array}{l}9818 \\
9.6\end{array}$ & $\begin{array}{l}16360 \\
7.1\end{array}$ & $\begin{array}{l}16720 \\
7.3\end{array}$ & $\begin{array}{l}27510 \\
12.0\end{array}$ & $\begin{array}{l}43850 \\
14.1\end{array}$ & $\begin{array}{l}27050 \\
17.7\end{array}$ & $\begin{array}{l}7143 \\
22.5\end{array}$ & $\begin{array}{l}10970 \\
21.9\end{array}$ & $\begin{array}{l}11900 \\
22.6\end{array}$ & $\begin{array}{l}14480 \\
22.3\end{array}$ & $\begin{array}{c}\vdots \\
16580\end{array}$ & - \\
\hline $\begin{array}{r}1962-1963 \\
\text { flow (A) } \\
\text { temp (J) }\end{array}$ & $\begin{array}{l}5960 \\
20.0\end{array}$ & $\begin{array}{l}5852 \\
15.1\end{array}$ & $\begin{array}{l}.5865 \\
10.5\end{array}$ & $\begin{array}{l}9178 \\
8.4\end{array}$ & $\begin{array}{l}9885 \\
7: 5\end{array}$ & $\begin{array}{l}18460 \\
11.0\end{array}$ & $\begin{array}{c}7675 \\
16.7\end{array}$ & $\begin{array}{l}14900 \\
17.5\end{array}$ & $\begin{array}{l}10090 \\
20.8\end{array}$ & $\begin{array}{l}11220 \\
22.4\end{array}$ & $\begin{array}{l}7875 \\
23.6\end{array}$ & $\begin{array}{l}7488 \\
21.8\end{array}$ & 9554 & \\
\hline $\begin{array}{r}1961-1962 \\
\text { flow (A) } \\
\text { temp (J) }\end{array}$ & $\begin{array}{l}5680 \\
19.6\end{array}$ & $\begin{array}{c}5537 \\
17.8\end{array}$ & $\begin{array}{l}12700 \\
12.7\end{array}$ & $\begin{array}{l}14960 \\
8.6\end{array}$ & $\begin{array}{l}9978 \\
10.2\end{array}$ & $\begin{array}{l}13180 \\
10.7\end{array}$ & $\begin{array}{l}15420 \\
14.1\end{array}$ & $\begin{array}{c}7963 \\
20.2\end{array}$ & $\begin{array}{l}8190 \\
21.5\end{array}$ & $\begin{array}{c}5676 \\
23.8\end{array}$ & $\begin{array}{l}5992 \\
23.7\end{array}$ & $\begin{array}{l}6050 \\
22.5\end{array}$ & 9276 & \\
\hline $\begin{array}{r}1960-1961 \\
\text { flow (A) } \\
\text { temp (J) }\end{array}$ & $\begin{array}{l}6514 \\
22.0\end{array}$ & $\begin{array}{l}5867 \\
16.5\end{array}$ & $\begin{array}{c}5943 \\
10.3\end{array}$ & $\begin{array}{l}6198 \\
8.4\end{array}$ & $\begin{array}{l}995 i \\
9.3\end{array}$ & $\begin{array}{l}11980 \\
12.7\end{array}$ & $\begin{array}{l}21770 \\
14.4\end{array}$ & $\begin{array}{c}7425 \\
19.5\end{array}$ & $\begin{array}{l}6783 \\
22.1\end{array}$ & $\begin{array}{c}8840 \\
22.5\end{array}$ & $\begin{array}{c}7700 \\
22.9\end{array}$ & $\begin{array}{l}7835 \\
22.9\end{array}$ & 8873 & \\
\hline
\end{tabular}

* Augusta measurements are taken $0.2 \mathrm{mi}(0.3 \mathrm{~km})$ upstream from Butler Creek at mile 187.4. Jackson measurements are taken $1.4 \mathrm{mi}(2.3 \mathrm{~km})$ downstream Erom Upper Three Runs Creek at mile 156.8. References 19,30 .

$\star \star$ Flow values are given in $\mathrm{cfs}$.

*** Temperature values are given in ${ }^{\circ} \mathrm{C}$. 
Appendix $C .1 .(\operatorname{con} t)$

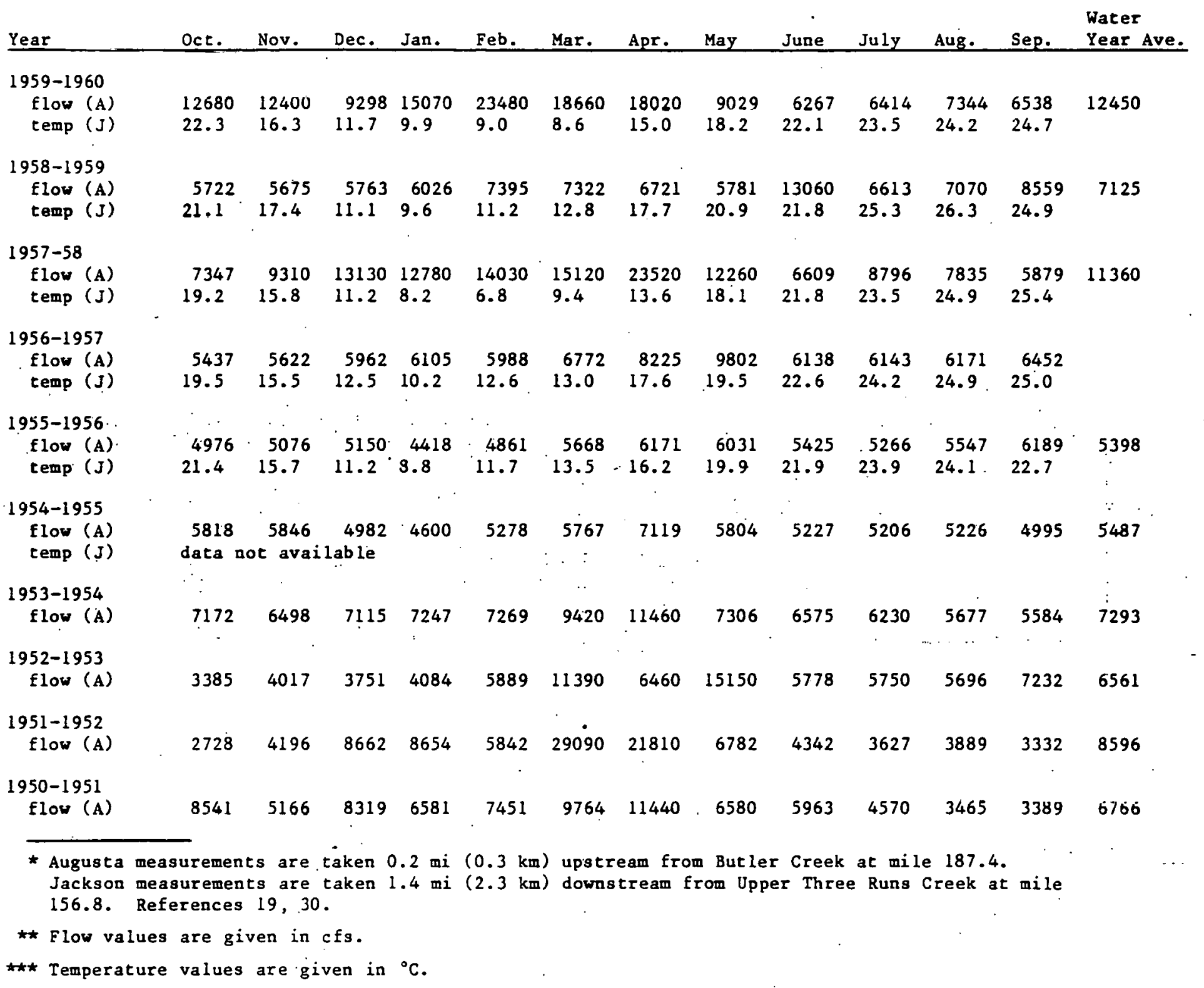


Appendix C.2. Savannah River Daily Flow at Augusta during the Academy of Natural Sciences of Philadelphia Surveys*

\begin{tabular}{|c|c|c|c|c|c|}
\hline Survey & Date & $\begin{array}{l}\text { F low } \\
\text { (cfs) }\end{array}$ & Survey & Date & F low \\
\hline
\end{tabular}

1. 1951: Jun. 256430

$26 \quad 6830$

$27 \quad 6230$

$28 \quad 5640$

$29 \quad 5360$

$30 \quad 5080$

Jul. 15260

25840

38080

46030

$5 \quad 5550$

$6 \quad 5640$

$7 \quad 5460$

85360

95460

10. 4900

114620

124100

$13 \quad 3580$

$14 \quad 3580$

2. 1951: Oct. 152360

$16 \quad 2280$

$17 \quad 1960$

$18 \quad 1770$

193250

20. 2170

2.1 1770

$22 \quad 1830$

$23 \quad 1890$

$24 \quad 1960$

$25 \quad 2150$

$26 \quad 2860$

$27 \quad 3420$

$28 \cdot 3670$

293840

30.3260

312860
3. 1952: Jan. 912800

$10 \quad 11600$

$11 \quad 10500$

129990

139510

$14 \quad 11400$

$15 \quad 13200$

$16 \quad 8320$

$17 \quad 4980$

$18 \quad 4540$

$19 \quad 5170$

$20 \quad 4360$

$21 \quad 5410$

$22 \quad 5040$

$23 \quad 5030$

$24 \quad 6930$

$25 \quad 5360$

$26 \quad 5080$

$27 \quad 4980$

$28 \quad 5260$

$29 \quad 6730$

$30 \quad 6730$

$31 \quad 57.40$

* Reference 19 
$\therefore$ Appendix C.2. (cont)

Discharge at Augusta (cfs)

- Survey Date Discharge Survey Date Discharge Survey Date charge

4. 1952: May 59990

69990

79270

$8 \quad 9270$

$9 \quad 9870$

$10 \quad 8030$

117590

128360

137480

147590

$15 \quad 6310$

16.4540

174360

184360

194540

$20 \quad 4900$

$21 \quad 4620$

$22 \quad 4540$

5. 1954: Aug 15 5460

$16 \quad 5550$

$17 \quad 5640$

$18 \quad 5640$

195640

$20 \quad 5640$

$21 \quad 5640$

$22 \quad 5640$

$23 \quad 5640$

$24 \quad 5550$

$25 \cdot 5550$

$26 \quad 5550$

$27 \quad 5640$

$28 \quad 5840$

$29 \quad 5740$

$30 \quad 5740$
6. 1955: Aug $24 \quad 5170$

$25 \quad 5080$

$26 \quad 4900$

$27 \quad 4900$

$28 \quad 4900$

$29 \quad 5260$

$30 \quad 5170$

$31 \quad 4980$

Sept 14900

24980

35460

44980

54980

- 65170

$7 \quad 5170$

7. 1956: May 64980

$7 \quad 5910$

87100

97260

$10 \quad 6630$

115930

125840

$13 \quad 5170$

146420

156790

$16 \quad 5930$

175260

185080

195840

$20 \quad 5360$

$21 \quad 6260$

$22 \quad 7590$
8. 1960: May 235570

$24 \quad 6010$

$25 \quad 6890$

$26 \quad 6010$

$27 \quad 6890$

$28 \quad 5900$

$29 \quad 5790$

$30 \quad 5790$

$31 \quad 6120$

June 17880

27550

$3 \quad 7770$

46120 .

9. 1960: Aug 31 7990

Sept 17990

28100

36010

45790

$5 \quad 5790$

$6 \quad 5790$

$7 \quad 6560$

87770

97220

$10 \quad 6120$

115900

125790

135900

$14 \quad 6670$

- $15 \quad 7220$ 
Appendix C.2. (cont)

Discharge at Augusta (cfs)

Survey Date Discharge Survey Date Discharge Survey Date charge

10. 1965: May 306550

$31 \quad 6780$

June 16960

26900

$3 \quad 6640$

4.6620

56600

$6 \quad 6560$

$7 \quad 6530$

87070

13. 1968 Aug $24 \quad 8230$

16. 1976: Aug 106900

$25 \quad 6900$

117430

$26 \quad 6870$

127650

$27 \quad 7040$

$13 \quad 7630$

$28 \quad 7100$

147850

297300

$15 \quad 7640$

$30 \quad 7770$

$16 \quad 6930$

11. 1965: Sept 216460

$31 \quad 7520$

Sept $1 \quad 6890$

26810

$22 \quad 6530$

$23 \quad 7240$

$24 \quad 7120$

$25 \quad 6900$

$26 \quad 6650$

$27 \quad 6580$

$28 \quad 6490$

297150

, $30 \quad 6890$

12. 1968: May 276750

28.6670

296650

$30 \quad 6650$

$31 \quad 6700$

June 16480

26730

36860

$4 \quad 6840$

$5 \quad 6570$

14. 1972: May 229610

2314700

24. 17100

2516500

$26 \quad 13700$

$27 \quad 9940$

$28 \quad 7440$

$29 \quad 7320$

$30 \quad 7250$

$31 \quad 7310$

June 17530

27500

15. 1972: Sept 136850

147020

159170

167520

$17 \quad 7110$

$18 \quad 6970$

196660

207060

217090

227190 


\section{DISTRIBUTION}

Copy

No.

1-7. DOE-SR

8-48. TIS File, SRL

49-53. Ruth Patrick, Academy of Natural Sciences, Philadelphia

54. John W. Gissendanner, U.S. Department of the Interior Geological Survey, Water Resources Division

55. J. Wayne Wiltz, Georgia Power Company Environmental Affairs Center

56. Barton C. Marcy, NUS Corporation

57. William E. Wisenbaker, Jr., DOE-SR

58. Elizabeth C. Goodson, DOE-SR

59. Robert W. McFarlane, McFarlane \& Associates

60. Harold Roberts, U.S. Army Corps of Engineers, Savannah District

61. Gary S. Hoover, South Carolina Department of Health and Environmental Control, Industrial \& Agricultural Wastes Water Division

62-297. DOE-TIC (for distribution under TID-4500 Category UC-11) 